\title{
ANÁLISE DA EVOLUÇÃO DO USO E OCUPAÇÃO DO SOLO NA UGRHI-11 E AVALIAÇÃO DE CENÁRIOS FUTUROS EM FUNÇÃO DE PROCESSOS EROSIVOS E DE MOVIMENTOS DE MASSA UTILIZANDO TÉCNICAS DE GEOPROCESSAMENTO
}

Fabrício Bau Dalmas

Orientador: Prof. Dr. Arlei Benedito Macedo

TESE DE DOUTORAMENTO

Programa de Pós-Graduação em Recursos Minerais e Hidrogeologia

São Paulo 
Ficha catalográfica preparada pelo Serviço de Biblioteca e Documentação do Instituto de Geociências da Universidade de São Paulo

Dalmas, Fabrício Bau

Análise da evolução do uso e ocupação do solo na UGRHI-11 e avaliação de cenários futuros em função de processos erosivos e de movimentos de massa utilizando técnicas de geoprocessamento / Fabrício Bau Dalmas. - São Paulo, 2013. $147 \mathrm{p}: \mathrm{il}$.

Tese (Doutorado) : IGc/USP

Orient.: Macedo, Arlei Benedito

1. Geotecnologias 2. Markov 3 Classificação não supervisionada 4.Bacia do Ribeira do Iguape I. Título 


\section{AGRADECIMENTOS}

Agradeço aos meus pais, Cyro José Dalmas e Elourdes Maria Bau Dalmas por terem sempre acreditado em mim. Aos meus irmãos, Sandro Bau Dalmas e Lissandra Bau Dalmas pelas palavras de motivação. Ao grande patriarca da família, meu avô Celeste Dalmas e a minha avó, Luisa Dalmas (in memoriam).

À Joana Bezerra da Costa, minha namorada e grande incentivadora, sua companhia foi essencial. Também agradeço a minha sogra, Luisa Bezerra; aos cunhados Ana Maria e Júnior; e ao filho de minha namorada, Vitor.

À Coordenação de Aperfeiçoamento de Pessoal de Nível Superior (CAPES), pela concessão da bolsa durante o doutorado. Ao Programa de Pós-Graduação em Recursos Minerais e Hidrogeologia e ao Departamento de Geologia Sedimentar e Ambiental do IGcUSP.

Aos colegas da sala de pesquisa - 105, Alexandre Santos, Carlos Carrasco, Joan da Cruz Rodrigues e Sidney Schaberle Goveia, pela constante ajuda. Às colegas de PósGraduação Daniela Gamito e Cibele Hummel do Amaral.

Aos colegas da Universidade Federal do Mato Grosso do Sul, Prof. Antônio Conceição Paranhos Filho (Toni) e a doutoranda Ana Paula Garcia.

Agradeço pelo apoio recebido pelos integrantes do Sistema de Informações Geográficas da Bacia do Ribeira de Iguape e Litoral Sul: Fábio Rodrigo de Oliveira, Gilberto Cugler, Alex Santos, e Lays Dias.

Ao amigo Marcelo da Silva, pelos momentos de discussão, sempre muito enriquecedores. 
Aos professores Teodoro Isnard Ribeiro de Almeida, por sua dedicação. Ao Prof. Marcelo Rocha, pelas constantes e importantes discussões. Ao Administrador do Laboratório de Informática Geológica, Antônio Tadashi Kikuda, pelo auxílio e pela amizade. Aos funcionários da Seção Gráfica do IGc-USP, sempre muito atenciosos.

Aos pesquisadores José Ojeda Zújar e Pablo Freire, professores no Departamento de Geografia Física e Análises Geográficas Regionais da Universidade de Sevilla, que auxiliaram-me durante meu estágio no Programa Institucional de Bolsas de Doutorado no Exterior da Coordenação de Aperfeiçoamento de Pessoal de Nível Superior (PSDE/CAPES).

Finalizando, ao grande responsável pelo êxito deste trabalho. Uma pessoa que confiou em mim, que está ao meu lado desde o início co meu mestrado, que investiu e até insistiu muito na minha formação e com quem aprendo algo a mais a cada dia, meu amigo e orientador, Prof. Arlei Benedito Macedo.

Outro agradecimento especial à esposa do meu orientador, Anna Schulz, também mais do que uma amiga, uma grande conselheira e grande revisora gramatical desta tese. 
À minha avó (in memoriam), que sempre me tratou com um carinho especial. Ao meu avô, que até hoje, passados os cem anos de vida, continua instigando-me a nunca parar de buscar conhecimento. 


\section{RESUMO}

Dalmas, F. B. Análise da evolução do uso e ocupação do solo na UGRHI-11 e avaliação de cenários futuros em função de processos erosivos e de movimentos de massa utilizando técnicas de geoprocessamento. 2013. p. 147. Tese (Doutorado) - Instituto de Geociências, Universidade de São Paulo, São Paulo.

A Unidade de Gerenciamento de Recursos Hídricos n 11 (UGRHI 11) correspondente à Bacia Hidrográfica do Rio Ribeira de Iguape e Litoral Sul e pequenas bacias litorâneas adjacentes, se localiza ao sul do Estado de São Paulo. Esta unidade apresenta grande diversidade de ambientes terrestres e aquáticos, envolvendo extensas áreas de relevo serrano, com fortes declividades e várzeas encaixadas e um setor composto por planícies costeiras, manguezais, terraços marinhos e fluviais. É uma região sensível não só nos aspectos da biodiversidade, mas também no âmbito dos processos geomorfológicos, pois se trata de ambiente extremamente propício aos desencadeamentos de processos erosivos de todos os tipos, bem como altamente susceptível a escorregamentos de encostas e rolamentos de blocos. O objetivo deste trabalho foi desenvolver possíveis cenários futuros de uso e ocupação do solo, baseando-se na evolução deste uso durante 24 anos (1986 - 2010) e prever cenários para 2025, analisando o crescimento ou regressão das classes de uso e ocupação do solo e considerando nessa evolução temporal a ação de agentes modificadores do terreno. A primeira fase da metodologia foi composta pela elaboração de mapas de suscetibilidade a erosão e movimentos de massa utilizando os métodos RUSLE e Combinação Linear Ponderada, respectivamente. Posteriormente, através de classificação não supervisionada, elaborou-se mapas de uso e ocupação do solo da UGRHI-11 referente a 1986, 1999 e 2010. Através da aplicação das técnicas de Titus e Narayanan, Pfeffer, Ramhstorf e modelo do Intergovernmental Panel on Climate Change, no ArcGIS, calculou-se a vulnerabilidade do Complexo Estuarino-Lagunar de Cananéia-Iguape a um potencial aumento do nível do mar em 2025, 2050 e 2100. Os mapas de uso e ocupação do solo de 1986, 1999 e 2010, aliados aos mapas de suscetibilidade à erosão e movimentos de massa foram utilizados nas Cadeias de Markov, acopladas a um algoritmo de Autômato Celular, no IDRISI Taiga, para a simulação do uso e ocupação do solo da UGRHI-11, em 2025. Na última fase da metodologia, 
foram avaliadas as classes de uso e ocupação do solo que possivelmente serão afetadas por um evento de máxima preamar, em 2025. Como conclusão, a utilização de diferentes tipos de ferramentas das geotecnologias mostrou-se eficaz e mesmo integrando diferentes "frentes" de trabalho: mapeamento de áreas suscetíveis a movimentos de massa e erosão; mapeamento do uso e cobertura do solo da UGRHI-11 e simulação do cenário de 2025; além do cálculo da vulnerabilidade a um potencial aumento do nível do mar (2025, 2050 e 2100). Foi possível agregar todos estes produtos e elaborar o produto final, a quantificação das áreas das classes de uso e ocupação do solo do Complexo Estuarino-Lagunar de Iguape-Cananéia, em 2025.

Palavras-chave: Geotecnologias; Markov; Classificação não supervisionada; Bacia do Ribeira de Iguape. 


\section{ABSTRACT}

Dalmas, F. B. Análise da evolução do uso e ocupação do solo na UGRHI-11 e avaliação de cenários futuros em função de processos erosivos e de movimentos de massa utilizando técnicas de geoprocessamento. 2013. p. 147. Tese (Doutorado) - Instituto de Geociências, Universidade de São Paulo, São Paulo.

The water resources managing unit 11 (UGRHI-11) corresponds to Ribeira de Iguape river Drainage Basin and São Paulo State Southern Coast and small adjacent basins is located in south of São Paulo State. This unit presents great diversity of terrestrial and aquatic environments, big areas of dissected relief with high slopes and lowland and a sector consists of coastal plains, mangroves, marine and river terraces. It is a region sensible not only to biodiversity aspects but included to geomorphology process because it's an environment conducive to erosion and landslides processes. The goal of this search was develop possible scenarios of soil use and occupation based in the evolution during 24 years (1986 - 2010) and forecast scenarios to 2025, analyzing the growth or retraction of classes of soil use and occupation and considering in this temporal evolution the actions of terrain modifiers. In the first step of methodology was developed the maps of susceptibility to erosion and landslides with the use of RUSLE and Weight Linear Combination. In the next step by using unsupervised classification were prepared maps of soil use and occupation of UGRHI-11 relative to years 1986, 1999 and 2010. The methods of Titus y Narayanan, Pfeffer, Ramhstorf and Intergovernmental Panel on Climate Change model were processed in the ArcGIS 10 program with the goal of calculate the vulnerability of Complexo Estuarino-Lagunar de Cananéia-Iguape to a potential increase in sea level in 2025, 2050 and 2100. The maps of soil use and occupation of 1986, 1999 and 2010 allies to the maps of erosion and landslides were used in Markov Chain Analysis and Cellular Automata in the IDRISI Taiga to simulation of classes of soil use and occupation of UGRHI-11 in 2025. In the last step were evaluated the classes of soil use and occupation that will be affected by one possible high tide event in 2025. The conclusion is that the application of differents kinds of geotecnology tools was effective even integrating different jobs: mapping of susceptible areas to erosion and landslides; mapping of soil use and simulation of scenarios of 2025; beyond the calculation of vulnerability to a potential increase in sea level in $(2025,2050$ and 2100). It was possible to 
aggregate all these products and to elaborate the last product the quantification of areas of classes of soil use and occupation of Complexo Estuarino-Lagunar de Iguape-Cananéia, in 2025 .

Keywords: Geotechnology; Markov; Unsupervised classification; Ribeira de Iguape Basin. 


\section{ÍNDICE}











4.2. Economia: atividades e potencialidades.......................................................... 11

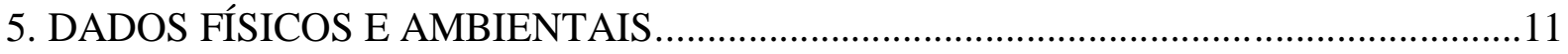

5.1. Processos geológicos: dinâmica superficial...................................................11







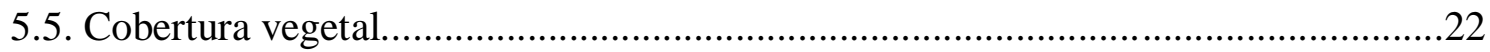



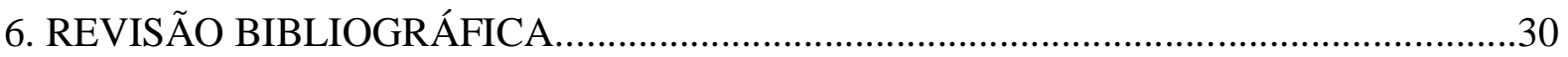

6.1. Suscetibilidade a erosão e escorregamentos no Vale do Ribeira do Iguape e Litoral

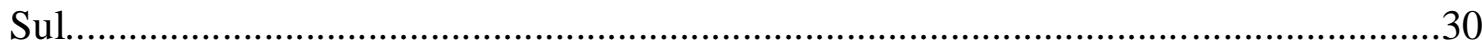

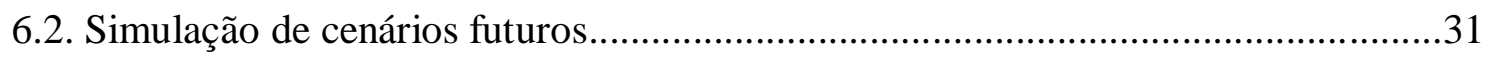





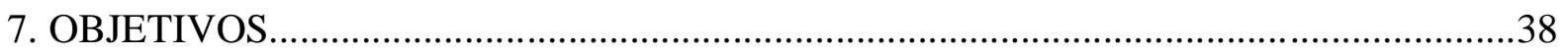





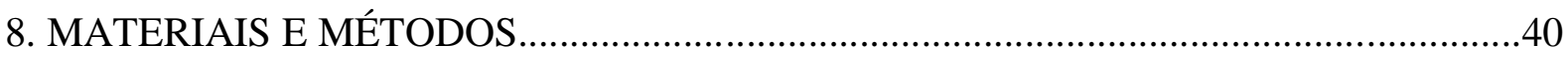


9. DESENVOLVIMENTO E AVALIAÇÃO DE UM MODELO DE PREVISÃO A EROSÃO E DESLIZAMENTO DE TERRA NO VALE DO RIBEIRA DO IGUAPE E LITORAL SUL DO ESTADO DE SÃO PAULO............................................................41

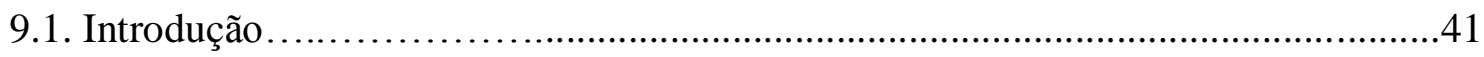

9.2 Criação do mapa de vulnerabilidade a processos erosivos....................................41

9.2.1. Erosividade da chuva..............................................44

9.2.2. Erodibilidade do solo.....................................................

9.2.3. Comprimento e grau de declive....................................45

9.2.4. Fatores de uso e manejo do solo (C) e práticas conservacionistas...............46

9.3 Criação do mapa de suscetibilidade a deslizamentos...............................46

9.3.1. Mapa de declividade.............................................46

9.3.2. Mapa litológico...............................................47

9.3.3. Mapa pedológico.......................................................47

9.3.4. Mapa de uso e ocupação do solo............................................47

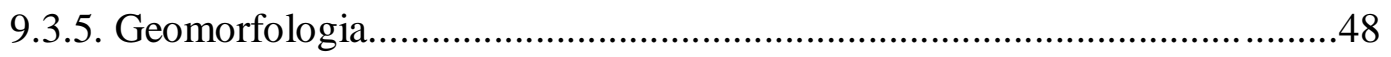

9.3.6. Erosividade da chuva.................................................. 48

9.4. Padronização dos critérios ..............................................48

9.5. Ponderação dos critérios...............................................48



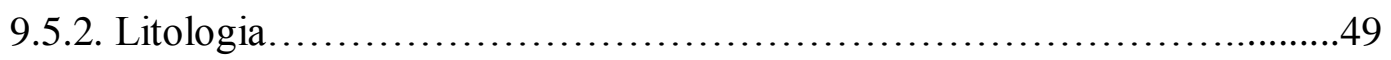

9.5.3. Uso e ocupação do solo.........................................50

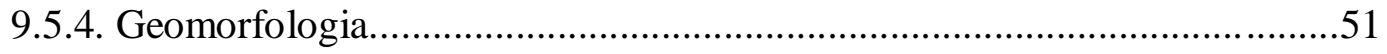

9.5.5. Erosividade das chuvas..............................................51




9.7. Resultados.

9.7.1. Mapa de suscetibilidade a erosão..........................................................53

9.7.2. Mapa de suscetibilidade a movimentos de massa....................................55

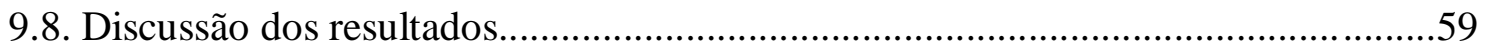

10. EVOLUÇÃO DO USO DO SOLO NO VALE DO RIBEIRA DE IGUAPE E LITORAL





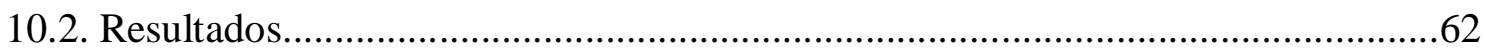

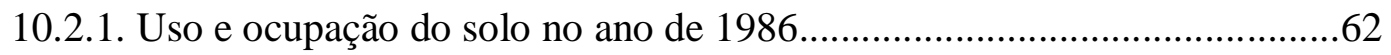

12.2.2. Uso e ocupação do solo no ano de 1999 .................................................64



10.2.4. Uso e ocupação do solo entre os anos do estudo......................................68

10.3. Discussão. .69

11. CÁlCULO DA SUSCETIBILIDADE A UM POTENCIAL AUMENTO NO NÍVEL DO MAR NO COMPLEXO ESTUARINO-LAGUNAR DE IGUAPECANANÉIA .73

11.1. Introdução .73

11.2. Objetivos. .74

11.3. Área de estudo .74

11.4. Materiais e métodos .75

11.4.1. Elaboração do modelo digital de terreno .75

11.4.2. Cálculo da tendência local de variação do nível médio do mar, com dados do marégrafo de cananéia. .76 
11.4.3. Valor máximo da preia-mar. .77



11.4.5. Modelo de pfeffer........................................................................... 80



11.4.7. Modelo intergovernmental panel on climate change (IPCC)



11.5.1. Aplicação do modelo de Titus e Narayan...................................................83

11.5.1.1. Probabilidades do modelo e elaboração dos mapas........................84

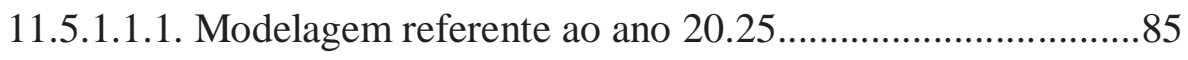

11.5.1.1.2. Modelagem referente ao ano 2050..................................86

11.5.1.1.3. Modelagem referente ao ano 2100...............................89

11.5.2. Aplicação do modelo de Pfeffer............................................................. 90

11.5.2.1. Modelagem de Pfeffer referente ao ano 2100.............................92

11.5.3. Aplicação do modelo de Ramhstorf...........................................................93

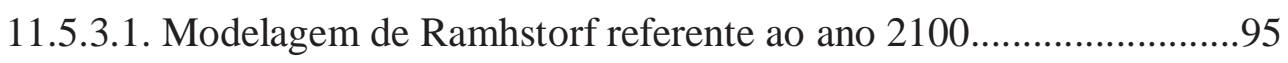

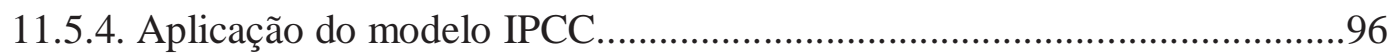

11.5.4.1. Modelagem de IPCC referente ao ano 2100...............................98

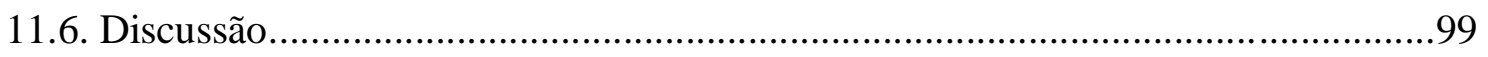

12. APLICAÇÃO DE GEOTECNOLOGIAS NA ELABORAÇÃO DE CENÁRIOS FUTUROS DE USO DO SOLO NO VALE DO RIBEIRA DE IGUAPE E LITORAL SUL DO ESTADO DE SÃO PAULO, PARA 2025 .................................................................. 101

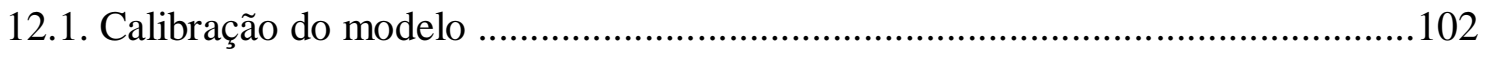

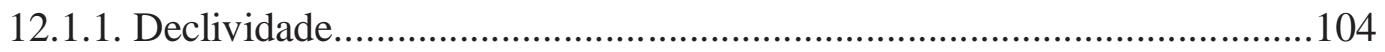


12.1.2. Influência das vias de acesso

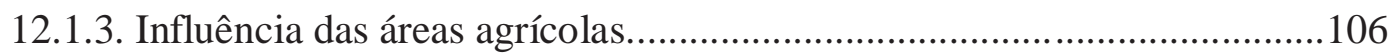

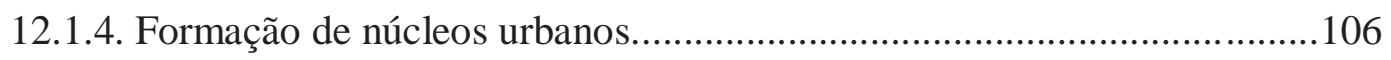

12.1.5. Áreas suscetíveis a movimentos de massa...............................................107

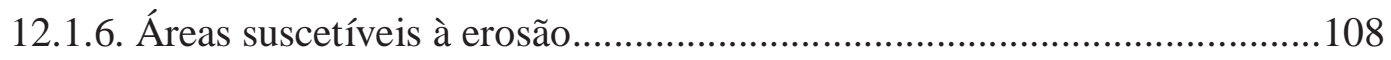

12.1.7. Vegetação arbórea densa como área de restrição...................................109

12.2. Atribuição de pesos aos agentes modificadores..................................................110

12.3. Criação do mapa final com a sobreposição dos agentes modificadores...............112

12.3.1. Simulação do cenário que represente as classes de uso e cobertura do solo em 2010 .

12.3.2. Simulação do cenário que represente as classes de uso e cobertura do solo em 2025.

12.3.2.1. Simulação do cenário que represente as classes de uso e cobertura do solo em 2025

12.4. Discussões.

13. CLASSES DE USO E COBERTURA DO SOLO ATINGIDAS POR UM POTENCIAL



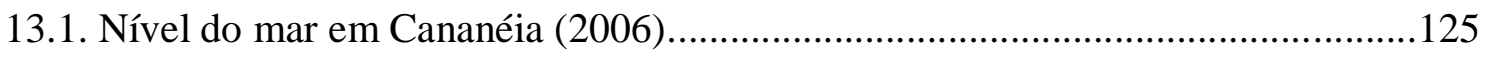



13.3. Sobreposição dos resultados de Titus e Narayanan sobre o mapa de 2025 .

13.3. Discussões 130

14. CONCLUSÕES 131

15. REFERÊNCIAS BIBLIOGRÁFICAS. 134 


\section{LISTA DE FIGURAS}

Figura 1. Índices de vegetação natural remanescente dos municípios do Estado de São Paulo.

Figura 2. Índices de vegetação natural remanescente nas diferentes UGRHI do Estado de São Paulo

Figura 3. Índices de vegetação natural remanescente em Áreas de Preservação Permanente do Estado de São Paulo

Figura 4. Localização da Bacia Hidrográfica do Ribeira de Iguape e Litoral

Sul 07

Figura 5. Complexo Estuarino-Lagunar de Iguape-Cananéia. 08

Figura 6. Mapa litológico do Vale do Ribeira do Iguape e Litoral Sul .13

Figura 7. Mapa geomorfológico do Vale do Ribeira do Iguape e Litoral Sul. 15

Figura 8. Mapa pedológico do Vale do Ribeira do Iguape e Litoral Sul..... 16

Figura 9. Mapa de declividade do Vale do Ribeira do Iguape e Litoral sul...... .29

Figura 10. Modelo Numérico de Terreno do Vale do Ribeira do Iguape e Litoral sul. 30

Figura 11. Mapa de suscetibilidade a erosão .54

Figura 12. Mapa de suscetibilidade a movimento de massa. .56

Figura 13. Área com movimento de massa na cidade de Barra do Turvo 57

Figura 14. Área com movimento de massa na cidade de Cajati. 58

Figura 15. Área com movimento de massa na cidade de Eldorado 59

Figura 16. Mapa de uso e ocupação do solo da UGRHI-11, em 1986. .63

Figura 17. Uso e ocupação do solo da UGRHI-11, em 1986. .64

Figura 18. Mapa de uso e ocupação do solo da UGRHI-11, em 1999. .65 
Figura 19. Uso e ocupação do solo da UGRHI-11, em 1999. .66

Figura 20. Mapa de uso e ocupação do solo da UGRHI-11, em 2010. .67

Figura 21. Uso e ocupação do solo da UGRHI-11, em 2010 .68

Figura 22. Evolução da classe "área urbana" .69

Figura 23. Evolução da classe "corpo de água". 69

Figura 24. Evolução da classe "bananicultura". .70

Figura 25. Evolução da classe "vegetação arbórea densa". 70

Figura 26. Evolução da classe "vegetação de várzea ou campo sujo"..... .71

Figura 27. Evolução da classe "solo exposto" . .71

Figura 28. Área de estudo: Complexo Estuarino-Lagunar de Iguape-Cananéia. .75

Figura 29. Análise de regressão linear sobre os registros do marégrafo de Cananéia, referente ao período $1954-2006$.

Figura 30. Modelo de Titus e Narayan aplicado ao ano 2025 sobre as probabilidades de 99\%, $50 \%$ e $1 \%$ .85

Figura 31. Modelo de Titus e Narayan aplicado ao ano 2025 sobre as probabilidades de 99\%, $50 \%$ e $1 \%$. .86

Figura 32. Modelo de Titus e Narayan aplicado ao ano 2050 sobre as probabilidades de $99 \%$, $50 \%$ e $1 \%$

Figura 33. Modelo de Titus e Narayan aplicado ao ano 2050 sobre as probabilidades de $99 \%$, $50 \%$ e $1 \%$. .88

Figura 34. Modelo de Titus e Narayan aplicado ao ano 2100 sobre as probabilidades de 99\%, $50 \%$ e $1 \%$.

Figura 35. Modelo de Titus e Narayan aplicado ao ano 2100 sobre as probabilidades de 99\%, $50 \%$ e $1 \%$. .90

Figura 36. Modelo de Pfeffer aplicado ao ano 2100 aos Cenários 1, 2 e 3. .92 
Figura 37. Modelo de Pfeffer aplicado ao ano 2100 aos Cenários 1, 2 e 3

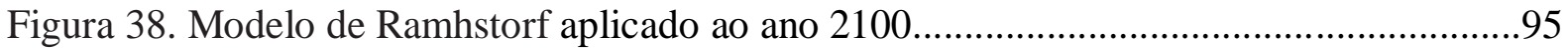

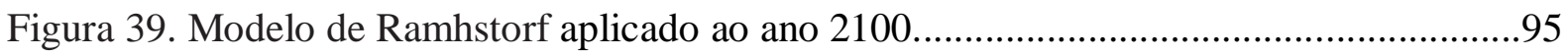

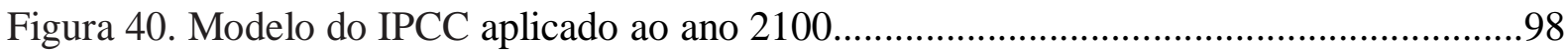

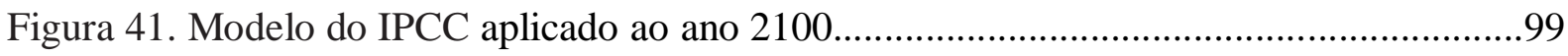

Figura 42. Projeção de todos os métodos para a máxima preia-mar em



Figura 43. Representação do método de calibração do modelo................................................103

Figura 44. Mapa de adequação do uso do solo terra a partir da declividade..........................104

Figura 45. Mapa de adequação do uso do solo terra a partir da malha viária.........................105

Figura 46. Mapa de adequação do uso do solo terra a partir das áreas agrícolas de 1999. 106

Figura 47. Mapa de adequação do uso do solo terra a partir das áreas urbanas de 1999. 107

Figura 48. Mapa de adequação do uso do solo terra a partir das áreas suscetíveis a movimentos de massa. 108

Figura 49. Mapa de adequação do uso do solo terra a partir das áreas suscetíveis a erosão

Figura 50. Mapa de restrição do uso do solo terra a partir da vegetação arbórea densa de 1999.

Figura 51. Mapa de restrição às classes de vegetação de várzea ou campo sujo, e solo exposto de 1999.

Figura 52. Mapa da simulação de uso e cobertura do solo para o ano 2010.

Figura 53. Mapa real (a) e simulado (b) de uso e cobertura do solo para o ano 2010

Figura 54. Intervalo de consistência do kappa. 
Figura 55. Representação do método de simulação do uso e cobertura do solo para 2025 .

Figura 56. Mapa da simulação de uso e cobertura do solo para o ano 2025

Figura 57. Uso e cobertura do solo da UGRHI-11, em 2025

Figura 58. Evolução temporal da área da classe "área urbana" entre 1986 a 2025

Figura 59. Evolução temporal da área da classe "corpo de água" entre 1986 a 2025 .

Figura 60. Evolução temporal da área da classe "banana" entre 1986 a 2025 .

Figura 61. Evolução temporal da área da classe "vegetação arbórea densa" entre 1986 a 2025 123

Figura 62. Evolução temporal da área da classe "vegetação de várzea ou campo sujo" entre 1986 a 2025

Figura 63. Evolução temporal da área da classe "vegetação de várzea ou campo sujo" entre 1986 a 2025

Figura 64. Limite do CECI sobreposto ao mapa de classes de uso e cobertura do solo da UGRHI-11, em 2025 126

Figura 65. Classes de uso e cobertura do solo do CECI, em 2025.

Fig. 66. Cenários de Titus e Narayanan sobrepostos ao mapa de uso e cobertura do solo em 2025 . 128 


\section{LISTA DE TABELAS}

Tabela 1. Áreas que tiveram aumento da vegetação natural entre 2000/01 e $2004 / 05$

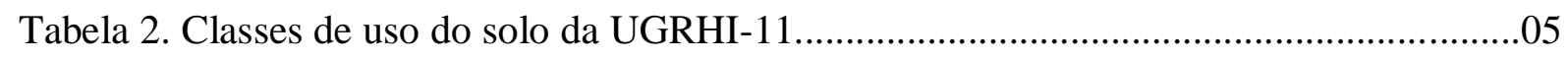

Tabela 3. Estatísticas Agrícolas, 1995/96............................................................................. 10

Tabela 4. Estatísticas Agrícolas, 2007/08............................................................................ 10

Tabela 5. Diferentes categorias de vegetação mapeadas e quantificadas nos períodos de 20002001 e 2004-2005, na Região Administrativa de Registro..

Tabela 6. Categorias de vegetação presente nos municípios da Região Administrativa de Registro.

Tabela 7. Categorias de vegetação presente nos municípios da Região Administrativa de Registro .28

Tabela 8. Valores de erodibilidade atribuídos às classes de solos. 45

Tabela 9. Valores de LS atribuídos às classes de declividade .45

Tabela 10. Valores de CP atribuídos às classes de uso do solo. .46

Tabela 11. Classes pedológicas e respectivos pesos . .49

Tabela 12. Classes litológicas e respectivos pesos

Tabela 13. Classes de cobertura do solo e respectivos pesos.

Tabela 14. Geomorfologia e respectivos pesos

Tabela 15. Áreas suscetíveis a movimentos de massa na UGRHI-11 55

Tabela 16. Suscetibilidade a movimentos de massa nas áreas inspecionadas 55

Tabela 17. Uso do solo nos anos estudados, em área $\left(\mathrm{km}^{2}\right)$ e porcentagem. 68

Tabela 18. Valores normalizados de variação do nível do mar (centímetros), onde já foi eliminada a componente global de subida no nível médio do mar durante o século 20.

Tabela 19. Resultado da aplicação da equação de Titus e Narayan para os anos de 2025, 2050 e 2100. 
Tabela 20. Resultado da soma entre os valores obtidos da aplicação da equação de Titus e Narayan e o valor médio do nível do mar em Cananéia (1990) para os anos de 2025, 2050 e 2100

Tabela 21. Resultado da soma entre os valores da Tabela 20 e máxima preia-mar, para os anos de 2025,2050 e 2100 .

Tabela 22. Área inundadas pela máxima preia-mar para os anos 2025, 2050 e 2100

Tabela 23. Resultado da Eq. 3

Tabela 24. Resultado da soma entre os valores obtidos da aplicação da equação de Pfeffer, nível médio em 1990 e a máxima preia-mar.

Tabela 25. Área inundadas pela máxima preia-mar, em 2100, dos Cenários de Pfeffer.

Tabela 26. Resultado da soma entre os valores obtidos da aplicação da equação de Ramhstorf (em centímetros).

Tabela 27. Resultado da soma entre os valores obtidos da aplicação da equação de Ramhstorf, nível médio em 1990 e a máxima preia-mar (em centímetros).

Tabela 28. Área inundadas pela máxima preia-mar, em 2100, dos Cenários de Ramhstorf (em $\mathrm{km}^{2}$ ).

Tabela 29. Resultado da soma entre os valores obtidos da aplicação da equação de IPCC, nível médio em 1990 e a máxima preia-mar (em centímetros).

Tabela 30. Área inundadas pela máxima preia-mar, em 2100, referente ao modelo do IPCC $\left(\mathrm{em} \mathrm{km}{ }^{2}\right)$

Tabela 31. Projeção de todos os métodos para a máxima preia-mar em 2100 100

Tabela 32. Intervalos de declividade, valores e classes de adequação de uso.

Tabela 33. Classes de uso e cobertura do solo participantes da Análise Multicritério 110

Tabela 34. Principais Componentes - Área urbana.

Tabela 35. Principais Componentes - Hidrografia. 
Tabela 36. Principais Componentes - Bananicultura.

Tabela 37. Principais Componentes - Vegetação arbórea densa.

Tabela 38. Principais Componentes - Vegetação várzea ou campo sujo

Tabela 39. Principais Componentes - Solo exposto.

Tabela 40. Áreas das classes de uso e ocupação do solo real e simulado para o ano 2010

Tabela 41. Áreas das classes de uso e ocupação do solo real e simulado para o ano 2025 .

Tabela 42. Áreas das classes de uso e cobertura do solo que, supostamente, poderiam ser inundadas por um evento de máxima preia-mar no ano 2025 129

Tabela 43. Classes de uso e cobertura do solo, supostamente, inundadas por um evento de máxima preia-mar no ano 2006.

Tabela 44. Percentagem de área inundada com dados registrados de 2006 e simulados para 2025 . 


\section{INTRODUÇÃO}

A Unidade de Gerenciamento de Recursos Hídricos n 11 (UGRHI 11) correspondente à Bacia Hidrográfica do Rio Ribeira de Iguape e Litoral Sul e pequenas bacias litorâneas adjacentes, se localiza ao sul do Estado de São Paulo, tendo o rio uma extensão aproximada de $260 \mathrm{~km}$, com uma testada de $140 \mathrm{~km}$ para o Oceano Atlântico. Esta unidade apresenta grande diversidade de ambientes terrestres e aquáticos, envolvendo extensas áreas de relevo serrano, com fortes declividades e várzeas encaixadas e um setor composto por planícies costeiras, manguezais, terraços marinhos e fluviais, com destaque para o complexo estuarinolagunar de Iguape-Cananéia (CBH-RB, 2008).

A bacia do Ribeira insere-se num relevo bastante dissecado e movimentado, alcançando altitude de 1.416 metros, com uma variação entre zero e 80 graus de declividade, pertencendo, em termos geomorfológicos, na sua maior parte, à Província Costeira, a qual se limita com o Planalto Atlântico através dos divisores das serras do Mar e de Paranapiacaba (Almeida, 1964; Ponçano et al., 1981).

Por estes motivos, no âmbito da fragilidade é uma região sensível não só nos aspectos da biodiversidade, mas também no âmbito dos processos geomorfológicos, pois se trata de ambiente extremamente propício aos desencadeamentos de processos erosivos de todos os tipos, bem como altamente susceptível a escorregamentos de encostas e rolamentos de blocos (CBH-RB, 2008). De acordo com um dos estudos desenvolvidos no presente trabalho, o Litoral Sul do Estado de São Paulo (inserido na UGRHI-11) é uma área suscetível a possíveis aumentos do nível do mar, nas próximas décadas.

O mais recente levantamento referente ao uso e ocupação do solo do Vale do Ribeira foi efetuado pelo Instituto Florestal da Secretaria do Meio Ambiente do Estado de São Paulo, decorrente do "Inventário Florestal da Vegetação Natural do Estado de São Paulo: Regiões Administrativas de São José dos Campos (Litoral), Baixada Santista e Registro”, organizado pelo Instituto Florestal do Estado de São Paulo, em 2007.

Este projeto do Instituto Florestal constitui uma sequiência das atividades que o Instituto Florestal tem desenvolvido, objetivando o mapeamento e a quantificação da vegetação do Estado, e também sua atualização de forma periódica. O monitoramento da atual área - Regiões Administrativas de São José dos Campos (Litoral), Baixada Santista e Registro foi efetuado através da comparação entre imagens, com as devidas fotointerpretações temáticas, tomadas em períodos distintos (2000-2001 e 2004-2005). O trabalho é composto por uma sequência dos levantamentos efetuados pelo Programa de Pesquisas em 
Caracterização, Conservação e Uso Sustentável da Biodiversidade - BIOTA/FAPESP: O Instituto Virtual da Biodiversidade, da Fundação de Amparo à Pesquisa do Estado de São Paulo, apresentando, também, a legenda dos tipos vegetacionais convertida para o sistema de classificação fisionômico-ecológico e hierárquico utilizado pelo Instituto Brasileiro de Geografia e Estatística - IBGE (Instituto Florestal, 2007).

Neste projeto do Instituto Florestal foram desenvolvidos mapas florestais dos municípios apresentando as diferentes categorias da vegetação natural e, menos detalhados, mapas com índices de vegetação natural remanescente do Estado de São Paulo (Figura 1), Índices de vegetação natural remanescente nas diferentes UGRHI (Figura 2) e Índices de vegetação natural remanescente em Áreas de Preservação Permanente (Figura 3).

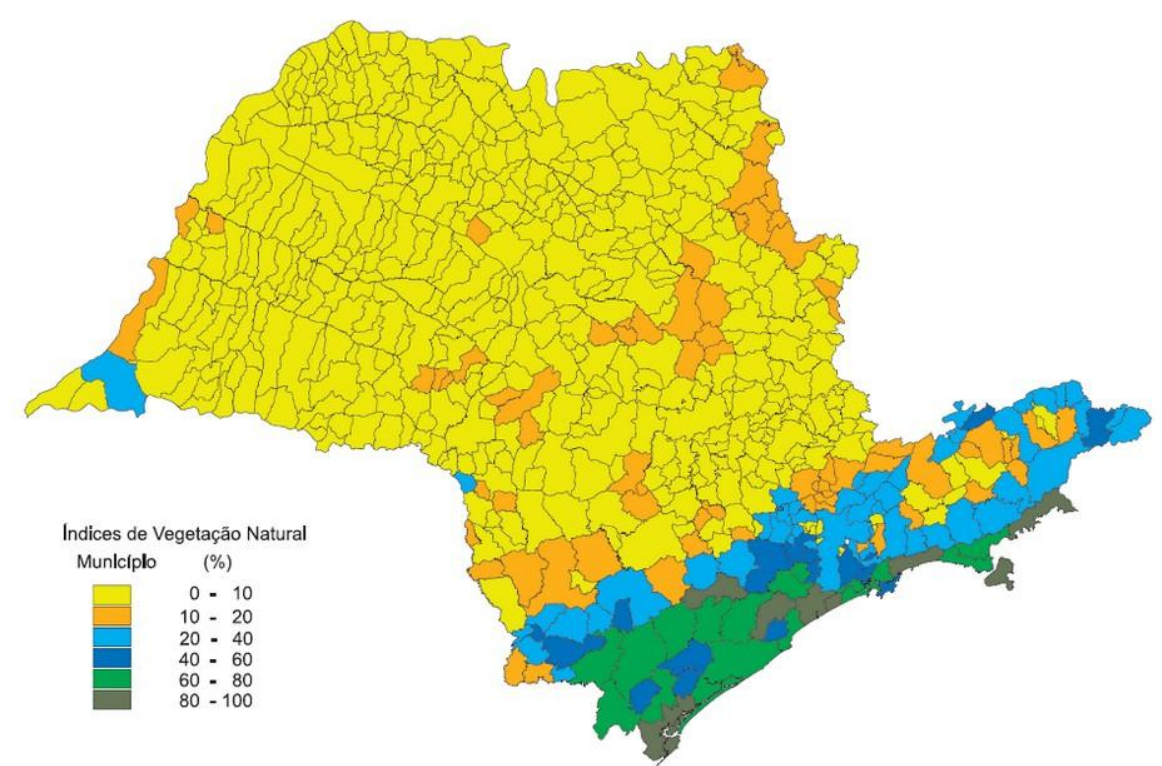

Figura 1. Índices de vegetação natural remanescente dos municípios do Estado de São Paulo, observadas as diferentes porcentagens de ocorrência. Fonte: Instituto Florestal, 2007. 


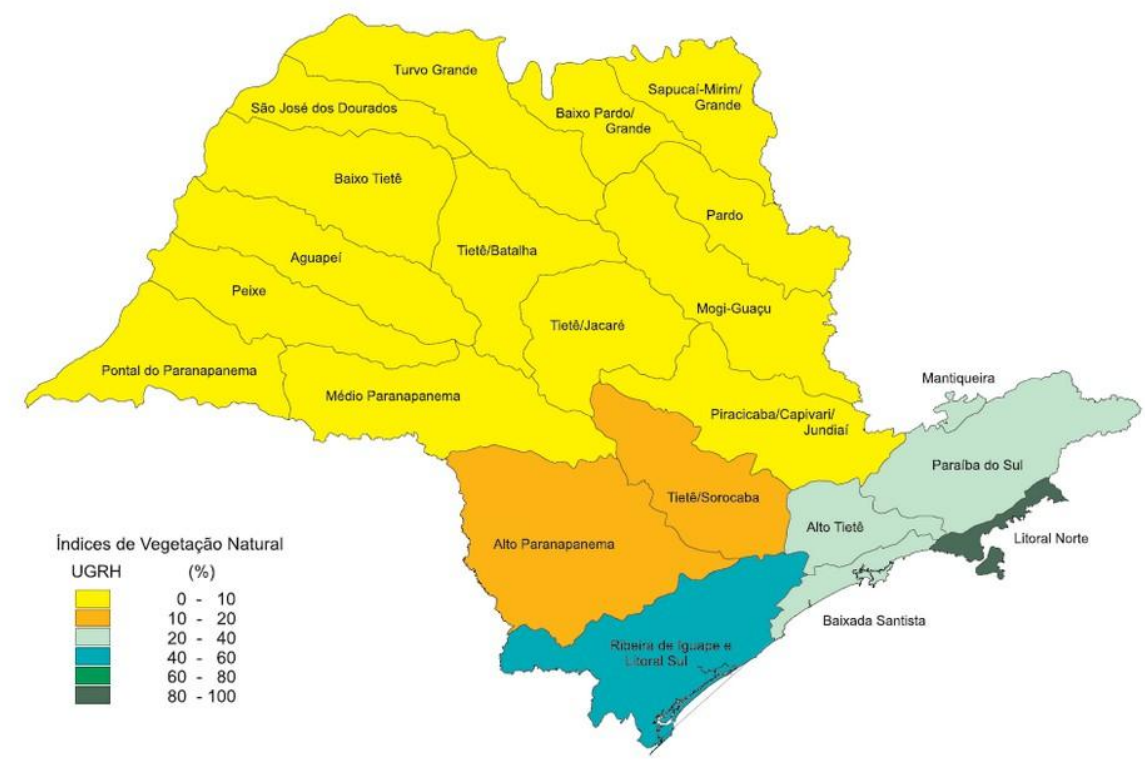

Figura 2. Índices de vegetação natural remanescente nas diferentes UGRHI do Estado de São Paulo, observadas as diferentes porcentagens de ocorrência. Fonte: Instituto Florestal, 2007.

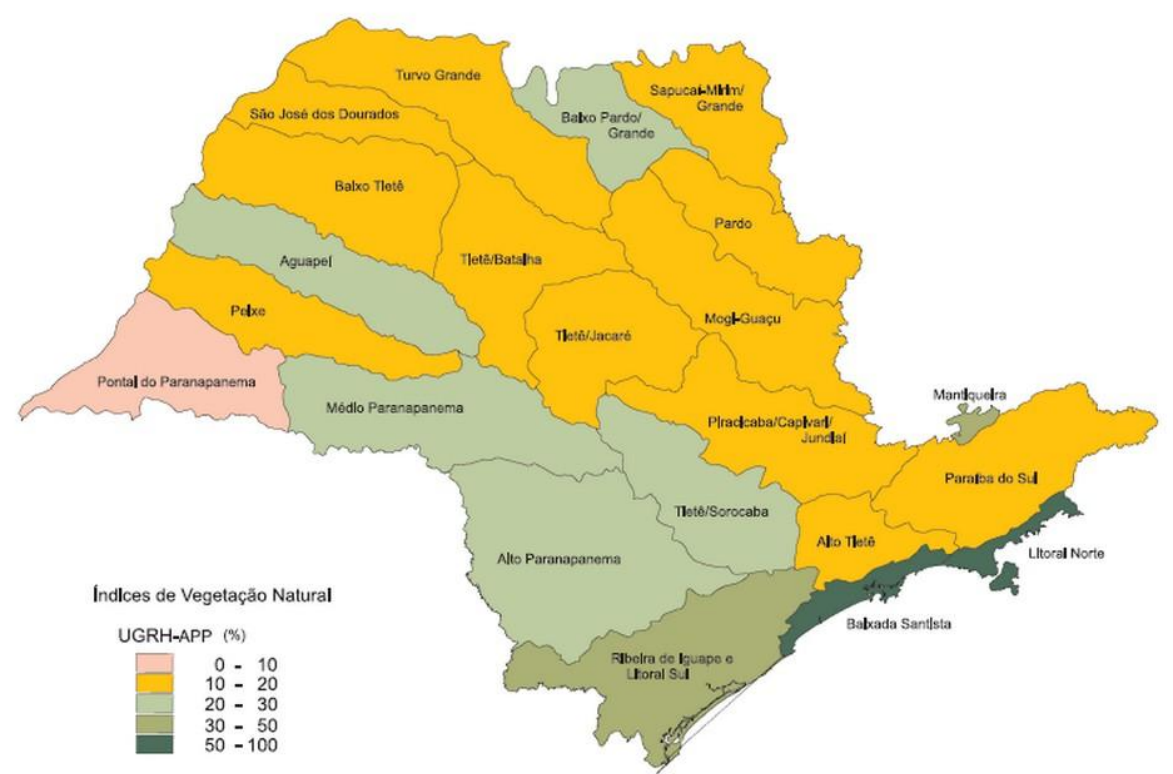

Figura 3. Índices de vegetação natural remanescente em Áreas de Preservação Permanente do Estado de São Paulo, observadas as diferentes porcentagens de ocorrência. Fonte: Instituto Florestal, 2007. 
As áreas vegetadas medidas pelo levantamento foram comparadas com os resultados de 2001, e as diferenças apresentadas na Tabela 1.

Tabela 1. Áreas que tiveram aumento da vegetação natural entre 2000-2001 e 2004-2005.

\begin{tabular}{|l|c|c|c|c|c|}
\hline \multicolumn{7}{|c|}{ Vegetação Natural } \\
\hline \multirow{2}{*}{ Município } & \multicolumn{2}{|c|}{$\mathbf{2 0 0 0 - 2 0 0 1}$} & \multicolumn{2}{c|}{$\mathbf{2 0 0 4 - 2 0 0 5}$} & Variação \\
\cline { 2 - 7 } & $\mathbf{( h a )}$ & $\mathbf{( \% )}$ & $\mathbf{( h a )}$ & $\mathbf{( \% )}$ & $\mathbf{( \% )}$ \\
\hline Barra do Turvo & $64.904,6$ & 64,1 & $64.848,5$ & 64 & $-0,1$ \\
\hline Cajati & $19.684,0$ & 43,3 & $19.563,5$ & 43 & $-0,3$ \\
\hline Cananéia & $103.161,9$ & 80,3 & $103.099,2$ & 81,1 & 0,8 \\
\hline Eldorado & $128.429,1$ & 75 & $128.396,0$ & 75 & 0 \\
\hline Iguape & $154.132,9$ & 79 & $153.835,7$ & 78,3 & $-0,7$ \\
\hline Ilha Comprida & $11.575,2$ & 63 & $11.563,1$ & 63,5 & 0,5 \\
\hline Itariri & $16.837,0$ & 57 & $16.837,0$ & 57,1 & 0,1 \\
\hline Jacupiranga & $40.832,1$ & 63 & $40.622,1$ & 63,5 & 0,5 \\
\hline Juquiá & $57.641,6$ & 67 & $57.538,8$ & 66,5 & $-0,5$ \\
\hline Miracatu & $73.371,9$ & 79 & $73.140,3$ & 74,6 & $-4,4$ \\
\hline Pariquera-Açu & $19.720,6$ & 53 & $19.612,0$ & 53 & 0 \\
\hline Pedro de Toledo & $60.791,0$ & 91 & $60.798,3$ & 96,4 & 5,4 \\
\hline Registro & $30.948,9$ & 46 & $30.782,7$ & 44,7 & $-1,3$ \\
\hline Sete Barras & $76.529,5$ & 71 & $76.458,1$ & 72 & 1 \\
\hline
\end{tabular}

O Instituto Florestal (IF) do Estado de São Paulo desenvolveu um mapa de uso do solo (escala 1:50.000) com cobertura total de 19 municípios da UGRHI-11, relativo ao ano de 2010. Os municípios que não têm cobertura total deste mapa são: Juquitiba, onde há mapeamento apenas nos extremo sul e oeste do município; São Loureço da Serra, $100 \%$ do município sem mapeamento; Tapiraí, mapeado a porção sul do município e extremo leste; e Ibiúna (novo integrante da UGRHI-11), com 50\% do município mapeado. Este mapa em formato vetorial (shapefile) está disponível para download no site do Sistema de Informações Geográficas da Bacia do Ribeira de Iguape e Litoral Sul (www.sigrb.com.br).

Como citado, este mapeamento não tem cobertura total da Unidade de estudo. Todavia, é possível obter algumas conclusões sobre o Vale do Ribeira.

$\mathrm{Na}$ Tabela 2 podem-se visualizar todas as classes de uso do solo, mapeadas pelo IF, com as respectivas áreas. Separando essas classes de uso do solo em grandes grupos, fica evidente que a maior porção de área da UGRHI-11 está coberta por Vegetação natural $(74,06 \%$ da área total mapeada - 16.206,13 km2), seguido por Agricultura (22,58\%), Corpo de água $(1,61 \%)$, Reflorestamento (1,07\%), Área urbana (0,49\%), Mineração $(0,12 \%)$, Solo exposto $(0,06 \%)$ e Piscicultura $(0,02 \%)$. 
Tabela 2. Classes de uso do solo da UGRHI-11.

\begin{tabular}{|l|r|}
\hline \multicolumn{1}{|c|}{ Classe } & Área (Km2) \\
\hline Agricultura de cultura cíclica & 919,61 \\
\hline Agricultura de cultura permanente & 784,54 \\
\hline Área urbana & 79,35 \\
\hline Areia & 14,24 \\
\hline Campo antrópico & 1955,51 \\
\hline Contato Floresta ombrófila densa/floresta ombrófila mista & 328,93 \\
\hline Corpo de água & 260,16 \\
\hline Floresta ombrófia densa alto montana & 44,38 \\
\hline Floresta ombrófia densa de terras baixas & 920,94 \\
\hline Floresta ombrófia densa montana & 1309,91 \\
\hline Floresta ombrófia densa submontana & 2304,85 \\
\hline Floresta ombrófia mista montana & 0,70 \\
\hline Formação arbórea/arbustiva-herbácea de terrenos marinhos lodosos & 125,06 \\
\hline Formação arbórea/arbustiva-herbácea de várzea & 420,61 \\
\hline Formação pioneira arbustiva-herbácea sobre sedimentos marinhos recentes & 28,39 \\
\hline Mineração & 5,60 \\
\hline Piscicultura & 3,04 \\
\hline Reflorestamento de eucalipto & 121,26 \\
\hline Reflorestamento de pinheiro & 52,00 \\
\hline Solo exposto & 9,31 \\
\hline Vegetação secundária da floresta ombrófia densa de terras baixas & 1267,00 \\
\hline Vegetação secundária da floresta ombrófia densa montana & 1568,86 \\
\hline Vegetação secundária da floresta ombrófia densa submontana & 3082,95 \\
\hline Vegetação secundária da floresta ombrófia densa alto montana & 31,75 \\
\hline Vegetação secundária da floresta ombrófia mista alto montana & 3,94 \\
\hline Vegetação secundária da floresta ombrófia mista montana & 214,00 \\
\hline Vegetação secundária da formação arbórea/arbustiva-herbácea de várzea & 49,27 \\
\hline Vegetação secundária da formação arbórea/arbustiva-herbácea de terrenos & 0,75 \\
\hline marinhos lodosos & 298,66 \\
\hline $\begin{array}{l}\text { Vegetação secundária da formação pioneira arbustiva-herbácea } \\
\text { sobre sedimentos marinhos recentes }\end{array}$ & 0,58 \\
\hline Vegetação secundária do contato floresta ombrófila densa/floresta ombrófila mista & \\
\hline
\end{tabular}

O objetivo deste trabalho foi desenvolver possíveis cenários futuros de uso e ocupação do solo, baseando-se na evolução deste uso durante 24 anos (1986 - 2010) e prever cenários para 2025, analisando o crescimento ou regressão das classes de uso e ocupação do solo. $\mathrm{Na}$ região litorânea, a área possivelmente atingida pelo nível máximo da preamar em 2025 foi sobreposta às classes de uso e ocupação do solo simuladas para o ano 2025. Espera-se que o material resultante desta tese de doutorado possa ser utilizado como uma ferramenta aos 
gestores da UGRHI-11, para projetos municipais de crescimento urbano ou abertura de novas áreas agrícolas.

Durante o período de doutorado o aluno realizou estágio pelo Programa Institucional de Bolsas de Doutorado no Exterior da Coordenação de Aperfeiçoamento de Pessoal de Nível Superior (PSDE/CAPES) no Departamento de Geografia Física e Análises Geográficas Regionais da Universidade de Sevilla (Espanha) entre novembro de 2011 e junho de 2012, sob supervisão do Prof. Dr. José Ojeda Zújar. Durante este Estágio-sanduíche foram desenvolvidos mapas para análise de risco de um possível aumento do nível do mar no litoral sul do Estado de São Paulo, para os anos 2025, 2050 e 2100. Este tema está detalhado no capítulo 11 (Cálculo da vulnerabilidade a um potencial aumento no nível do mar no Complexo Estuarino-Lagunar de Iguape-Cananéia).

\section{LOCALIZAÇÃO}

A UGRHI-11 situa-se no extremo sudeste do Estado de São Paulo, limitando-se a sudoeste com o Estado do Paraná, ao norte com a UGRHI 14 (Alto Paranapanema) e UGRHI 10 (Sorocaba e Médio Tietê), a nordeste com as UGRHI 6 (Alto Tietê) e UGRHI 7 (Baixada Santista), e a leste com o Oceano Atlântico. Sua área é de $17.067,92 \mathrm{~km}^{2}$, sendo a área total da Bacia do rio Ribeira de Iguape, incluindo a porção paranaense, de $25.681 \mathrm{~km}^{2}$ (Figura 4). Os principais rios da Bacia: Ribeira, na sua parte inferior denominado Ribeira de Iguape e seus afluentes Açungui, Capivari, Pardo, Turvo, Juquiá, São Lourenço, Jacupiranga, Una da Aldeia e Itariri. Na região se encontram os reservatórios de Alecrim, Barra, França, Porto Raso, Salto de Iporanga e Serraria (CBH-RB, 2008). As mais populosas, de acordo com o último levantamento censitário (IBGE, 2010) são: Registro (54.268 habitantes), Cajati (28.370 habitantes), Iguape (27.270 habitantes) e Apiaí (25.183 habitantes). 


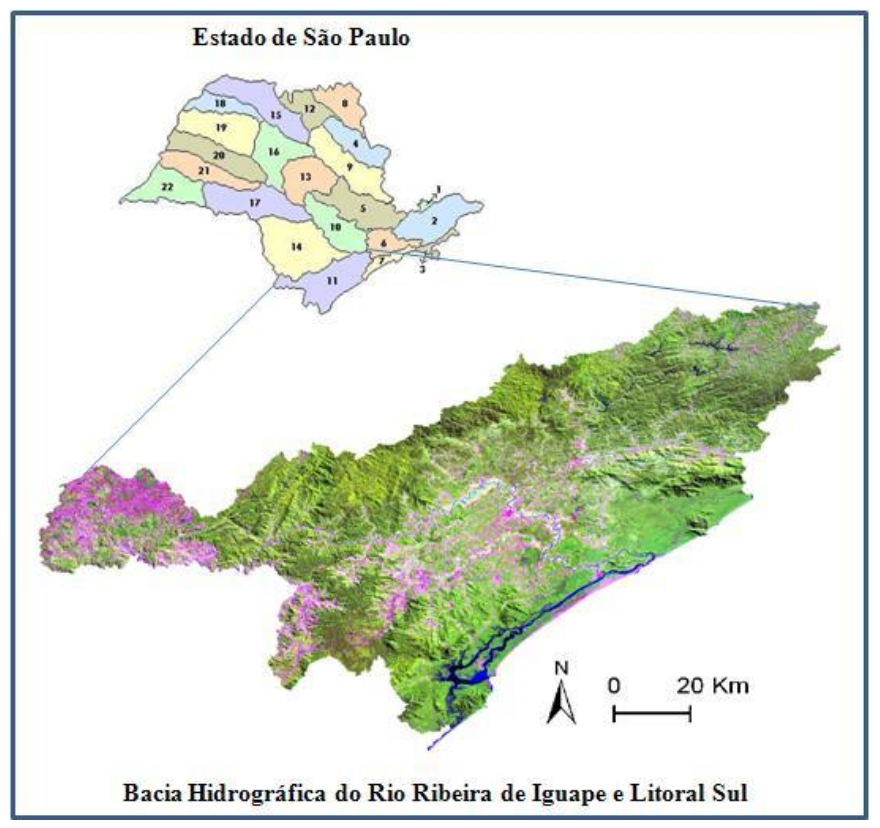

Figura 4. Localização da UGRHI-11 - Bacia Hidrográfica do Ribeira de Iguape e Litoral Sul.

\section{JUSTIFICATIVA}

Considerando-se os dados ambientais e a fragilidade geológica, torna-se importante o estudo do uso e ocupação do solo para compreender a evolução desta área. A região compreende algumas áreas de grande suscetibilidade a escorregamentos e erosão, que devem ser consideradas nos projetos de crescimento urbano e supressão de vegetação para ampliação de áreas agrícolas, em áreas que desprovidas de cobertura podem tornar-se bastante suscetíveis a estes eventos relacionados à estabilidade do terreno.

O Complexo Estuarino-Lagunar de Iguape-Cananéia, no Litoral Sul do Estado de São Paulo, é limitado a leste com o Oceano Atlântico, com $140 \mathrm{~km}$ de extensão e inserido na UGRHI-11 (Figura 5). A região é composta pelos municípios de Cananéia, Iguape e Ilha Comprida, que juntos totalizam uma área de $3.414 \mathrm{Km}^{2}$ e apresentam uma população total de 48.523 habitantes (Cananéia: 12.226; Iguape: 27.270; Ilha Comprida: 9.027). De acordo com alguns métodos matemáticos como o IPCC (Intergovernmental Panel on Climate Change), Ramhstorf, Pfeffer e Titus haverá um aumento no nível do mar que cobrirá significantes áreas do litoral sul paulista. Dessa forma, é importante simular até qual cota altimétrica o nível do mar alcançará e, com os dados produzidos a partir dos cenários futuros de uso do solo, prever quais classes de uso (urbana ou rural e suas subclasses) serão atingidas por esse aumento do nível do mar. 
Importante vantagem da utilização da simulação de cenários está associada ao seu baixo custo. Na maioria das aplicações, o custo de executar um programa computacional é muitas ordens de magnitude menor que o correspondente custo relativo à investigação experimental. Esse fator adquire maior importância à medida que o problema real estudado apresenta maiores dimensões e complexidade (como uma bacia hidrográfica), além dos custos operacionais mais elevados relativos às pesquisas de campo (Pessoa et al, 1997).

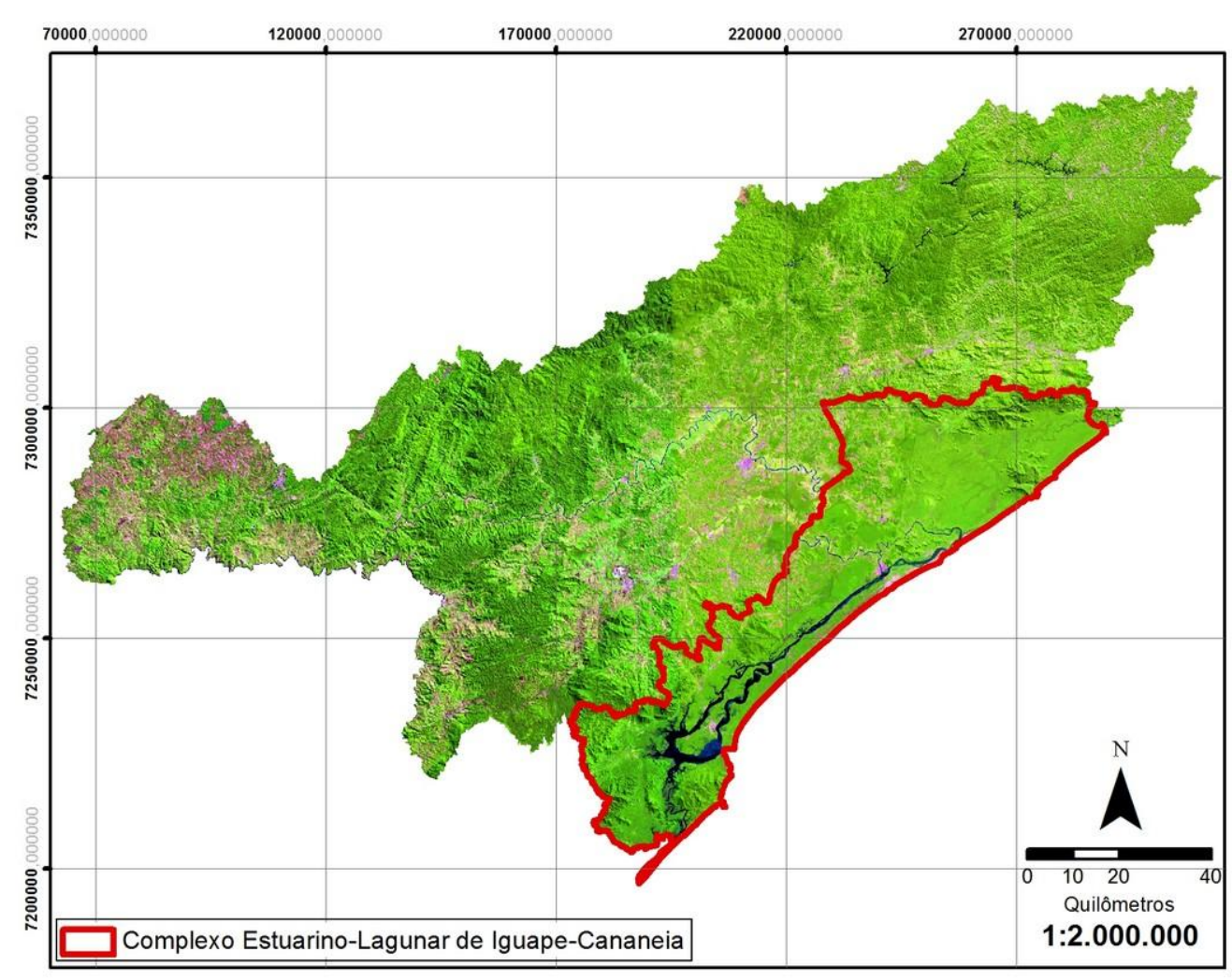

Figura 5. Complexo Estuarino-Lagunar de Iguape-Cananéia. 


\section{DADOS DA ÁREA DE ESTUDO}

Os dados abaixo apresentados são extraídos do Sistema de Informações da Bacia do Ribeira de Iguape e Litoral Sul (SIG-RB), do Relatório de Situação e do Plano Diretor dos Recursos Hídricos da mesma UGRHRI (Macedo et al., 2011).

\subsection{Aptidão agrícola}

Como resultado das condições de relevo, solos e clima, é difícil aplicar às terras da UGRHI-11 as técnicas agrícolas convencionais. Apenas 32,7\% de sua área são adequadas à agricultura, enquanto $13,4 \%$ são adequadas a pastagens, $28,9 \%$ para silvicultura, sendo $25 \%$ totalmente inaptas ao aproveitamento agropecuário (Lepsch et al., 1999).

Segundo MDA (2006), a agricultura comercial do Vale do Ribeira apresenta valor da produção agrícola total em torno de $\mathrm{R} \$ 173$ milhões e baseia-se, preponderantemente, no cultivo do tomate com um valor da produção de $\mathrm{R} \$ 52,7$ milhões, que corresponde a $88 \%$ do total do cultivo das lavouras temporárias, sendo que $93 \%$ do cultivo das lavouras permanentes são formados pela banana ( $\mathrm{R}$ \$ 75,7 milhões), tangerina ( $\mathrm{R}$ \$ 15,9 milhões) e maracujá ( $\mathrm{R}$ \$ 13,6 milhões). Esses são apenas alguns dos números encontrados e que apontam para concentração da exploração agrícola em praticamente uma cultura temporária (tomate) e três permanentes (banana, tangerina e maracujá). Também foi verificado que os produtos comercializados oriundos das lavouras temporárias e permanentes têm sua produção predominantemente destinada aos intermediários.

A seguir serão apresentados os dados referentes às Unidades de Produção Agropecuária do Vale do Ribeira do Iguape e Litoral Sul, extraídos do Levantamento Censitário das Unidades de Produção Agropecuária do Estado de São Paulo (LUPA). Os dados referentes ao ano agrícola 1995/1996 estão contidos na Tabela 3. Já os dados referentes ao ano agrícola 2007/2008 estão contidos na Tabela 4 (SAE/SP, 2008). 
Tabela 3. Estatísticas Agrícolas, 1995/96. Fonte: SAE/SP, 2008.

\begin{tabular}{lrc}
\hline \multicolumn{1}{c}{ Estatísticas Agrícolas, 1995/96 } & Área (hectare) & $\mathbf{( \% )}$ \\
\hline Área com cultura perene & $50.215,10$ & 5,91 \\
Área com cultura semi-perene & $21.848,40$ & 2,57 \\
Área com cultura anual & $15.823,20$ & 1,86 \\
Área com pastagem & $233.136,80$ & 27,44 \\
Área de reflorestamento & $16.740,40$ & 1,97 \\
Área de vegetação natural & $450.569,30$ & 53,03 \\
Área inaproveitada & $30.413,20$ & 3,58 \\
Área inaproveitável & $10.894,20$ & 1,28 \\
Área complementar & $19.948,90$ & 2,35 \\
Área total & $849.589,50$ & 100,00 \\
\hline
\end{tabular}

No ano agrícola 1995/1996 as classes com maior representatividade na área da UGRHI-11 eram as áreas de pastagem e de vegetação natural, com 27,44\% e 53,03\% da área total da bacia, respectivamente.

Atentar ao detalhe de ambas as tabelas não possuirem o mesmo número de linhas, consequentemente, os mesmos itens. Este fato é devido à forma que estes dados estão apresentados no site do Levantamento Censitário das Unidades de Produção Agropecuária do Estado de São Paulo (LUPA). Provavelmente os dados coletados em campo, através do preenchimento de um questionário para cada unidade de levantamento, UPA (conjunto de propriedades agrícolas contíguas e pertencentes ao(s) mesmo(s) proprietário(s), com área total igual ou superior a 0,1ha), foram tabulados de diferentes maneiras nos Censos de 1995/96 e 2007/08.

Tabela 4. Estatísticas Agrícolas, 2007/08. Fonte: SAE/SP, 2008.

\begin{tabular}{lrc}
\hline \multicolumn{1}{c}{ Estatísticas Agrícolas, 2007/08 } & Área (hectare) & $\mathbf{( \% )}$ \\
\hline Área com cultura perene & $42.678,30$ & 4,72 \\
Área com cultura temporária & $23.756,10$ & 2,63 \\
Área com pastagens & $225.346,80$ & 24,93 \\
Área com reflorestamento & $37.130,70$ & 4,11 \\
Área com vegetação natural & $514.427,80$ & 56,91 \\
Área com vegetação de brejo e várzea & $7.755,70$ & 0,86 \\
Área em descanso & $36.428,30$ & 4,03 \\
Área complementar & $16.461,80$ & 1,82 \\
Área total & $903.985,50$ & 100,00 \\
\hline
\end{tabular}


Semelhante ao apresentado na Tabela 3, os dados referentes ao ano agrícola 2007/08 demonstram que as áreas com pastagens e de vegetação natural continuam sendo as mais representativas, com $24,93 \%$ e 56,91\%, respectivamente. A área total referente ao conjunto das UPAs apresenta aumento de 54,396 hectares. Isso explica o fato das áreas de pastagens apresentarem menor representação total (percentagem) em 2007/08 em relação à 1995/06, porém sua área aumentou em 7.790 hectares, neste período. As áreas de reflorestamento apresentaram grande aumento durante o período: 16.740,4 hectares em 1995,96, e 37.130,7 hectares em 2007/08, com crescimento de 121,8\%.

\subsection{Economia: atividades e potencialidades}

A renda da população da região é baixa: um indicador é que, para uma população de 361.224 habitantes (IBGE, 2010), 26.305 famílias estavam cadastradas para receber Bolsa Família em dezembro de 2010, o que equivale, considerando quatro pessoas por família, a $29,13 \%$ da população, chegando a superar $40 \%$ em quatro municípios (Caixa Econômica Federal, 2011).

\section{DADOS FÍSICOS E AMBIENTAIS}

\subsection{Processos geológicos: dinâmica superficial}

Os processos de dinâmica superficial são aqueles que modificam a superfície da Terra, produzindo diferentes paisagens conforme a estruturação geológica, climática e o tempo de atuação (Silva, 2002).

Os principais processos de dinâmica superficial que modificam a paisagem estão relacionados à gravidade, às marés, à radiação solar e ao calor interno. Diversos agentes podem estar envolvidos na geração do processo (água, vento, gelo e organismos), que são agrupados genericamente como erosão, processo de desagregação e remoção das partículas do solo ou de fragmentos e partículas de rocha, que pode ter causas naturais ou antrópicas (Infante Jr. e Fornasari Filho, 1998).

A erosão constitui um processo natural no desenvolvimento da paisagem, pois modifica, normalmente após longos períodos de tempo, a forma de relevo. Com interferência 
do homem esse processo pode ser acelerado devido a desmatamentos, agricultura e obras urbanas ou viárias. As conseqüências dessa erosão acelerada ou antrópica são redução do potencial de áreas agriculturáveis, danos a equipamentos de infra-estrutura nas áreas urbanas e o assoreamento dos rios, lagos, represas e reservatórios (Silva, 2002).

Segundo da Silva (2002), há dois tipos de erosão, que dependem do tipo de escoamento:

- erosão laminar ou erosão em lençol: causada pelo escoamento difuso das águas das chuvas, resultando na remoção progressiva e uniforme dos horizontes superficiais do solo;

- erosão linear: causada pela concentração das linhas de fluxo das águas de escoamento difuso das águas de escoamento superficial, resultando pequenas incisões na superfície do terreno, em forma de sulcos, que pode evoluir, por aprofundamento, para ravinas.

Outro tipo de processo de dinâmica superficial é o do movimento de massa gravitacionais, que são induzidos pela ação gravitacional. São em parte responsáveis pela evolução das formas do relevo e causam grandes danos socioeconômicos quando em desequilíbrio (Guidicini e Nieble, 1984). Tais movimentos envolvem o deslocamento de rocha e/ou solo vertente abaixo (Costa E Baker, 1984). Segundo Augusto Filho (1994), os movimentos de massa gravitacionais podem ser agrupados em quatro grandes classes: rastejos, escorregamentos, quedas e corridas.

São processos relacionados com aspectos naturais, como chuvas intensas e prolongadas, estruturas geológicas, declividades acentuadas, drenagem superficial e subsuperficial, e vegetação. Porém, cabe salientar que há relação entre os movimentos de massa e as áreas onde existe interferência na natureza para a construção de estradas e habitações.

Segundo Augusto Filho (1992), as principais modificações antrópicas que induzem os movimentos de massa são: remoção de cobertura vegetal; lançamento e concentração de águas pluviais; vazamentos na rede de abastecimento, esgoto e presença de fossas; execução de cortes com geometria inadequada; execução deficiente de aterros; lançamento de lixo em encostas; e vibrações produzidas por tráfego pesado, explosões. 


\subsection{Geologia}

A interpretação da geologia da área compreendida pela bacia do Ribeira de Iguape e Litoral Sul é sujeita a controvérsias acirradas entre os geólogos e outros profissionais que a estudaram, o que obriga a tomar partido e declará-lo. O resumo que se segue foi elaborado pelo Prof. Dr. Ginaldo Ademar da Cruz Campanha, do Instituto de Geociências da USP, sendo as interpretações baseadas em seus trabalhos de campo e laboratório, e apresentadas em Campanha et. al. (1995). O mapa geológico encontra-se na Figura 6.

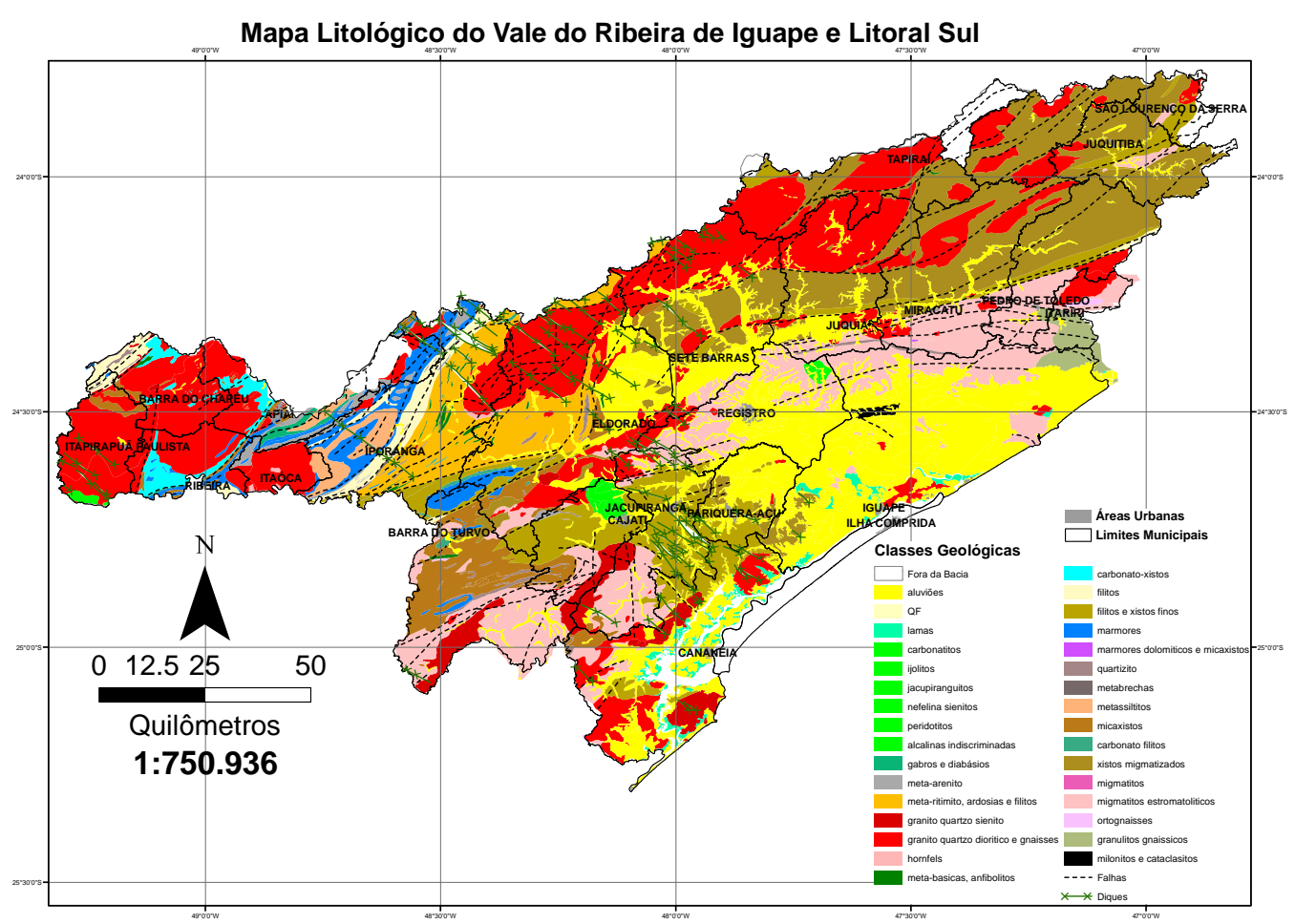

Figura 6. Mapa litológico do Vale do Ribeira do Iguape e Litoral Sul.

A bacia do Ribeira pode ser subdividida em dois grandes domínios geológicos: as baixadas litorâneas, constituídas predominantemente por depósitos sedimentares cenozóicos, e as serranias costeiras, constituídas em geral por rochas do embasamento cristalino, com idades pré-cambrianas a eopaleozóicas, mas também com algumas importantes manifestações ígneas mesozóicas.

A evolução geológica pode ser sintetizada em três grandes estágios. Um orogênico, com idades entre 650 e $540 \mathrm{Ma}$ (mas envolvendo também terrenos mais antigos), associado a deformação, metamorfismo e magmatismo, constituindo o que se costuma denominar cinturão 
Ribeira. No segundo, ao final desse período e com o resfriamento do cinturão Ribeira, a região passa a fazer parte de um supercontinente, o Gondwana, com um longo período de estabilidade tectônica que durou até o Mesozóico. Do período Gondwânico os únicos registros geológicos na área da bacia do Ribeira ocorrem no seu extremo oeste, no Estado do Paraná, com a deposição das formações Furnas e Ponta Grossa, da base da bacia sedimentar do Paraná, durante o Paleozóico (Devoniano). O terceiro estágio relaciona-se com a ruptura do Gondwana, e a consequente separação entre América do Sul e África, durante o Mesozóico, entre o Jurássico e o Cretáceo, sendo representada por importante enxame de diques de rochas básicas com orientação NW, denominado de alinhamento de Guapiara, além de grandes corpos aproximadamente circulares de rochas ígneas alcalinas, como os de Jacupiranga, Juquiá e Pariqüera-Açu. A evolução tectônica, sedimentar e geomorfológica que se segue durante o Cenozóico, é balizada pela separação dos continentes e a evolução da margem continental brasileira.

A estruturação geológica é, em grande parte, dada pelos terrenos cristalinos mais antigos. Nestes um sistema de zonas de cisalhamento transcorrentes, com direção ENE, desenvolvido entre o final do Pré-cambriano e o início do Paleozóico, condiciona os principais compartimentos geológicos. Até mesmo as unidades ígneas mesozóicas e sedimentares cenozóicas mostram algum condicionamento por essas estruturas mais antigas, através da reativação das estruturas antigas nos períodos mais modernos. A mais proeminente dessas estruturas é a zona de cisalhamento ou falha de Cubatão.

\subsection{Geomorfologia}

A análise geomorfológica mais recente da Bacia do Ribeira de Iguape, abrangendo terras dos Estados de São Paulo e Paraná, foi desenvolvida por Ross (2002) tendo como suporte o mapeamento geomorfológico a partir de imagens de radar e satélite na escala 1:250.000, bem como a utilização de cartas topográficas, geológicas e pedológicas, com a preocupação de promover-se a análise integrada dos componentes naturais, objetivando fornecer subsídios para definição de unidades dos sistemas ambientais e sua respectiva cartografação, visando apoiar a gestão territorial. O mapa geomorfológico da UGRHI-11 está na Figura 7.

Ross (2002) identificou na bacia do Ribeira de Iguape, a partir da análise efetuada na escala de 1:250.000, sete unidades ou macrocompartimentos de relevo, sendo quatro em terras 
altas e três em terras baixas. Essas unidades foram organizadas sob duas grandes morfoestruturas: uma denominada de Morfoestrutura da Faixa de Dobramentos do Atlântico, onde se podem identificar três Unidades Morfoesculturais denominados de Planalto e Serra de Paranapiacaba, Serra do Mar e Morros Litorâneos, Planalto de Guapiara e Planalto do Alto Ribeira-Turvo. A outra unidade morfoestrutural, que envolve as terras baixas denominou-se de Unidade Morfoestrutural da Depressão Tectônica do Baixo Ribeira, onde se pode identificar três Unidades Morfoesculturais, quais sejam: Depressão Tectônica do Baixo Ribeira, Planície Costeira Cananéia-Iguape e Planícies e Terraços Fluviais do Baixo Ribeira.

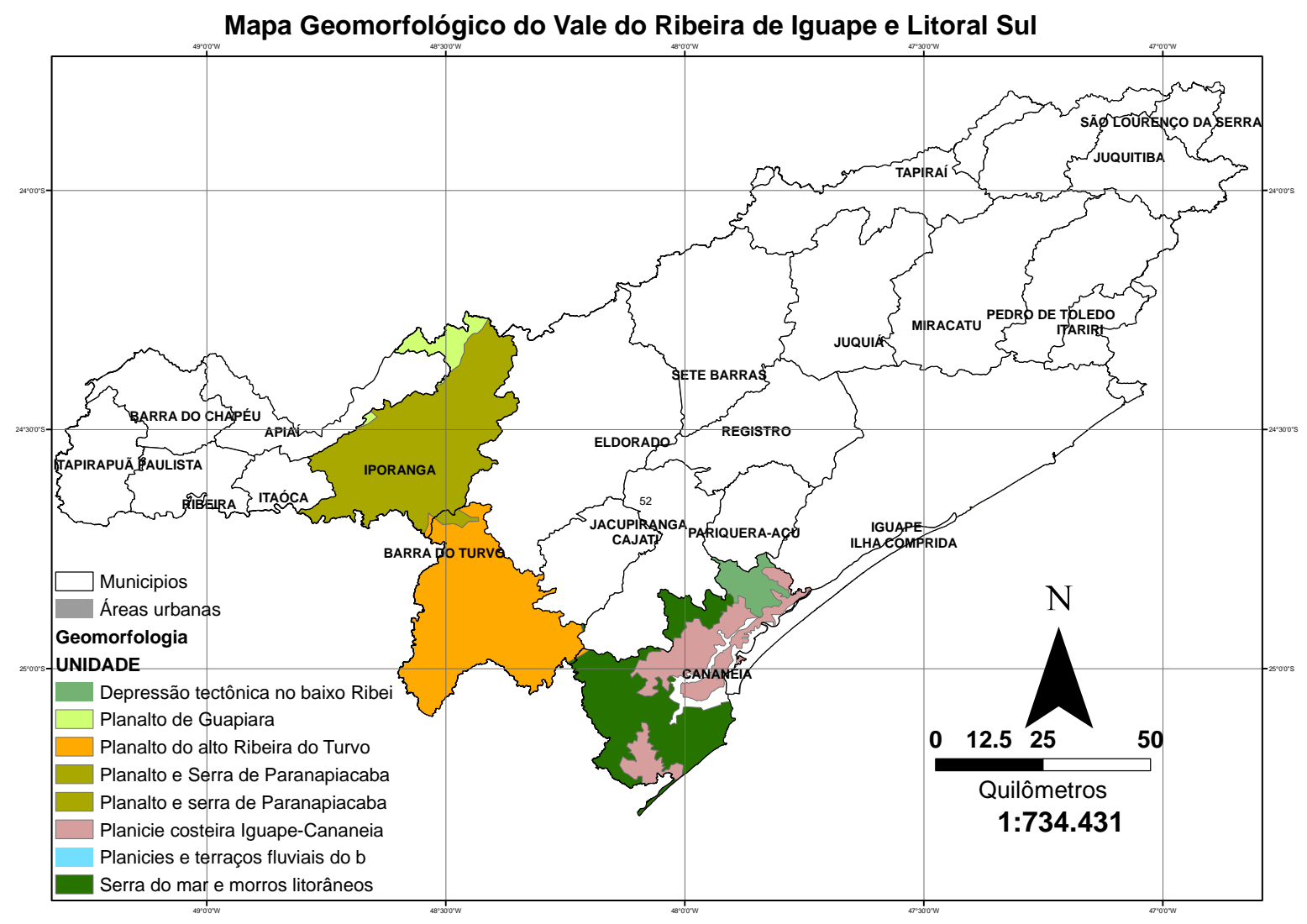

Figura 7. Mapa geomorfológico do Vale do Ribeira do Iguape e Litoral Sul.

\subsection{Pedologia}

De acordo com o Sistema Brasileiro de Classificação de Solos (EMBRAPA, 1999), solo é definido como uma coleção de corpos naturais, constituídos por partes sólidas, líquidas e gasosas, tridimensionais, dinâmicos, formados por materiais minerais e orgânicos, que ocupam a maior parte do manto superficial das extensões continentais da Terra, contém 
matéria viva e podem ser vegetados, onde ocorrem. Ocasionalmente podem ter sido modificados por atividades humanas.

As classes de solos diferenciam-se em relação à cor, espessura, textura e constituição química e mineralógica. Porém, todas são resultantes de um conjunto de ações a que esteve submetido determinado material de origem. Estas ações são diretamente relacionadas aos fatores de formação (Oliveira, 2005).

São cinco os fatores de formação do solo: material de origem, clima, relevo, organismos e tempo, que atuam concomitantemente (Jenny, 1941 apud Oliveira, 2005).

A carta pedológica da UGRHI-11 foi baseada em Lepsch et al. (1999), que utiliza a mesma legenda de solos do Mapa de 1960. Porém, quando existentes, são citadas as atualizações do atual Sistema Brasileiro de Classificação de Solos (SBCS). Esta carta, na escala 1:250.000, é do tipo semi-detalhado, ou seja, a sua precisão é variável. Para as áreas de melhor acesso é, em geral, mais preciso, enquanto que, para os terrenos inacessíveis, corresponde a um reconhecimento de média e alta precisão. Os solos identificados refletem, de um modo geral, as particularidades climáticas, o relevo plano de várzea ou acidentado em rochas cristalinas. O mapa pedológico da UGRHI-11 está na Figura 8.

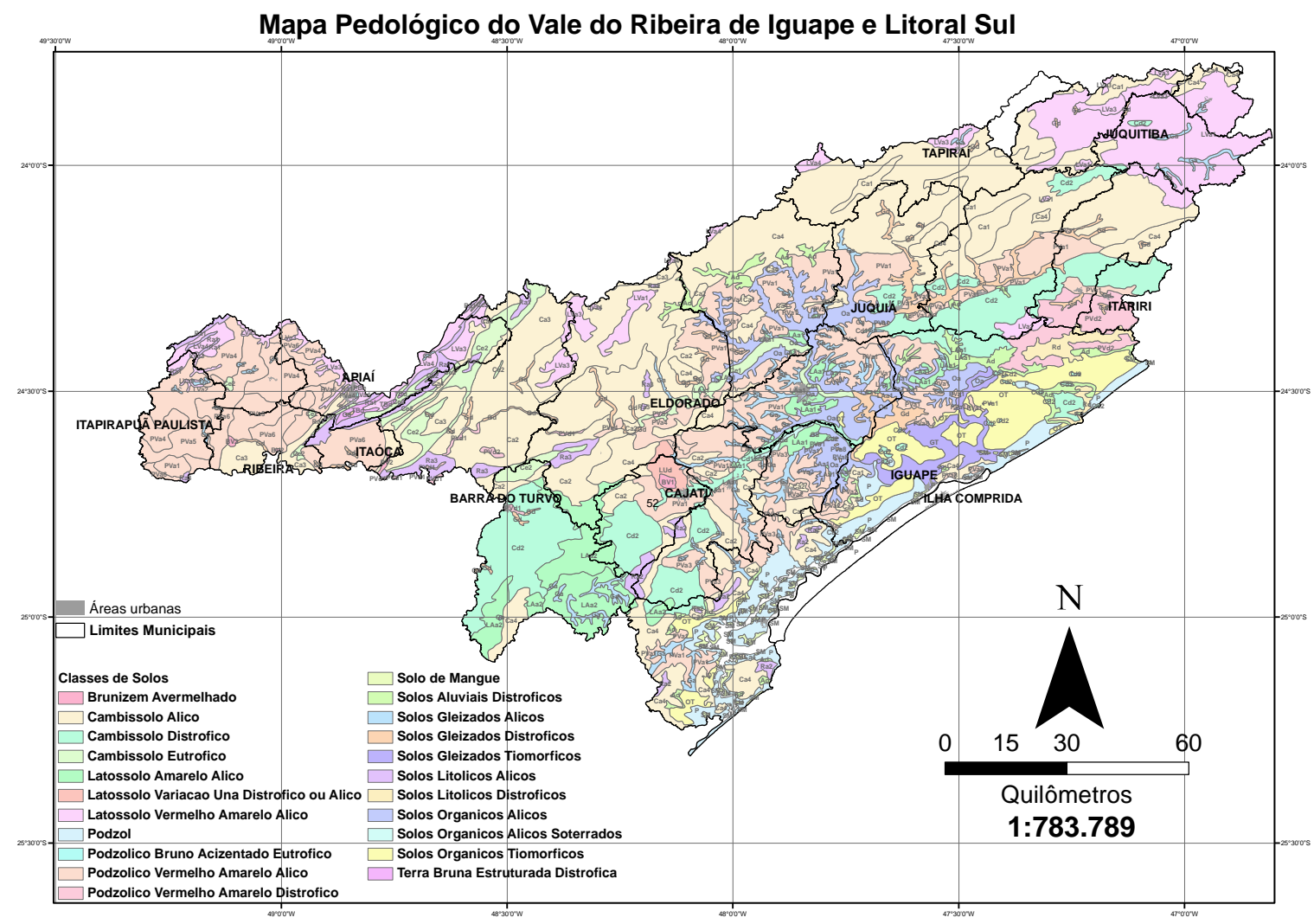

Figura 8. Mapa pedológico do Vale do Ribeira do Iguape e Litoral Sul. 


\section{A - Latossolos}

Solos constituídos por material mineral, apresentando horizonte B latossólico, imediatamente abaixo de qualquer tipo de horizonte A, dentro de $200 \mathrm{~cm}$ da superfície do solo ou dentro de $300 \mathrm{~cm}$, se o horizonte A apresentar mais de $150 \mathrm{~cm}$ de espessura (OLIVEIRA, 1999).

Nos Latossolos de textura média, o teor relativamente elevado de areias confere-lhes uma geometria de poros onde os macroporos são preponderantes. Nesta situação, e devido à ausência de impedimentos internos (coesão elevada), a permeabilidade da água através do solo é rápida. Em alguns casos a elevada quantidade de areia determina também uma retenção de água relativamente baixa, o que qualifica os solos desta classe como pouco filtrantes. Devido à sua elevada permeabilidade interna e à baixa capacidade adsortiva, esses solos se qualificam como pouco filtrantes.

Segundo Lombardi Neto e Bertoni (1975) apud Oliveira (1999), os Latossolos apresentam boa tolerância à perda por erosão. Já os Latossolos de textura franco arenosa, devido às baixas taxas de coesão e adesão, são mais suscetíveis à erosão. Tal fato, contudo, é amenizado pelo relevo geralmente aplainado ou suave ondulado onde se encontram tais solos.

Os Latossolos da UGRHI-11 são dos tipos: Latossolo Amarelo Álico; Latossolo Vermelho-Amarelo Álico; Latossolo Variação Una Distrófico ou Álico, no atual Sistema Brasileiro de Classificação de Solos (SBCS), esta classe é correspondente ao Latossolo Amarelo.

\section{B - Terra Bruna Estruturada Distrófica}

Foi englobado no SBCS (EMBRAPA, 1999) como Latossolos Brunos. Em certos casos, são subordinados ao Argissolo Vermelho-Amarelo. São solos com Horizonte A com mais de $30 \mathrm{~cm}$ de espessura, com teores de carbono orgânico acima de $1 \%$, inclusive no BA; textura argilosa ou muito argilosa em todo horizonte B; e alta capacidade de retração do solo, com perda de umidade evidenciada pelo fendilhamento acentuado em cortes de barrancos expostos ao sol por curto espaço de tempo (aproximadamente uma semana), formando uma estrutura do tipo prismática. 


\section{C - $\underline{\text { Podzólicos }}$}

Reclassificado no Sistema Brasileiro de Classificação dos Solos (EMBRAPA, 1999) como Argissolo. Os Argissolos compreendem, depois dos Latossolos, a ordem mais extensa de solos brasileiros. Eles abrangem uma gama enorme de solos, desde eutróficos, distróficos a álicos até alumínicos, rasos a muitos profundos, abruptos ou não, com cascalho, cascalhentos ou não, com fragipã e até com caráter solódico, o que torna difícil uma apreciação generalizada para os solos dessa ordem como um todo (OLIVEIRA, 2005).

Os Argissolos são geralmente solos muito profundos, não apresentam impedimentos físicos à penetração do sistema radicular pelo menos até $200 \mathrm{~cm}$ de profundidade. A presença de saprolitos a menos de $200 \mathrm{~cm}$ de profundidade não impede o enraizamento, pois tais camadas são espessas e a rocha intemperizada é branda. Estas camadas podem constituir-se em importantes zonas de reservas de nutrientes (OLIVEIRA, 1999). Oliveira (2005) divide os Argissolos em duas subordens: Argissolos VermelhoAmarelo e Argissolos Vermelhos.

Em relação à estabilidade, Lombardi et. al (1991) apud OLIVEIRA (1999) classifica os Argissolos com baixa ou muito baixa resistência a erosão.

\section{D - Podzólico Bruno-Acizentado Eutrófico}

Reclassificado no SBCS (EMBRAPA, 1999) como Luvissolo Hipocrômico. Os Luvissolos, em sua grande maioria, apresentam textura arenosa ou média em superfície, fato que determina consistência macia, friável, ligeiramente plástica e pegajosa, apesar de a fração argila ser de elevada atividade. São solos férteis e com bom potencial nutricional (OLIVEIRA, 2005).

Suas limitações são devidas principalmente à baixa permeabilidade do horizonte B, principalmente nos Luvissolos planossólicos. Esta propriedade facilita os processos erosivos sendo por isso solos com acentuada erodibilidade. Tal característica é maximizada nos solos situados em relevo ondulado nos quais a declividade pode chegar a 10-15\% (OLIVEIRA, 1999). 


\section{E - $\underline{\text { Podzol }}$}

Reclassificado no SBCS (EMBRAPA, 1999) como Espodossolos. No Brasil, os Espodossolos, em sua grande maioria, possuem textura arenosa ao longo do perfil, sendo pouco freqüentes os que apresentam horizonte $\mathrm{B}$ de textura média e raros os de textura argilosa. A condição de textura arenosa determina elevada permeabilidade, ressecamento rápido, elevada taxa de decomposição da matéria orgânica e virtual ausência de reservas em nutrientes, posto que a fração grosseira seja constituída, com raras exceções, por quartzo (OLIVEIRA, 2005).

São solos essencialmente arenosos, assemelhando-se bastante, quanto ao comportamento físico e químico, aos Neossolos Quartzarênicos. Devido à baixa adesão e coesão apresentam elevada erodibilidade (OLIVEIRA, 1999).

\section{F - Brunizém Avermelhado}

Reclassificado no SBCS (EMBRAPA, 1999) como Chernossolos. Solos muito férteis, pois apresentam elevada CTC e saturação por bases elevada, o que determina uma alta capacidade de suprimento de macronutrientes para as plantas. A maioria desses solos está situada em relevo escarpado associado à presença de rochas expostas e geograficamente associados a solos rasos (OLIVEIRA, 1999).

Apesar de todos os Chernossolos identificados serem argilúvicos, o conhecimento que se tem desses solos, no Estado de São Paulo, é que sua relação textural é pouco acentuada, o que lhes confere menor erodibilidade que os Argissolos Vermelho-Amarelo, mantida a igualdade de declive e cobertura vegetal (OLIVEIRA, 1999).

\section{$\mathrm{G}-\underline{\text { Cambissolos }}$}

O conceito central é o de solos em estágio intermediário de intemperismo, isto é, que não sofreram alterações físicas e químicas muito avançadas. É também uma característica desses solos a pequena variação do teor de argila ao longo do perfil, exceção feita aos Cambissolos desenvolvidos de sedimentos aluviais, os quais podem apresentar distribuição de argila bastante irregular (OLIVEIRA, 2005). 
A maior parte dos Cambissolos do Estado de São Paulo ocorre em duas situações bem distintas, a mais extensa é aquela representada por terrenos situados em relevo bastante acidentado variando de forte ondulado a escarpado, enquanto a outra é representada por terrenos planos de planícies aluviais. Tais solos apresentam elevada erodibilidade e forte a muito forte limitação á trafegabilidade a qual é ainda penalizada pelos freqüentes afloramentos de rochas e pela presença de solos rasos representados pelos Neossolos Litólicos (OLIVEIRA, 1999).

\section{$\mathrm{H}$ - $\underline{\text { Solos Gleizados }}$}

Reclassificado no SBCS (EMBRAPA, 1999) como Gleissolos. A ordem dos Gleissolos compreende solos hidromórficos constituídos por material mineral. A grande maioria desses solos encontra-se em planícies aluviais, em locais onde o nível freático, normalmente, é elevado (menos de $50 \mathrm{~cm}$ da superfície do terreno). A condição de drenagem interna má a muito má é, portanto, geral para todos os solos dessa classe. Essas características constituem sérias limitações ao uso agrícola e não-agrícola (OLIVEIRA, 2005). Os Gleissolos apresentam alto potencial erosivo devido à alta erosividade.

\section{I- $\underline{\text { Solos Orgânicos }}$}

Reclassificados no SBCS (EMBRAPA, 1999) como Organossolos. Compreendem solos pouco evoluídos, constituídos por material orgânico proveniente de acumulações de restos vegetais em grau variável de decomposição, acumulados em ambientes mal a muito mal drenados, ou em ambientes úmidos de altitude elevada. Em todos os casos, possuem coloração preta, cinzenta muito escura ou marrom e elevados teores de carbono orgânico (OLIVEIRA, 2005).

Os Organossolos do Estado de São Paulo são todos formados em planícies aluviais, com ambiente palustre. Em vista da elevada quantidades de matéria orgânica, em estágios variados de decomposição, apresentam densidade aparente muito baixa, elevada porosidade e capacidade de retenção de água, baixa capacidade de suporte (alta compressibilidade) e elevado poder tampão (OLIVEIRA, 1999). 


\section{$\mathrm{J}$ - $\underline{\text { Solos Aluviais }}$}

Reclassificados no SBCS (EMBRAPA, 1999) como Neossolos Flúvicos. Os Neossolos Flúvicos apresentam profundidades variadas. Em média, porém, predominam os solos profundos, sendo o fator limitante a presença de lençol freático, o qual está sempre bem mais profundo que nos Gleissolos, com os quais estes solos se associam na paisagem. Podem apresentar textura argilosa, média ou arenosa (OLIVEIRA, 1999). Formados em sedimentos aluviais e situados em relevo aplainado ou deprimido, portanto, sem problemas relacionados à erosão (OLIVEIRA, 2005).

\section{K - $\underline{\text { Solos Litólicos }}$}

Reclassificados no SBCS (EMBRAPA, 1999) como Neossolos Litólicos. Solos com horizonte A ou $\mathrm{O}$ com menos de $40 \mathrm{~cm}$ de espessura assente diretamente sobre rocha ou sobre horizonte $\mathrm{C}$ ou $\mathrm{Cr}$ ou sobre material com $90 \%$ (por volume) ou mais de sua massa constituída por fragmentos de rocha com diâmetro maior que $2 \mathrm{~mm}$ (cascalhos, calhaus e matacões) e que apresentam caráter litóide dentro de $50 \mathrm{~cm}$ da superfície do solo. Como a maioria dos Neossolos Litólicos ocorrem em relevo forte ondulado ou montanhoso são muito suscetíveis à erosão e apresentam sérias limitações à trafegabilidade (OLIVEIRA, 1999).

\section{L - $\underline{\text { Solos de Mangue }}$}

Tais solos correspondem aos Gleissolos Tiomórficos e Gleissolos Sálicos do SBCS (EMBRAPA, 1999). Não são usados na agricultura. Encontram-se, praticamente cobertos pela vegetação natural de mangue, sujeitos às marés. A presença de material sulfídrico é comum nesses solos, desenvolvendo elevada acidez ( $\mathrm{pH}$ em água inferior a 3,5) (OLIVEIRA, 1999). 


\subsection{Cobertura vegetal}

De acordo com levantamento da vegetação natural remanescente do Estado de São Paulo, publicado em 2007, a Região Administrativa de Registro apresentou redução na área de vegetação de 1.465,1 hectares (0,17\%) no período de 2000-2001 a 2004-2005 (Tabela 5). O maior aumento ocorreu com a Vegetação Secundária da Floresta Ombrófila Densa Montana, e a maior redução ocorreu com a Vegetação Secundária da Floresta Ombrófila Densa Submontana (Instituto Florestal, 2007).

Tabela 5. Diferentes categorias de vegetação mapeadas e quantificadas nos períodos de 2000-2001 e 2004-2005, na Região Administrativa de Registro.

\begin{tabular}{|c|c|c|c|c|}
\hline Legenda & 2000-2001 & Aumento & Redução & 2004-2005 \\
\hline Floresta Ombrófila Densa Montana & $96.721,70$ & & 269,00 & $96.452,70$ \\
\hline Floresta Ombrófila Densa Submontana & $164.988,90$ & & 243,50 & $164.745,40$ \\
\hline Floresta Ombrófila Densa das Terras Baixas & $50.267,30$ & & 70,10 & $50.197,20$ \\
\hline $\begin{array}{l}\text { Floresta Ombrófila em Contato Floresta Ombrófila/ } \\
\text { Floresta Ombrófila Mista Montana }\end{array}$ & $192.228,90$ & & 95,20 & $192.133,70$ \\
\hline Floresta Ombrófila Mista Montana & 91,70 & & & 91,70 \\
\hline Formação Arbórea/Arbustiva-herbácea de Terrenos Marinhos Lodosos & $11.767,90$ & & & $11.767,90$ \\
\hline Formação Arbórea/Arbustiva-herbácea em Região de Várzea & $32.090,40$ & & 174,40 & $31.916,00$ \\
\hline Formação Arbórea/Arbustiva-herbácea sobre Sedimentos Marinhos Recentes & $98.321,20$ & & 54,30 & $98.266,90$ \\
\hline Vegetação Secundária da Floresta Ombrófila Densa Montana & $29.947,20$ & 178,80 & & $30.126,00$ \\
\hline Vegetação Secundária da Floresta Ombrófila Densa Submontana & $120.484,90$ & & 408,20 & $120.076,70$ \\
\hline Vegetação Secundária da Floresta Ombrófila Densa das Terras Baixas & $55.102,20$ & & 329,50 & $54.772,70$ \\
\hline $\begin{array}{l}\text { Vegetação Secundária da Floresta Ombrófila em Contato Floresta Ombrófila/ } \\
\text { Floresta Ombrófila Mista Montana }\end{array}$ & $6.427,40$ & 6,20 & & $6.433,60$ \\
\hline Vegetação Secundária da Floresta Ombrófila Mista Montana & 120,50 & & 5,90 & 114,60 \\
\hline TOTAL & $858.560,20$ & 185,00 & $1.650,10$ & $857.095,10$ \\
\hline
\end{tabular}

\subsubsection{Descrição da vegetação encontrada na Região Administrativa de Registro}

A Região Administrativa de Registro é composta pelos seguintes municípios: Barra do Turvo, Cajati, Cananéia, Eldorado, Iguape, Ilha Comprida, Jacupiranga, Juquitiba, Miracatu, Pariquera-Açu, Pedro de Toledo, Registro e Sete Barras. A população total da região é de 260.687 habitantes (IBGE, 2010).

A seguir serão descritas as classes de vegetação encontradas na Região Administrativa de Registro, segundo o Inventário Florestal da Vegetação Natural do Estado de São Paulo (Instituto Florestal, 2007): 


\subsubsection{Floresta Ombrófila Densa Montana}

Esta formação é correspondente no sul do País às que se situam de 500 a 1.500 metros, onde a estrutura é mantida até próximo ao cume dos relevos dissecados, quando solos delgados ou litólicos influenciam no tamanho dos fanerófitos, que se apresentam menores. No sul do Brasil a Coniferales Podocarpus, único gênero tropical que apresenta dispersão até a Zona Equatorial, é típica dessa formação, ocorrendo por vezes juntamente com os gêneros da família Lauraceae (Ocotea e Nectandra) e outras espécies de ocorrência Pantropical (Manual técnico da vegetação brasileira, 1991).

Em ambientes bem conservados, ocorrem nos extratos superiores Ocotea catharinensis, O. odorifera, Copaifera trapezifolia, Aspidosperma olivaceum e Cabralea canjerana Nos estratos inferiores destacam-se Inga sessilis, I. marginata, Ilex paraguaiensis e Dycksonia selowiana (RODERJAN \& BRITEZ 2002).

\subsubsection{Floresta Ombrófila Densa Submontana}

O dissecamento do relevo montanhoso e dos planaltos com solos medianamente profundos é ocupado por uma formação florestal que apresenta os fanerófitos com alturas aproximadamente uniformes. A submata é integrada por plânulas de regeneração natural, poucos nanofanerófitos e caméfitos, além da presença de palmeiras de pequeno porte e lianas herbáceas em maior quantidade (Manual técnico da vegetação brasileira, 1991).

As florestas ombrófilas densas submontanas se estendem pelas encostas das serras entre as altitudes de 50 a 500 metros, podendo ocorrer em vales e grotões protegidos nas cotas superiores. Trata-se da formação florestal característica das representações da Mata Atlântica. Seu estágio climáxico é composto por árvores de alturas aproximadamente uniformes, raramente ultrapassando 30 metros. Nos vales menos declivosos, onde existe um espesso manto de detritos vegetais, no entanto, as maiores árvores podem atingir mais de 40 metros de altura. Devido à declividade do terreno no qual se desenvolve, essa floresta apresenta estratificação vertical pouco aparente. Ainda devido à declividade e instabilidade das encostas, que produzem deslizamentos constantes, mostra-se como um mosaico de diferentes estágios sucessionais, com grande número de clareiras em regeneração. 
O dossel é mais diverso que aquele da formação, composto por espécies variadas, em sua maioria seletivas higrófilas (PRBMA, 2013). Entre as mais comuns cita-se o Pau-sangue (Pterocarpus violaceus), Guatambu (Aspidosperma olivaceum), Laranjeira-do-mato (Sloanea guianensis), Figueiras (Ficus sp.), Tapiá-guaçu (Alchornea triplinervis), Jequitibá (Cariniana strelensis), Canelas (Ocotea spp, Nectandra spp), Araribá (Centrolobium robustum), Bicuíba (Virola oleifera), Cedros (Cedrella spp), Canjerana (Cabralea canjerana), Maçaranduba (Manilkara subericea), Jatobá (Hymenaea courbaril), Caovi (Pseudopiptadenia warmingii), Baguaçu (Talauma ovata). Nos trechos sucessionais são comuns as Embaúbas (Cecropia spp), Guapuruvu (Schyzollobium parahyba), Manacá-da-serra (Tibouchina mutabilis) e Paude-tucano (Vouchysia tucanorum).

\subsubsection{Floresta Ombrófila Densa das Terras Baixas}

É uma formação que ocupa, em geral, as planícies costeiras, capeadas por tabuleiros pliopleistocênicos do Grupo Barreiras. Ocorre desde a Amazônia, estendendo-se através de todo o Nordeste, até as proximidades do rio São João, no Estado do Rio de Janeiro. Nesta formação dominam duas "ochlospécies", sendo Calophyllum brasiliense a partir do Estado de São Paulo para o sul até a costa Centro-sul de Santa Catarina e Ficus organensis, terminado sua ocorrência às margens da Lagoa dos Patos, no Rio Grande do Sul (Manual técnico da vegetação brasileira, 1991).

Por estarem localizadas em áreas planas litorâneas, essas formações florestais foram fragmentadas, convertidas e ocupadas desde o início da colonização. Ainda hoje, os poucos remanescentes sofrem intensa pressão antrópica pela expansão das cidades costeiras, caça e exploração excessiva de recursos florestais (PRBMA, 2013).

\subsubsection{Floresta Ombrófila Mista Montana}

Esta formação, encontrada atualmente em poucas reservas particulares e no Parque Nacional do Iguaçu, ocupava quase que inteiramente o planalto acima dos $500 \mathrm{~m}$ de altitude, nos Estados do Paraná, Santa Catarina e Rio Grande do Sul. Porém, na década de 50, nas grandes extensões de terrenos situados entre as cidades de Lajes (SC) e Rio Negro (PR), podia-se observar Araucária angustifólia, ocupando e emergindo da submata de Ocotea 
pulchella e Ilex paraquariensis acompanhada por Cryptocarya aschersoniana e Nectandra megapotanica. Ao norte do Estado de Santa Catarina e ao sul do Paraná o "pinheiro-doparaná" estava associado com a imbuia (Ocotea porosa), formando agrupamentos característicos. Atualmente estes grandes agrupamentos desapareceram, substituídos pela monocultura de soja e trigo, intercaladas. Na década de 20, consideráveis disjunções de Araucaria, existentes no Vale do Rio Itajaí-Açu, associadas à Ocotea catharinensis, foram quase inteiramente devastadas, restando pequenos remanescentes sem expressão paisagística e econômica (Veloso et al., 1991).

\subsubsection{Terrenos Marinhos Lodosos}

Também conhecido como Manguezal. O manguezal é a comunidade microfanerofítica de ambiente salobro, situada na desembocadura de rios e regatos de mar, onde, nos solos limosos (manguitos), cresce uma vegetação especializada, adaptada à salinidade das águas, com a seguinte seqüência: Fhizophora mangle, Avicennia, cujas espécies variam conforme a latitude norte e sul e a Laguncularia racemosa, que cresce nos locais mais altos, só atingidos pela preamar. Nesta comunidade pode faltar um ou mesmo dois desses elementos. É frequente observar-se o manguezal só de Rhizophora como o do Maranhão ou só de Avicennia como o do Amapá e Santa Catarina, pois a Laguncularia só aparece quando existe terreno firme nos terraços e nas planícies salobras do fundo das baías e dos rios.

Em algumas dessas planícies, justamente quando a água do mar fica represada pelos terraços dos rios, a área salobra é densamente povoada por Gramineae do gênero Spartina e pela Salicornia portulacoides que imprimem ao "campo salino" o caráter de um "manguezal camefítico" (Manual técnico da vegetação brasileira, 1991).

\subsubsection{Formação Arbórea/Arbustiva-herbácea em Região de Várzea}

A composição florística desta formação é preferencialmente constituída por ecótipos higrófitos deciduais, adaptados ao ambiente aluvial, onde dominam mesofanerófitos, tais como: Luehea divaricata (açoita cavalo), Vitex megapotamica (tarumã), Inga uruguensis (ingá), Ruprechtia rariflora (farinha-seca) e a nanofanerófita Sebastiania commersoniana (branquilho) e outras (Manual técnico da vegetação brasileira, 1991). 
Nas Tabelas 6 e 7, para cada um dos municípios integrantes da Região Administrativa de Registro, são apresentadas as respectivas categorias de vegetação levantadas, correspondentes quantificações e evolução comparada com a variação da população nos períodos considerados. Os resultados mostraram uma tendência à estabilização entre os períodos 2000-2001 e 2004-2005, após uma recuperação da área de vegetação natural indicada pela análise dos dados referentes aos períodos 1990-1991 e 2000-2001 (Instituto Florestal, 2007). 
Tabela 6. Categorias de vegetação presente nos municípios da Região Administrativa de Registro.

\begin{tabular}{|c|c|c|c|c|c|c|c|c|c|c|c|c|c|c|}
\hline \multirow{3}{*}{ CLASSES } & \multicolumn{2}{|c|}{ BT } & \multicolumn{2}{|c|}{ CJ } & \multicolumn{2}{|c|}{$\mathrm{CN}$} & \multicolumn{2}{|c|}{ EL } & \multicolumn{2}{|c|}{ IG } & \multicolumn{2}{|c|}{ IL } & \multicolumn{2}{|c|}{ IT } \\
\hline & 2000-01 & 2004-05 & 2000-01 & 2004-05 & 2000-01 & 2004-05 & 2000-01 & 2004-05 & 2000-01 & 2004-05 & 2000-01 & 2004-05 & 2000-01 & 2004-05 \\
\hline & \multicolumn{2}{|c|}{ (área em ha) } & \multicolumn{2}{|c|}{ (área em ha) } & \multicolumn{2}{|c|}{ (área em ha) } & \multicolumn{2}{|c|}{ (área em ha) } & \multicolumn{2}{|c|}{ (área em ha) } & \multicolumn{2}{|c|}{ (área em ha) } & \multicolumn{2}{|c|}{ (área em ha) } \\
\hline 1 & $45.972,0$ & $45.712,1$ & $8.962,9$ & $8.955,7$ & $4.481,4$ & $4.481,4$ & $9.628,7$ & $9.628,7$ & $7.303,7$ & $7.301,8$ & --- & --- & $3.855,9$ & $3.855,9$ \\
\hline 2 & $1.178,9$ & $1.178,9$ & $2.895,2$ & $2.842,1$ & $41.035,3$ & $41.014,8$ & $9.045,0$ & $9.034,2$ & $25.756,5$ & $25.741,3$ & --- & --- & $3.783,1$ & $3.783,1$ \\
\hline 3 & --- & --- & 23,5 & 23,5 & $16.716,2$ & $16.963,8$ & 747,3 & 747,3 & $16.126,6$ & $16.102,0$ & --- & --- & 44,2 & 44,2 \\
\hline 4 & 568,3 & 562,8 & --- & --- & --- & --- & $80.935,3$ & $80.930,2$ & --- & --- & --- & --- & --- & --- \\
\hline 5 & 91,7 & 91,7 & --- & --- & --- & --- & --- & --- & --- & --- & --- & --- & --- & --- \\
\hline 6 & --- & --- & --- & --- & $9.036,6$ & $9.036,3$ & --- & --- & $1.742,9$ & $1.742,9$ & 988,5 & 988,5 & --- & --- \\
\hline 7 & $2.359,1$ & $2.359,1$ & --- & --- & --- & --- & 133,7 & 133,7 & $14.522,1$ & $14.505,2$ & $10.586,7$ & $10.574,6$ & --- & --- \\
\hline 8 & --- & --- & --- & --- & $23.446,9$ & $23.441,2$ & --- & --- & $64.275,4$ & $64.238,9$ & --- & --- & 12,1 & 12,1 \\
\hline 9 & $6.919,2$ & $7.141,1$ & $2.126,2$ & $2.119,2$ & 93,4 & 93,4 & $3.012,2$ & $3.012,2$ & 242,2 & 241,0 & --- & --- & $1.126,8$ & $1.126,8$ \\
\hline 10 & $4.137,5$ & $4.122,6$ & $5.580,3$ & $5.527,1$ & $5.131,1$ & $5.117,5$ & $23.785,5$ & $23.768,2$ & $5.747,7$ & $5.720,5$ & --- & --- & $7.325,2$ & $7.325,2$ \\
\hline 11 & --- & --- & 76,6 & 76,6 & 1588,9 & $1.588,9$ & $1.065,5$ & $1.065,5$ & $18.415,8$ & $18.242,1$ & --- & --- & 689,6 & $6.896,0$ \\
\hline 12 & $3.557,5$ & $3.565,7$ & 19,3 & 19,3 & --- & --- & 75,8 & 75,8 & --- & --- & --- & --- & --- & --- \\
\hline 13 & 120,5 & 114,6 & --- & --- & --- & --- & --- & --- & --- & --- & --- & --- & --- & --- \\
\hline TOTAL & $64.904,7$ & $64.848,6$ & $19.684,0$ & $19.563,5$ & $101.529,8$ & $101.737,3$ & $128.429,0$ & $128.395,8$ & $154.132,9$ & $153.835,7$ & $11.575,2$ & $11.563,1$ & $16.836,9$ & $23.043,3$ \\
\hline
\end{tabular}

Fonte: (Instituto Florestal, 2007).

1 - Floresta Ombrófila Densa Montana

2 - Floresta Ombrófila Densa Submontana

3 - Floresta Ombrófila Densa das Terras Baixas

4 - Floresta Ombrófila em Contato Floresta Ombrófila/Floresta Ombrófila Mista Montana

5 - Floresta Ombrófila Mista Montana

6 - Formação Arbórea/Arbustiva-herbácea de Terrenos Marinhos Lodosos

7 - Formação Arbórea/Arbustiva-herbácea em Região de Várzea

8 - Formação Arbórea/Arbustiva-herbácea sobre Sedimentos Marinhos Recentes

9 - Vegetação Secundária da Floresta Ombrófila Densa Montana

10 - Vegetação Secundária da Floresta Ombrófila Densa Submontana

11 - Vegetação Secundária da Floresta Ombrófila Densa das Terras Baixas

12 - Vegetação Secundária da Floresta Ombrófila em Contato Floresta Ombrófila/Floresta Ombrófila Mista Montana

13 - Vegetação Secundária da Floresta Ombrófila Mista Montana
BT - Barra do Turvo

CJ - Cajati

CN - Cananéia

EL - Eldorado

IG - Iguape

IL - Ilha Comprida

IT - Itariri 
Tabela 7. Categorias de vegetação presente nos municípios da Região Administrativa de Registro.

\begin{tabular}{|c|c|c|c|c|c|c|c|c|c|c|c|c|c|c|}
\hline \multirow{3}{*}{ CLASSES } & \multicolumn{2}{|c|}{ BT } & \multicolumn{2}{|c|}{ CJ } & \multicolumn{2}{|c|}{$\mathrm{CN}$} & \multicolumn{2}{|c|}{ EL } & \multicolumn{2}{|c|}{ IG } & \multicolumn{2}{|c|}{ IL } & \multicolumn{2}{|c|}{ IT } \\
\hline & 2000-01 & 2004-05 & 2000-01 & 2004-05 & 2000-01 & 2004-05 & 2000-01 & 2004-05 & 2000-01 & 2004-05 & 2000-01 & 2004-05 & 2000-01 & 2004-05 \\
\hline & \multicolumn{2}{|c|}{ (área em ha) } & \multicolumn{2}{|c|}{ (área em ha) } & \multicolumn{2}{|c|}{ (área em ha) } & \multicolumn{2}{|c|}{ (área em ha) } & \multicolumn{2}{|c|}{ (área em ha) } & \multicolumn{2}{|c|}{ (área em ha) } & \multicolumn{2}{|c|}{ (área em ha) } \\
\hline 1 & $3.099,9$ & $3.099,9$ & 251,0 & 251,0 & $2.313,8$ & $2.313,8$ & 3,9 & 3,9 & $10.847,4$ & $10.847,4$ & --- & --- & 1,1 & 1,1 \\
\hline 2 & $19.674,7$ & $19.609,3$ & $5.706,4$ & $5.694,4$ & $7.559,9$ & $7.507,7$ & $1.139,4$ & $1.128,4$ & $35.080,2$ & $35.093,3$ & $2.420,8$ & $2.420,8$ & $9.713,6$ & $9.697,2$ \\
\hline 3 & 883,9 & 869,7 & $1.418,8$ & $1.418,8$ & 404,0 & 400,3 & $5.679,0$ & $5.678,4$ & 554,0 & 554,0 & $2.729,9$ & $2.729,9$ & $4.939,9$ & $4.935,4$ \\
\hline 4 & --- & --- & $27.894,0$ & $27.867,1$ & --- & --- & --- & --- & 0,5 & 0,5 & --- & --- & $42.394,8$ & $42.390,6$ \\
\hline 5 & --- & --- & --- & --- & $40.436,0$ & $40.382,5$ & --- & --- & --- & --- & --- & --- & --- & --- \\
\hline 6 & --- & --- & --- & --- & --- & --- & --- & --- & --- & --- & --- & --- & --- & --- \\
\hline 7 & --- & --- & $1.671,3$ & $1.666,9$ & 329,3 & 329,3 & $1.971,2$ & $1.971,2$ & 547,6 & 547,6 & $2.965,1$ & $2.815,5$ & $5.959,3$ & $5.955,8$ \\
\hline 8 & --- & --- & --- & --- & --- & --- & --- & --- & --- & --- & --- & --- & --- & --- \\
\hline 9 & 921,6 & 921,6 & $2.312,1$ & $2.312,1$ & $6.650,4$ & $6.615,5$ & --- & --- & $6.502,5$ & $6.502,5$ & --- & --- & 40,5 & 40,5 \\
\hline 10 & $14.219,1$ & $14.135,8$ & $13.967,6$ & $13.933,0$ & $13.567,4$ & $13.480,2$ & $2.733,4$ & $2.683,1$ & $6.960,8$ & $6.955,1$ & $10.132,7$ & $10.121,3$ & $7.196,6$ & $7.187,3$ \\
\hline 11 & $2.033,0$ & $1.985,8$ & $4.140,7$ & $4.177,8$ & 1489,9 & $1.489,9$ & $8.193,7$ & $8.147,0$ & 298,0 & 298,0 & $12.700,3$ & $12.695,2$ & $4.409,7$ & $4.376,3$ \\
\hline 12 & --- & --- & 279,7 & 277,7 & 621,1 & 621,1 & --- & --- & --- & --- & --- & --- & $1.873,9$ & $1.873,9$ \\
\hline 13 & --- & --- & --- & --- & --- & --- & --- & --- & --- & --- & --- & --- & --- & --- \\
\hline TOTAL & $40.832,2$ & $40.622,1$ & $57.641,6$ & $57.598,8$ & $73.371,8$ & $73.140,3$ & $19.720,6$ & $19.612,0$ & $60.791,0$ & $60.798,4$ & $30.948,8$ & $30.782,7$ & $76.529,4$ & $76.458,1$ \\
\hline
\end{tabular}

Fonte: (Instituto Florestal, 2007).

1 - Floresta Ombrófila Densa Montana

2 - Floresta Ombrófila Densa Submontana

3 - Floresta Ombrófila Densa das Terras Baixas

4 - Floresta Ombrófila em Contato Floresta Ombrófila/Floresta Ombrófila Mista Montana

5 - Floresta Ombrófila Mista Montana

6 - Formação Arbórea/Arbustiva-herbácea de Terrenos Marinhos Lodosos

7 - Formação Arbórea/Arbustiva-herbácea em Região de Várzea

8 - Formação Arbórea/Arbustiva-herbácea sobre Sedimentos Marinhos Recentes

9 - Vegetação Secundária da Floresta Ombrófila Densa Montana

10 - Vegetação Secundária da Floresta Ombrófila Densa Submontan

11 - Vegetação Secundária da Floresta Ombrófila Densa das Terras Baixas

12 - Vegetação Secundária da Floresta Ombrófila em Contato Floresta Ombrófila/Floresta Ombrófila Mista Montana

13 - Vegetação Secundária da Floresta Ombrófila Mista Montana
JC - JACUPIRANGA

JU - JUQUITIBA

MI - MIRACATU

PA - PARIQUERA-AÇU

PT - PEDRO DE TOLEDO

RE - REGISTRO

ST - SETE BARRAS 


\subsection{Declividade}

A bacia do Ribeira insere-se num relevo bastante movimentado, com declividades que variam de zero a 80 graus, pertencendo em termos geomorfológicos na sua maior parte à Província Costeira (Almeida, 1964), a qual limita-se com o Planalto Atlântico através dos divisores das serras do Mar e de Paranapiacaba.

É interessante notar que o limite da Província Costeira com o Planalto Atlântico é mais nítido no litoral norte, onde a Serra do Mar é nitidamente uma escarpa de falha recuada (Almeida, 1976, Almeida e Carneiro, 1998), enquanto que no vale do Ribeira e litoral sul esse limite é recuado dezenas de quilômetros para dentro do continente, através da erosão regressiva do Ribeira. Alguns setores planálticos estão incluídos na área da bacia, como os planaltos de Alto Turvo, da Tapagem, parte dos planaltos de Guapiara, Ibiúna, Paulistano e outros menores. O mapa de declividades da UGRHI-11 está na Figura 9, e relevo pode ser visualizado na Figura 10.

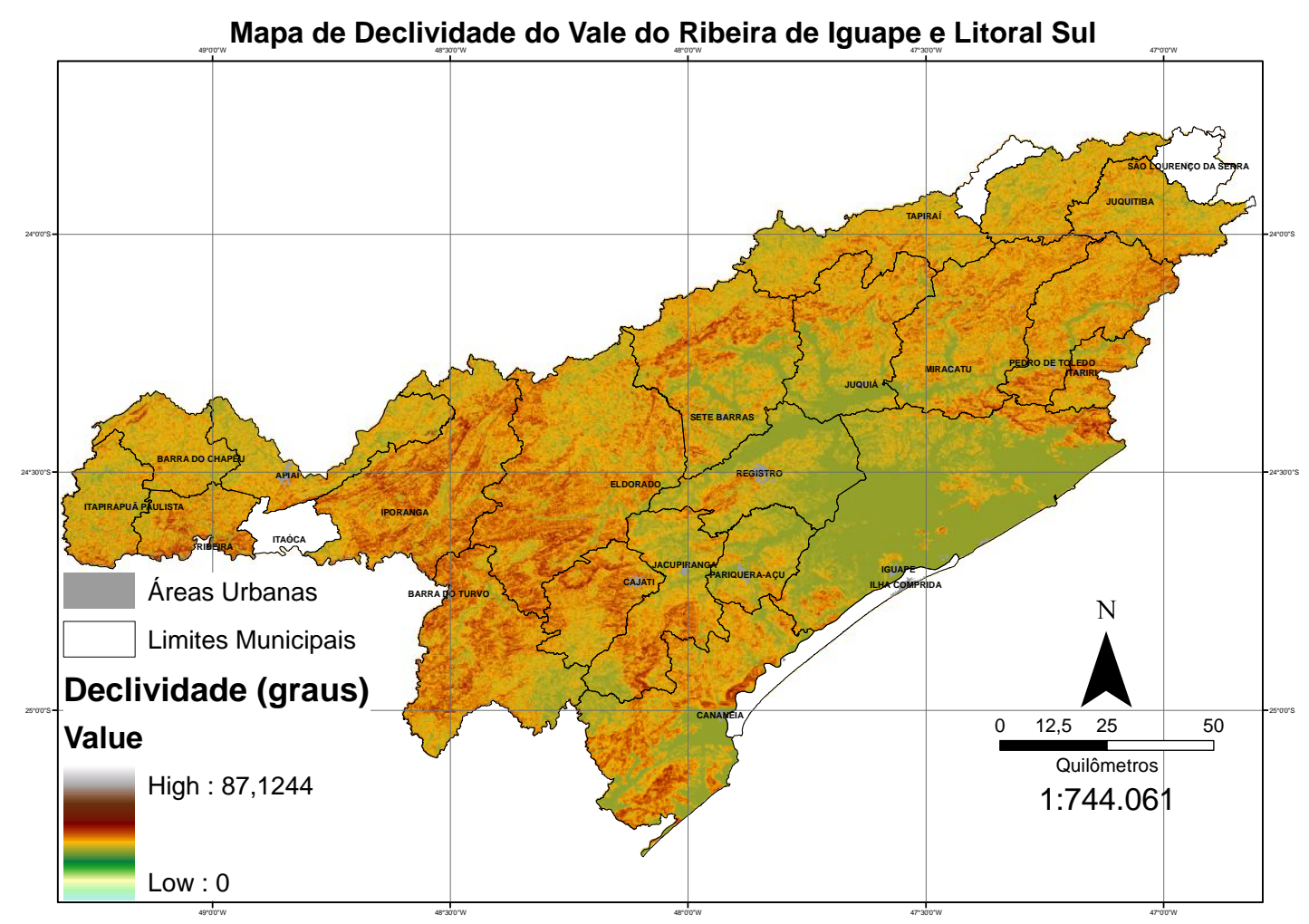

Figura 9. Mapa de declividade do Vale do Ribeira do Iguape e Litoral sul. 


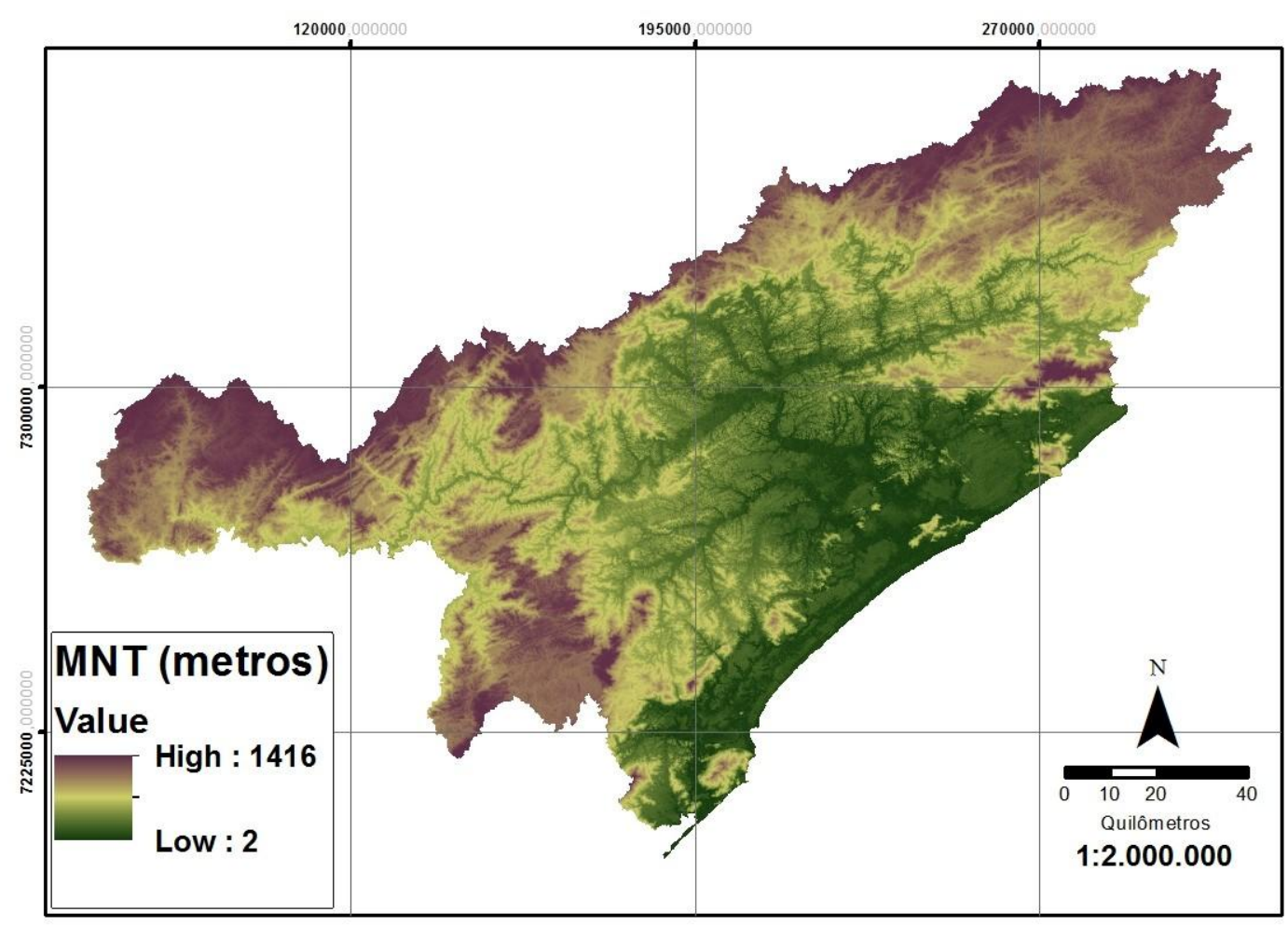

Figura 10. Modelo Numérico de Terreno do Vale do Ribeira do Iguape e Litoral sul.

\section{REVISÃO BIBLIOGRÁFICA}

\subsection{Suscetibilidade a erosão e escorregamentos no Vale do Ribeira do Iguape e}

\section{Litoral Sul}

No âmbito da fragilidade, é uma região sensível não só nos aspectos da biodiversidade, mas também em relação aos processos geomorfológicos, pois se trata de ambiente extremamente propício aos processos erosivos de todos os tipos, bem como altamente susceptível aos processos de deslizamentos ou escorregamentos de solo e rocha e rolamentos de blocos.

Os problemas relativos à erosão e deslizamentos encontram-se presentes em vários lugares do mundo, mas em países cujo regime pluvial tem as características do ambiente tropical e cuja situação socioeconômica seja considerada como de subdesenvolvimento ou em desenvolvimento, os problemas tornam-se mais acentuados devido à escassa estrutura para evitar ou controlar tal fenômeno (Guerra, 1994).

Os fenômenos de erosão e deslizamentos já foram bastante estudados e medidas preventivas e corretivas são recomendadas pelo meio técnico. Todavia, acidentes 
relacionados a estes processos, infelizmente, ainda ocorrem em larga escala. Exemplos recentes e de grande impacto na mídia foram em Angra dos Reis (Estado do Rio de Janeiro), em janeiro de 2010; na região serrana do Rio de Janeiro, em janeiro de 2011; e no Vale do Itajaí (Estado de Santa Catarina), em novembro de 2008 e setembro de 2011. Em todos os casos houve vítimas fatais.

Dessa forma, mostram-se necessárias medidas de caráter preventivo e/ou corretivo para evitar acidentes com morte e, se não anular, mitigar os danos materiais. Uma destas medidas é o uso do mapeamento geotécnico, processo que busca avaliar e retratar as características dos componentes do meio físico, bem como os possíveis comportamentos frente às diferentes formas de uso do solo, processos naturais e induzidos (Zuquette, 2004).

Cartas de vulnerabilidade à erosão e a movimentos de massa, produtos de mapeamento geotécnico, são importantes ferramentas para auxiliar os planos diretores, evitar futuras instalações de imóveis em locais de risco geológico e alocar pessoas em áreas de risco.

\subsection{Simulação de cenários futuros}

Pensar acerca do percurso do Homem e do seu desenvolvimento holístico enquanto pessoa coloca a necessidade de se compreender como foi o caminho das diferentes sociedades e comunidades, de forma a tomar-se decisões informadas para que exista uma evolução sustentada. Assim, através da interpretação de dados históricos é possível traçar os diferentes cenários quer face ao Passado que se estuda, ao Presente que se possui e ao Futuro que se deseja (Gago, 2007).

Diversas experiências têm mostrado que a construção de cenários auxilia o grupo de planejamento a modificar e ajustar o seu olhar sobre o espaço, o tempo e o meio, induzindo a uma maior compreensão dos problemas prioritários e levando a soluções comuns. Clavero et. al (2010) descrevem que a grande utilidade dos cenários futuros é o fato de servirem como ferramentas para a tomada de decisões, que possam afetar de forma regional fatores sociais e ambientais. A modelagem de cenários é um método que possibilita o estudo da dinâmica das mudanças de uso do solo. Com este modelo é possível simular a dinâmica da paisagem ao futuro, tendo como base alguns cenários estabelecidos (Kok et. al, 2007 apud Clavero et al., 2010). 
Os estudos de cenários futuros não devem ser considerados como o final de um processo de gestão, mas um meio para incentivar a tomada de decisões. Os cenários são guias que descrevem caminhos alternativos até um futuro possível baseado em hipóteses razoáveis. São construções intelectuais que ajudam a compreender o que pode ocorrer, não o que vai ocorrer, nem o que deve ocorrer ou o que os gestores querem que ocorra. A forma nas quais se distribuem os usos do solo será a base da evolução da sociedade, que constitui um elemento de primeira ordem na busca por uma situação ambiental futura mais adequada possível (Clavero et al., 2010).

O processo de urbanização, agente que exerce forte pressão sobre a distribuição do uso e ocupação do solo, é impulsionado pelo crescimento econômico, industrialização, desenvolvimento agrícola e o aumento da população urbana. À medida que há aumento da proporção de habitantes nas cidades, consequentemente, há incremento no número e tamanho de áreas urbanizadas, algumas vezes se sobrepondo às áreas naturais ou com valor produtivo, normalmente sem um padrão de crescimento e condicionado ao meio físico (topografia e rios) e a fatores socioeconômicos e políticos (legislação e preço dos terrenos), que interagem entre si (Antrop, 2004). A urbanização possui vários efeitos sobre a estrutura e funcionamento dos ecossistemas, modificando as coberturas naturais do solo e, em alguns casos, o impermeabilizando com coberturas artificiais. A partir do conhecimento destes efeitos surge a necessidade de desenvolver e implementar estratégias de planejamento urbano que partam de um melhor conhecimento dos padrões espaciais, as causas e impactos da urbanização e os fatores que regem o crescimento urbano para determinadas zonas (Angonese et al., 2010).

A simulação de cenários futuros de uso e ocupação do solo e processo de urbanização é uma importante ferramenta para avaliar desenvolvimentos futuros em sistemas complexos que possuem um grande número de incertezas, e por isso é uma técnica adequada para gestão e planejamento, por exemplo, de zonas costeiras. Os cenários permitem integrar modelos sócio-econômicos com modelos físicos, químicos ou biológicos, refletir sobre tendências e dinâmicas e trabalhar com diferentes escalas temporais e espaciais (Carrero et al., 2010). A elaboração de cenários visa à apresentação das tendências de evolução de longo prazo (MMA, 2006). 


\subsubsection{Projetos com simulação de cenários}

Vieira (2010) desenvolveu o projeto de doutorado "Conservação ambiental em cenários de uso: medidas de mudanças, heterogeneidade e valoração da paisagem", onde utilizou a metodologia de cenários com objetivo de verificar se as mudanças ocorridas numa área de proteção ambiental da Serra do Japi (Estado de São Paulo), evoluíram em direção às expectativas da conservação ou de uso, com o uso do programa ArcGIS, versão 9.2 (ESRI, 2008). Conclui que as mudanças ocorridas nessa área com proteção legal ambiental evoluíram em direção às expectativas da conservação, mas não na configuração de florestas esperada pelos atos ambientais legais. Dessa forma, a perspectiva proposta para a construção de cenários pode auxiliar na tomada de decisão em processos participativos, principalmente quando ocorre a espacialização das expectativas e sua comparação com outros cenários, o que ajuda na proposição de cenários futuros consensuais que busquem estabelecer a conservação ambiental e sua partilha social.

Terra (2010), em seu projeto de mestrado "Efeitos cumulativos e a construção de cenários em paisagens legalmente protegidas", trabalhou com cenários com o objetivo de interpretar o acúmulo de ações antrópicas, no decorrer de quarenta e cinco anos, e estimar os possíveis efeitos dos prováveis impactos, para o ano 2028. A área de estudo é localizada no litoral sul do estado de São Paulo e compreende a Reserva de Desenvolvimento Sustentável de Despraiado, Estação Ecológica Juréia-Itatins e zona de amortecimento limítrofe a essas duas regiões.

Terra (2010) cita que os Sistemas de Informações Geográficas (SIG) são importantes ferramentas para auxiliar na avaliação de efeitos cumulativos, pois permitem interpretar as sobreposições das mudanças da paisagem que ocorrem numa mesma área. Porém, para uma ampla análise da evolução destas mudanças e a possibilidade de fazer previsões, o SIG deve estar aliado ao sistema de cenários. O método da simulação da paisagem foi construído no SIG Idrisi Andes (Eastman, 2006) a partir da sequência de funções; cadeias de Markov, calibração do modelo de simulação e cadeias de Markov acoplados a um algoritmo de autômato celular. A conclusão desta pesquisa foi que o cenário simulado para 2028 sugere que, se a condição histórica de uso da terra e atuação do Estado continuar na mesma tendência dos últimos 45 anos, as áreas fronteiriças à Estação Ecológica, Reserva de Desenvolvimento Sustentável e Zona de Amortecimento não terão uma cobertura vegetal natural superior a $10 \%$, mas serão 
compostas por $43 \%$ de bananais e por $33 \%$ de bananais inseridos em florestas. Em termos de evolução de quantidade de vegetação natural, a Reserva de Desenvolvimento Sustentável de Despraiado é a região mais privilegiada, pois no cenário simulado será essa área de fronteira a de melhor estado futuro de conservação florestal. No entanto, em termos de concentração de efeitos acumulados seus valores são piores do que a Estação Ecológica, que apresenta, neste aspecto, o melhor cenário.

$\mathrm{Na}$ pesquisa "Implementación de un sistema de escenarios futuros sobre el mapa de usos de suelo de Andalucía", os autores desenvolveram um projeto para explorar e analisar a evolução do uso do solo num contexto de mudanças segundo diferentes cenários, utilizando mapas de uso e coberturas vegetais do solo da Andalucía (Espanha), com o objetivo de desenvolver cenários futuros para prever a mudança no uso do solo num período de 30 anos. Utilizou-se o modelo METRONAMICA, que permite explorar tanto aspectos econômicos quanto ambientais através de um processo de Autômatos Celulares. A idéia básica dos autômatos celulares é que a condição de um pixel é relativa às células vizinhas (vizinhança). O objetivo final do modelo é atribuir um tipo de uso e ocupação do solo para cada pixel do mapa para simular o comportamento dinâmico do uso da terra. O processo de atrbuição é baseado num algoritmo que indica o potencial de determinado pixel, que depende dos pixeis vizinhos (Clavero et al., 2010).

Neste estudo, Clavero et al. (2010) optaram por considerar os cenários descritos no projeto europeu PRELUDE (Prospective Environmental Analysis of Land Use Development in Europe), no qual pesquisadores das áreas de economia, demografia, indústria e meio ambiente, baseando-se em diferentes hipóteses, como mudanças climáticas, ambientais, econômicas, sociais e tecnológicas, desenvolveram cinco cenários qualitativos, onde em cada um se refletiam as mudanças ocorridas no uso do solo e os impactos causados no meio ambiente. Porém, houve a adequação dos cenários para Andaluzía, de forma que algumas forças motrizes foram incorporadas ao sistema, enquanto outras eliminadas. Os autores finalizam o artigo citando que a pesquisa não está concluída, pois está em fase de desenvolvimento da integração dos cenários com as forças motrizes que os caracterizam e as informações cartográficas e estatísticas relacionadas à Andaluzía.

Angonese et al. (2010) combinaram técnicas de Avaliação Multi-critérios e Sistemas de Informações Geográficas para gerar um modelo de ocupação urbana desejável para o período compreendido entre 2001 e 2009 e compará-lo com o 
crescimento real neste período, avaliando diferentes cenários de crescimento urbano desejáveis, considerando critérios sociais, econômicos e ambientais. A região de estudo é a Gran San Miguel de Tucumán, situada na região nordeste da Argentina. Foi utilizado um modelo digital de elevação e imagens do sensor TM (referente a 2001 e 2009) para a elaboração do mapa urbano, que considera como "urbano" a superfície com densidades média e alta de edificações. Paralelamente, foram criados mapas referentes aos fatores relevantes ao problema analisado: malha viária primária e secundária; hidrografia; unidades de conservação; centros comerciais, educacionais e de saúde; estações de tratamento de esgoto, aterros de resíduos e cemitérios. A avaliação multi-critério (AMC) foi realizada através de ponderação dos fatores envolvidos e posterior combinação linear ponderada.

Dessa forma, elaboraram-se diferentes mapas de adequação urbana, que representam cenários alternativos de ocupação desejável da área urbana, os quais foram elaborados através de diferentes processos de ponderação dos fatores envolvidos na AMC. Foram criados cinco cenários: o de comprometimento, onde os pesos dos fatores foram distribuídos equitativamente entre fatores ambientais e econômicos; o ambiental, onde fatores ambientais receberam maiores pesos; o econômico, com maiores pesos aos fatores econômicos; e os cenários extremos, onde foram incluídos somente fatores ambientais ou econômicos. Os cenários propostos apresentaram valores de adequação média maiores que os observados no crescimento urbano real. Em geral, as áreas desejáveis para o uso urbano segundo os diferentes cenários localizam-se a leste da região de Gran San Miguel de Tucumán. Porém, o crescimento real se observa em direção à região central da área de estudo, seguindo as principais vias de transporte, padrão semelhante ao cenário econômico extremo, evidenciando a influência da malha viária na localização das áreas residenciais e a carência de critérios de preservação ambiental no estabelecimento das zonas urbanas (Angonese et al., 2010).

Machado et al. (2003) desenvolveram um projeto que simulou cenários alternativos de uso e ocupação da terra na microbacia hidrográfica do Ribeirão dos Marins, situada em Piracicaba (São Paulo), com o objetivo de compará-los com o uso real, em relação à produção de sedimentos. Este trabalho avaliou a distribuição espacial da produção de sedimentos nessa microbacia, por meio da integração do modelo SWAT (Soil and Water Assessment Tool) com o programa ArcGIS versão 9.3 (ESRI, 1998), e comparou os resultados gerados pelo modelo com os dados obtidos por um posto hidrossedimentométrico, no período de 1999 a 2000. 
Dois cenários foram criados com o objetivo de exemplificar a aplicação e a integração de modelos hidrológicos e de qualidade de água com SIG para avaliar opções de uso da terra em microbacias hidrográficas. Para diferenciar ambos cenários, foi feita uma variação no plano de informação (layer) de uso e ocupação da terra. Os cenários avaliados foram:

a) Cenário 1. Baseou-se no uso e ocupação da terra real, porém respeitando duas regras do Código Florestal (Lei nº7875 de 1989), o estabelecimento de área de proteção ao redor dos corpos de água e nascentes. Assim, criou-se um "buffer" de 30 metros para representar a largura mínima de proteção a florestas situadas ao longo dos cursos de água, da área de estudo; e outro "buffer" de 50 metros de raio para as nascentes. Assim, esses "buffers" foram sobrepostos à imagem de uso e ocupação real da terra, no ano 2000.

b) Cenário 2. As florestas e demais formas de vegetação natural situadas nas encostas ou partes destas com declive superior a $45^{\circ}(100 \%)$, na linha de maior declive, foram consideradas Áreas de Proteção Permanente. Neste cenário, as pastagens que ocupam as encostas mais íngremes foram substituídas por vegetação florestal nativa.

Com a passagem do cenário real para o cenário 1 , houve uma diminuição nas áreas ocupadas por cana-de-açúcar e pastagem e um ganho na área ocupada por vegetação nativa. No cenário 2, a área ocupada por cana-de-açúcar não sofreu alteração porque esta cultura situava-se nas encostas menos íngremes, assim, não precisou ser substituída. Porém, no cenário 1, a área ocupada por vegetação nativa passou a ocupar $41,23 \%$ da bacia contra os $8,10 \%$ do cenário de uso real, já que passou a ocupar toda a área antes ocupada por pastagens. Comparando os resultados do cenário real com os dois cenários modelados, o modelo diminui a perda de solo no cenário 1. Esse dado pode ser explicado pelo fato de estando a mata ciliar em bom estado de preservação, infere-se que esta atuaria como uma barreira de proteção aos sedimentos, principalmente no sentido de reduzir a velocidade de escoamento e reter parte dos sedimentos. De maneira semelhante, no cenário 2, a perda de solo foi ainda menor, em relação ao cenário real, já que é esperado que a vegetação nativa possa diminuir a erosão, uma vez que altera diretamente os parâmetros de infiltração e especialmente a proteção dada ao solo contra o impacto direto das gotas de chuva e aumento da rugosidade superficial (Machado et al., 2003). 


\subsection{Vulnerabilidade Costeira}

Como já citado, a UGRHI-11, a leste, possui uma testada de $140 \mathrm{~km}$ para o Oceano Atlântico, o que demanda alguns cuidados, principalmente em relação à vulnerabilidade costeira diante a uma potencial elevação do nível do mar. Esta área litorânea do Vale do Ribeira é chamada de Complexo Estuarino Cananeia-Iguape, que também é composta pelo município de Ilha Comprida. Está entre as regiões mais preservadas do litoral brasileiro e, por ser extremamente vulnerável, encontra-se sob a jurisdição de um mosaico de Unidades de Conservação. Em 1993, a região foi reconhecida como Reserva da Biosfera da Mata Atlântica e, em 1999, recebeu o título de Patrimônio Natural da Humanidade, conferido pela UNESCO (CPLA, 2013). É, portanto, uma unidade ambiental de absoluto interesse à preservação e conservação ambiental (Ross, 2002).

Desde 1992 existe a possibilidade de medir o nível médio do mar a partir de altímetros acoplados em satélites (Topex/Poseidon, Janson). Os trabalhos publicados proporcionam taxas anuais de $3.1 \mathrm{~mm}$, com variação para cima ou para baixo de $0.7 \mathrm{~mm}$ (IPCC, 2007). Além das medições, tem sido observado aumento da erosão marinha no litoral da área em estudo, com danos a construções nas áreas da Juréia e Ilha Comprida e modificações da linha da costa na Ilha do Cardoso (Júnior el al., 2008).

Para o próximo século as taxas de elevação continuarão a aumentar, podendo atingir valores que duplicariam as taxas registradas no século 20, supondo elevações de $18 \mathrm{~cm}$ até $59 \mathrm{~cm}$, para um cenário mais pessimista. Independente do cenário atingido, o nível do mar continuará em elevação com taxas entre 2 e $3 \mathrm{~mm}$ por ano durante a primeira metade do século 21. Os impactos desta elevação do nível do mar serão associados com o aumento da erosão costeira, processos de intrusão de água salgada nos estuários e aqüíferos costeiros ou o aumento do risco de inundação (Zújar, 1995; 2000; 2006; 2009).

Pelo fato da UGRHI-11 possuir um de seus limites com o oceano é importante que se faça uma avaliação dos possível danos causados por uma possível elevação do nível do mar. Este é um dos fatores que será agregado à criação dos cenários futuros do uso e ocupação do solo do Vale do Ribeira de Iguape e Litoral Sul do Estado de São Paulo. 


\section{OBJETIVOS}

O presente projeto tem os seguintes objetivos:

\subsection{Objetivos gerais}

- Elaboração de mapas de suscetibilidade a erosão e movimentos de massa no Vale do Ribeira do Iguape e Litoral Sul.

- Elaboração de mapas de uso e ocupação do solo da UGRHI-11 referentes aos anos 1986, 1999 e 2010.

- Modelagem da vulnerabilidade a um potencial aumento do nível do mar no Complexo Estuarino-Lagunar de Iguape-Cananéia.

- Confecção de cenários futuros para modelar as áreas (tamanho e localização) das classes de uso do solo da UGRHI-11, em 2025.

- Cruzamento do modelo vulnerabilidade a um potencial aumento do nível do mar e o cenário de uso e ocupação do solo (2025) no Complexo Estuarino-Lagunar de Iguape-Cananéia.

\subsection{Objetivos Específicos}

a) Elaboração de mapas de uso e ocupação do solo da UGRHI-11 referente a 1986, 1999 e 2010.

\section{Atividades:}

- Aquisição das cenas da série Land Remote Sensing Satellite (Landsat 5) de 1986 e 1987,1999 e 2010.

- Pré-processamento das cenas - ortorretificação e correção geométrica.

- Levantamento de campo para definição das classes a serem utilizadas na classificação supervisionada.

- Aplicação da classificação supervisionada.

Produtos: Mapas de usos e coberturas do solo da UGRHI-11 referentes a 1986, 1999 e 2010. 
b) Elaboração dos mapas de suscetibilidade a erosão e movimentos de massa na UGRHI-11.

Atividade 1:

- Aplicação do método Revised Universal Soil Loss Equation (RUSLE).

Produto 1: Mapa de suscetibilidade à erosão na UGRHI-11.

Atividade 2:

- Aplicação de Combinação Linear Ponderada como metodologia na elaboração do mapa de suscetibilidade a movimentos de massa na UGRHI-11.

Produto 2: Mapa de suscetibilidade a movimentos de massa na UGRHI-11.

c) Confecção de cenários futuros que abordem a distribuição das classes de uso e ocupação do solo na UGRHI-11, em 2025.

Atividades:

- Aplicação do método de cadeias de Markov acoplados ao autômato celular.

Produtos: Mapas de usos e coberturas do solo da UGRHI-11 referente ao ano 2025.

d) Cálculo dos índices de vulnerabilidade a um potencial aumento do nível do mar no Complexo Estuarino-Lagunar de Iguape-Cananéia.

Atividades:

- Aplicação dos métodos IPCC (Intergovernmental Panel on Climate Change), Ramhstorf, Pfeffer e Titus.

Produtos: Mapas referentes às áreas cobertas pela máxima preamar, para os anos 2025, 2050 e 2011 para o método de Titus e Narayanan; e 2100 para os métodos do IPCC, Ramhstorf e Pfeffer. 
e) Sobreposição das possíveis áreas cobertas pelo mar, em 2025 (método de Titus e Narayanan) sobre os cenários de uso do solo nos municípios de Cananéia, Ilha Comprida e Iguape.

Atividades:

- Recorte do cenário de uso do solo (2025) com os limites das áreas cobertas pelo nível da máxima preamar e análise qualitativa de quais tipos de classes de uso do solo serão atingidas e cálculo de área de cada classe atingida.

Produtos: Mapas com indicações das classes de uso do solo atingidas pelo nível do mar em 2025 e tabelas com informações das áreas atingidas.

Indicações de áreas para projetos urbanos futuros de expansão urbana e crescimento de área rural.

\section{MATERIAIS E MÉTODOS}

A descrição dos materiais e métodos utilizados em cada produto será apresentada nos capítulos:

- Capítulo 9 - Desenvolvimento e avaliação de um modelo de previsão de erosão e movimento de massa na bacia do Ribeira de Iguape e Litoral Sul do Estado de São Paulo.

- Capítulo 10 - Evolução do uso e ocupação do solo na UGRHI-11 entre 1986, 1999 e 2010.

- Capítulo 11 - Cálculo da suscetibilidade a um potencial aumento no nível do mar no Complexo Estuarino-Lagunar de Iguape-Cananéia.

- Capítulo 12 - Aplicação de geotecnologias na elaboração de cenários futuros de uso do solo do Vale do Ribeira de Iguape e Litoral Sul do Estado de São Paulo, para o ano 2025.

- Capítulo 13 - Indicação de classes de uso e ocupação do solo afetadas por um potencial aumento do nível do mar no ano 2025, no Complexo EstuarinoLagunar de Iguape-Cananéia. 


\section{DESENVOLVIMENTO E AVALIAÇÃo DE UM MODELO DE PREVISÃO DE EROSÃO E MOVIMENTO DE MASSA NA BACIA DO RIBEIRA DE IGUAPE E LITORAL SUL DO ESTADO DE SÃO PAULO}

\subsection{Introdução}

A metodologia utilizada neste estudo aborda técnicas de zoneamento geotécnico e análise de suscetibilidades (Becker and Egler, 1996; Ross, 2006b; Theodorovicz et al., 2007; Miranda et al., 2008). Ross (2006a) descreve como um procedimento operacional básico utilizado na espacialização de informações geoambientais, a Análise Multitemática que se caracteriza pela geração de produtos analíticos em uma primeira fase e, posteriormente, de síntese. Dessa forma, mapas de suscetibilidade a erosão e movimentos de massa na UGRHI11 foram produzidos a partir de uma análise integrada dos elementos do meio físico. Campanhas de trabalho de campo foram realizadas nas áreas com ocorrência tanto de erosão quanto de movimentos de massa. Todos dados de campo e pontos de controle foram obtidos com uso de um receptor DGPS (Diferencial Global Positioning System), respeitando-se os limites de exatidão exigidos à produtos cartográficos de Classe A (Decreto Federal 89.817). Os modelos altimétricos derivados destes dados também cumpriram as exigências de precisão. O mapeamento temático foi baseado em dados secundários e de campo em escala $1: 200.000$.

\subsection{Criação do mapa de vulnerabilidade a processos erosivos}

O uso de modelos de erosão tem sido recomendado aos trabalhos de previsão de estabilidade de relevo (Evans \& Loch, 1996). Wischmeier \& Smith (1965), desenvolveram a Equação Universal de Perda de Solo (USLE - Universal Soil Loss Equation), que é o mais utilizado de todos os modelos de erosão. Esta equação estima a perda de solo média anual, com dados relacionados a chuvas, solo, topografia e práticas conservacionistas. Ao modificar os fatores topográficos e na USLE e aplicar uma abordagem mais determinista para calcular o fator prática de apoio, Yoder et al. (1992) desenvolveram a Equação Universal de Perda de Solo Revisada (RUSLE), fator de práticas conservacionistas da USLE.

Em 1985 o Departamento de Agricultura dos Estados Unidos da América iniciou o WEPP (Water Erosion Prediction Project), um método capaz de prever a distribuição espacial e temporal de perdas de solo para qualquer período de tempo. Este método possui uma vasta gama de aplicabilidade, já que contém seu próprio processo baseado na hidrogeologia, 
equilíbrio hidráulico, crescimento das plantas, eliminação de resíduos, modelos de consolidação de solo, e clima (Tiwari et al., 2000).

Cecílio et al. (2004) desenvolveram um estudo na Bacia Hidrográfica de Viçosa, onde foi realizada uma comparação entre os modelos RUSLE e WEPP e concluíram que a perda de solo anual modelada pelo RUSLE foi muito similar à perda medida em campo. Risse et al. (1993) e Tiwari et al. (2000), em alguns estudos de comparação entre USLE, RUSLE e WEPP, feitos nos EUA demonstraram que USLE e RUSLE tiveram melhores resultados que WEPP.

De acordo com Ubierna et al. (2009), em trabalho de restauração de áreas mineradas, o método RUSLE superestima as médias de erosão. O oposto ocorre com os métodos USLE e WEPP, que tendem a subestimar a erosão em áreas com altas taxas de perda de solo, como nas áreas com alto grau de declividade. Dessa forma, os autores indicam que WEPP e USLE não são métodos úteis para terrenos de alta declividade. Em contraste, o método RUSLE é o que melhor ajusta os valores de erosão à realidade. Assim, concluem que o método RUSLE é o mais adequado entre os três.

Para a elaboração do mapa de suscetibilidade à erosão na UGRHI-11, a escolha da metodologia foi baseada na disponibilidade de dados. O fato da área de estudo ser grande e a dificuldade de adquirir dados suficientes para serem aplicados no método WEPP também influenciaram a escolha pelo RUSLE. A criação de um banco de dados a ser aplicado em RUSLE é relativamente simples. Além disso, RUSLE é um modelo mais apropriado para UGRHI-11 porque, de acordo com Ubierna et al. (2009), WEPP e USLE não são adequados para encostas caracterizadas por elevadas taxas de erosão. Assim, o mapa de suscetibilidade à erosão foi desenvolvido utilizando a Equação Universal de Perda de Solo Revisada (Eq. 1), com o auxílio do software IDRISI Andes, versão 15.01 (Eastman, 2006). Esta metodologia empírica desenvolvida por Wischmeier \& Smith (1958 e 1978) expressa a ação combinada de fatores naturais (erosividade da chuva, erodibilidade do solo e relevo) e antrópicos (uso do solo, manejo e práticas de conservação), que influenciam a RUSLE é representado da seguinte forma:

\section{A = R.K.L.S.C.P}

$\mathrm{A}=$ perda do solo calculada por unidade de área;

$\mathrm{R}=$ Erosividade da chuva: capacidade da chuva em causar erosão num solo sem proteção. É relacionada à energia cinética, intensidade de precipitação e lâmina total precipitada. 
$\mathrm{K}=$ Erodibilidade do solo: expressa a resistência do solo à erosão hídrica sendo dependente de atributos mineralógicos, químicos, morfológicos e físicos do solo.

$\mathrm{L}=$ Comprimento do declive: relação de perda de solo entre um comprimento de declive qualquer e um comprimento de rampa de 25 metros para o mesmo solo e grau de declive.

$\mathrm{S}=$ Grau de declive: relação de perda de solo entre um declive qualquer e um declive de $9 \%$ para o mesmo solo e comprimento de rampa.

$\mathrm{C}=$ Uso e manejo do solo: relação entre perda de solo de um terreno cultivado em dadas condições e as perdas correspondentes de um terreno mantido continuamente descoberto, isto é, nas mesmas condições em que o fator $\mathrm{K}$ é avaliado.

$\mathrm{P}=$ Práticas conservacionistas: relação entre as perdas de solo de um terreno cultivado com determinada prática e as perdas quando o cultivo é em morro abaixo.

Todos os parâmetros foram padronizados conforme o Sistema Internacional (Foster et al., 1981).

Este processo foi desenvolvido através da inserção dos dados de erosividade e erodibilidade na tabela de atributos do arquivo vetorial (shapefile) do mapa pedológico e posterior rasterização para gerar os mapas erosividade e erodibilidade, ambos os processos feitos no programa ArcMap (Esri, 2009), baseando-se em Bertoni \& Lombardi (1990).

A carta pedológica da UGRHI-11 utilizada foi elaborada por Lepsch et al. (1999), que utiliza a antiga legenda de solos do Mapa de 1960 o que, porém, não traz maiores problemas aos objetivos do presente trabalho, pois para os cálculos desenvolvidos no presente trabalho interessam a textura e estrutura das porções mapeadas e não seus nomes. Quando existentes, são citadas as atualizações do atual Sistema Brasileiro de Classificação de Solos (SBCS). Esta carta, na escala 1:250.000. 


\subsubsection{Erosividade da chuva (R)}

Os valores de erosividade foram calculados através da aplicação da equação proposta por Bertoni e Lombardi Neto (1990), demonstrada na Eq. 2.

$$
\text { Eq. } 2 \mathrm{EI}=6.886 \times\left(\mathrm{p}^{2} / \mathrm{P}\right)^{0.85}
$$

Onde:

$\mathrm{EI}=$ média mensal de erosão em $\mathrm{MJ} /$ ha-mm;

$\mathrm{r}=$ média pluviométrica mensal em milímetros;

$\mathrm{P}=$ média pluviométrica anual em milímetros.

Tanto os valores pluviométricos mensais quanto os anuais utilizados nesta equação foram obtidos dos dados TRMM (Tropical Rainfall Measuring Mission), referentes a janeiro de 2000 a julho de 2012 (totalizando 151 registros). Estas imagens TRMM foram recortadas com o limite da UGRHI-11 e vetorizadas, o que resultou em 24 pontos. A erosividade foi calculada para cada ponto, de acordo com Bertoni \& Lombardi Neto (1990). Assim, obtiveram-se as médias pluviométricas para cada um dos 24 pontos entre janeiro de 2000 e julho de 2012.

\subsubsection{Erodibilidade do solo $(K)$}

O fator erodibilidade do solo dimensiona a capacidade de um solo sofrer em maior ou menor grau os processos erosivos. As propriedades do solo que influenciam a erodibilidade são aquelas que afetam a velocidade de infiltração, permeabilidade e capacidade total de armazenamento de água, bem como resistências diferenciadas às forças de dispersão, salpico, abrasão e transporte pela chuva e escoamento (Liotte, 2000). Os valores de erodibilidade atribuídos para cada classe de solo foram retirados de Bertoni \& Lombardi (1990), visualizados na Tabela 8 . 
Tabela 8. Valores de erodibilidade atribuídos às classes de solos.

\begin{tabular}{lclc}
\hline \multicolumn{1}{c}{ Classe pedológica } & $\begin{array}{c}\text { Erodibilidade } \\
(\mathrm{t} . \mathrm{h} / \mathrm{MJ})\end{array}$ & \multicolumn{1}{c}{ Classe pedológica } & $\begin{array}{c}\text { Erodibilidade } \\
(\mathrm{t} . \mathrm{h} / \mathrm{MJ})\end{array}$ \\
\hline Brunizem Avermelhado & 0,0300 & Solo de Mangue & 0,0009 \\
Cambissolo Álico & 0,0350 & Solos Aluviais Distróficos & 0,0010 \\
Cambissolo Distrófico & 0,0350 & Solos Gleizados Álicos & 0,0011 \\
Cambissolo Eutrófico & 0,0350 & Solos Gleizados Distróficos & 0,0011 \\
Latossolo Amarelo Álico & 0,0133 & Solos Gleizados Tiomórficos & 0,0011 \\
Latossolo Variacão Una Distrofico ou Alico & 0,0133 & Solos Litolicos Álicos & 0,0008 \\
Latossolo Vermelho Amarelo Alico & 0,0133 & Solos Litolicos Distróficos & 0,0008 \\
Podzol & 0,0270 & Solos Organicos Álicos & 0,0011 \\
Podzolico Bruno Acizentado Eutrofico & 0,0180 & Solos Orgânicos Álicos Soterrados & 0,0011 \\
Podzolico Vermelho Amarelo Alico & 0,0400 & Solos Orgânicos Tiomórficos & 0,0011 \\
Podzolico Vermelho Amarelo Distrofico & 0,0396 & Terra Bruna Estruturada Distrófica & 0,0133 \\
\hline
\end{tabular}

\subsubsection{Comprimento e grau de declive (LS)}

Para Bertoni \& Lombardi Neto (1990) o fator LS é a associação dos fatores L e S. O mapa de declividade foi gerado a partir de um mapa topográfico, em escala 1:50.000, com cotas de 20 em 20 metros, que primeiramente foi rasterizado para um Modelo Numérico de Terreno, no ArcMap (Esri, 2009) e, posteriormente, transformado em mapa de declividade no módulo slope do IDRISI Andes (Eastman, 2006). Na etapa seguinte, o mapa de declividade foi reclassificado (Tabela 9) conforme Bertoni \& Lombardi Neto (1990).

Tabela 9. Valores de LS atribuídos às classes de declividade.

\begin{tabular}{cccc}
\hline Declive (\%) & Fator LS & Declive $(\%)$ & Fator LS \\
\hline 1 & 0,18 & 12 & 3,36 \\
2 & 0,41 & 14 & 4,03 \\
4 & 0,92 & 16 & 4,72 \\
6 & 1,48 & 18 & 5,43 \\
8 & 2,08 & 20 & 6,14 \\
10 & 2,71 & & \\
\hline
\end{tabular}




\subsubsection{Fatores de uso e manejo do solo $(C)$ e práticas conservacionistas $(P)$}

Os fatores C e P são tratados independentemente na RUSLE. Entretanto, neste estudo eles foram correlacionados. De acordo com Stein et al. (1987), estes fatores são fortemente correlacionados, assim, não podem ser analisados individualmente no cálculo de perda de solo por erosão. Assim, a correlação entre os fatores C e P foi calculada (Tabela 10), baseando-se em Paranhos Filho (2003).

Tabela 10. Valores de CP atribuídos às classes de uso do solo.

\begin{tabular}{lclc}
\hline \multicolumn{1}{c}{ Descrição } & Fator CP & \multicolumn{1}{c}{ Descrição } & Fator CP \\
\hline Aeroportos & 0,00000 & Mangues & 0,00000 \\
Campo Antrópico & 0,10000 & Mata & 0,00004 \\
Campos úmidos & 0,00000 & Mata Ciliar & 0,00004 \\
Corpos D'Água & 0,00000 & Mineração & 0,10000 \\
Cultura Anual & 0,20000 & Reflorestamento & 0,00010 \\
Cultura Perene & 0,01000 & Restingas & 0,00000 \\
Culturas Semi-Perenes & 0,01500 & Área Urbana & 0,00000 \\
Industrial & 0,00000 & & \\
\hline
\end{tabular}

\subsection{Criação do mapa de suscetibilidade a deslizamentos}

Mapas litológico, geomorfológico, pedológico e de vegetação foram utilizados para a análise da susceptibilidade a deslizamento. A análise multi-critérios escolhida para a elaboração deste mapa, a Combinação Linear Ponderada (Weighted Linear Combination) foi realizada no software IDRISI Andes (Eastman, 2006). Algumas etapas preliminares, como o ajuste dos fatores, foram desenvolvidas no software ArcMap (ESRI, 2009).

Os mapas parciais utilizadas para elaborar os fatores de entrada à Combinação Linear Ponderada são os seguintes:

\subsubsection{Mapa de declividade}

De acordo com Valdemeri (1997) o fator declividade tem forte influência na distribuição dos diferentes tipos de solo e em processos de erosão. Kulman et al. (2004) relataram que a análise da declividade é de grande importância para identificar as características de uma bacia hidrográfica e suas relações com os tipos de uso do solo. Neste estudo o mapa de declividade foi obtido através de curvas de nível na escala 1:50.000 (com intervalo de 20 metros), produzidas pelo Instituto Geográfico e Cartográfico do Estado de São Paulo (IGC) e incorporadas ao Sistema de Informações Geográficas do Ribeira de Iguape e 
Litoral Sul (SIG-RB). Na primeira etapa foi gerado um Modelo Digital de Elevação (DEM) utilizando o software ArcMap (ESRI, 2009). Em seguida, foi elaborado um mapa de declividades a partir do DEM, no software IDRISI Andes (Eastman, 2006).

\subsubsection{Mapa litológico}

Liu et al. (1992) afirmaram que as condições geológicas desempenham um importante papel no processo de deslizamento de encostas. Os autores correlacionaram os tipos de rocha, frequência e intensidade de terremotos e a densidade de falhas geológicas e concluíram que o tipo de rocha tem grande influência neste tipo de acidente geológico. O mapa litológico utilizado nesta pesquisa está na escala 1:250.000 e foi elaborado por Campanha et al. (2007).

\subsubsection{Mapa pedológico}

De acordo com Sidle et al. (1985) movimentos de massa são diretamente relacionados com características pedológicas e hidrológicas. A estabilidade de uma encosta é relacionada à intensidade de precipitação pluviométrica, taxas de infiltração e pressão do solo. As características químicas e mineralógicas do solo também são fundamentais para o movimento de massa ocorrer ou não, pois influenciam as propriedades da argila. Um mapa vetorial georeferenciado (escala 1:250.000) e um banco de dados foram desenvolvidos com base no "Levantamento de reconhecimento com detalhes dos solos da região do Ribeira de Iguape no Estado de São Paulo” (Lepsch et al., 1999).

\subsubsection{Mapa de uso e ocupação do solo}

O tipo de vegetação é um importante fator na determinação de áreas suscetíveis a movimentos de massa, pois estes tipos de eventos podem ser fortemente induzidos em áreas íngremes e com cobertura vegetal de grande porte, pois um grande volume de chuva combinado com a presença de solo raso pode provocar uma sobrecarga sobre a superfície da rocha. Entretanto, em certas áreas a presença de vegetação pode minimizar a possibilidade de ocorrência de movimentos de massa (Nummer, 2003). Monguilhott (2008) confirma os benefícios dos efeitos da vegetação na estabilidade de encostas, pois a supressão da vegetação aumenta a velocidade de carreamento da água. Os dados utilizados neste fator foram obtidos no SIG-RB, na escala 1:250.000. 


\subsubsection{Geomorfologia}

O estudo da geomorfologia permite a avaliação do grau de inclinação do relevo. Através desta informação é possível quantificar a energia potencial disponível para o escoamento superficial da água das chuvas. Em paisagens naturais, em locais onde a inclinação é elevada os processos morfogenéticos prevalecerão (Crepani et al., 2001). De acordo com Penteado (1983), a morfogênese é um processo natural, porém tem sofrido alterações pela ação antrópica, que podem resultar em alterações na estabilidade dos terrenos. Os dados geomorfológicos foram obtidos a partir do SIG-RB na escala 1:250.000, baseados em Ross (2002).

\subsubsection{Erosividade da chuva}

Mesma descrição do item "9.2.1.1. Erosividade da chuva (R)", dentro do capítulo "9.2. Criação do mapa de vulnerabilidade a processos erosivos".

\subsection{Padronização dos critérios}

Devido às diferenças tanto quantitativas como qualitativas que há entre os critérios utilizados nesta avaliação foi necessário fazer uma padronização para que estes pudessem ser correlacionados. No IDRISI Andes, o módulo fuzzy é responsável pela padronização dos fatores. Este módulo fornece as opções de padronização dos fatores tanto para uma escala de números reais, zero e um, quanto para uma escala em bytes, zero e 255. Está última opção é a recomendada para o IDRISI porque o módulo MCE foi projetado para processamentos mais rápidos com números de um byte (Eastman, 2006).

\subsection{Ponderação dos critérios}

Há diferentes fatores utilizados nas análises multi-critérios para confecção das cartas de vulnerabilidade a deslizamentos, sendo extremamente necessário determinar os pesos das classes que compõem esses fatores.

\subsubsection{Pedologia}

Baseado no estudo de Crepani et al. (2001), às classes de solo da UGRHI-11 foram atribuídos os pesos apresentados na Tabela 11. 
Tabela 11. Classes pedológicas e respectivos pesos.

\begin{tabular}{lclc}
\hline \multicolumn{1}{c}{ Classe pedológica } & Peso & \multicolumn{1}{c}{ Classe pedológica } & Peso \\
\hline Brunizem Avermelhado & 2 & Solo de Mangue & 3 \\
Cambissolo Álico & 2,5 & Solos Aluviais Distróficos & 3 \\
Cambissolo Distrófico & 2,5 & Solos Gleizados Álicos & 3 \\
Cambissolo Eutrófico & 2,5 & Solos Gleizados Distróficos & 3 \\
Latossolo Amarelo Álico & 1 & Solos Gleizados Tiomórficos & 3 \\
Latossolo Variacão Una Distrofico ou Alico & 1 & Solos Litolicos Álicos & 3 \\
Latossolo Vermelho Amarelo Alico & 1 & Solos Litolicos Distróficos & 3 \\
Podzol & 2 & Solos Organicos Álicos & 3 \\
Podzolico Bruno Acizentado Eutrofico & 2 & Solos Orgânicos Álicos Soterrados & 3 \\
Podzolico Vermelho Amarelo Alico & 2 & Solos Orgânicos Tiomórficos & 3 \\
Podzolico Vermelho Amarelo Distrofico & 2 & Terra Bruna Estruturada Distrófica & 2 \\
\hline
\end{tabular}

\subsubsection{Litologia}

Baseando-se no trabalho de Crepani et al. (2010a) que pondera as classes litológicas num intervalo de zero a três (maior vulnerabilidade a movimentos de massa), as litologias subjacentes à UGRHI-11 receberam os seguintes pesos, visualizados na Tabela 12.

Tabela 12. Classes litológicas e respectivos pesos.

\begin{tabular}{lclc}
\hline \multicolumn{1}{c}{ Classe Litológica } & Peso & \multicolumn{1}{c}{ Classe Litológica } & Peso \\
\hline Alcalinas Indiscriminadas & 0,6 & Meta-Básicas, Anfibolitos & 1,8 \\
Aluviões & 3 & Meta-Ritmito, Ardósias e Filitos & 2,1 \\
Carbonatitos & 0,6 & Metabrechas & 2,1 \\
Carbonato Filitos & 2,1 & Metassiltitos & 2,1 \\
Carbonato-Xistos & 2,1 & Micaxistos & 2,4 \\
Filitos & 2,1 & Migmatitos & 1,3 \\
Filitos e Xistos Finos & 2,4 & Migmatitos Estromatoliticos & 1,8 \\
Gabros e Diabásios & 1,6 & Milonitos e Cataclasitos & 1,7 \\
Granito Quartzo Dioritico e Gnaisses & 1,1 & Mármores & 2,3 \\
Granito Quartzo Sienito & 1,1 & Mármores Dolomiticos e Micaxistos & 0,6 \\
Granulitos Gnáissicos & 1,2 & Nefelina Sienitos & 1,4 \\
Hornfels & 1,2 & Ortognaisses & 1,2 \\
Ijolitos & 0,6 & Peridotitos & 0,6 \\
Jacupiranguitos & 0,6 & QF & 2,4 \\
Lamas & 0,6 & Quartizito & 1 \\
Meta-Arenito & 2,1 & Xistos Migmatizados & 2,4 \\
\hline
\end{tabular}




\subsubsection{Uso e ocupação do solo}

Baseado no estudo de Crepani et al. (2001), às classes de uso e ocupação do solo da UGRHI-11 foram atribuídos os pesos apresentados na Tabela 13.

Tabela 13. Classes de uso e ocupação do solo e respectivos pesos.

\begin{tabular}{lc}
\hline \multicolumn{1}{c}{ Tipo de Uso e ocupação } & Peso \\
\hline Agricultura de cultura cíclica & 2.9 \\
Agricultura de cultura permanente & 3.0 \\
Areia & 0.5 \\
Campo antrópico & 2.7 \\
Contato floresta ombrófila densa/floresta ombrófila mista & 1.2 \\
Corpo de água & 0.0 \\
floresta ombrófila densa alto montana & 1.0 \\
floresta ombrófila densa de terras baixas & 1.0 \\
floresta ombrófila densa montana & 1.0 \\
floresta ombrófila densa submontana & 1.0 \\
floresta ombrófila mista montana & 1.3 \\
Formação arbórea/arbustiva-herbácea de terrenos marinhos lodosos & 1.4 \\
Formação arbórea/arbustiva-herbácea de várzea & 1.4 \\
Formação pioneira arbustiva-herbácea sobre sedimentos marinhos recentes & 2.3 \\
Mineração & 3.0 \\
Piscicultura & 0.0 \\
Reflorestamento de Eucalipto & 1.5 \\
Reflorestamento de Pinheiro & 1.5 \\
Solo exposto & 3.0 \\
Área urbana & 3.0 \\
Vegetação secundária da floresta ombrófila densa de terras baixas & 1.5 \\
Vegetação secundária da floresta ombrófila densa montana & 1.5 \\
Vegetação secundária da floresta ombrófila densa submontana & 1.5 \\
Vegetação secundária da floresta ombrófila densa alto montana & 1.5 \\
Vegetação secundária da floresta ombrófila mista alto montana & 1.8 \\
Vegetação secundária da floresta ombrófila mista montana & 1.8 \\
Vegetação secundária da formação arbórea/arbustiva-herbácea de várzea & 1.9 \\
Vegetação secundária da formação arbórea/arbustiva-herbácea de terrenos marinhos lodosos & 1.9 \\
Vegetação secundária da formação pioneira arbustiva-herbácea sobre sedimentos marinhos recentes & 2.8 \\
Vegetação secundária do contato floresta ombrófila densa/floresta ombrófila mista & 1.7 \\
\hline & \\
&
\end{tabular}




\subsubsection{Geomorfologia}

De acordo com Crepani et al. (2001) o grau de dissecação do relevo é associado à porosidade e permeabilidade das rochas. Rochas e solos impermeáveis dificultam a infiltração da água da chuva e, consequentemente, a drenagem superficial é mais intensa. Um maior volume de água carreado na superfície representa maior disponibilidade de energia potencial para o escoamento e uma maior capacidade de promover morfogênese. Quanto menor o grau de dissecação tanto menor a possibilidade de ocorrer um escorregamento. De acordo com estes dados, as classes geomorfológicas foram ponderadas de acordo com a declividade e a densidade das linhas de drenagem. Assim, quanto maior a inclinação e mais densa a rede de drenagem, maior será a vulnerabilidade a escorregamento. As classes de geomorfologia da área da UGRHI-11 receberam os pesos apresentados na Tabela 14.

Tabela 14. Geomorfologia e respectivos pesos.

\begin{tabular}{lc}
\hline \multicolumn{1}{c}{ Unidade Geomorfológica } & PESO \\
\hline Planalto e Serra de Paranapiacaba & 4 \\
Depressão tectônica do baixo Ribeia & 1 \\
Planalto de Guapiara & 2 \\
Planalto do alto Ribeira do Turvo & 2 \\
Planalto e serra de Paranapiacaba & 4 \\
Planicie costeira Iguape-Cananeia & 1 \\
Planicies e terraços fluviais do baixo Ribeira & 1 \\
Serra do mar e morros litorâneos & 4 \\
\hline
\end{tabular}

\subsubsection{Erosividade das chuvas}

Este fator foi normalizado. Os valores variam entre 757,28 e 912,05 MJ/ha-mm. Deste modo, este intervalo foi convertido, com os valores convertidos a índices variando entre zero e 255 .

Usando o módulo weight do software IDRISI Andes (Eastman, 2006), os critérios foram colocados em uma matriz para realizar todas as possíveis comparações, de maneira que todos os fatores foram comparados uns aos outros, o que resultou na determinação dos seguintes pesos:

- Pedologia: 0.0714

- Geomorfologia: 0.1429

- Erosividade da chuva: 0.2143
- Geologia: 0.1429

- Declividade: 0.2143

- Uso e ocupação do solo: 0.2143 


\subsection{Validação das cartas}

O Comitê da Bacia Hidrográfica do Ribeira do Iguape e Litoral Sul do Estado de São Paulo (CBR-RB) desenvolveu o projeto "Levantamento e monitoramento de áreas de risco na UGRHI-11 e apoio à Defesa Civil”, financiado pelo Fundo Estadual de Recursos Hídricos do Estado de São Paulo (FEHIDRO). Parte da metodologia deste projeto incluiu campanhas de inspeção de campo para quantificar as áreas suscetíveis a algum risco (movimentos de massa, erosão e/ou inundação) nos vinte e três municípios localizados na UGRHI-11.

Inicialmente, foram realizadas reuniões com representantes dos municípios para identificar áreas de alto risco, utilizando fotografias aéreas e produzir arquivos vetoriais (shapefiles). Com base nas informações sobre estas áreas de risco e inspeções de campo, que incluíram o registro da localização das áreas através de coordenadas geográficas (utilizando receptores GPS), iniciou-se a elaboração dos relatórios com registros fotográficos. Foram identificadas 230 áreas, com 339 setores de risco (inundações, erosão e movimento de massa). Deste total, 132 áreas com evidência de escorregamentos foram inspecionadas, sendo 128 localizadas dentro dos limites da UGRHI-11.

A fim de verificar a precisão dos mapas de suscetibilidade à erosão, foram utilizados os dados obtidos durante as campanhas de campo do projeto de Levantamento e Monitoramento de Áreas de Risco na UGRHI-11 e Apoio à Defesa Civil.

A ferramenta "Extraction by Mask" do software ArcMap (ESRI, 2009) foi utilizada para, com o arquivo vetorial (shapefile) referente às áreas com movimentos de massa indicadas pelas Prefeituras, recortar o mapa de suscetibilidade a movimentos de massa. Assim, foi possível obter a porcentagem de pixels classificados como de muito baixa, baixa, moderada, alta e muito alta suscetibilidade a escorregamentos e comparar este resultado com os dados adquiridos em campo.

\subsection{Resultados}

Além da elaboração dos mapas de suscetibilidade a erosão e movimento de massa, um Sistema de Informações Geográficas (SIG) específico para a avaliação de riscos naturais foi criado para UGRHI-11 e inserido no SIG geral da bacia (SIG-Ribeira). A principal vantagem deste sistema é a possibilidade de poder inserir no banco de dados novos mapas de, por exemplo, solos e vegetação, desta forma é possível atualizar periodicamente a base de dados. Outros mapas temáticos, como os tipos de uso e ocupação do solo podem ser sobrepostos às áreas de risco, o que demonstra a versatilidade do modelo obtido. 
Todos os arquivos descritos estão disponíveis para download no site do Sistema de Informações Geográficas da Bacia do Ribeira de Iguape e Litoral Sul (www.sigrb.com.br). Os mapas de suscetibilidade estão descritos a seguir:

\subsubsection{Mapa de suscetibilidade a erosão}

Este mapa foi processado utilizou-se a Equação Universal de Perda de Solo Revisada (Revised Universal Soil Loss Equation - RUSLE). As áreas de maior suscetibilidade a erosão estão localizadas nos municípios de Apiaí, Barra do Chapéu, Barra do Turvo, Cajati, Eldorado, Itaóca, Itapirapuã Paulista e Ribeira. Na UGRHI-11 a perda do solo está entre zero e 56 toneladas de solo por hectare ao ano (Figura 11). 
9.7.2. Mapa de suscetibilidade a movimentos de massa

O mapa resultante das análises desenvolvidas em ambiente SIG apresenta apenas $2.36 \%$ da área total da UGRHI-11 classificada como muito baixa suscetibilidade a movimentos de massa; $21,97 \%$ em baixa suscetibilidade; 47,08\% em moderada suscetibilidade; $26,47 \%$ de alta suscetibilidade; e 2,12\% da área total está contida em áreas de muito alta suscetibilidade (Tabela 15). Ou seja, 28,6\% $\left(4.879,71 \mathrm{~km}^{2}\right)$ da área total da UGRHI-11 está inserida em áreas de alta e muito alta suscetibilidade a movimentos de massa, de modo que as chuvas intensas que ocorrem durante o verão no Vale do Ribeira podem desencadear situações de risco (Figura 12).

Tabela 15. Áreas suscetíveis a movimentos de massa na UGRHI-11.

\begin{tabular}{lcc}
\hline \multicolumn{1}{c}{ CLASSES } & Área $(\mathrm{km} 2)$ & Área $(\%)$ \\
\hline Muito baixa & 394,41 & 2,36 \\
Baixa & 3673,66 & 21,97 \\
Moderada & 7872,53 & 47,08 \\
Alta & 4427,35 & 26,47 \\
Muito alta & 355,24 & 2,12 \\
\hline
\end{tabular}

Apenas dez das 128 áreas inspecionadas (8\%) estão localizadas em áreas classificadas como de baixa suscetibilidade a movimentos de massa; 56 áreas (44\%) em locais de moderada suscetibilidade; 55 áreas (43\%) como alta suscetibilidade; e 7 áreas (5\%) em locais de muito alta suscetibilidade (Tabela 16). Portanto, das 128 áreas inspecionadas, 62 casos de movimento de massa (48\%) ocorreram em áreas classificadas como de alta e muito alta suscetibilidade a este tipo de evento.

Tabela 16. Suscetibilidade a movimentos de massa nas áreas inspecionadas.

\begin{tabular}{ccc}
\hline CLASSES & Total & $(\%)$ \\
\hline Baixa & 10 & 7,81 \\
Moderada & 56 & 43,75 \\
Alta & 55 & 42,97 \\
Muito alta & 7 & 5,47 \\
\hline
\end{tabular}




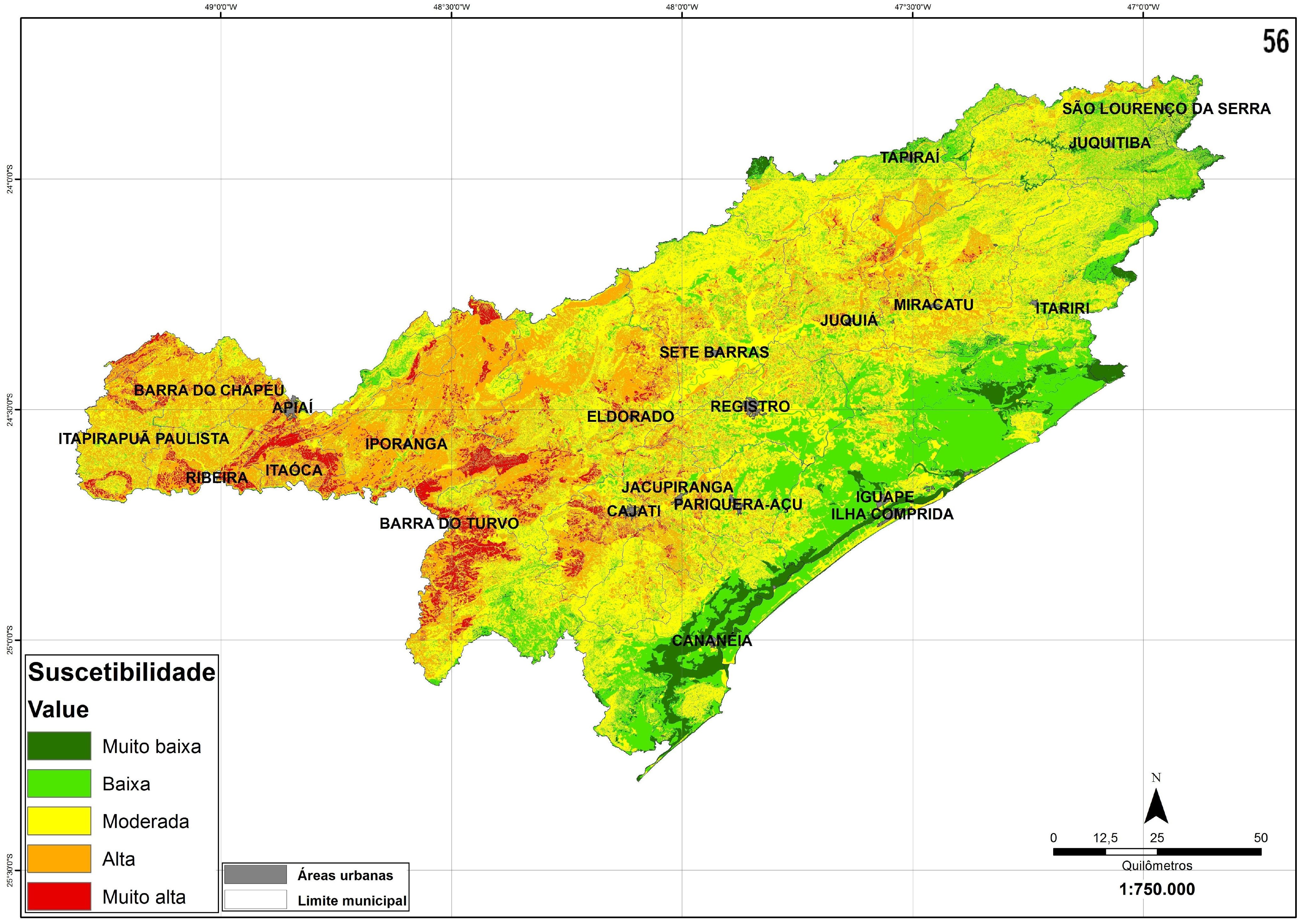


Na cidade de Barra do Turvo, sete áreas com problemas de movimentos de massa foram inspecionadas. No ponto BAR-5-3 (longitude: 48²7'54.46"O, latitude: 2455'28.90"S) a vegetação está presente, porém é de pequeno porte. É possível que o evento tenha ocorrido principalmente pela declividade, a qual é bastante alta. Esta área é classificada como de alta suscetibilidade no mapa de suscetibilidade a movimentos de massa (Figura 13).

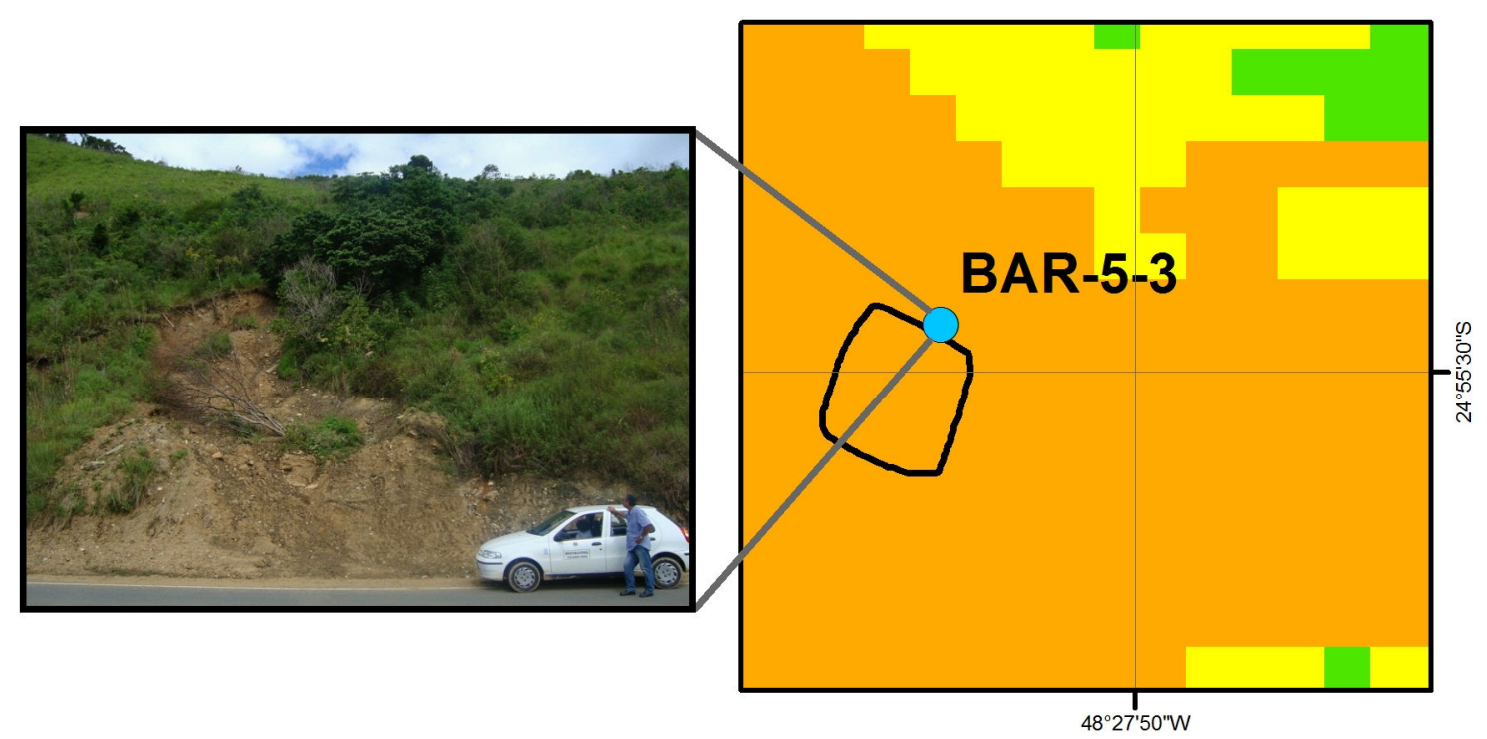

Coordenada coletada em campo - Barra do Turvo

Áreas com processos de movimento de massa (local indicado pela Prefeitura de Barra do Turvo) Movimento de massa - Suscetibilidade Value

Muito baixa

$\square$ Baixa

$\square$ Moderada

$\square$ Alta

Muito alta

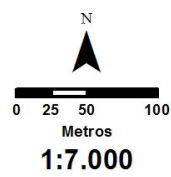

Figura 13. Área com movimento de massa na cidade de Barra do Turvo (setor BAR-5-3).

Em Cajati, onde foram vistoriadas dezesseis áreas, o perfil de rocha alterada é bastante espesso no setor CAJ-6-1 (longitude: $48^{\circ} 6^{\prime} 32.81^{\prime \prime O}$, latitude: $24^{\circ} 43^{\prime} 55.26^{\prime \prime S}$ ), fato que aliado a grandes chuvas e a pouca cobertura vegetal resultou num processo de escorregamento. Como pode ser observado na Figura 14, este escorregamento ocorreu em uma área de alta suscetibilidade. 


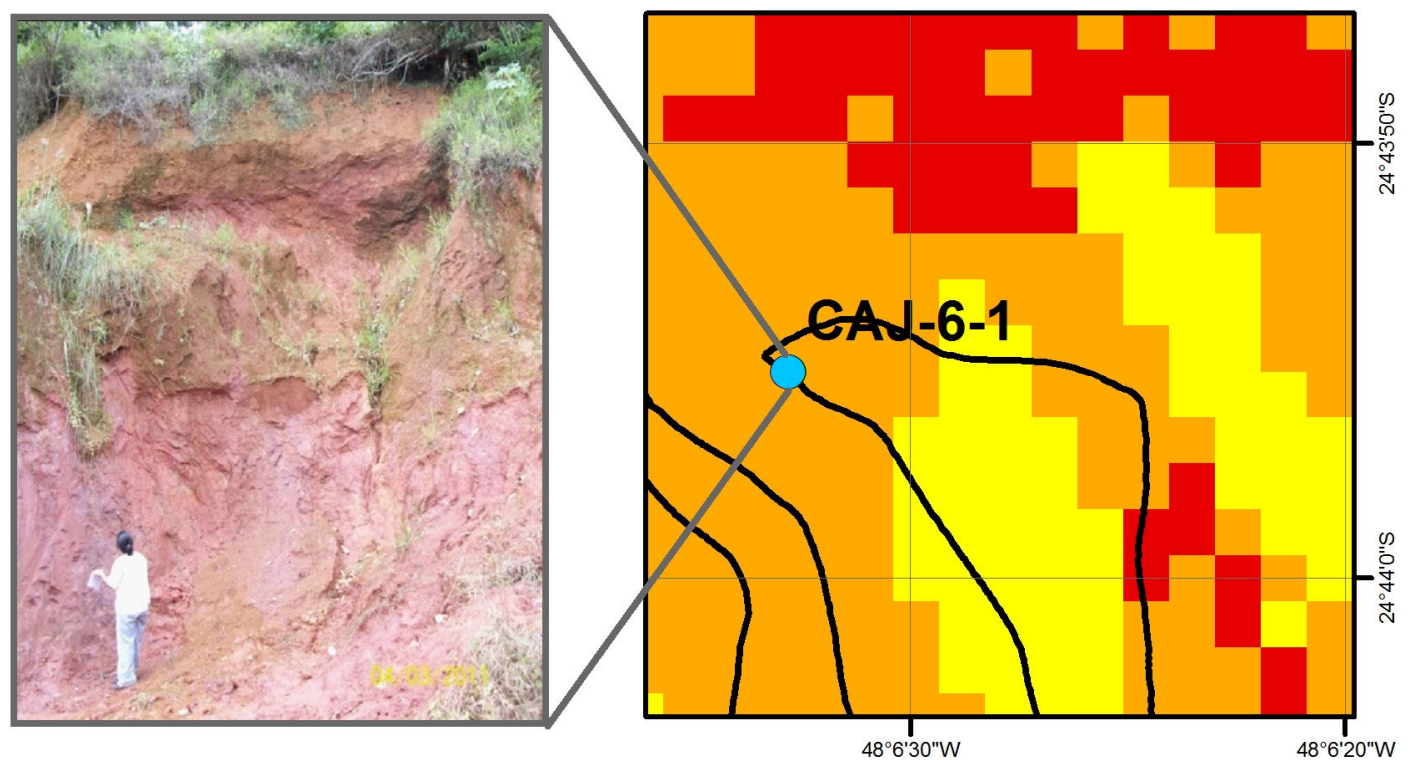

\section{Coordenada coletada em campo - Cajat}

Área com processo de movimento de massa (local indicado pela Prefeitura de Cajati) Movimento de massa - Suscetibilidade

Value
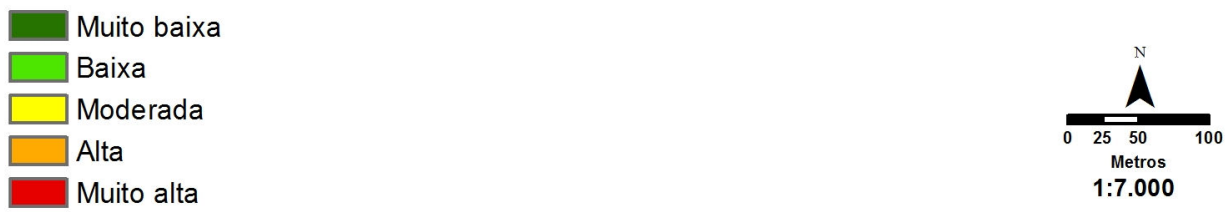

Figura 14. Área com movimento de massa na cidade de Cajati (setor CAJ-6-1).

No Município de Eldorado, onde ocorreram movimentos de massa em nove áreas, localizadas no setor ELD-8-2 (longitude: 48¹6'34.79"O, latitude: 24³5'50.89"S), a situação é de vegetação escassa e alta declividade. Este setor está localizado numa área de muito alta suscetibilidade a movimentos de massa (Figura 15). 


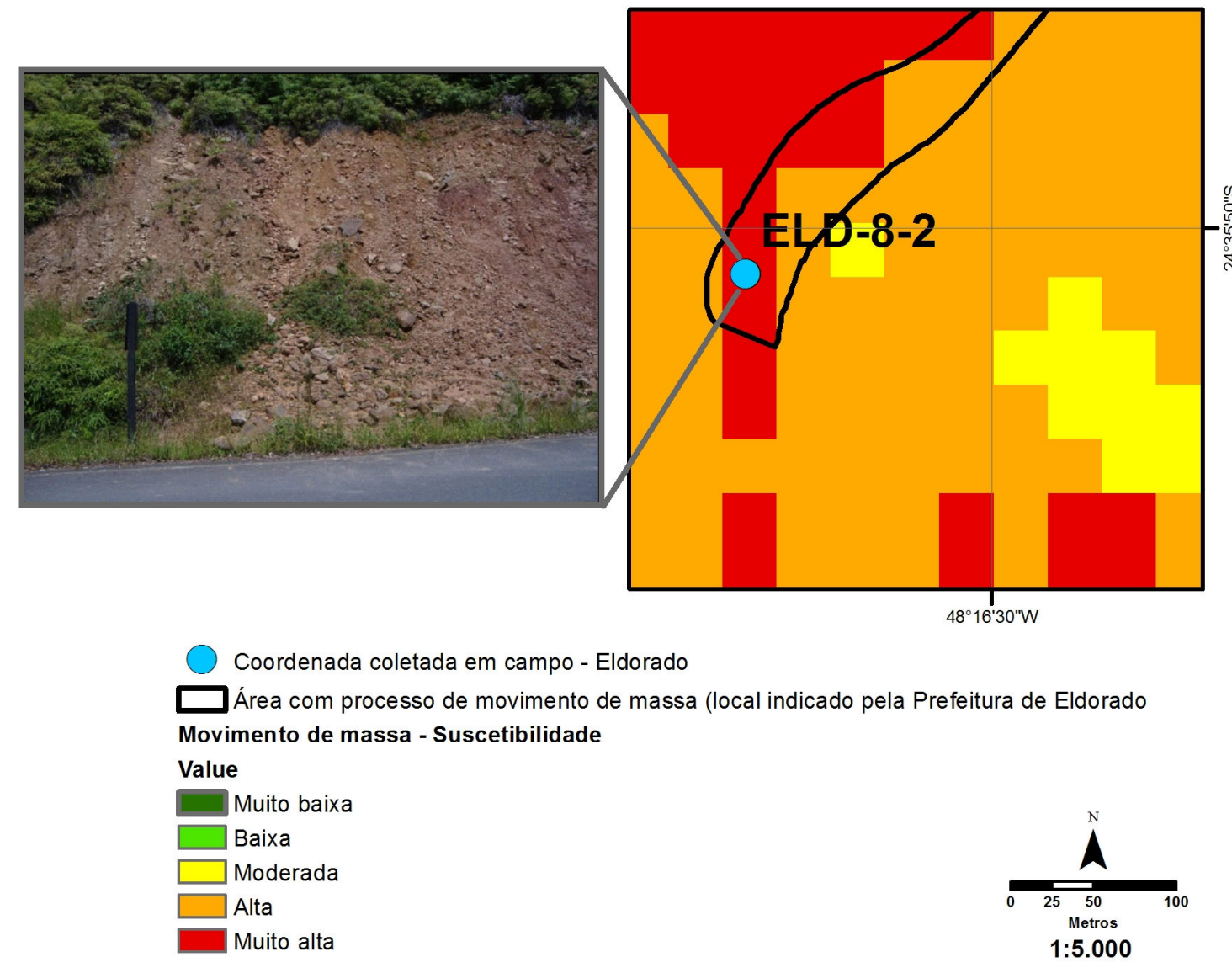

Figura 15. Área com movimento de massa na cidade de Eldorado (setor ELD-8-2).

\subsection{Discussões}

A erosão está relacionada às características físicas, tais como o volume e distribuição das chuvas, declividade e geomorfologia, o tipo de vegetação e ação antrópica (Mendonça \& Guerra, 2004). Movimento de massa é um processo diferente, onde há deslocamento de um grande volume de material (solo e rocha) por influência, principalmente, da gravidade (Bigarella, 2003). Assim, ambos os eventos não têm necessariamente de ocorrer no mesmo local ou ao mesmo tempo.

O mapa de suscetibilidade à erosão foi elaborado de acordo com a Equação Universal de Perda de Solo Revisada. Considerando-se os resultados favoráveis obtidos através do confronto com dados de campo, conclui-se que esta técnica foi bem aplicada em relação ao objetivo proposto. Embora o mapa final contenha dados quantitativos, o modelo aqui proposto é mais bem utilizado como um indicador qualitativo às áreas suscetíveis a processos que, com interferência humana, podem resultar em erosão. 
Os dados de campo demonstram e quantificam a eficiência do mapa de suscetibilidade a movimentos de massa. Verificou-se que em 48\% dos 128 locais fiscalizados, houve eventos de deslizamentos em áreas classificadas como de alta e muito alta vulnerabilidade no mapeamento. Os restantes $52 \%$ foram classificados como de "baixa" e "moderada" suscetibilidade. No entanto, estes números não diminuem a importância e a precisão do mapa produzido porque alguns eventos foram causados pela ação antrópica, como o corte de taludes para a construção de casas. É importante notificar que nenhum dos locais inspecionados, com evento de deslizamento, estava inserido em alguma área classificada como de muito baixa vulnerabilidade. Esse fato corrobora com a precisão do mapa de suscetibilidade a movimento de massa.

As Figuras 13, 14 e 15 demonstram que as áreas indicadas como de alta suscetibilidade a movimentos de massa estão localizadas nos municípios de Barra do Turvo e Cajati. Em Eldorado, há áreas de muito alta suscetibilidade. Todos estes três municípios foram inspecionados nas campanhas de trabalho de campo. No mapa de suscetibilidade a movimentos de massa é possível visualizar que outro município com várias áreas críticas é Barra do Chapéu, provavelmente pelo alto grau de declive do terreno. 


\section{EVOLUÇÃO DO USO E OCUPAÇÃO DO SOLO NA UGRHI-11 ENTRE 1986, 1999 E 2010}

\subsection{MATERIAIS E MÉTODOS}

Através da técnica de Classificação Não Supervisionada foram gerados os mapas de uso e ocupação do solo da UGRHI-11 dos anos de 1986, 1999 e 2010. Utilizaram-se as cenas da série Land Remote Sensing Satellite (Landsat 5-TM) das órbitas 219 e 220, ambas referentes à rota 077, que através da criação de mosaico cobriram toda a UGRHI-11.

A seguir a listagem das cenas coletadas na internet, na página do Instituto Nacional de Pesquisas Espaciais (INPE) - www.inpe.br.

- L5TM21907719870926

- L5TM22007719860725

- L5TM21907719990903

- L5TM21907720100824

- L5TM22007720101119

Para georreferenciamento das cenas disponibilizadas pelo INPE, que são ajustadas e não georreferenciadas, utilizou-se cenas do mesmo sensor Landsat 5, porém georreferenciadas e ortorretificadas, que foram retiradas da página eletrônica do Global Land Cover Facility www.landcover.org. As cenas utilizadas para o georrefernciamentos foram:

- p220r77_5t19990926 - Além de ser utilizada para georreferenciamento também participou do processo de classificação.

- p219r77_5t19930622

Primeiramente, as cenas retiradas da página eletrônica do INPE passaram por um préprocessamento, no programa ArcGIS 10 (ESRI, 2010), onde foram georreferenciadas, através da utilização de pontos de controle retirados de uma imagem já ortorrefiticada, no caso as cenas p220r77_5t19990926 e p219r77_5t19930622. A próxima etapa foi correção radiométrica para eliminar "ruídos", através do módulo de correção atmosférica QUAC. Este processo foi realizado no programa ENVI versão 4.7 (ENVI, 2010).

Após o pré-processamento das cenas, foram realizadas as composições de bandas, com o objetivo de criar composições coloridas reais no formato R:G:B = 3:2:1 $(0,63-0,69 \mu \mathrm{m}$ : 0,52 - 0,60 $\mu \mathrm{m}: 0,45-0,52 \mu \mathrm{m})$. De posse das composições, foram processadas as 
classificações não supervisionadas. Dessa forma, foram classificadas as imagens referentes aos anos de 1986/1987, 1999 e 2010. Este processo de classificação não supervisionada foi realizado no ENVI (versão 4.7).

Todos as cenas foram processadas com o objetivo pré-definido de obterem-se 6 classes de uso e ocupação do solo, seguindo a metodologia e descrição de Amaral (2010):

I. Área urbana: A área de estudo é composta por vinte e três áreas urbanas

II. Corpos de água: rios, lagos e reservatórios.

III. Banana: atividade agrícola extensiva de grande importância econômica, social e ambiental na área de estudo.

IV. Vegetação arbórea densa: formações florestais primárias e secundárias, em estágio avançado de regeneração, das fisionomias Floresta Ombrófila Densa Montana, Floresta Ombrófila Densa Submontana e floresta Ombrófila Densa das Terras Baixas.

V. Vegetação de várzea/capoeira/campo antrópico sujo: refere-se às Formações Secundárias das Fisionomias Florestais Atlânticas, com presença de vegetação herbácia, forte expressão de espécies lenhosas de porte arbustivo-arbóres e em menos quantidade espécies arbóreas. Campo antrópico sujo refere-se à fisionomia composta por vegetação herbácea densa, associada a espécies semilenhosas e espécies lenhosas de porte arbustivo-arbóreo.

VI. Solo exposto: áreas sem expressão vegetal.

\subsection{RESULTADOS}

\subsubsection{Uso e ocupação do solo no ano de 1986}

O uso do solo de 1986 da UGRHI-11 (Figura 16) foi extraído por classificação não supervisionada, onde foram utilizadas 30 classes de treinamento, nas bandas 1, 2, 3, 5 e 7 das cenas do sensor Landsat TM de 25/07/1986 (fuso 220) e de 26/09/1987 (fuso 219). Segundo a classificação realizada: $0,25 \%\left(42 \mathrm{~km}^{2}\right)$ da área total estavam ocupadas por áreas urbanas; 0,36\% $\left(61 \mathrm{~km}^{2}\right)$ por bananicultura; 1,71\% $\left(291 \mathrm{~km}^{2}\right)$ por solo exposto; $1,91 \%\left(322 \mathrm{~km}^{2}\right) \mathrm{de}$ corpo de água; $14,06 \%\left(2.390 \mathrm{~km}^{2}\right)$ por vegetação de várzea/capoeira/campo sujo; $81,71 \%$ (13.889 $\mathrm{km}^{2}$ ) vegetação arbórea densa (Figura 17). 


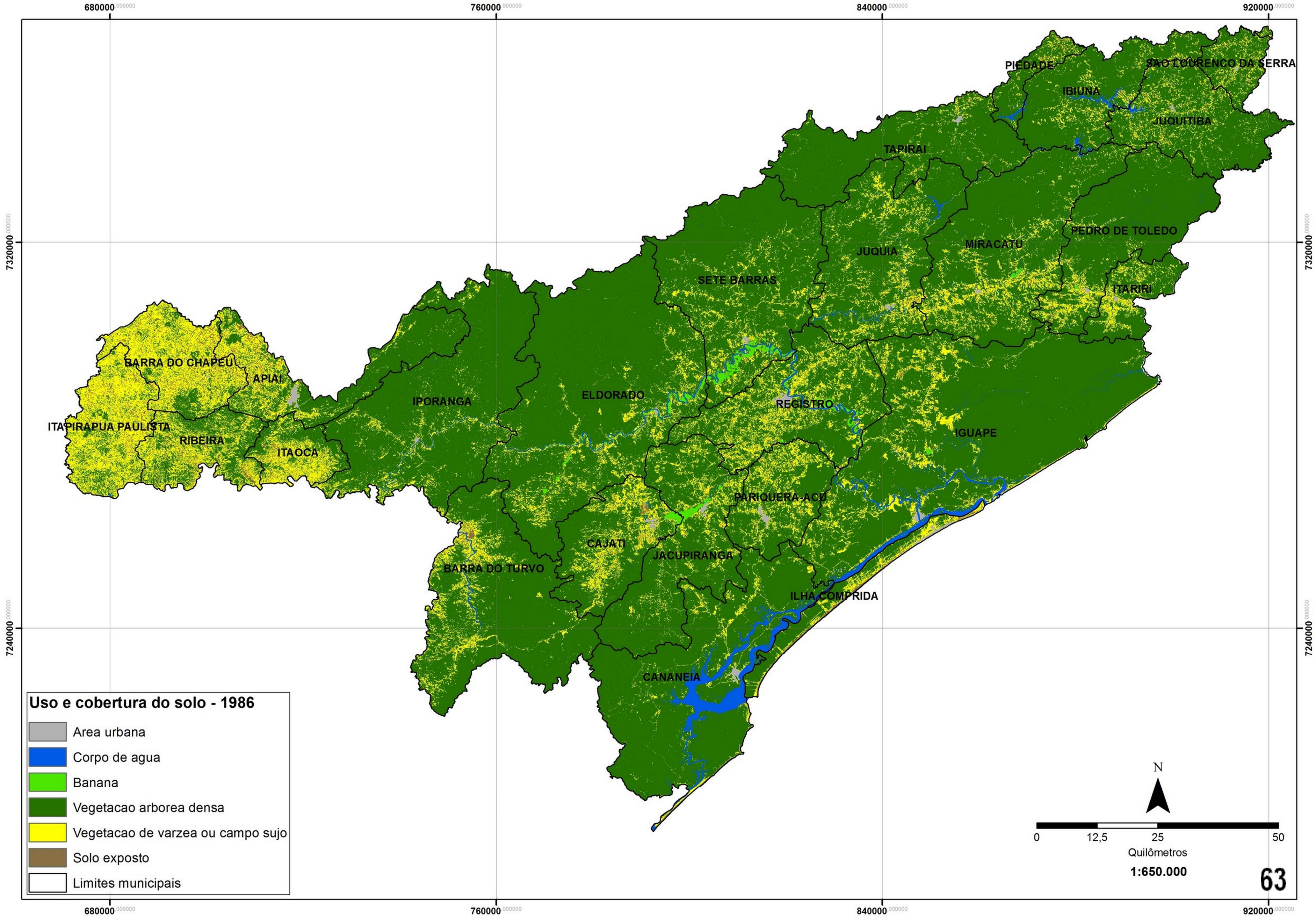




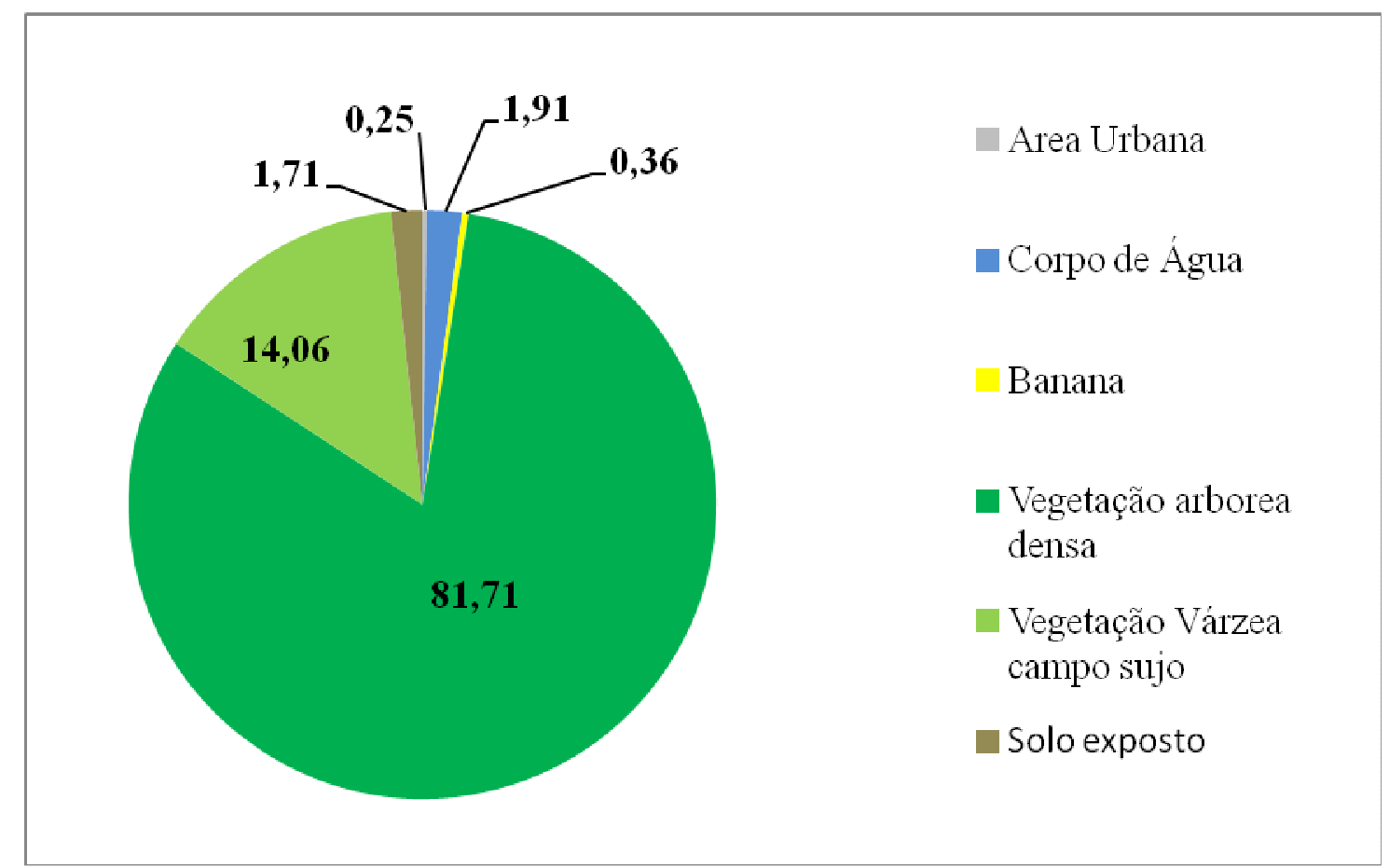

Figura 17. Uso e ocupação do solo da UGRHI-11, em 1986 (em percentagem).

\subsubsection{Uso e ocupação do solo no ano de 1999}

O uso do solo de 1999 (Figura 18) foi extraído por classificação não supervisionada das cenas Landsat TM de 26/09/1999 (fuso 220) e 03/09/1999 (fuso 219). Segundo a classificação realizada: $0,37 \%\left(63 \mathrm{~km}^{2}\right)$ da área total estava ocupada por áreas urbanas; $1,13 \%$ $\left(192 \mathrm{~km}^{2}\right)$ por bananicultura; $1,66 \%$ por corpos de água $\left(282 \mathrm{~km}^{2}\right) ; 4,67 \%\left(795 \mathrm{~km}^{2}\right)$ por solo exposto; 13,44\% $\left(2.227 \mathrm{~km}^{2}\right)$ por vegetação de várzea/capoeira/campo sujo; 78,73\% (13.392 $\mathrm{km}^{2}$ ) vegetação arbórea densa (Figura 19). 


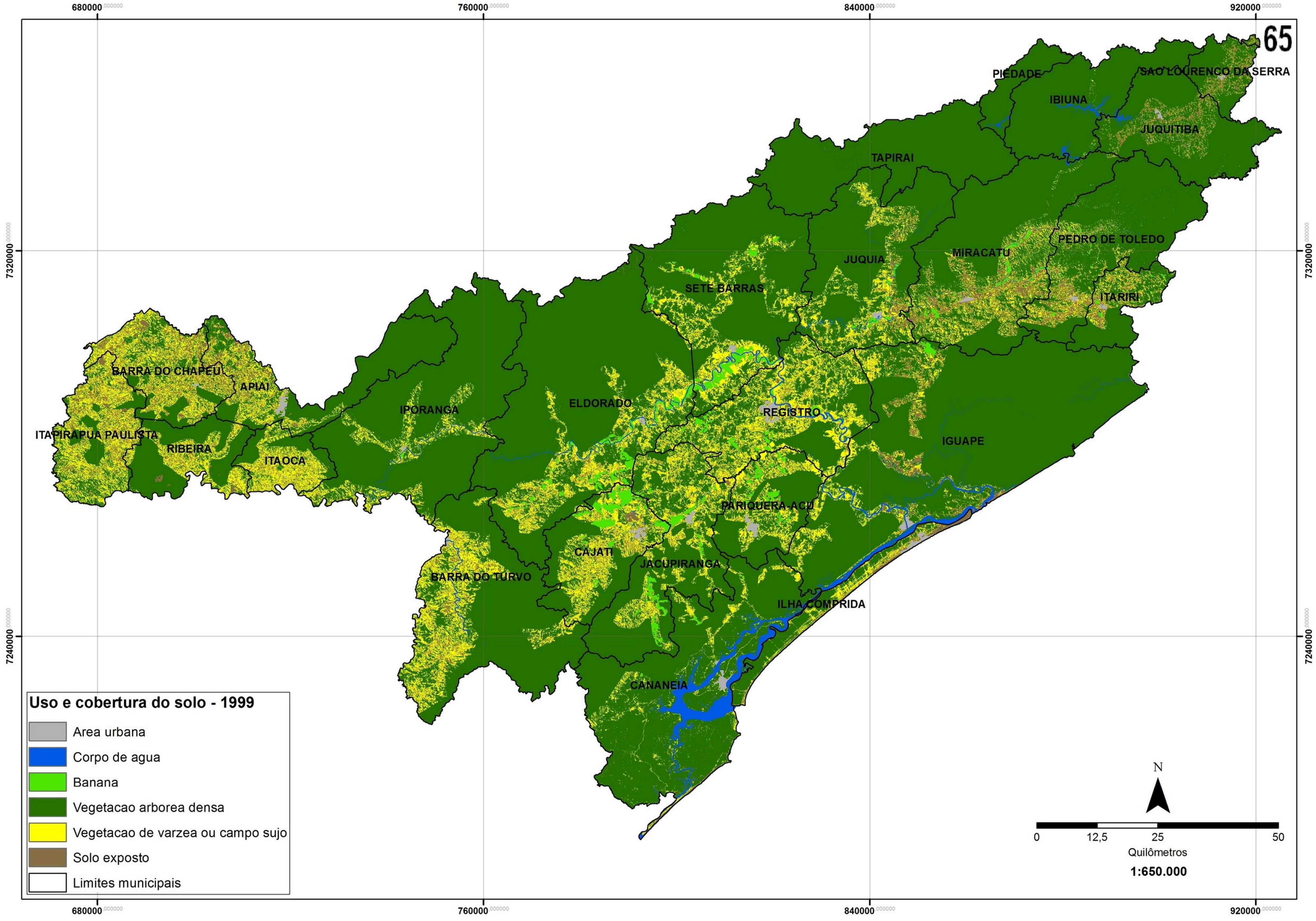




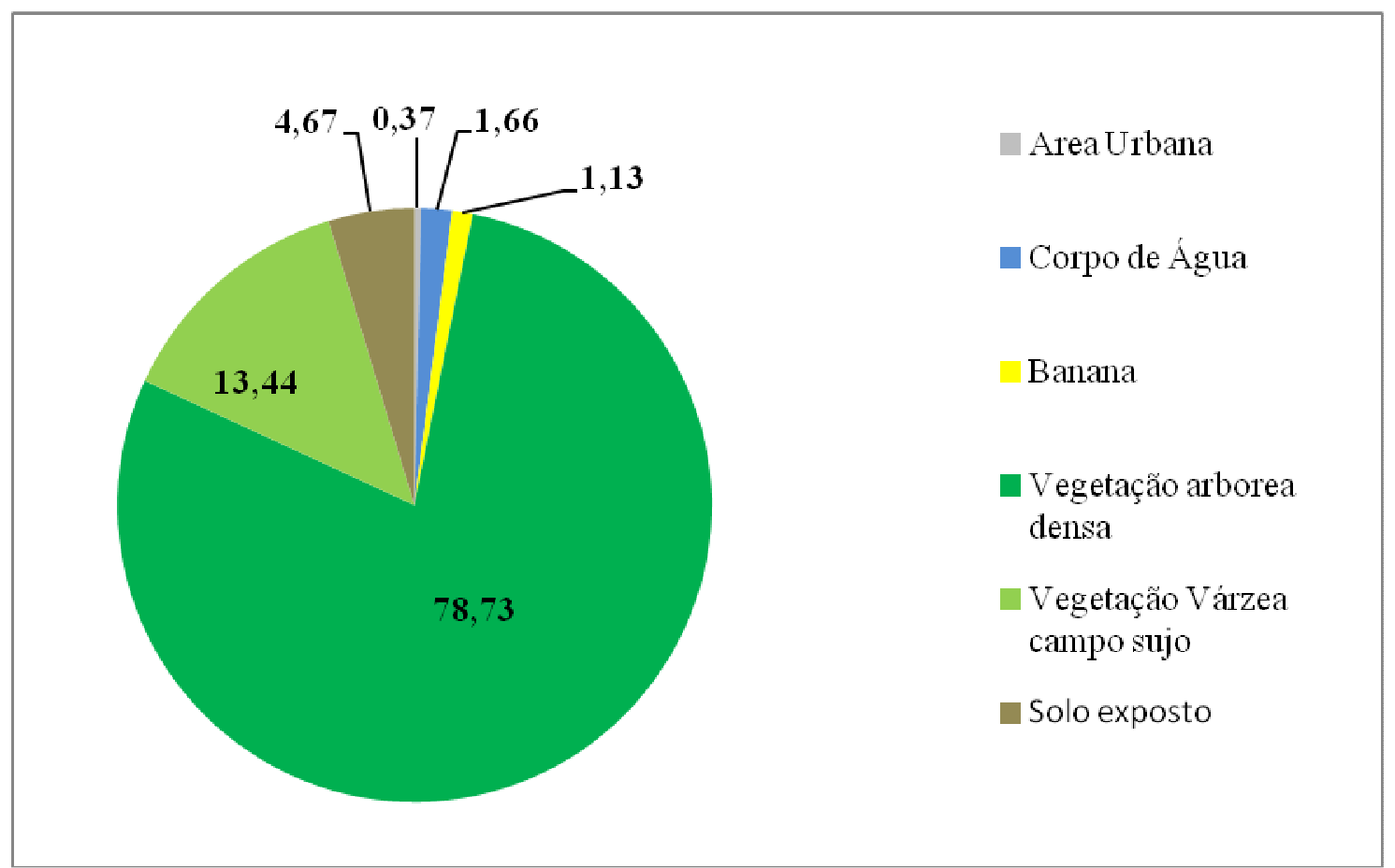

Figura 19. Uso e ocupação do solo da UGRHI-11, em 1999 (em percentagem).

\subsubsection{Uso e ocupação do solo no ano de 2010}

O uso do solo de 2010 (Figura 20) foi extraído por classificação não supervisionada das cenas Landsat TM de 19/01/2010 (fuso 220) e 24/08/2010 (fuso 219). Segundo a classificação realizada: $0,45 \%\left(77 \mathrm{~km}^{2}\right)$ da área total estava ocupada por áreas urbanas; $1,92 \%$ $\left(327 \mathrm{~km}^{2}\right)$ por bananicultura; 3,94\% $\left(670 \mathrm{~km}^{2}\right)$ por solo exposto; 2,07\% $\left(352 \mathrm{~km}^{2}\right) \mathrm{de}$ hidrografia; 9,05\% (1.539 $\left.\mathrm{km}^{2}\right)$ por vegetação de várzea/capoeira/campo sujo; $82,55 \%$ $\left(14.047 \mathrm{~km}^{2}\right)$ vegetação arbórea densa (Figura 21). 


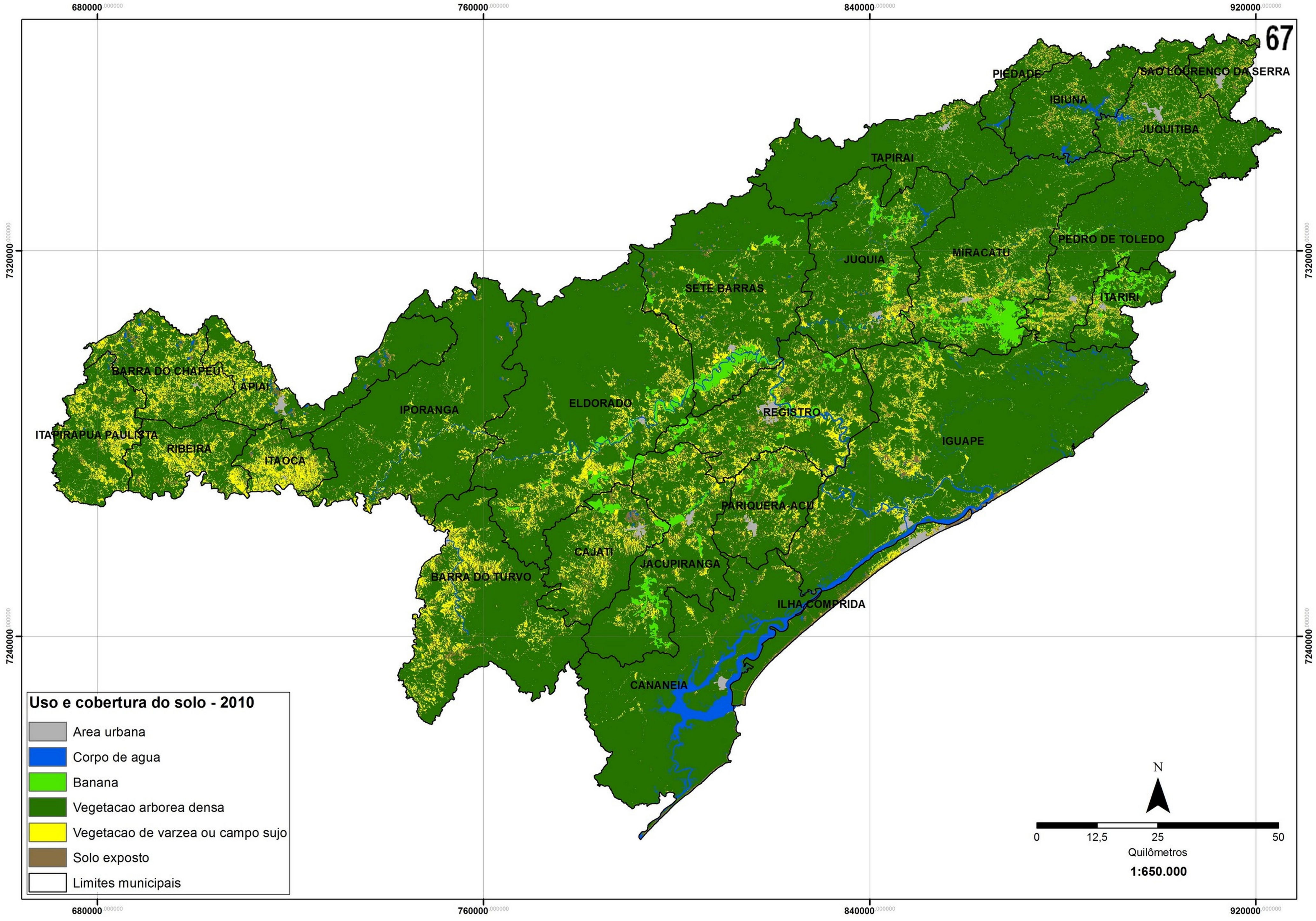




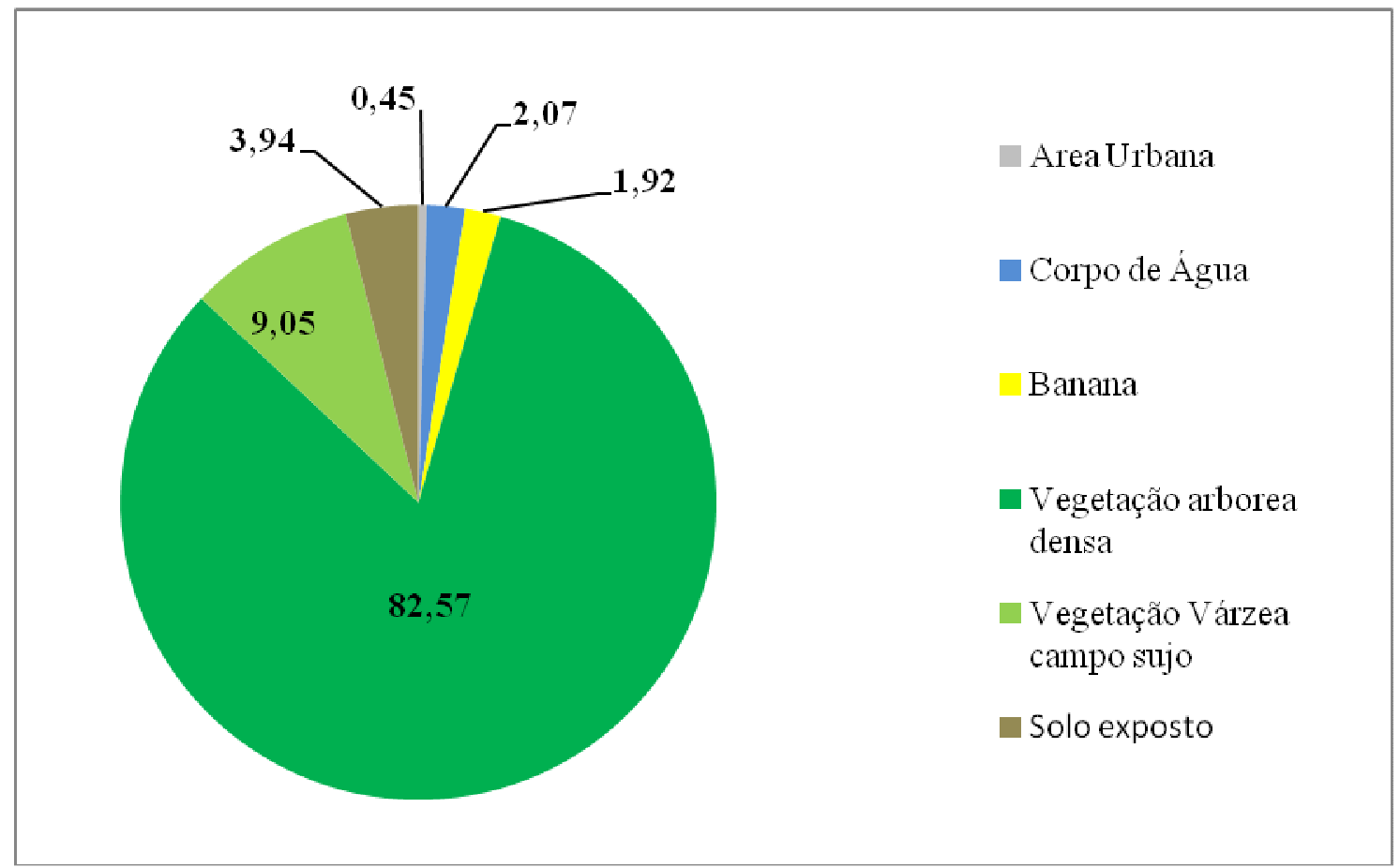

Figura 21. Uso e ocupação do solo da UGRHI-11, em 2010 (em percentagem).

\subsubsection{Uso e ocupação do solo entre os anos do estudo}

A classe com maior representatividade durante os três anos do estudo foi a "vegetação arbórea densa", seguida por "pastagem/campo limpo" e "vegetação de várzea/capoeira/campo sujo", conforme descrito na Tabela 17.

Tabela 17. Uso do solo nos anos estudados, em área $\left(\mathrm{km}^{2}\right)$ e porcentagem.

\begin{tabular}{lccccccc}
\hline \multicolumn{1}{c}{ CLASSES DE USO E OCUPAÇÃO DO } & \multicolumn{2}{c}{1986} & \multicolumn{2}{c}{1999} & \multicolumn{2}{c}{2010} \\
& SOLO & ÁREA $\left(\mathrm{Km}^{2}\right)$ & $\%$ & ÁREA $\left(\mathrm{Km}^{2}\right)$ & $\%$ & ÁREA $\left(\mathrm{Km}^{2}\right)$ & $\%$ \\
\hline Area Urbana & 42 & 0,25 & 63 & 0,37 & 77 & 0,45 \\
Corpo de Água & 322 & 1,89 & 282 & 1,66 & 352 & 2,07 \\
Banana & 61 & 0,36 & 192 & 1,13 & 327 & 1,92 \\
Vegetação arbórea densa & 13.889 & 81,72 & 13.392 & 78,73 & 14.047 & 82,57 \\
Vegetação Várz campo sujo & 2.390 & 14,06 & 2.287 & 13,44 & 1.539 & 9,05 \\
Solo exposto & 291 & 1,71 & 795 & 4,67 & 670 & 3,94 \\
\hline
\end{tabular}




\subsection{Discussões}

Durante o período analisado (1986 - 2010), pode-se constatar que as classes "área urbana" e "bananicultura" apresentam um comportamento linear, enquanto as classes "vegetação arbórea densa", "vegetação de várzea ou campo sujo" e "solo exposto" apresentam comportamentos distintos.

A Figura 22 apresenta a evolução da classe "área urbana" durante o período 1986 a 2010. O crescimento total foi de $83 \%$. Porém, $50 \%$ são referentes apenas ao primeiro período 1986 a 1999.

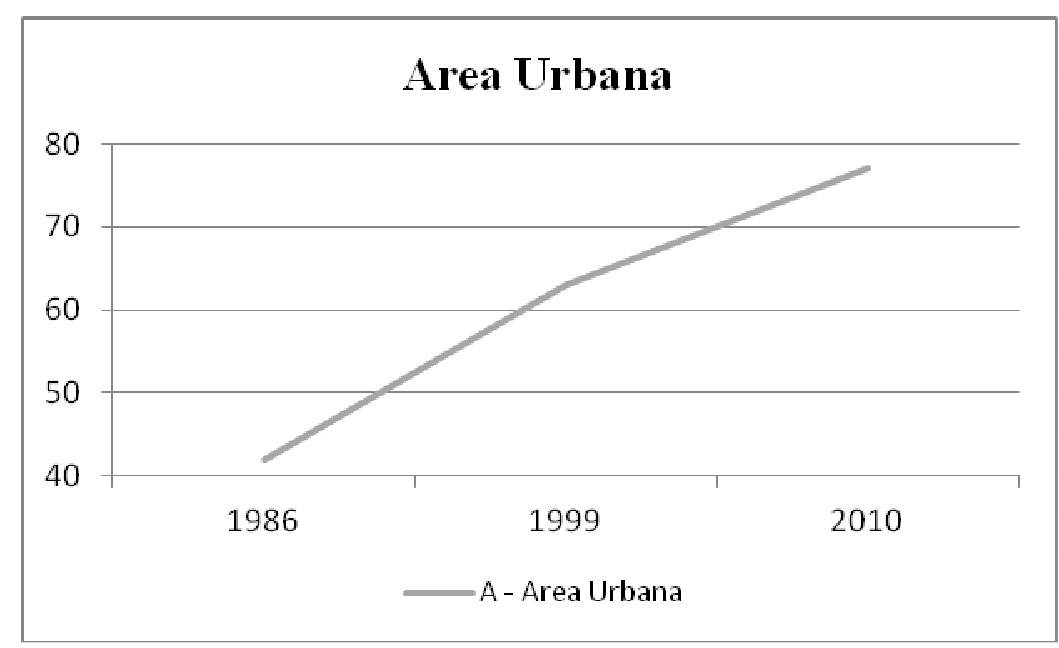

Figura 22. Evolução da classe "área urbana” $\left(\mathrm{em} \mathrm{km}^{2}\right)$.

A área coberta pelos corpos d'água da UGRHI-11 apresenta crescimento dividido em duas situações opostas. No primeiro período (1986-1999) houve um decréscimo de área de 12,5\%. Já no período final, há um crescimento de 25\% da área (Figura 23).

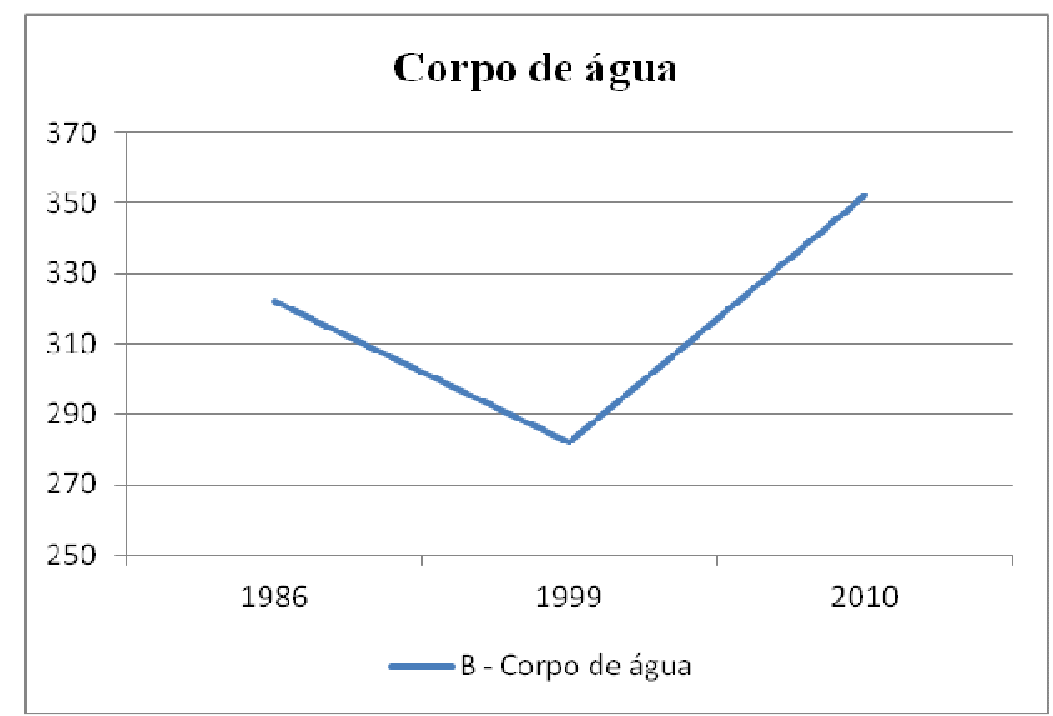

Figura 23. Evolução da classe "corpo de água” ( $\left(\mathrm{em} \mathrm{km}^{2}\right)$. 
A classe "bananicultura" teve um crescimento de $436 \%$ no período total, sendo $214 \%$ durante o primeiro período (1986 a 1999) e os restantes $222 \%$ no segundo período (1999 a 2010) o que demonstra um crescimento, praticamente linear (Figura 24).

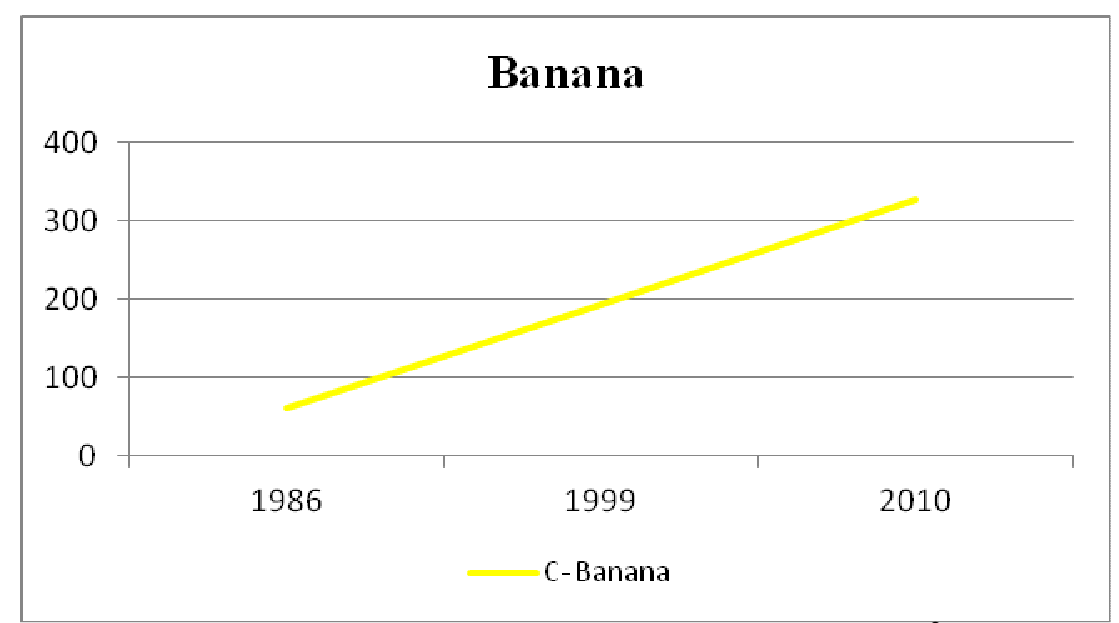

Figura 24. Evolução da classe "bananicultura" (em km²).

A classe "vegetação arbórea densa" apresentou duas situações diferentes durante o período do estudo: um decréscimo de área de 3,5\% durante 1986 a 1999 e posterior crescimento de 5\% durante o segundo período (1999 a 2010), baseando-se na área de 1999. Para o período total o crescimento foi de $1 \%$, o que demonstra que, praticamente, não houve alteração de área nos 24 anos analisados (Figura 25).

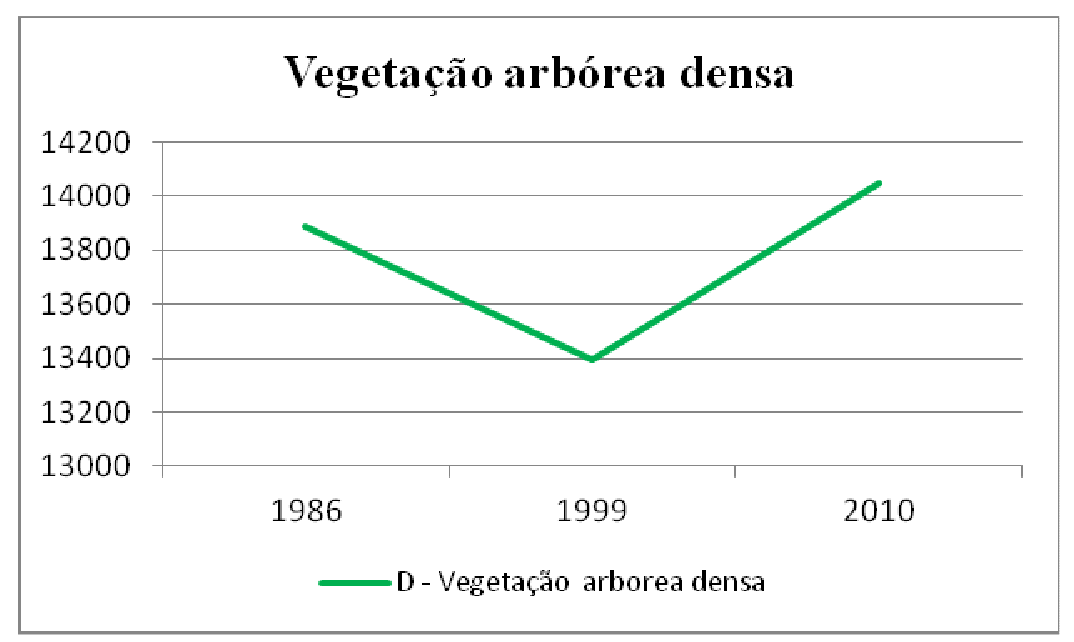

Figura 25. Evolução da classe "vegetação arbórea densa" (em $\mathrm{km}^{2}$ ). 
A "vegetação de várzea ou campo sujo" apresentou decréscimo de área durante todo o período do estudo, totalizando $35,5 \%$ de perda. Porém o decréscimo mais acentuado foi durante, segundo período (Figura 26).

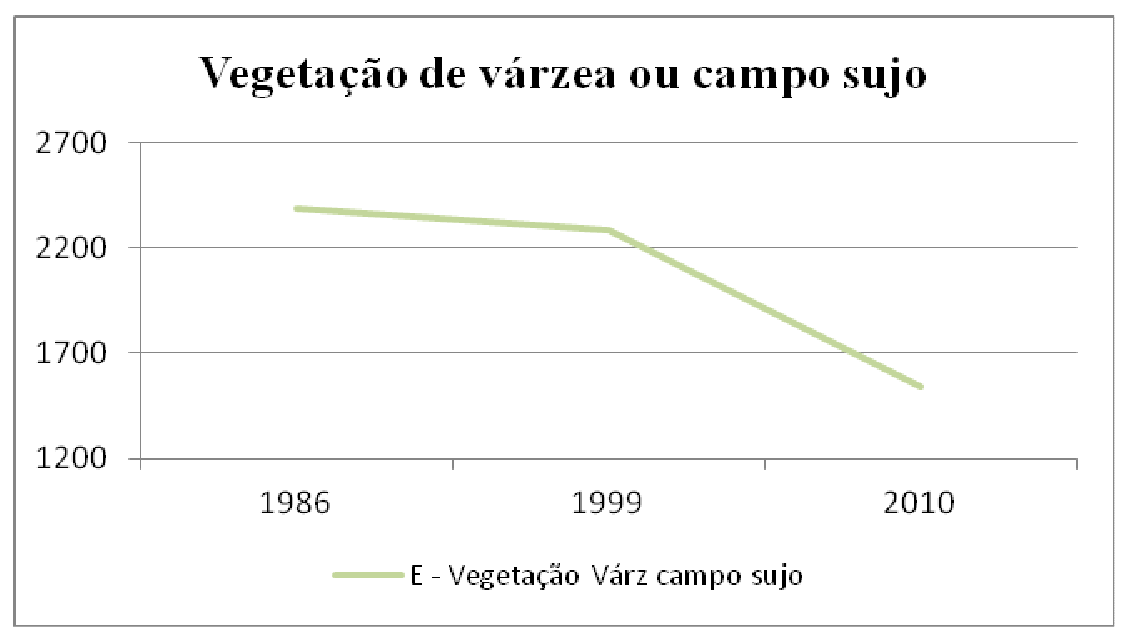

Figura 26. Evolução da classe "vegetação de várzea ou campo sujo" (em km²).

A classe "solo exposto" apresentou comportamento inverso à "vegetação arbórea densa". No primeiro período (1986-1999) recebeu um incremento de área em 173\%. Porém, na segunda etapa houve um decréscimo de 16\%. No período total (1986-2010) apresenta acréscimo de 130\% (Figura 27).

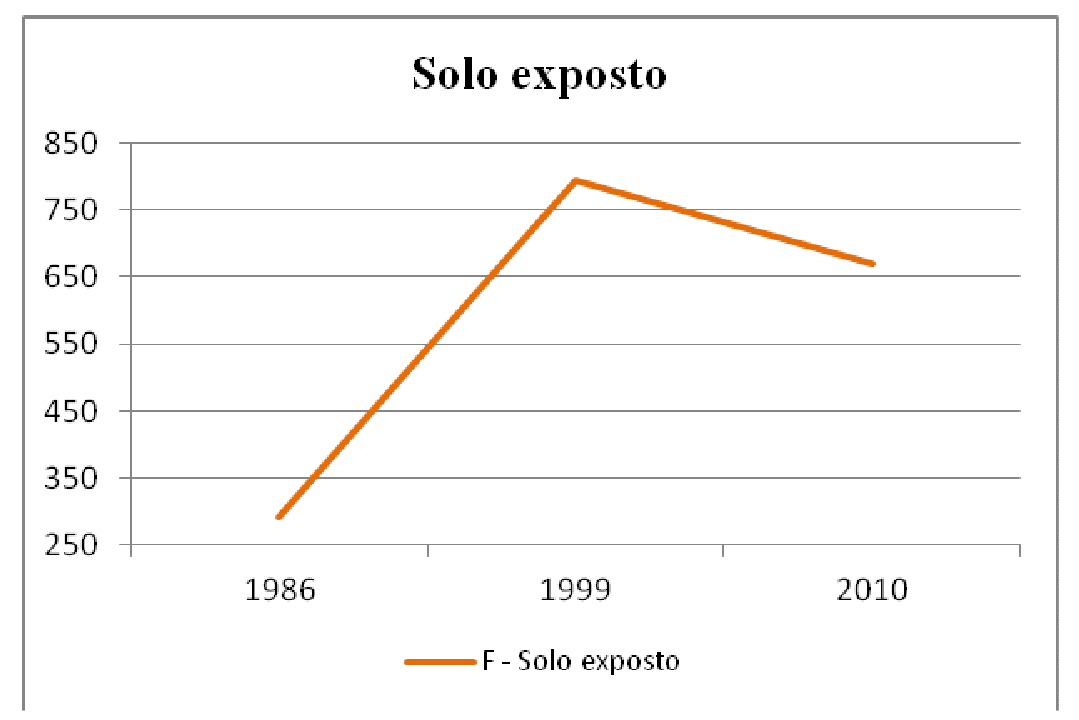

Figura 27. Evolução da classe "solo exposto" (em km²). 
O mapeamento do uso e ocupação do solo da UGRHI-11 foi realizado em parceria com o Laboratório de Geoprocessamento da Universidade Federal de Mato Grosso do Sul. Nesta etapa foram interpretadas as áreas com bananicultura nas três datas (1986, 1999 e 2010), pois a classificação não supervisionada apresentou falha ao agregar à mesma classe bananas e vegetação arbórea densa.

O mapa de uso e ocupação do solo de 2009, resultante da classificação não supervisionada, apresentou falhas na classe de vegetação arbórea densa. Para correção, realizou-se um mosaico entre o mapa de uso e ocupação do solo de 1999 com a classe vegetação arbórea densa deste mesmo ano, que primeiramente foi digitalizada sobre a cena Landsat TM. 


\section{CÁlCULO DA SUSCETIBILIDAdE A UM POTENCIAL AUMENTO NO NÍVEL DO MAR NO COMPLEXO ESTUARINO-LAGUNAR DE IGUAPE-CANANÉIA}

\subsection{INTRODUÇÃO}

A subida do nível médio do mar é um fenômeno que pode causar grandes prejuízos econômicos, sociais e ambientais. Conforme os dados do último relatório Intergovernmental Panel on Climate Change - IPCC (IPCC, 2007) o nível do mar tem aumentado com uma taxa anual de $1,8 \mathrm{~mm}$ (com variação de $0,5 \mathrm{~mm}$ para cima ou para baixo) durante o período de 1961-2003. Estes valores foram obtidos a partir de estudos baseados em dados de marégrafos situados em diferentes pontos da superfície terrestre, que enviam seus dados ao Permanent Service for Mean Sea Level - PSMSL. Os estudos do Intergovernmental Panel on Climate Change (IPCC) apontam que as taxas de elevação continuarão aumentando no próximo século, de maneira que se pode chegar a valores que representam o dobro das taxas registradas no século 20 (independentemente do cenário, com maior ou menor intervenção da emissão de gases de efeito estufa), o nível do mar seguirá subindo com taxas anuais entre 2 e $3 \mathrm{~mm}$ durante a primeira metade do século XXI (Zújar et al., 2009).

Resultado da preocupação com os potenciais impactos decorrentes de um aumento no nível médio do mar, muitas instituições supranacionais (Nações Unidas e União Europeia) e nacionais (Alemanha, Austrália, Estados Unidos da América) desenvolveram diferentes estratégias e planos com o objetivo de identificar e quantificar os potenciais efeitos da subida do nível médio do mar (Jurado, 2011).

Diferentes pesquisadores, desenvolvendo diferentes metodologias, têm trabalhado no estudo de quantificação da vulnerabilidade de um potencial aumento no nível médio do mar. Constatou-se que bastaria uma pequena elevação do nível dos oceanos para desencadear um processo de salinização de aquíferos, inundar planícies costeiras e destruir áreas urbanas (BARTH; TITUS, 1984). 


\subsection{OBJETIVOS}

Pretendeu-se modelar cartograficamente um possível aumento do nível médio do mar no Litoral Sul do Estado de São Paulo, considerando o alcance da máxima preamar. Utilizouse os modelos de Titus \& Narayanan (1995) para os anos 2025, 2050 e 2100; e os modelos do Intergovernmental Panel on Climate Change - IPCC (2007), Pfeffer (2008) e Rahmstorf (2006) para 2100.

\section{3. ÁREA DE ESTUDO}

O Complexo Estuarino-Lagunar de Iguape-Cananéia está localizado ao sul do Estado de São Paulo, na divisa com o Estado do Paraná. Sua área é de $3.414,8 \mathrm{Km}^{2}$ e o relevo varia entre zero e 1.415 metros de altitude (Figura 28).

A bacia do Ribeira de Iguape é formada por diferentes classes geomorfológicas. Ross (2002) definiu a área do Complexo Estuarino-Lagunar de Iguape-Cananéia, como o Sistema da Planície Costeira Cananéia-Iguape. Segundo este autor, esta unidade se diferencia em função de sua morfogênese e biodiversidade, onde há ocorrência de mangues, planícies e cordões arenosos marinhos.

É uma área que sofreu processos de transgressão/regressão marinha (transgressões Cananéia e Santos). Possui uma densa cobertura vegetal de Mata de porte médio, em grande parte preservada, acompanhada de franjas de vegetação de Mangue que ocupam as planícies intertidais (planícies de Mangue). É a unidade mais preservada do litoral sul do Estado de São Paulo. Além das ocupações vinculadas a uma urbanização recente de veraneio e segunda residência, estendem-se pelas margens dos canais de Cananéia e Ilha comprida vilas de populações tradicionais ribeirinhas, que se dedicam sobretudo às atividades da pesca (Ross, 2002). 


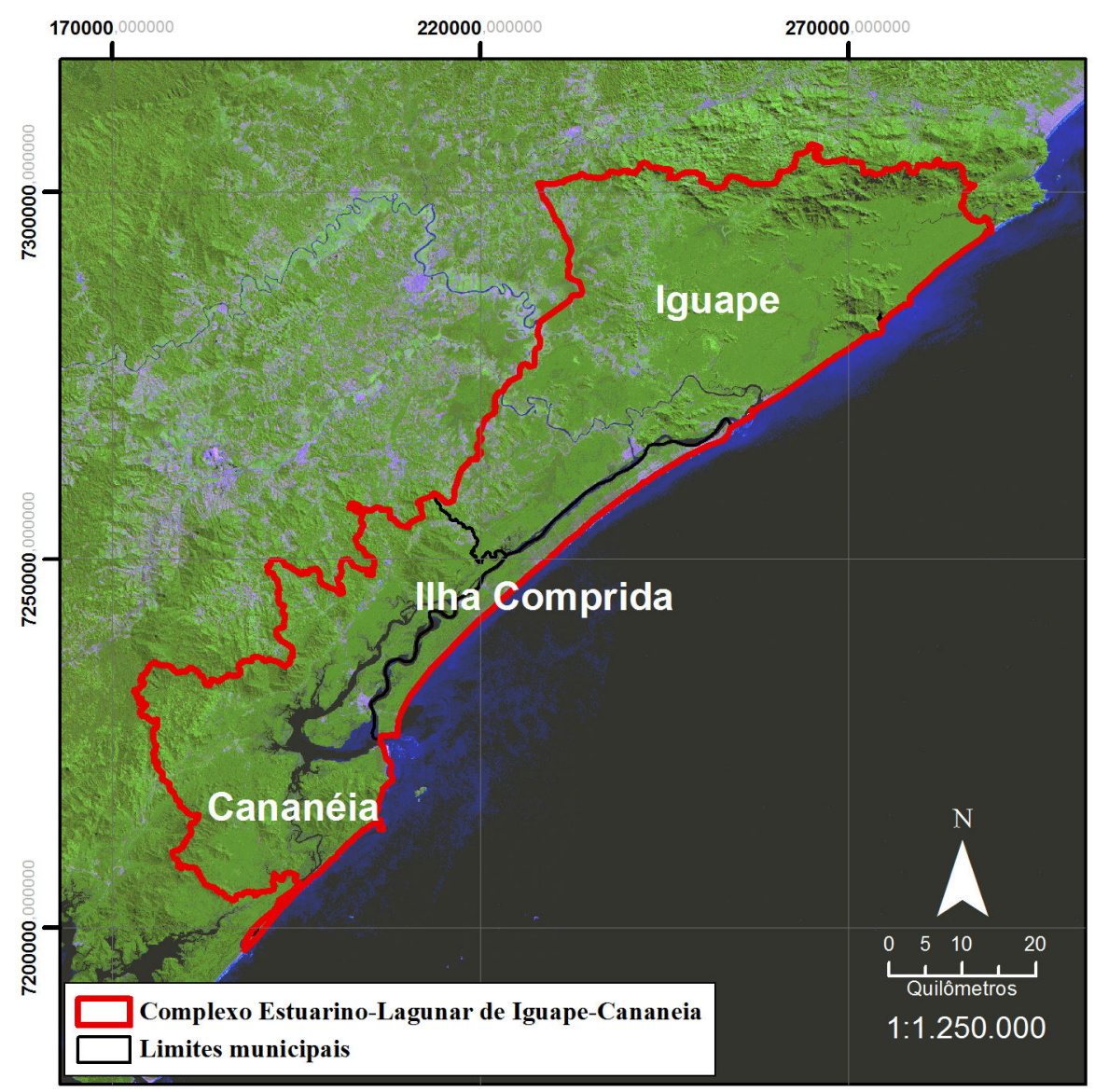

Figura 28. Área de estudo: Complexo Estuarino-Lagunar de IguapeCananéia.

\subsection{MATERIAIS E MÉTODOS}

\subsubsection{Elaboração do modelo digital de terreno}

A primeira etapa da metodologia foi a elaboração do Modelo Digital de Elevação (MDE), sobre os qual foram projetados os cenários de elevação do nível médio do mar calculados pelos métodos citados anteriormente. Para tal foi utilizada a extensão 3D Analyst, do programa ArcGis em sua versão 10 (ESRI, 2010). Neste MDE foi usada a seguinte base de dados:

- Pontos cotados extraídos de cartas topográficas na escala 1:10.000;

- Curvas de nível extraídas de cartas topográficas na escala 1:10.000;

- Curvas de nível extraídas de cartas topográficas na escala 1:50.000;

- Linha de costa vetorizada sobre uma cena do sensor SPOT, de 2011, com atribuição de cota de 1 metro.

O MDT foi elaborado com uma resolução espacial de 10 metros. 
11.4.2. Cálculo da tendência local de variação do nível médio do mar, com dados do marégrafo de Cananéia

Utilizou-se de uma longa série de registros do marégrafo de Cananéia (1954 - 2006) para o cálculo da taxa local de variação do nível médio do mar, através da técnica de regressão linear. Tais registros foram retirados do Permanent Service for Mean Sea Level PMSL (PMSL, 2012). Segundo Jurado (2011) existem diferentes metodologias para o cálculo da tendência de variação nas séries de níveis do mar de um marégrafo, tais como: regressão linear, decomposição em harmônicos e aplicação de funções empíricas ortogonais.

Jurado (2011) comparou as três técnicas e, por fim, utilizou a técnica de regressão linear pelo fato desta apresentar menor sensibilidade à falta de registros do marégrafo da área de estudo, referente a alguns anos dentro da sua série histórica de interesse. Fato semelhante ao que acontece com os dados do marégrafo de Cananéia que não apresenta registros do ano 2005. Dessa maneira, neste projeto aplicou-se a técnica de regressão linear.

A técnica de regressão linear tem como produto uma equação de primeiro grau ( $\mathrm{Y}=\mathrm{A}$ $+\mathrm{BX})$, cujo coeficiente B representa a taxa de variação anual da série de dados do marégrafo (Kendall \& Ord, 1990 apud Jurado, 2011a). Esta equação foi desenvolvida no programa EXCEL do pacote Microsoft Windows (MICROSOFT, 2007). O gráfico que representa a reta de regressão linear calculada pode ser visualizado na Figura 29.

O resultado obtido referente aos 52 anos de registros do marégrafo de Cananéia é de um acréscimo de 4,21 $\mathrm{mm}$ ao ano do nível médio do mar. Esta taxa é bastante superior à média global de $1,7 \mathrm{~mm}$ (com variação de $0,5 \mathrm{~mm}$ para mais ou para menos) referente ao último século (IPCC, 2010). Desta forma, o valor 2,51 $\mathrm{mm}$ representa o fator local, que foi calculado pela diferença entre a taxa local e a global registrada para o Século 20. 


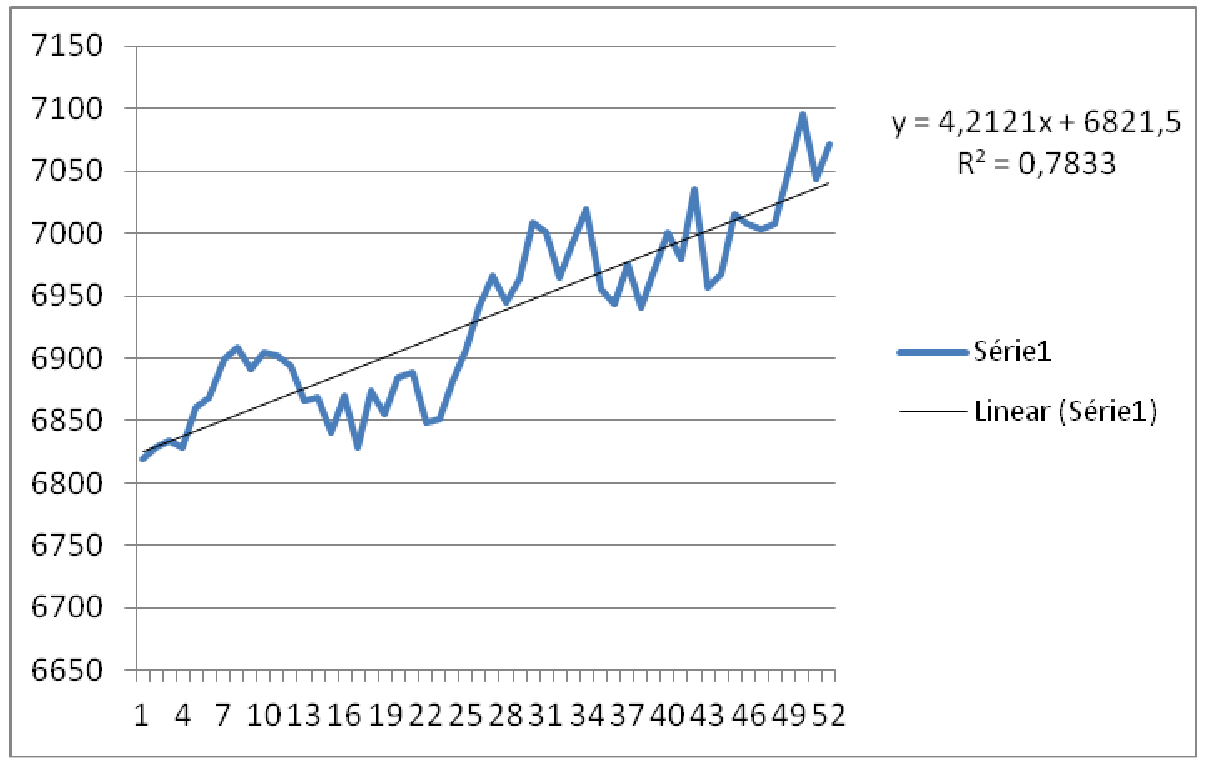

Figura 29. Análise de regressão linear sobre os registros do marégrafo de Cananéia, referente ao período $1954-2006$.

\subsubsection{Valor máximo da preamar}

Segundo dados do marégrafo de Cananéia, disponíveis na página eletrônica “TABUA DE MARES” (http://www.tabuademares.com) a preamar máxima registrada nas tabelas de marés de Cananéia que é de 1,3 m e a altura mínima -0,1 m. Desta forma, todos os modelos aplicados neste projeto consideraram o valor máximo de 1,3 m para a máxima preamar.

\subsubsection{Modelo de Titus e Narayan}

Através da aplicação do modelo de Titus \& Narayan (1998) é possível, relacionando variáveis globais e locais, estimar as variações do nível médio do mar para determinada data, baseando-se nos dados de um marégrafo. Com este modelo é possível calcular um potencial aumento do nível do mar considerando-se o nível médio do mar local e a aceleração do aumento do nível médio do mar durante o século 21. Este modelo considera o nível médio do mar resultante da expansão térmica a partir de condições estabelecidas por diferentes modelos climáticos gerados pelo IPCC e o derretimento de pequenas placas de gelo. Titus e Narayan assumem que o aumento do nível médio do mar é composto por uma componente global e outra local (Jurado, 2011). 
A componente global é composta pela emissão dos gases de efeito estufa a partir do qual, através de equações, pode-se obter a resultante de forçamento radioativo que pode desencadear uma circulação oceânica e, consequentemente, um aumento da temperatura das águas oceânicas. Deste aumento na temperatura dos oceanos podem derivar dois tipos de consequências: expansão térmica da água e o derretimento das placas de gelo. A expansão térmica é o principal fator condicionante da subida do nível médio do mar. A segunda componente, denominada local, é baseada na relação entre a componente global e as taxas locais de variação do nível médio do oceano. O modelo de Titus e Narayan é capaz de relacionar os registros locais de um marégrafo local com as projeções globais de aumento do nível do mar (Jurado, 2011).

O aumento do nível médio global do oceano, em qualquer marégrafo do planeta foi de 1,2 milímetros por ano durante o século 20 (Titus \& Narayan, 1998). Uma taxa de crescimento diferente, registrada em qualquer marégrafo do planeta, é explicada pela existência dos fatores locais. Na maior parte dos cenários de mudança do nível médio do mar espera-se uma aceleração nas taxas de subida deste nível de acordo com as taxas registradas no século 20. Para Titus e Narayan ao combinar as taxas locais registradas em cada marégrafo com as expectativas futuras de alteração do nível do mar é preciso observar que durante o século 20 existiram fatores globais, aparentemente ligados às mudanças climáticas, que podem variar durante as próximas décadas. Porém, estes autores assumem que os fatores locais não variarão durante os próximos anos, pois estes fatores apresentam uma escala temporal muito mais ampla (Jurado, 2011).

Deste modo, quando em posse dos dados locais de taxa de variação do nível do mar, basta conhecer o valor que está previsto para, no futuro, o nível do mar local subir ou descer, considerando-se o valor registrado durante o século 20 (1,2 $\mathrm{mm}$ ao ano). O modelo de Titus \& Narayan é um modelo normalizado utilizado para evitar de considerar duas vezes a contribuição dos fatores globais do século 20, erro que ocorreria se os valores referentes ao fatores locais, que já consideram a influência global, aos valores referentes aos fatores globais (Jurado, 2011). Neste modelo basta incluir o valor da tendência local à seguinte Equação 2: 
Eq. 2. Local $(\mathrm{t})=\mathrm{T}$ Normalizado $+(\mathrm{t}-1990) \mathrm{x}$ Tendência local

Onde:

- Local (t) é o cenário local futuro, no momento “t”, baseando-se nas expectativas globais de variação do nível do mar.

- T normalizado é o cenário do modelo normalizado para o momento “t”, o qual já consta a eliminação da componente global do século 20 .

- "t" é o ano para o qual é calculada a expectativa.

- Tendência local é a taxa linear registrada no marégrafo.

De acordo com este modelo, o ano referência para projetar cenários futuros é 1990. Na Tabela 18 estão os valores referentes ao fator $\mathrm{T}$ normalizado, elaborados por Titus \& Narayan (1998).

Tabela 18. Valores normalizados de variação do nível do mar (centímetros), onde já foi eliminada a componente global de subida no nível médio do mar durante o século 20. A coluna da probabilidade apresenta a variação de influência dos fatores globais. Fonte: Titus \& Narayan (1998) apud Jurado (2011).

\begin{tabular}{ccccccc}
\hline Probabilidade (\%) & 2025 & 2050 & 2075 & 2100 & 2150 & 2200 \\
\hline 99 & -10 & -16 & -21 & -24 & -32 & -40 \\
95 & -3 & -4 & -5 & -6 & -7 & -8 \\
90 & -1 & -1 & 0 & 1 & 3 & 5 \\
80 & 1 & 3 & 6 & 10 & 16 & 23 \\
70 & 3 & 6 & 10 & 16 & 26 & 37 \\
60 & 4 & 8 & 14 & 20 & 35 & 51 \\
50 & 5 & 10 & 17 & 25 & 43 & 64 \\
40 & 6 & 13 & 21 & 30 & 53 & 78 \\
30 & 8 & 15 & 24 & 36 & 65 & 98 \\
20 & 9 & 18 & 29 & 44 & 80 & 125 \\
10 & 12 & 23 & 37 & 55 & 106 & 174 \\
5 & 14 & 27 & 43 & 66 & 134 & 231 \\
2,5 & 17 & 31 & 50 & 78 & 167 & 296 \\
1 & 19 & 35 & 57 & 92 & 210 & 402 \\
Média & 5 & 11 & 18 & 27 & 51 & 81 \\
\hline
\end{tabular}




\subsubsection{Modelo de Pfeffer}

Pfeffer et al. (2008) utilizando-se de modelagem climática, e baseando-se em registros do passado, propuseram um modelo de aumento do nível do mar para o final do século 21 , baseado na contribuição do degelo das calotas polares. Neste estudo foram consideradas as condições glaciológicas para estimar o nível do mar em 2100. Os autores concluíram que aumentos superiores a 2 metros são fisicamente insustentáveis. Este aumento poderia ser atingido num cenário em que todas as variáveis envolvidas fossem aceleradas para altos limites. A maior possibilidade é de um aumento de 0,8 metros até 2100 .

A metodologia foi baseada em projeções de derretimento e descarga de gelo no oceano, onde este processo foi acelerado com diferentes velocidades que, segundo os autores têm influência direta no aumento do nível médio dos mares. Para obter a estimativa global do futuro nível do mar, os autores consideraram no seu modelo o aumento projetado pelo IPCC (2007). Pfeffer, Harper e O’Neel propõem três cenários que combinam métodos de prováveis projeções.

No Cenário 1 (Low 1), que representa uma pequena elevação do nível do mar, a projeção foi realizada baseando-se em ajustes específicos nas áreas polares potencialmente vulneráveis ao processo de degelo. Os valores de velocidade de derretimento das geleiras da Groenlândia e da Pine Island Glacier foram duplicados em relação às taxas atuais, nenhuma alteração neste dado foi considerada para a região de Lambert/Amery. Assim, no Cenário 1, o resultado é de um aumento no nível médio do mar de 785 milímetros, em 2100. Para a criação do Cenário 2 (Low 2), os autores estimaram a contribuição da Groenlândia como calculado para o Low 1, porém reduziram a influência do processo de degelo na Antártica. Todavia, a contribuição total referente ao degelo das geleiras e calotas desencadeia um maior aumento no nível do mar, no Cenário 2, de forma que o resultado líquido, incluindo a expansão térmica, é um aumento de 833 milímetros em 2100. O Cenário 3 (High 1) combina a influência das áreas da Groenlândia, Antártica, geleiras e calotas, porém projetando altos valores de aceleração do processo de degelo para todas essas áreas. O resultado líquido, incluindo a expansão térmica, para o cenário High 1 é de 2008 mm por 2100 Pfeffer et al. (2008).

Nesta pesquisa de tese, utilizaram-se os valores de Pfeffer (Cenários 1, 2 e 3) como valor global e adicionou-se a influência local, de acordo com a Equação 3. 
Eq. 3. Local $(2100)=$ Cenário Pfeffer $+[$ Fator local x $(2100-1990)$

Onde:

- Local (2100) é o cenário local projetado para 2100.

- Cenário Pfeffer, neste campo foram inseridos os valores de: Cenário $1(78,5 \mathrm{~cm})$, Cenário 2 (83,3 cm) e Cenário $3(200,8 \mathrm{~cm})$.

- Fator local é a taxa local linear registrada no marégrafo, produto do resultado da subtração da Taxa Total Local subtraída do Fator Global.

- 1990 é o ano base da análise. O resultado da equação será somado ao nível médio do mar em Cananéia, registrado no marégrafo local.

\subsubsection{Modelo de Rahmstorf}

Rahmstorf (2006) cita que os modelos atuais baseados em dados físicos são muito limitados para calcular futuras alterações no nível médio dos oceanos em consequência de determinado cenário de aquecimento da superfície terrestre, além destes modelos não serem aptos a reproduzir totalmente o aumento do nível médio dos oceanos para as últimas décadas. Diferente do comportamento dos modelos baseados em dados físicos, os modelos semiempíricos podem ser uma alternativa para estimar a resposta do nível do mar frente a um aquecimento da superfície terrestre. Neste trabalho, Rahmstorf apresenta os resultados de uma relação semi-empírica entre o aumento do nível médio do mar com a temperatura média da superfície terrestre e propõe que há uma relação direta de maneira que constatou que durante o século 20, um aumento de 3,4 milímetros ao ano por grau Celsius. Paralelamente, aplicou seus resultados sobre os cenários futuros de aquecimento do IPCC (2007) e obteve a elevação global do nível médio do mar em 2100 entre 0,5 a 1,4 metros acima do nível médio de 1990.

Seguindo as considerações de Rahmstorf (2006), neste projeto de tese aplicaram-se duas equações para modelar o aumento global de $0,5 \mathrm{~m}$ ou 1,4 m (Equação 4), para o ano de 2100. 
Eq. 4. Local $\left(2100_{z}\right)=Z+[$ Fator Local $x(2100-1990)$

Onde:

- Local (2100) é o cenário local projetado para 2100 para os cenários calculados pelo método de Rahmstorf.

- Z é o aumento global de Rahmstorf que será utilizado na equação centímetros (50 ou 140 centímetros).

- Fator local é a taxa local linear registrada no marégrafo $(2.51 \mathrm{~mm})$.

\subsubsection{Modelo Intergovernmental Panel on Climate Change (IPCC)}

No último relatório publicado pelo Intergovernmental Panel on Climate Change Working Group I: The Physical Science Basis (IPCC, 2007) projetou-se que o nível médio do mar sofrerá uma elevação até o final do Século 21. O valor desta elevação varia muito: 0,18 0,38 m (Cenário B1); 0,20 - 0,43 m (Cenário B2); 0,21 - 0,48 m (Cenário A1B); 0,20 - 0,45 m (Cenário A1T); 0,20 - 0,51 m (Cenário A2); e 0,26 - 0,59 m (Cenário A1F1). Em todos os cenários a taxa média de crescimento durante o Século 21 excede a taxa registrada entre 19612003 (1,8 mm por ano, com variação de $0,5 \mathrm{~mm}$ a mais ou para menos). De acordo com o Cenário A1B, entre 2090 e 2099 a estimativa é de um aumento de 3,8 mm ao ano. De acordo com os dados publicados neste relatório do IPCC, num modelo médio o cenário de aumento do nível do mar é de apenas $2 \mathrm{~cm}$ para o ano 2050 e $15 \mathrm{~cm}$ para o final do século.

Em todos cenários do IPCC, a expansão térmica apresenta a maior influência no aumento do nível do mar, contribuindo entre 70 a 75\% do valor total. Neste relatório há a citação de que alguns modelos indicam que a camada de gelo da Antártida receberá um acréscimo, ganhando massa e contribuindo negativamente para a elevação do nível do mar. Processos de aceleração de formação de gelo observados em algumas geleiras da Groelândia e em alguns riachos da Antártica podem aumentar substancialmente a formação de geleiras. $\mathrm{O}$ relatório conclui que o aumento do nível do mar durante o Século 21 é projetado para variar geograficamente. Os diferentes modelos de cenários não são iguais, porém apresentam algumas características em comum, por exemplo, menor aumento do nível médio do mar no Oceano Antártico, que será maior que no Ártico, e um aumento do nível por todo o sul do Oceano Atlântico e Índico (IPCC, 2007). 
$\mathrm{Na}$ metodologia aplicada neste projeto de tese, utilizou-se uma série que abrange o valor mínimo de subida do mar projetado pelo Cenário B1 e o valor máximo referente ao Cenário AIFI. Dessa maneira, trabalhou-se com a variação de $0,18-0,59 \mathrm{~m}$, como aumento global, para o ano 2100, conforme a Equação 5.

Eq. 5. Local $\left(2100_{0,18}\right)=18+[$ Fator Local x $(2100-1990)$

Onde:

- Local (2100) é o cenário local projetado para 2100 para os cenários calculados pelo método do IPCC.

- Z é o aumento global do IPCC que será utilizado na equação centímetros (18 ou 59 centímetros).

- Fator local é a taxa local linear registrada no marégrafo $(2.51 \mathrm{~mm})$.

\subsection{RESULTADOS}

Neste capítulo serão apresentados os valores dos máximos níveis do mar, no Litoral Sul do Estado de São Paulo, para cada um dos métodos citados anteriormente. Para tais cálculos foram considerados o valor máximo da preamar em Cananéia (1,3 m).

\subsubsection{Aplicação do modelo de Titus e Narayan}

A equação de Titus e Narayan (Eq. 2) foi aplicada utilizando-se o valor de 0,42 centímetros no campo Tendência local e o nível médio do mar em Cananéia, em 1990 (1,72 metros), para os anos de 2025, 2050 e 2100, de forma que foram realizados cálculos para as probabilidades de $99 \%, 50 \%$ e 1\%. Como o ano de referência é 1990 , no campo "t" da Equação 2 foram colocados os valores: 35 para o cálculo do nível médio do mar no ano de 2025; 60 para calcular o nível de 2050; e 110 para calcular o nível de 2100. Os resultados podem ser observados na Tabela 19. 
Tabela 19. Resultado da aplicação da equação de Titus e Narayan para os anos de 2025, 2050 e 2100 (em centímetros).

\begin{tabular}{cccc}
\hline Probabilidade (\%) & 2025 & 2050 & 2100 \\
\hline 99 & 4,7 & 9,2 & 22,2 \\
50 & 19,7 & 35,2 & 71,2 \\
1 & 33,7 & 60,2 & 138,2 \\
\hline
\end{tabular}

Aos valores contidos na Tabela 19 foi somado o nível médio do mar em Cananéia no ano referência (1990), que foi calculado em 172 centímetros (Tabela 20). Posteriormente, aos valores obtidos na Tabela 20 foi somado o valor referente ao máximo preamar (Tabela 21).

Tabela 20. Resultado da soma entre os valores obtidos da aplicação da equação de Titus e Narayan e o valor médio do nível do mar em Cananéia (1990) para os anos de 2025, 2050 e 2100 (em centímetros).

\begin{tabular}{cccc}
\hline Probabilidade $(\%)$ & 2025 & 2050 & 2100 \\
\hline 99 & 177,6 & 182,1 & 195,1 \\
50 & 192,6 & 208,1 & 244,1 \\
1 & 206,6 & 233,1 & 311,1 \\
\hline
\end{tabular}

Tabela 21. Resultado da soma entre os valores da Tabela 20 e máxima preamar $(130 \mathrm{~cm})$, para os anos de 2025, 2050 e 2100 (em centímetros).

\begin{tabular}{cccc}
\hline Probabilidade (\%) & 2025 & 2050 & 2100 \\
\hline 99 & 307,6 & 312,1 & 325,1 \\
50 & 322,6 & 338,1 & 374,1 \\
1 & 336,6 & 363,1 & 441,1 \\
\hline
\end{tabular}

\subsubsection{Probabilidades do modelo e elaboração dos mapas}

O modelo de Titus e Narayan permite a modelagem do nível médio do mar no horizonte temporal de interesse do usuário, considerando as probabilidades. Jurado (2011) cita que a maioria dos mapas apresentados em teses de doutorado foram calculados com uma probabilidade de $50 \%$, ou seja, que há $50 \%$ de chance que em " $\mathrm{t}$ " anos o nível do mar do modelo seja ultrapassado. 
Para esta modelagem do futuro nível médio do mar no Litoral Sul do Estado de São Paulo foram eleitas as probabilidades de $99 \%, 50 \%$ e $1 \%$, este último o mais improvável e que implica níveis mais altos. As datas escolhidas para as modelagens foram 2025, 2050 e 2100 e as respectivas áreas inundadas são apresentadas na Tabela 22.

Tabela 22. Área inundada pela máxima preamar para os anos 2025, 2050 e 2100 (em $\mathrm{km}^{2}$ ). Fonte: Elaboração própria.

\begin{tabular}{cccc}
\hline Probabilidade (\%) & 2025 & 2050 & 2100 \\
\hline 99 & 453 & 459 & 474 \\
50 & 472 & 488 & 522 \\
1 & 487 & 512 & 581 \\
\hline
\end{tabular}

\subsection{Modelagem referente ao ano 2025}

Neste item serão apresentados os mapas elaborados para o ano 2025 considerando as probabilidades de 1\%, 50\% e 99\%, que serão apresentadas sobrepostas nas Figuras 30 e 31.

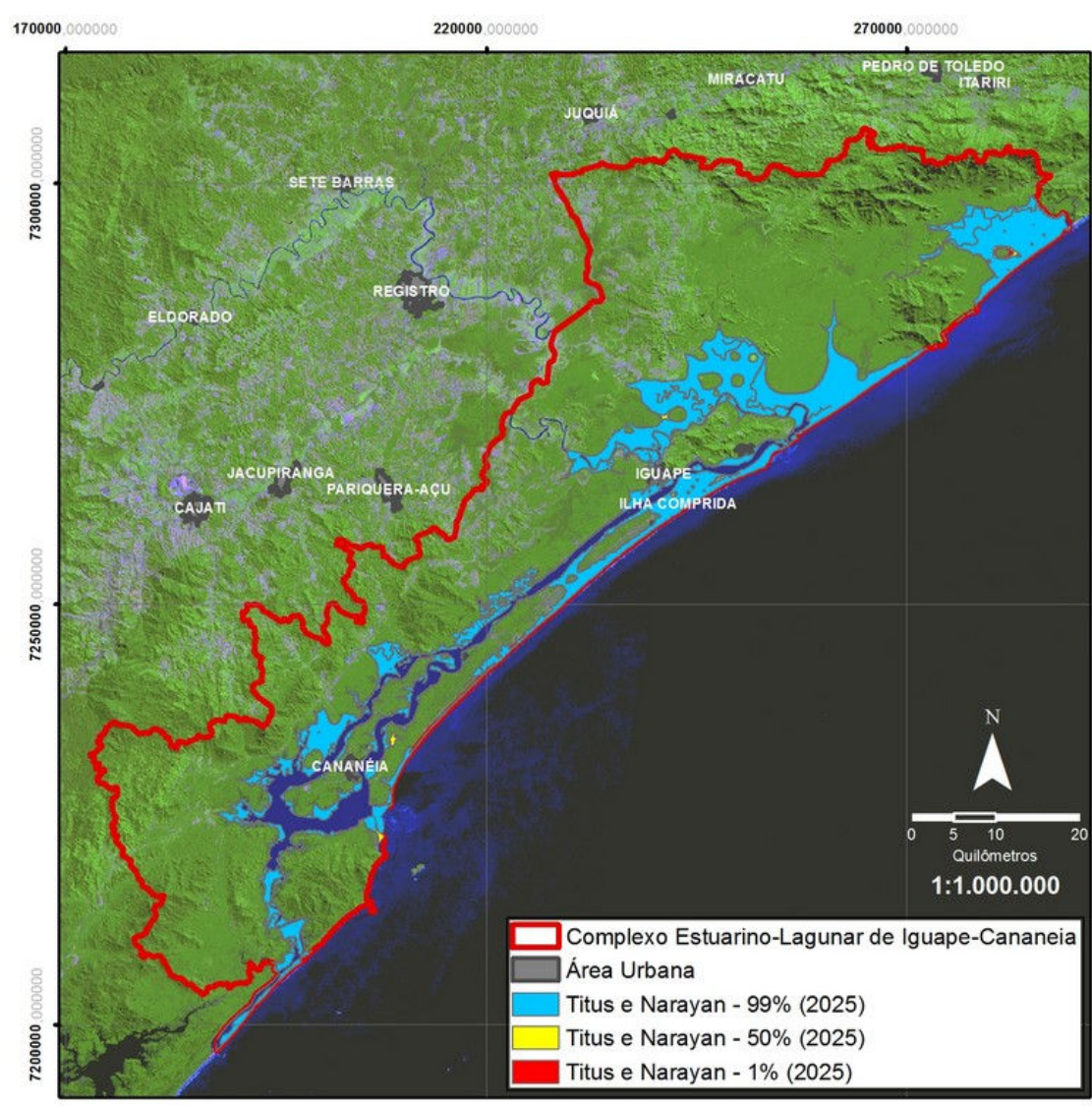

Figura 30. Modelo de Titus e Narayan aplicado ao ano 2025 sobre as probabilidades de $99 \%, 50 \%$ e $1 \%$. Imagem de fundo - Cena Landsat 5 TM de 19/11/2010. 


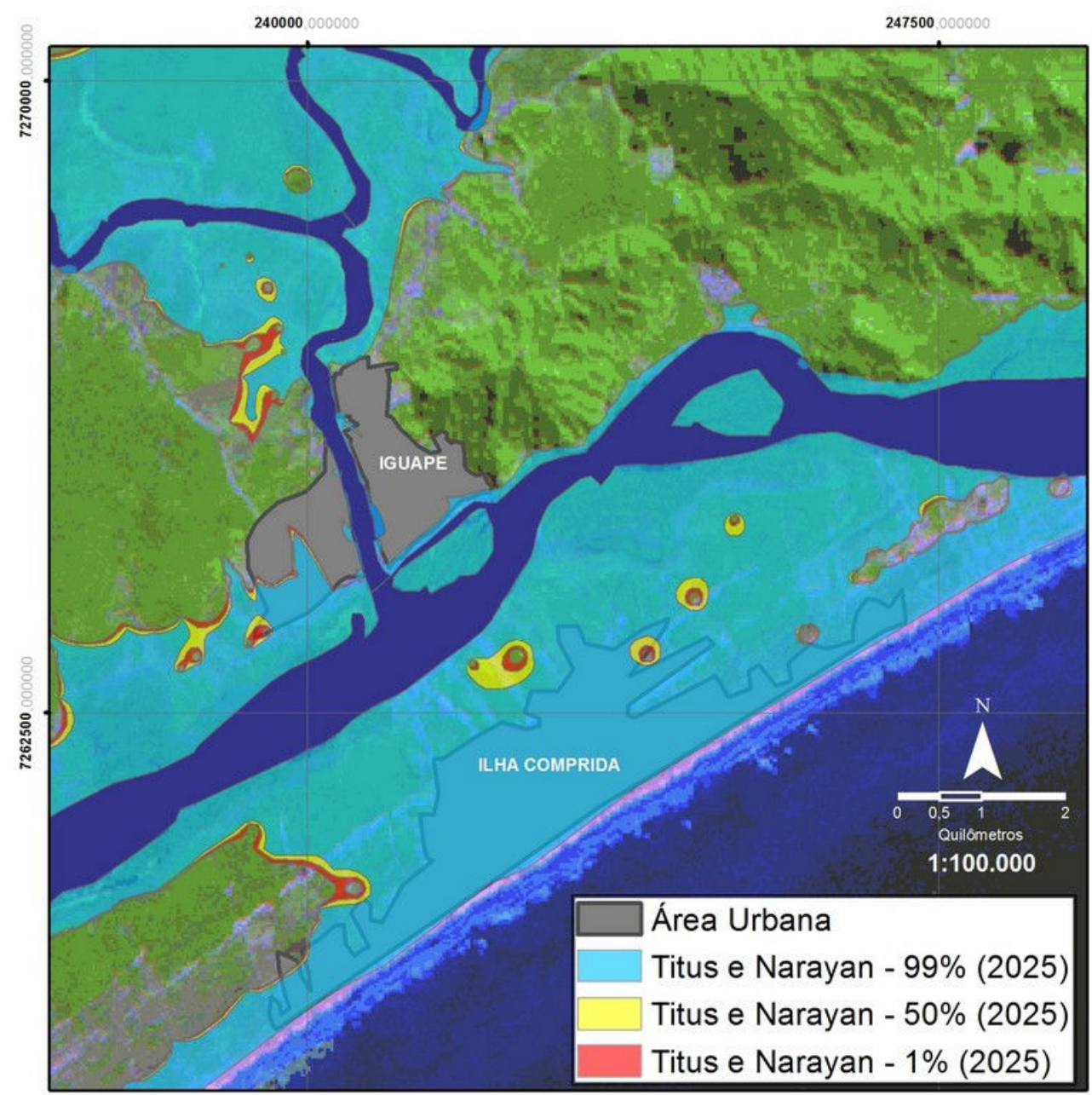

Figura 31. Modelo de Titus e Narayan aplicado ao ano 2025 sobre as probabilidades de $99 \%, 50 \%$ e $1 \%$. Imagem de fundo - Cena Landsat $5 \mathrm{TM}$ de 19/11/2010.

\subsection{Modelagem referente ao ano 2050}

Neste item serão apresentados os mapas elaborados para o ano 2050 considerando as probabilidades de 1\%, 50\% e 99\%, que serão apresentadas sobrepostas nas Figuras 32 e 33. 


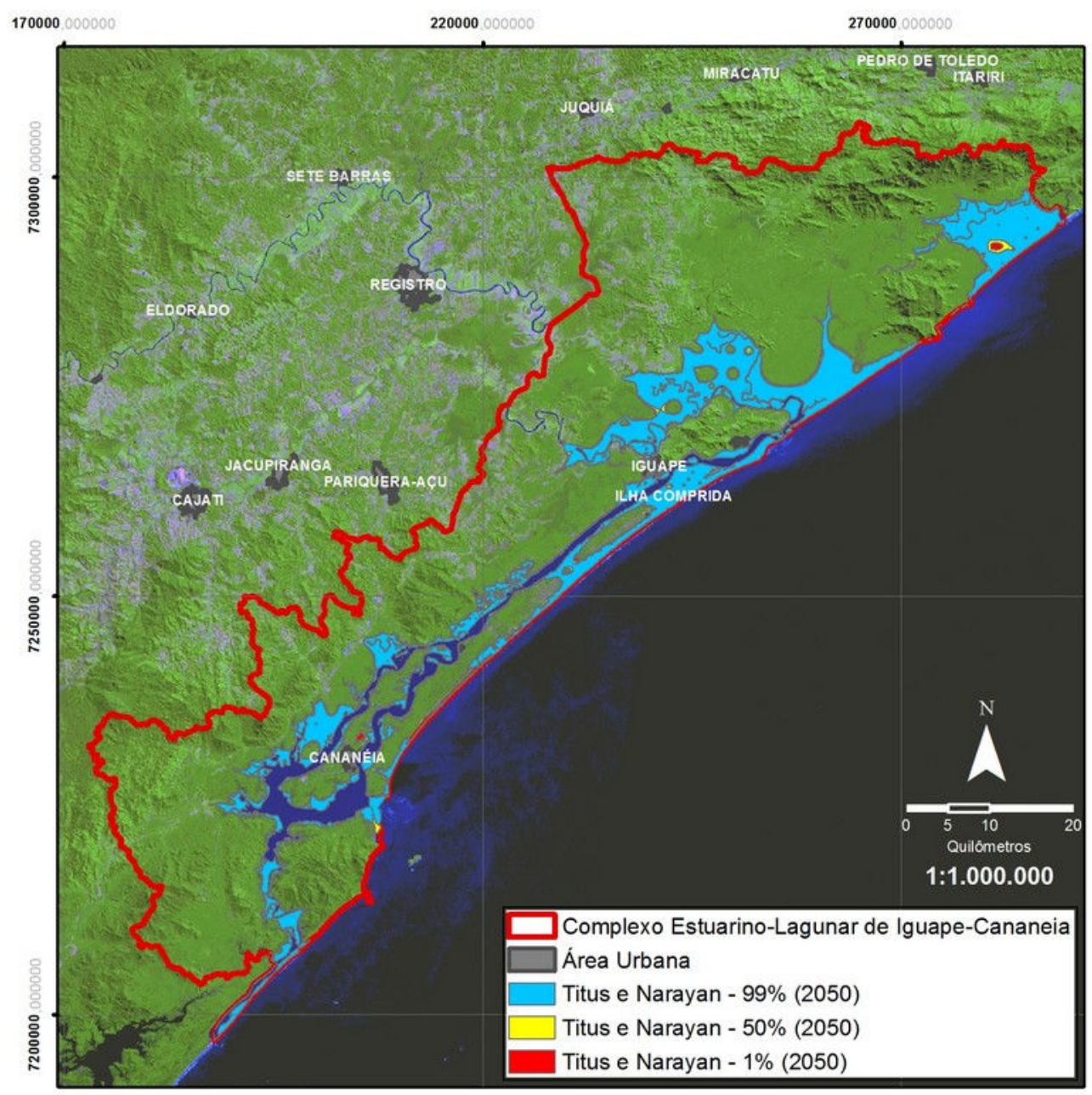

Figura 32. Modelo de Titus e Narayan aplicado ao ano 2050 sobre as probabilidades de $99 \%, 50 \%$ e $1 \%$. Imagem de fundo - Cena Landsat 5 TM de 19/11/2010. 


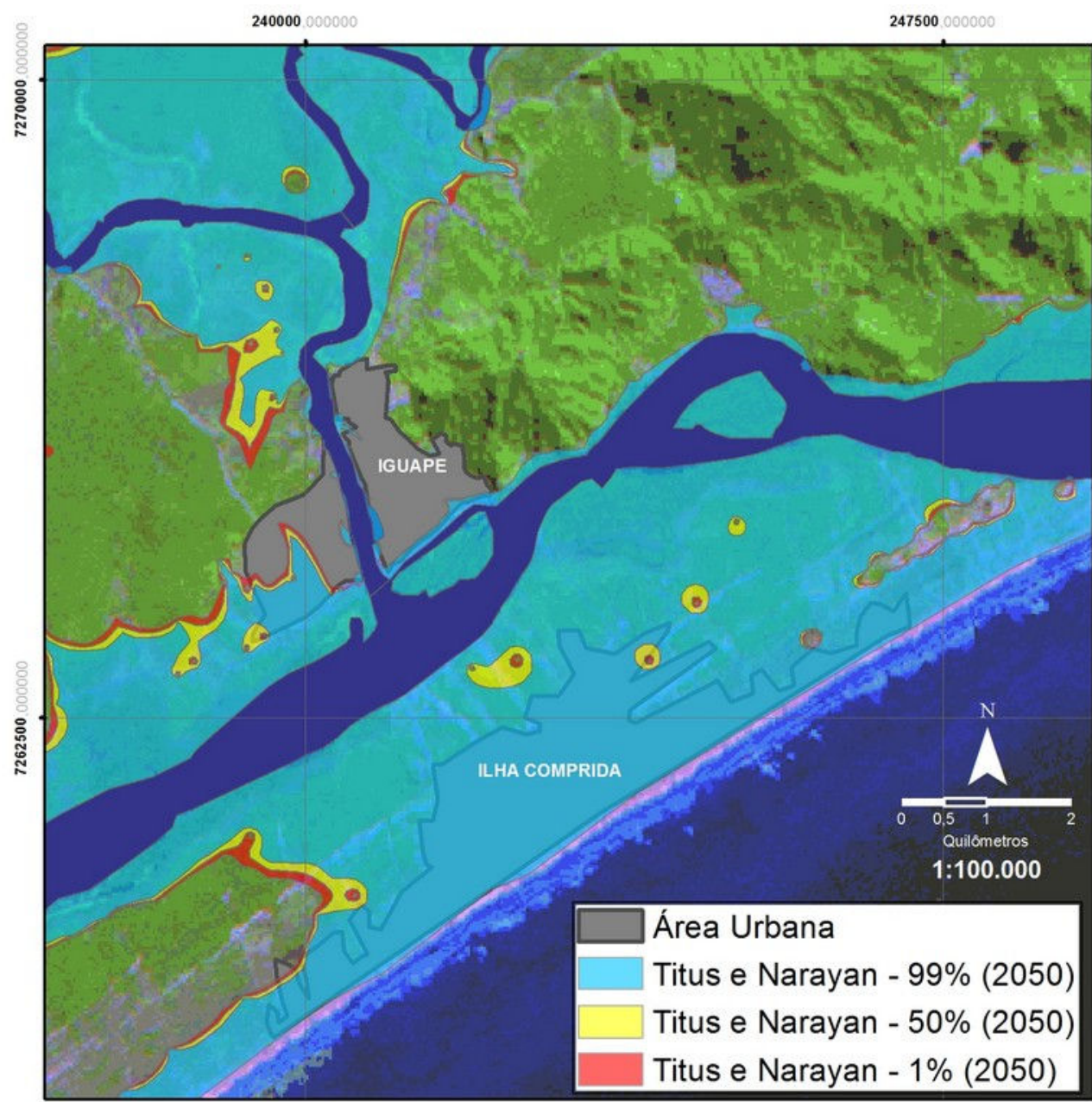

Figura 33. Modelo de Titus e Narayan aplicado ao ano 2050 sobre as probabilidades de $99 \%, 50 \%$ e $1 \%$. Imagem de fundo - Cena Landsat 5 TM de 19/11/2010. 


\subsection{Modelagem referente ao ano 2100}

Neste item serão apresentados os mapas elaborados para o ano 2100 considerando as probabilidades de 1\%, 50\% e 99\%, que serão apresentadas sobrepostas nas Figuras 34 e 35.

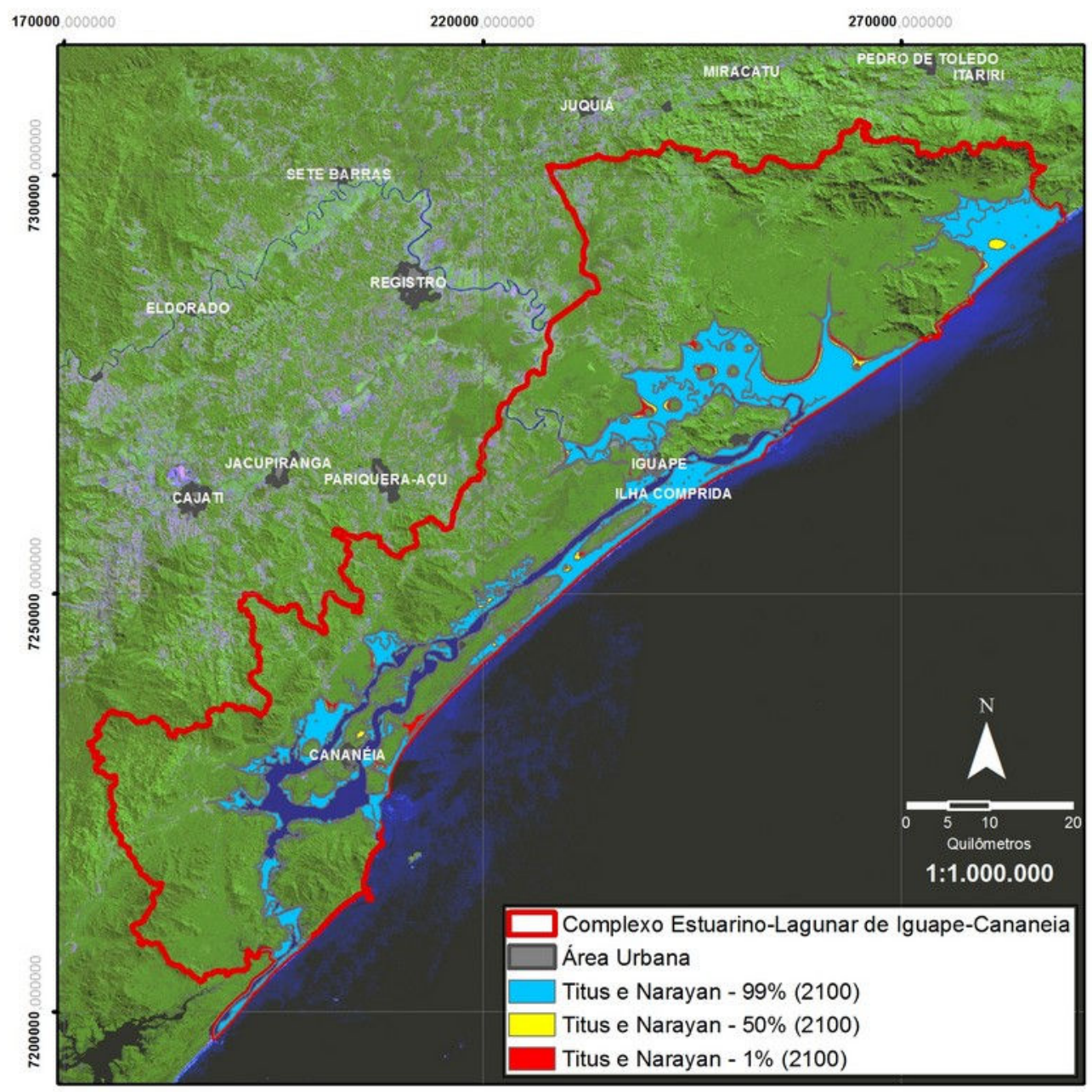

Figura 34. Modelo de Titus e Narayan aplicado ao ano 2100 sobre as probabilidades de $99 \%, 50 \%$ e $1 \%$. Imagem de fundo - Cena Landsat 5 TM de 19/11/2010. 


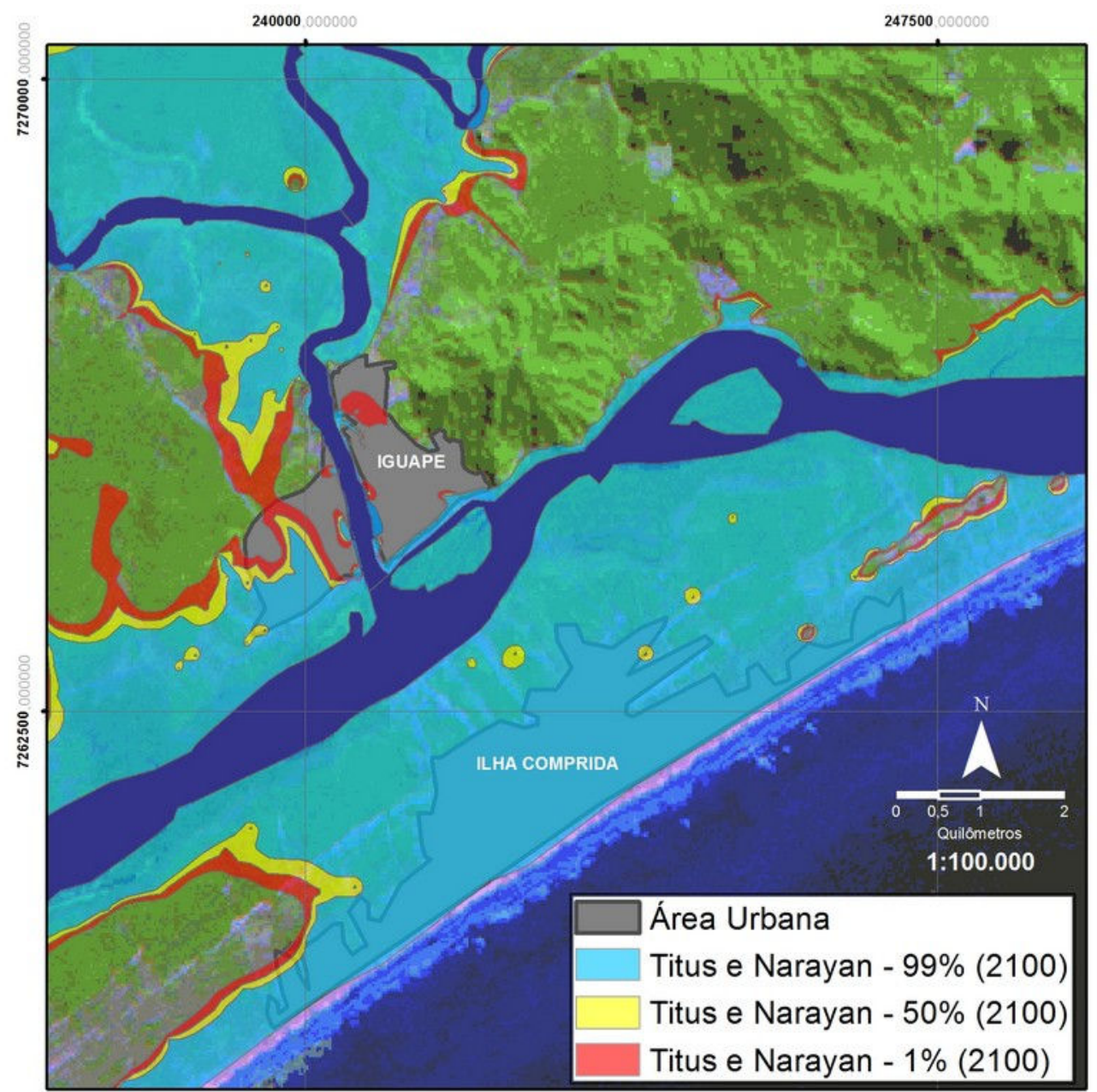

Figura 35. Modelo de Titus e Narayan aplicado ao ano 2100 sobre as probabilidades de $99 \%, 50 \%$ e $1 \%$. Imagem de fundo - Cena Landsat 5 TM de 19/11/2010.

\subsubsection{APLICAÇÃO DO MODELO DE PFEFFER}

A equação de Pfeffer (Eq. 3) foi aplicada utilizando-se o valor de 0,25 centímetros no campo Tendência local. Os produtos desta equação foram somados ao nível médio do mar, registrado no marégrafo de Cananéia em 1990 (1,72 metros). O resultado da equação aplicada para os Cenários de Pfeffer pode ser visualizado na Tabela 23. Como o ano de referência é 1990 e os cenários de Pfeffer foram calculados para 2100, o valor 110 foi inserido na equação como o tempo de projeção. 
Tabela 23. Resultado da Eq. 3 (em centímetros).

\begin{tabular}{cc}
\hline Cenários & 2100 \\
\hline Elevação global de $78,5 \mathrm{~cm}$ & 106 \\
Elevação global de $83,3 \mathrm{~cm}$ & 110,8 \\
Elevação global de $200,8 \mathrm{~cm}$ & 228,3 \\
\hline
\end{tabular}

O resultado da soma entre os valores obtidos da equação de Pfeffer, mais o valor médio do nível do mar em Cananéia (em 1990) e a máxima preamar, pode ser visualizado na Tabela 24. Na Tabela 25 estão contidos os valores das áreas cobertas pela máxima preamar, em 2100, de acordo com os Cenários de Pfeffer.

Tabela 24. Resultado da soma entre os valores obtidos da aplicação da equação de Pfeffer, nível médio em 1990 e a máxima preamar (em centímetros).

\begin{tabular}{cc}
\hline Cenários & 2100 \\
\hline Elevação global de $78,5 \mathrm{~cm}$ & 409 \\
Elevação global de $83,3 \mathrm{~cm}$ & 414 \\
Elevação global de $200,8 \mathrm{~cm}$ & 531 \\
\hline
\end{tabular}

Tabela 25. Área inundadas pela máxima preamar, em 2100, dos Cenários de Pfeffer $\left(\mathrm{em} \mathrm{km}^{2}\right)$.

\begin{tabular}{cc}
\hline Cenários & 2100 \\
\hline Elevação global de $78,5 \mathrm{~cm}$ & 552 \\
Elevação global de $83,3 \mathrm{~cm}$ & 558 \\
Elevação global de $200,8 \mathrm{~cm}$ & 675 \\
\hline
\end{tabular}




\subsubsection{Modelagem de Pfeffer referente ao ano 2100}

Neste item serão apresentados os mapas elaborados para o ano 2100 para o Cenário 1, Cenário 2 e Cenário 3, sobrepostos (Figura 36 e 37).

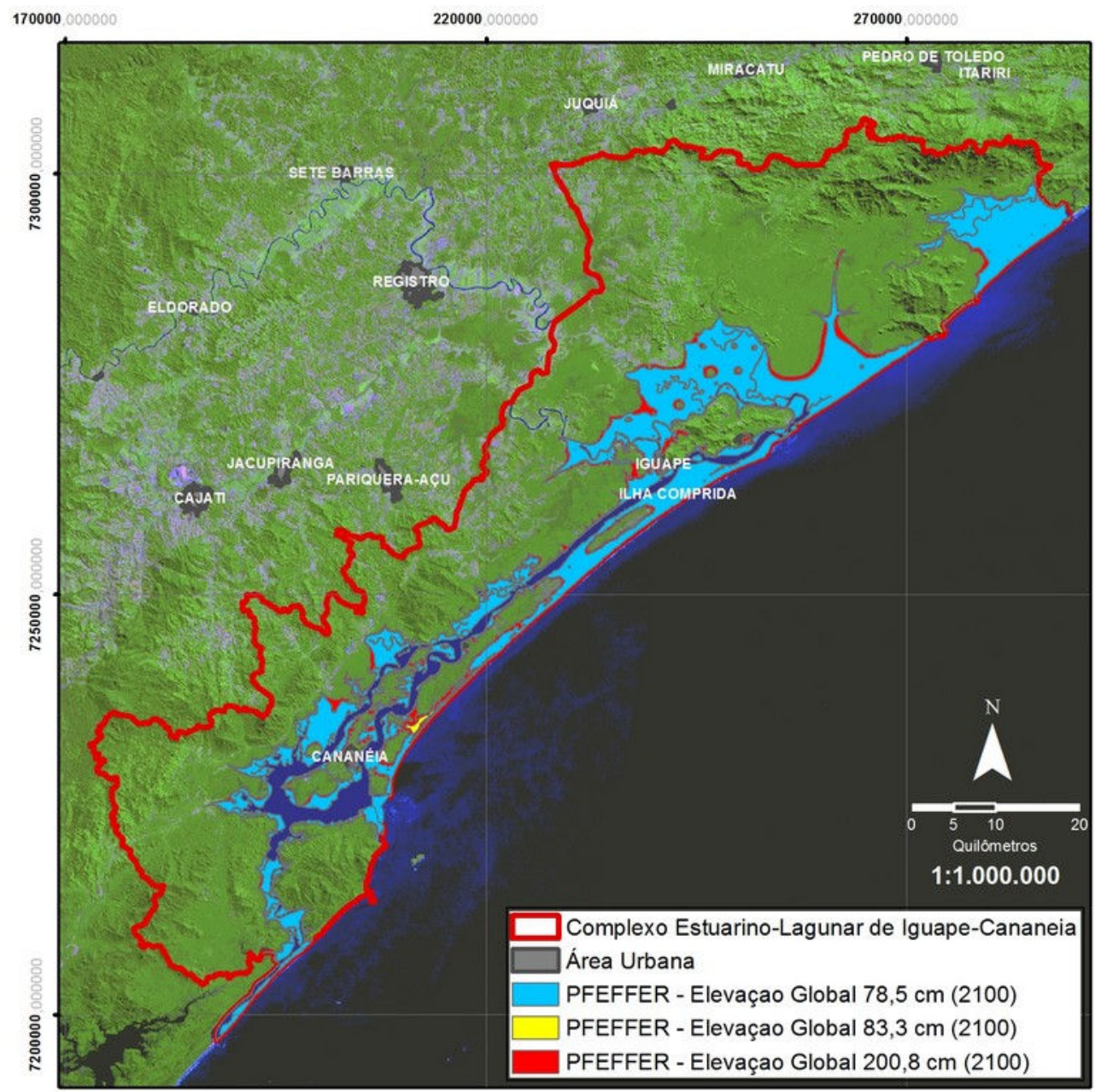

Figura 36. Modelo de Pfeffer aplicado ao ano 2100. Imagem de fundo - Cena Landsat 5 TM de 19/11/2010. 


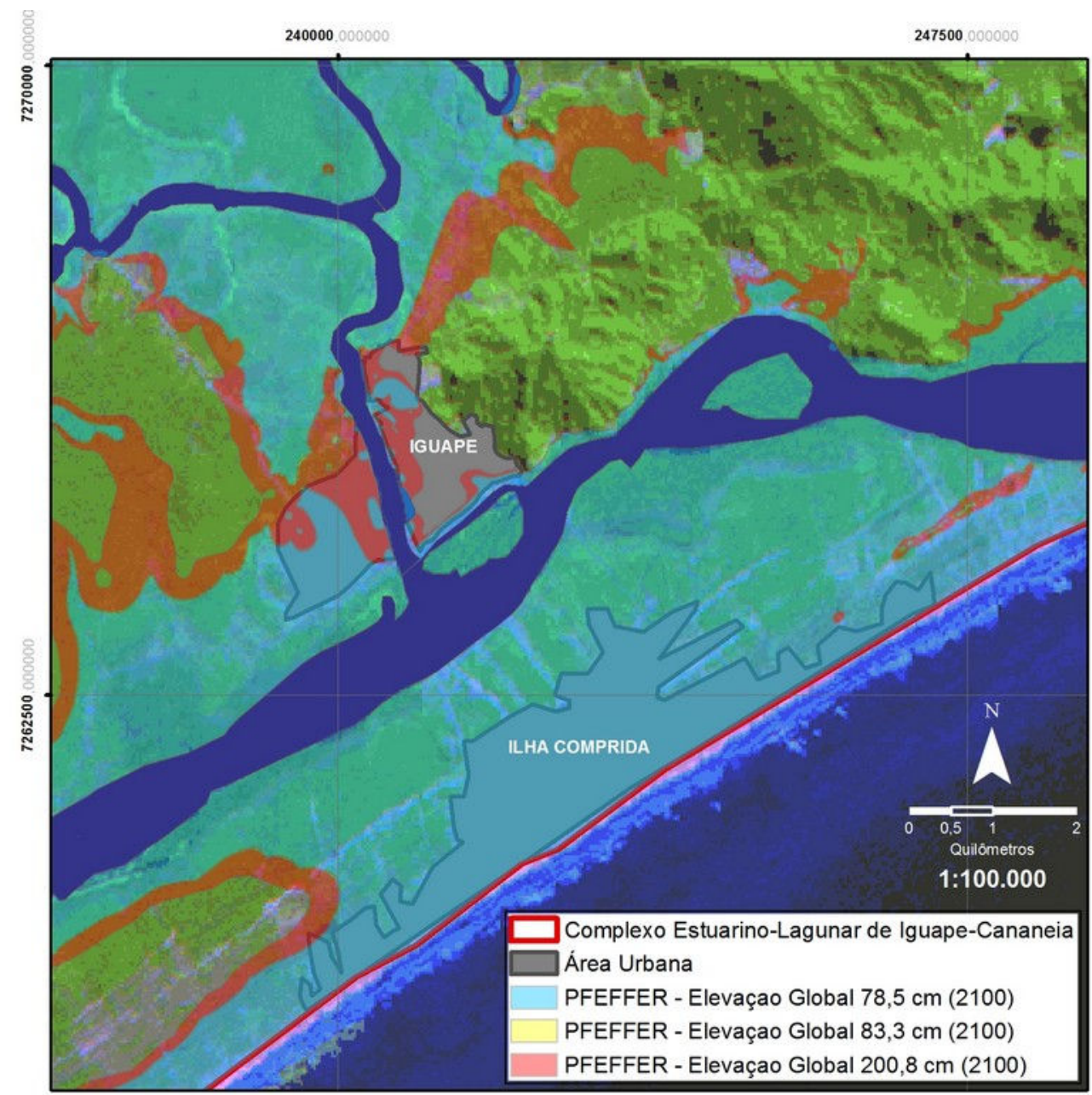

Figura 37. Modelo de Pfeffer aplicado ao ano 2100. Imagem de fundo - Cena Landsat 5 TM de 19/11/2010.

\subsubsection{Aplicação do modelo de Ramhstorf}

A equação de Ramhstorf (Eq. 4) foi aplicada utilizando-se o valor de 0,25 centímetros no campo fator local de aumento do nível médio do mar em Cananéia. Os produtos desta equação foram somados ao nível médio do mar, registrado no marégrafo de Cananéia em 1990 (1,72 metros). O resultado da equação aplicada para os Cenários de Ramhstorf pode ser visualizado na Tabela 26. Semelhante à equação de Pfeffer, como o ano de referência é 1990 e os cenários de Ramhstorf foram calculados para 2100, o valor 110 foi inserido na equação como o tempo de projeção. 
Tabela 26. Resultado da soma entre os valores obtidos da aplicação da equação de Ramhstorf (em centímetros).

\begin{tabular}{cc}
\hline Cenários & 2100 \\
\hline Elevação global de $0,5 \mathrm{~m}$ & 250 \\
Elevação global de $1,4 \mathrm{~m}$ & 340 \\
\hline
\end{tabular}

O resultado da soma entre os valores obtidos da equação de Ramhstorf, mais o valor médio do nível do mar em Cananéia (em 1990) e a máxima preamar, pode ser visualizado na Tabela 27. Na Tabela 28 estão contidos os valores das áreas cobertas pela máxima preamar, em 2100.

Tabela 27. Resultado da soma entre os valores obtidos da aplicação da equação de Ramhstorf, nível médio em 1990 e a máxima preamar (em centímetros).

\begin{tabular}{cc}
\hline Cenários & 2100 \\
\hline Elevação global de $0,5 \mathrm{~m}$ & 380 \\
Elevação global de $1,4 \mathrm{~m}$ & 470 \\
\hline
\end{tabular}

Tabela 28. Área inundadas pela máxima preamar, em 2100, dos Cenários de Ramhstorf (em km²).

\begin{tabular}{cc}
\hline Cenários & 2100 \\
\hline Elevação global de $0,5 \mathrm{~m}$ & 527 \\
Elevação global de $1,4 \mathrm{~m}$ & 607 \\
\hline
\end{tabular}




\subsubsection{Modelagem de Ramhstorf referente ao ano 2100}

Os mapas elaborados para o ano 2100 referente a um potencial aumento global do nível do mar de 0,5 ou 1,4 m, sobrepostos podem ser visualizados nas Figuras 38 e 39.

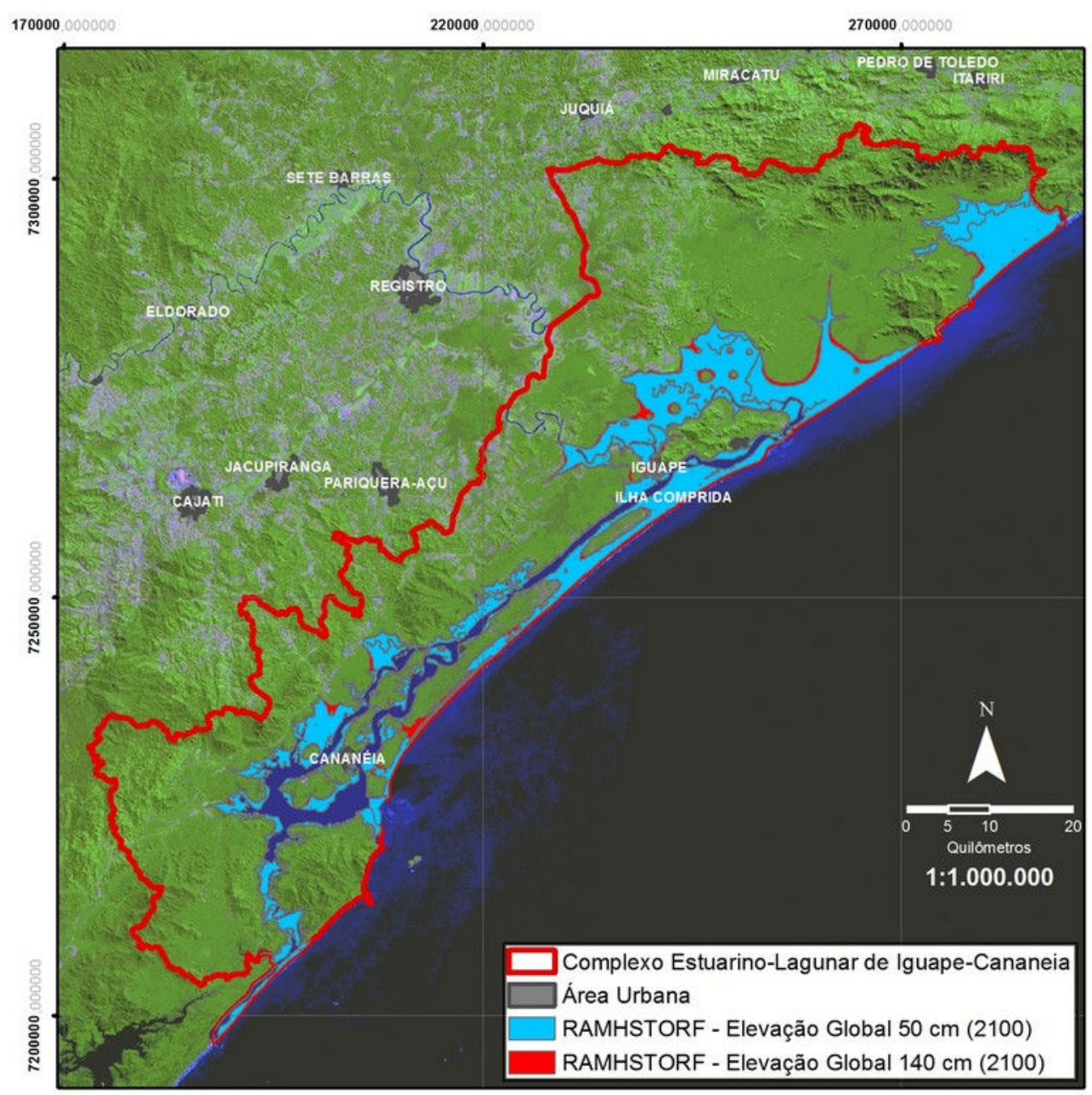

Figura 38. Modelo de Ramhstorf aplicado ao ano 2100. Imagem de fundo Cena Landsat 5 TM de 19/11/2010. 


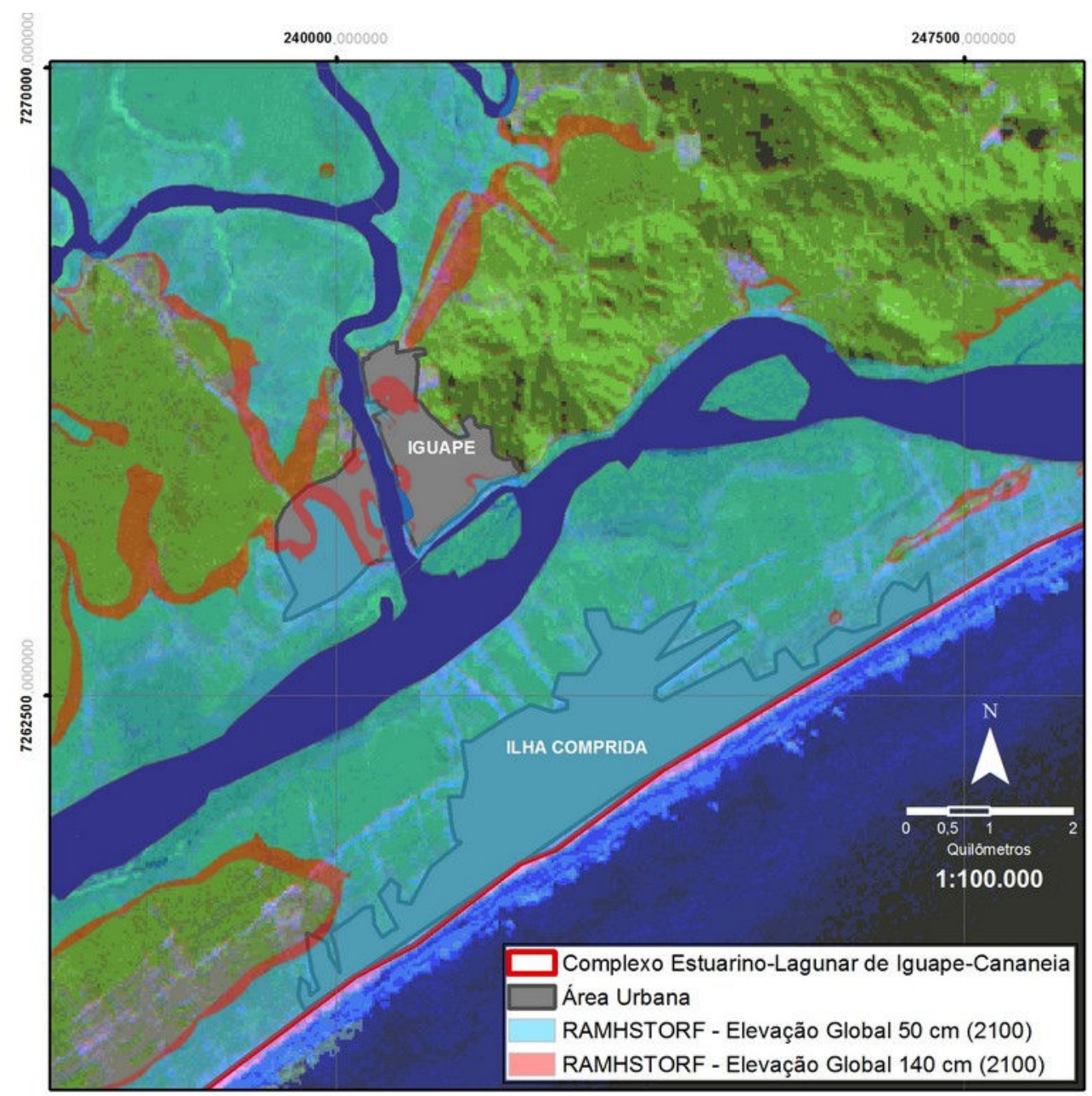

Figura 39. Modelo de Ramhstorf aplicado ao ano 2100. Imagem de fundo Cena Landsat 5 TM de 19/11/2010.

\subsubsection{Aplicação do modelo IPCC}

Semelhante aos modelos de Pfeffer e Ramhstorf, no modelo do IPCC também se utilizou o valor de 0,25 centímetros no campo fator local de aumento do nível médio do mar em Cananéia (Eq. 5). O resultado da soma entre os valores obtidos da equação do modelo do IPCC, mais o valor médio do nível do mar em Cananéia (em 1990) e a máxima preamar, pode ser visualizado na Tabela 29. Na Tabela 30 estão contidos os valores das áreas cobertas pela máxima preamar, em 2100. 
Tabela 29. Resultado da soma entre os valores obtidos da aplicação da equação de IPCC, nível médio em 1990 e a máxima preamar (em centímetros).

\begin{tabular}{cc}
\hline Cenários & 2100 \\
\hline Elevação global de $0,18 \mathrm{~m}$ & 348 \\
Elevação global de $0,59 \mathrm{~m}$ & 389 \\
\hline
\end{tabular}

Tabela 30. Área inundadas pela máxima preamar, em 2100, referente ao modelo do IPCC $\left(\mathrm{em} \mathrm{km}^{2}\right)$.

\begin{tabular}{cc}
\hline Cenários & 2100 \\
\hline Elevação global de $0,18 \mathrm{~m}$ & 498 \\
Elevação global de $0,59 \mathrm{~m}$ & 535 \\
\hline
\end{tabular}




\subsubsection{Modelagem de IPCC referente ao ano 2100}

Os mapas elaborados para o ano 2100 referente a um potencial aumento global do nível do mar de 0,18 ou 0,59 m, sobrepostos podem ser visualizados nas Figuras 40 e 41 .

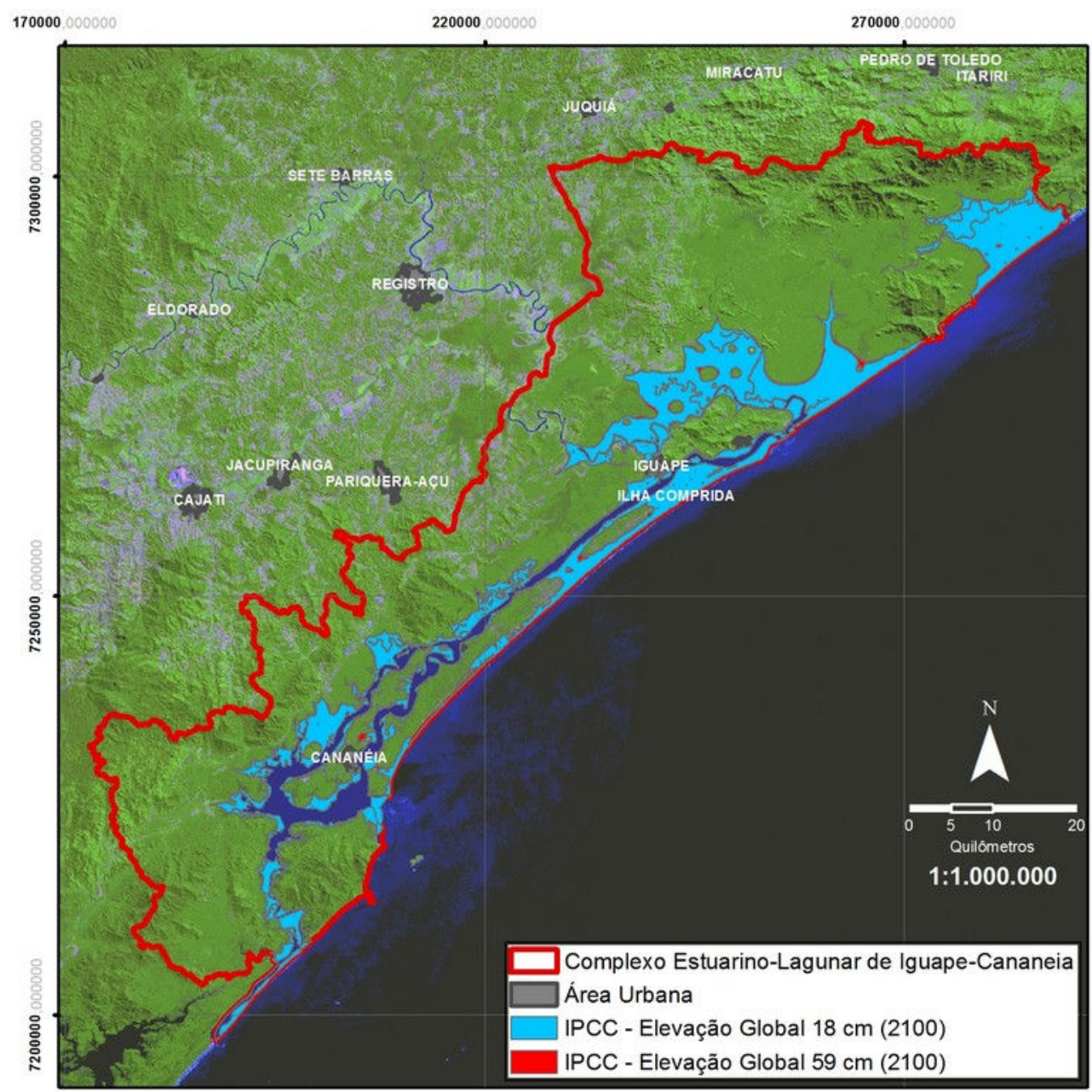

Figura 40. Modelo do IPCC aplicado ao ano 2100. Imagem de fundo - Cena Landsat 5 TM de 19/11/2010. 


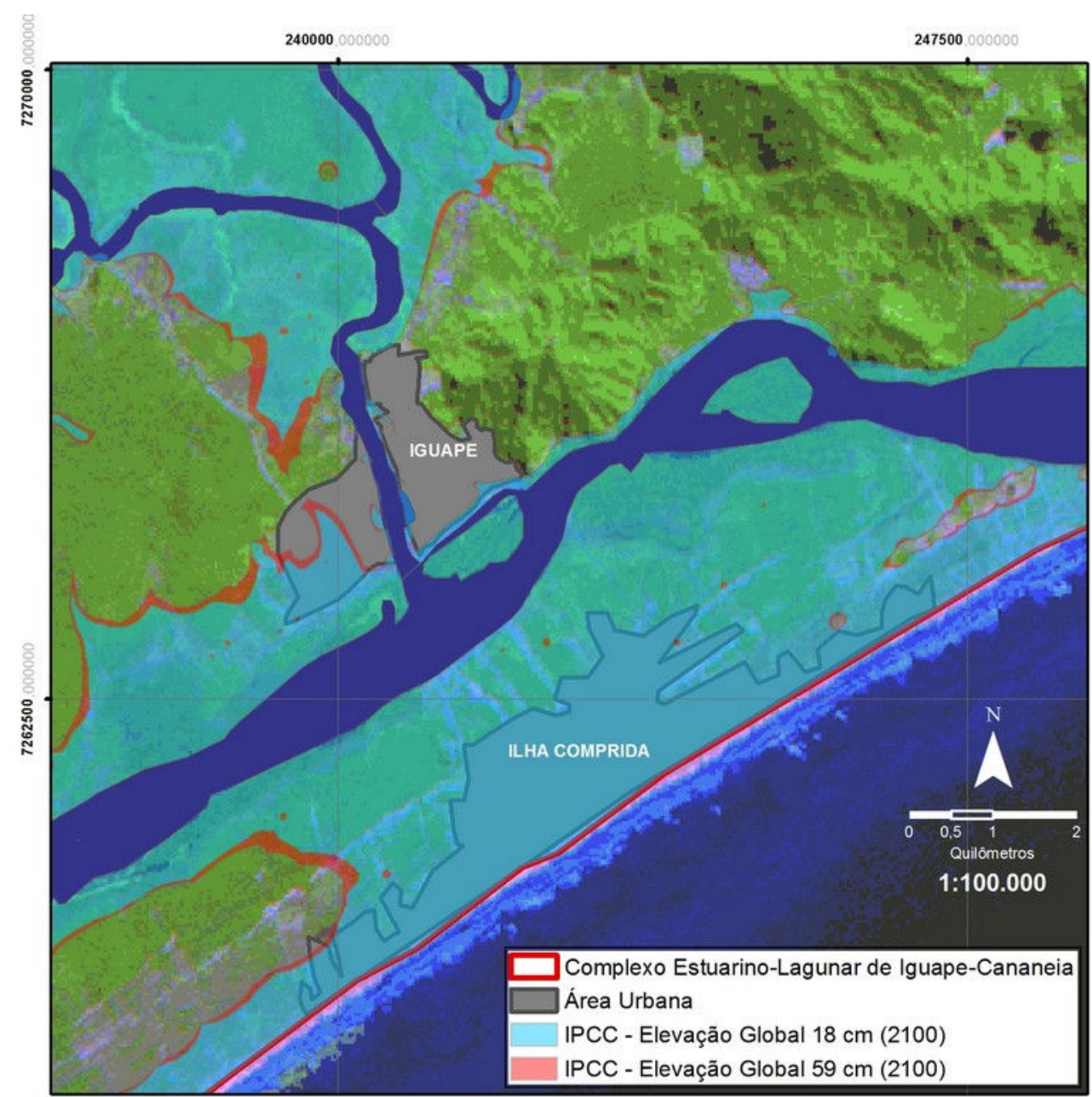

Figura 41. Modelo do IPCC aplicado ao ano 2100. Imagem de fundo - Cena Landsat 5 TM de 19/11/2010.

\subsection{Discussões}

Os resultados da aplicação de todos os modelos utilizados neste projeto corroboram com a afirmação de Rahmstorf (2007), que critica o modelo do IPCC por ser demasiadamente conservador e não refletir adequadamente a incerteza em relação ao derretimento dos mantos de gelo da Groelândia e Antártida. Comparando os resultados das projeções mais pessimistas de todos os modelos, o menor resultado obtido é da equação do IPCC (Tabela 31). 
Tabela 31. Projeção de todos os métodos para a máxima preamar em 2100.

\begin{tabular}{lc}
\hline \multicolumn{1}{c}{ MODELOS } & $\begin{array}{c}\text { PROJEÇÃO }-2100 \\
(\mathrm{~cm})\end{array}$ \\
\hline IPCC & 389 \\
PFEFFER & 531 \\
RAMHSTORF & 470 \\
TITUS E NARAYANAN & 441 \\
\hline
\end{tabular}

A comparação entre a área atingida para cada método, em 2100, aplicando os cenários (modelos) mais pessimistas pode ser visualizada na Figura 42.

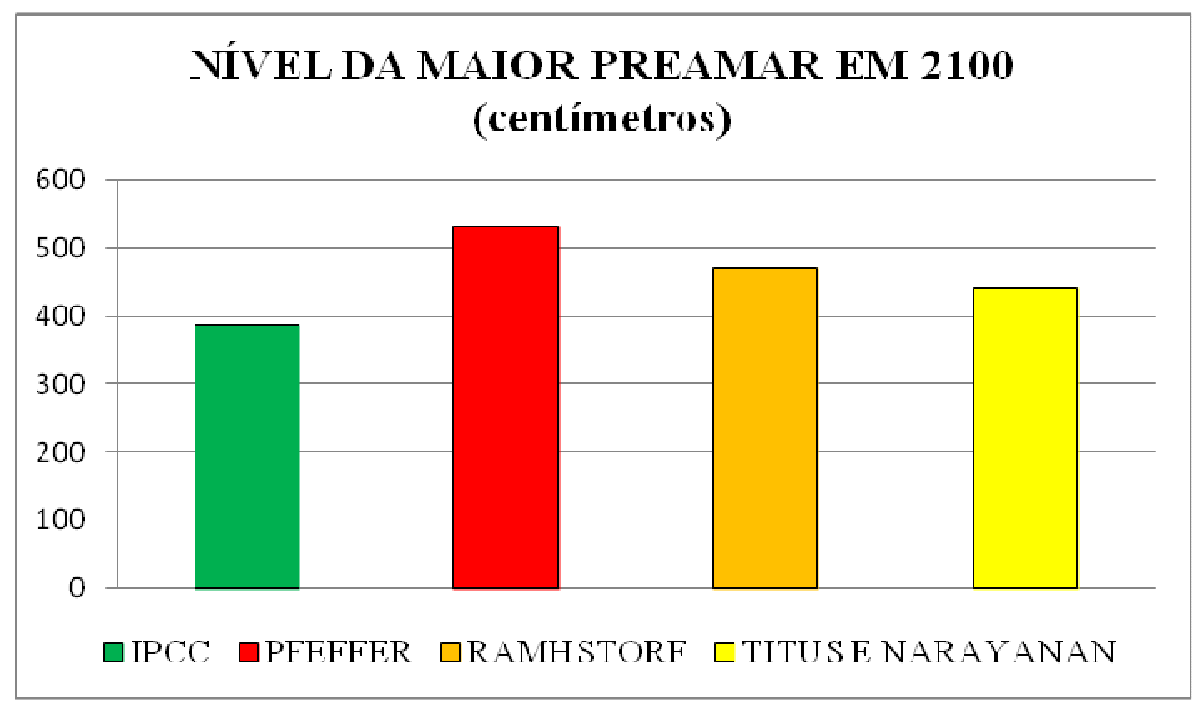

Figura 42. Projeção de todos os métodos para a máxima preamar em 2100 $\left(\mathrm{em} \mathrm{km}^{2}\right)$. 


\section{APLICAÇÃO DE GEOTECNOLOGIAS NA ELABORAÇÃO DE CENÁRIOS FUTUROS DE USO E OCUPAÇÃO DO SOLO NO VALE DO RIBEIRA DE IGUAPE E LITORAL SUL DO ESTADO DE SÃO PAULO, PARA 2025}

A metodologia aqui descrita foi utilizada na avaliação da evolução da relação entre tipo e intensidade das classes de uso e ocupação do solo (1986, 1999 e 2010), prever o cenário da distribuição das classes de uso e ocupação do solo em 2025. Esta simulação foi realizada através dos métodos de cadeias de Markov, calibração do modelo de simulação e cadeias de Markov, acopladas a um algoritmo de autômato celular, no programa IDRISI Andes (Eastman, 2006), baseando-se nas pesquisas de Terra (2010), e Valente \& Vettorazzi (2008).

Para simulação do uso e ocupação do solo em 2010 utilizou-se os mapas de 1986/1987 e 1999, gerados no processo de classificação automática. Os agentes modificadores da paisagem e suas respectivas causas motoras, que foram utilizados neste processo de simulação são:

- Declividade: $\mathrm{Na}$ área de estudo a declividade está diretamente ligada à localização da maioria das unidades habitacionais e áreas agrícolas. Porém, há casos de residências localizadas em áreas de alto declive que, em vários casos, acabam tornando-se áreas de risco por movimentos de massa, como visualizado no Mapa de Suscetibilidade a movimentos de Massa.

- Influência da malha viária: A malha viária influencia na distribuição espacial de diferentes classes de uso do solo no Vale do Ribeira (principalmente bananicultura). Também apresenta relação com a fragmentação, densidade de habitações, agricultura e pastagem (HAWBAKER, et al. 2004).

- Influência das áreas agrícolas: Uma das principais fontes de renda do Vale do Ribeira é a bananicultura. No capítulo 10 (Evolução do uso do solo no Vale do Ribeira de Iguape e Litoral Sul entre 1986, 1999 e 2010) registrou-se que essa classe agrícola, entre (1986 a 2010) apresentou um grande crescimento (440\%). Assim, é um importante agente modificador da paisagem.

- Formação de núcleos residências: Processo de evolução territorial, onde pequenos núcleos urbanos tornaram-se cidades. Estes núcleos cresceram horizontalmente para determinada direção de maneira planejada ou impulsionada por alguma característica física do terreno ou por fator econômico, como a valorização de terras. Assim, torna-se um fator modificador da paisagem. 
- Suscetibilidade a processos erosivos: Os processos de dinâmica superficial são aqueles que modificam a superfície da Terra, produzindo diferentes paisagens conforme a estruturação geológica, climática e o tempo de atuação (Silva, 2002). Diversos agentes podem estar envolvidos na geração do processo (água, vento, gelo e organismos), que são agrupados genericamente como erosão (Infante Jr. \& Fornasari Filho, 1998). Considerando que apenas $32,7 \%$ da área da UGRHI-11 são adequadas à agricultura e que essa tem grande influência na economia da região, será dada prioridade para as terras com menores suscetibilidades à erosão.

- Suscetibilidade a movimentos de massa: Este processo é responsável pela evolução das formas do relevo, que pode causar grandes danos socioeconômicos quando em desequilíbrio (Guidicini \& Nieble, 1984). Tais movimentos envolvem o deslocamento de rocha e/ou solo vertente abaixo (Costa \& Baker, 1984). É um processo relacionado com aspectos naturais, como chuvas intensas e prolongadas, estruturas geológicas, declividades acentuadas, drenagem superficial e subsuperficial, e vegetação. Porém, cabe salientar que há relação dos movimentos de massa e áreas onde existe interferência na natureza para a construção de estradas e habitação. A UGRHI-11 apresenta áreas, tanto urbanas quanto rurais, com altas declividades, em alguns casos com presença de grandes blocos e a cada ano com maior presença de núcleos urbanos nestas áreas de risco. Ou seja, é um fator físico com implicações sociais. Neste agente modificador, será dada prioridade às áreas com menores suscetibilidades a movimentos de massa.

- Vegetação arbórea densa: Neste processo, utilizou-se um agente restritivo da paisagem, a "vegetação arbórea densa", que foi utilizada como um filtro.

\subsection{Calibração do modelo}

A calibração do modelo foi realizada simulando-se o ano 2010, a partir dos mapas de uso e ocupação do solo de 1986 e 1999. O intuito desta calibração foi de estipular quanto de acurácia há no modelo ao comparar o mapa simulado de 2010 com o mapa de uso e ocupação do solo de 2010 produto da classificação supervisionada em cenas do sensor Landsat 5.

Os mapas de uso e ocupação do solo dos anos de 1986 e 1999 (em formato raster, com resolução espacial de 30 metros) foram utilizados como dados de entrada no módulo de Markov. Os arquivos de saída deste módulo são uma matriz de probabilidade de transição, que representa a probabilidade de cada pixel de cada categoria de uso e ocupação do solo 
sofrer mudança para outra categoria; e um grupo de imagens de probabilidades condicionais, que representam as probabilidades de cada pixel da área de estudo estar em cada uma das categorias de uso e ocupação do solo no futuro.

Esta calibração foi realizada no módulo Markov do programa IDRISI Andes (Figura 43).

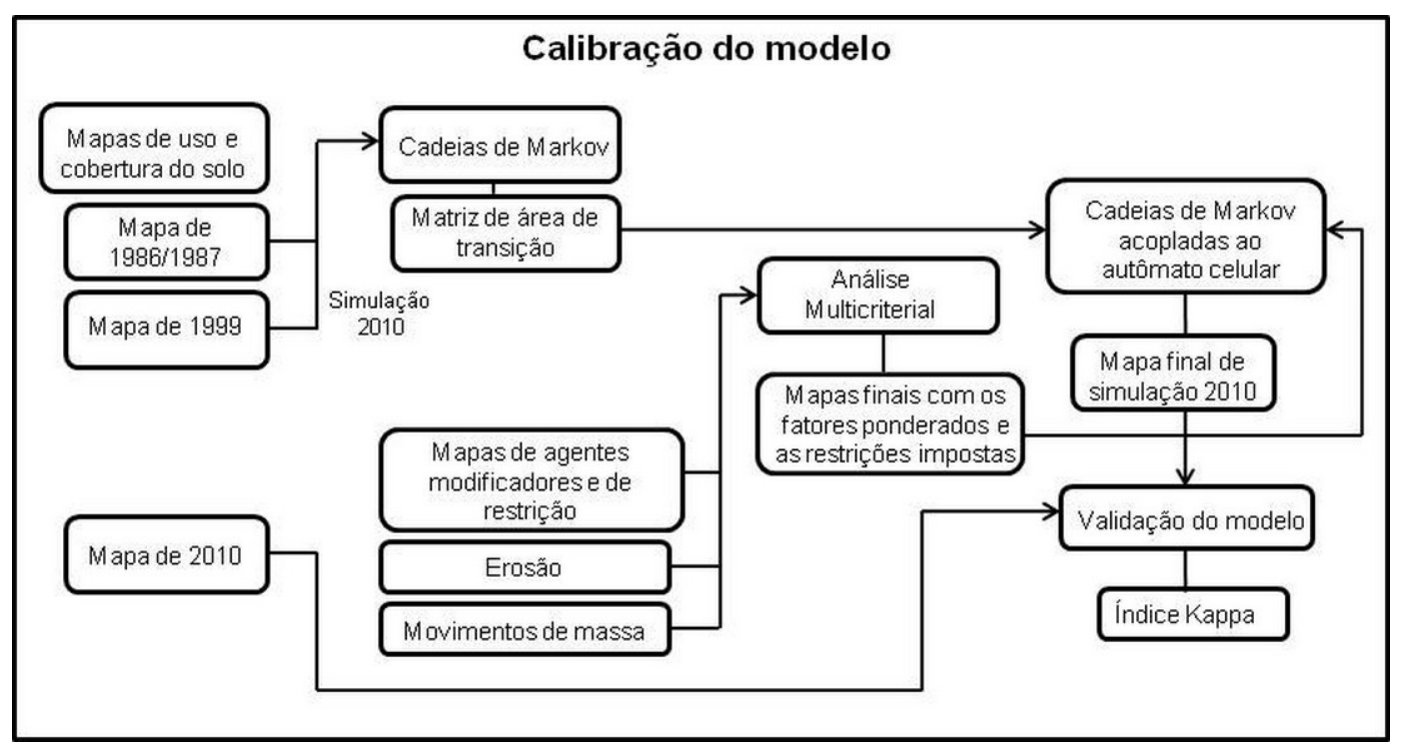

Figura 43. Representação do método de calibração do modelo, baseado em Terra (2010).

Elaborou-se um mapa para cada agente modificador da paisagem selecionado. Através de vários testes, utilizando diferentes tipos de funções e pontos de controle no módulo "Fuzzy".

No Idrisi, o módulo FUZZY é responsável pela padronização dos fatores. Este módulo fornece as opções de padronização dos fatores tanto para uma escala de números reais, zero e um, quanto para uma escala em bytes, zero e 255. Esta última opção é a recomendada para o Idrisi porque o módulo MCE foi projetado para processamentos mais rápidos em bytes (Eastman, 2006). 


\subsubsection{Declividade}

O mapa de declividade foi elaborado no Programa IDRISI (Eastman, 2006). A partir das curvas de nível extraídas das cartas topográficas na escala 1:50.000 do IGC (Instituto Geográfico e Cartográfico) elaborou-se um Modelo Digital de Elevação (MDE) no programa ArcGIS 10 (ESRI, 2010). No IDRISI este MDT foi inserido no módulo "Surface" e, assim, obteve-se o mapa de declividade em percentagem. O mapa de declividade foi reclassificado no módulo "Reclass" para a escala de zero a 255 . Os intervalos utilizados foram baseados no trabalho de Ramalho Filho e Beek (1995) apud Terra (2010). A imagem resultante do reescalonamento e o intervalo utilizado neste processo podem ser visualizados na Figura 44 e Tabela 32, respectivamente.

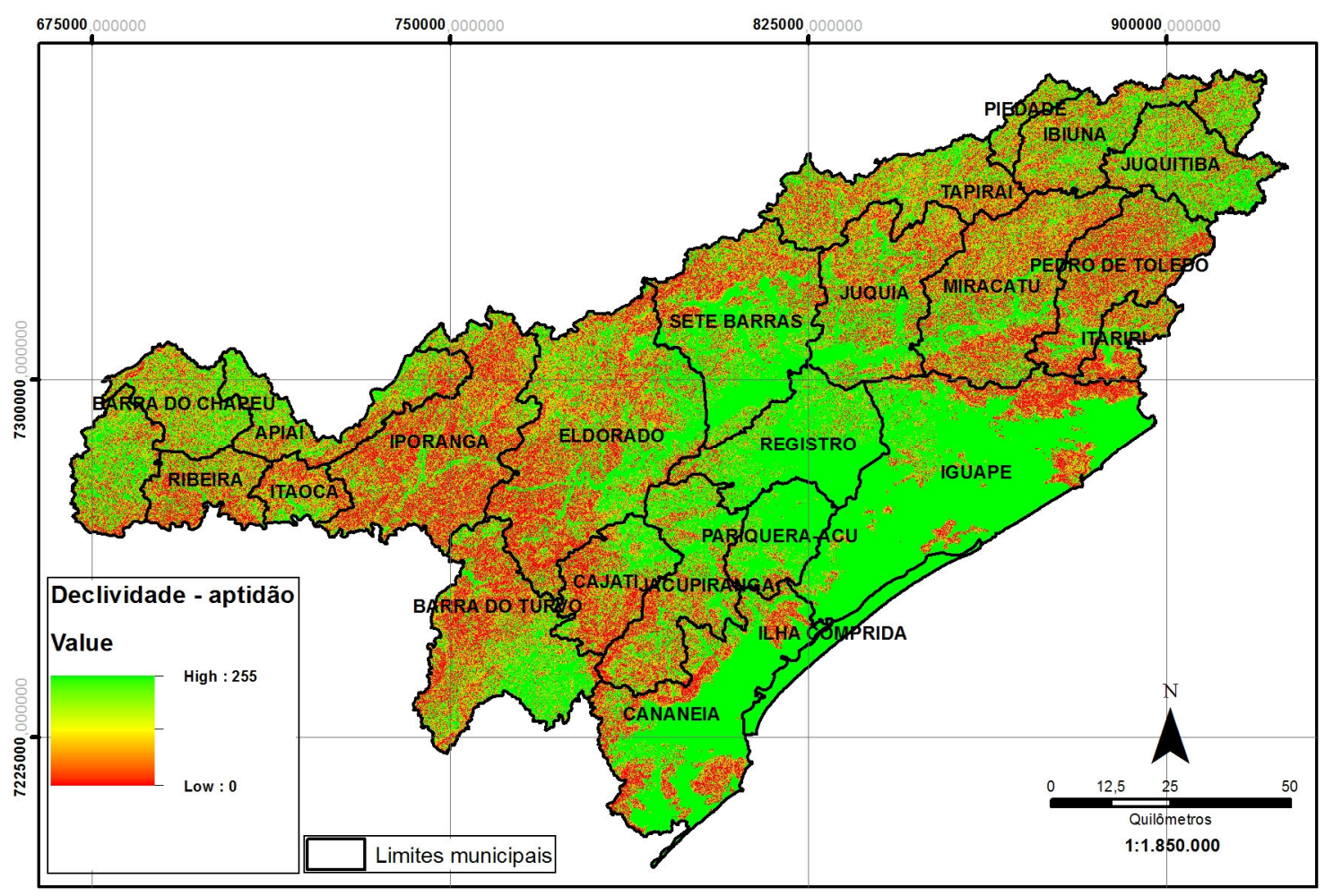

Figura 44. Mapa de adequação do uso do solo terra a partir da declividade. As áreas com valor zero não apresentam influência com agente modificador da paisagem, em contrapartida as áreas com valor 255 apresentam máxima influência como agente modificador. 
Tabela 32. Intervalos de declividade, valores e classes de adequação de uso.

Classes de declividade (em graus) Valores de adequação Classes de adequação

\begin{tabular}{ccc}
\hline a $13 \%$ & 255 & Alta \\
13 a $20 \%$ & 170 & Média \\
20 a $45 \%$ & 85 & Baixa \\
45 a $100 \%$ & 0 & Restrita \\
\hline
\end{tabular}

Fonte: Terra (2010).

\subsubsection{Influência das vias de acesso}

No módulo "Reclass" foi elaborada uma imagem boleana, onde as vias de acesso receberam o valor 1 e as demais classes valor zero. Esta imagem booleana foi inserida no módulo "Distance" para elaboração do mapa de distâncias a partir das as linhas que representam a malha viária. As imagens de saída do módulo "Distance" foram inseridas no módulo "Fuzzy", onde foi estabelecida a função sigmoidal decrescente. Os valores dos pontos de controle são: a)100m e b)200m (Figura 45).

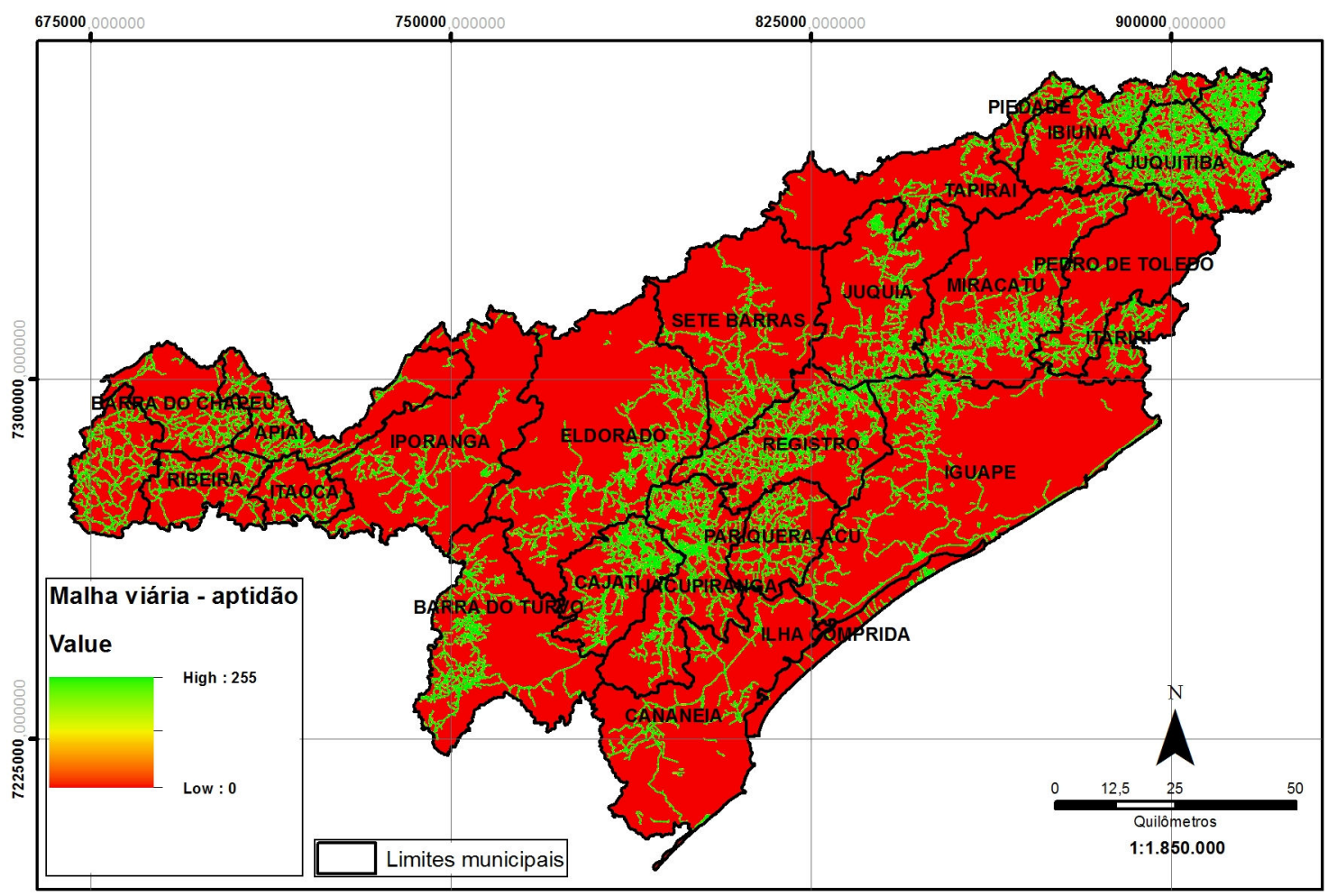

Figura 45. Mapa de adequação do uso do solo terra a partir da malha viária. As áreas com valor zero não apresentam influência com agente modificador da paisagem, em contrapartida as áreas com valor 255 apresentam máxima influência como agente modificador. 


\subsubsection{Influência das áreas agrícolas}

Semelhante ao procedimento executado para a malha viária, as áreas de bananicultura foram reclassificadas com o valor 1 e as demais classes receberam o valor zero. Foi executado o módulo "Distance" e o mapa de saída foi reescalonado no módulo "Fuzzy", onde foi estabelecida função sigmoidal decrescente. Os valores dos pontos de controle são: a)1.000m e b) $1.500 \mathrm{~m}$ (Figura 46).

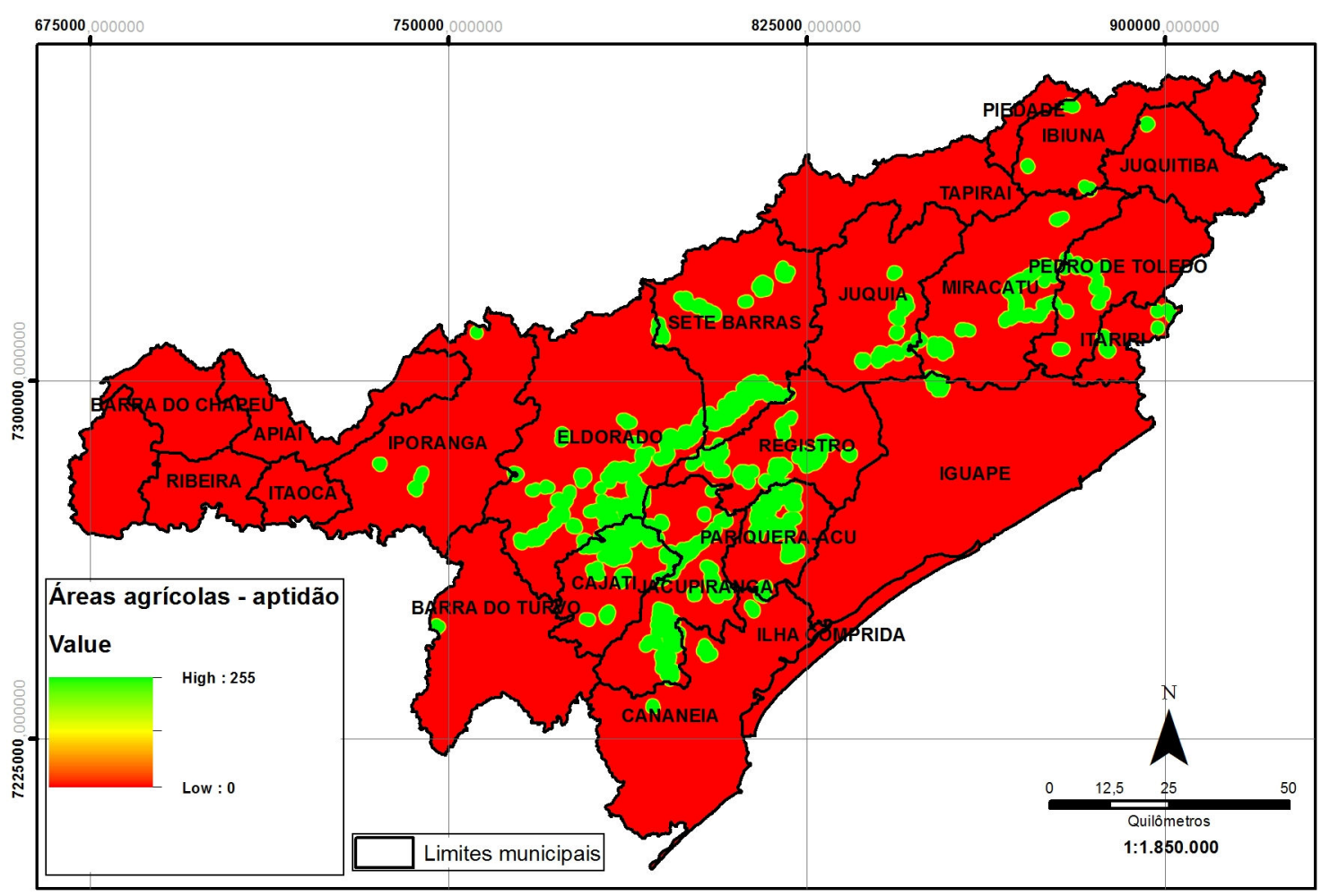

Figura 46. Mapa de adequação do uso do solo terra a partir das áreas agrícolas de 1999. As áreas com valor zero não apresentam influência com agente modificador da paisagem, em contrapartida as áreas com valor 255 apresentam máxima influência como agente modificador.

\subsubsection{Formação de núcleos urbanos}

As áreas urbanas foram reclassificadas com o valor 1 e as demais classes receberam o valor zero. Foi executado o módulo "Distance" e o mapa de saída foi reescalonado no módulo "Fuzzy", onde foi estabelecida função sigmoidal decrescente. Os valores dos pontos de controle são: a)50m e b)100m (Figura 47). 


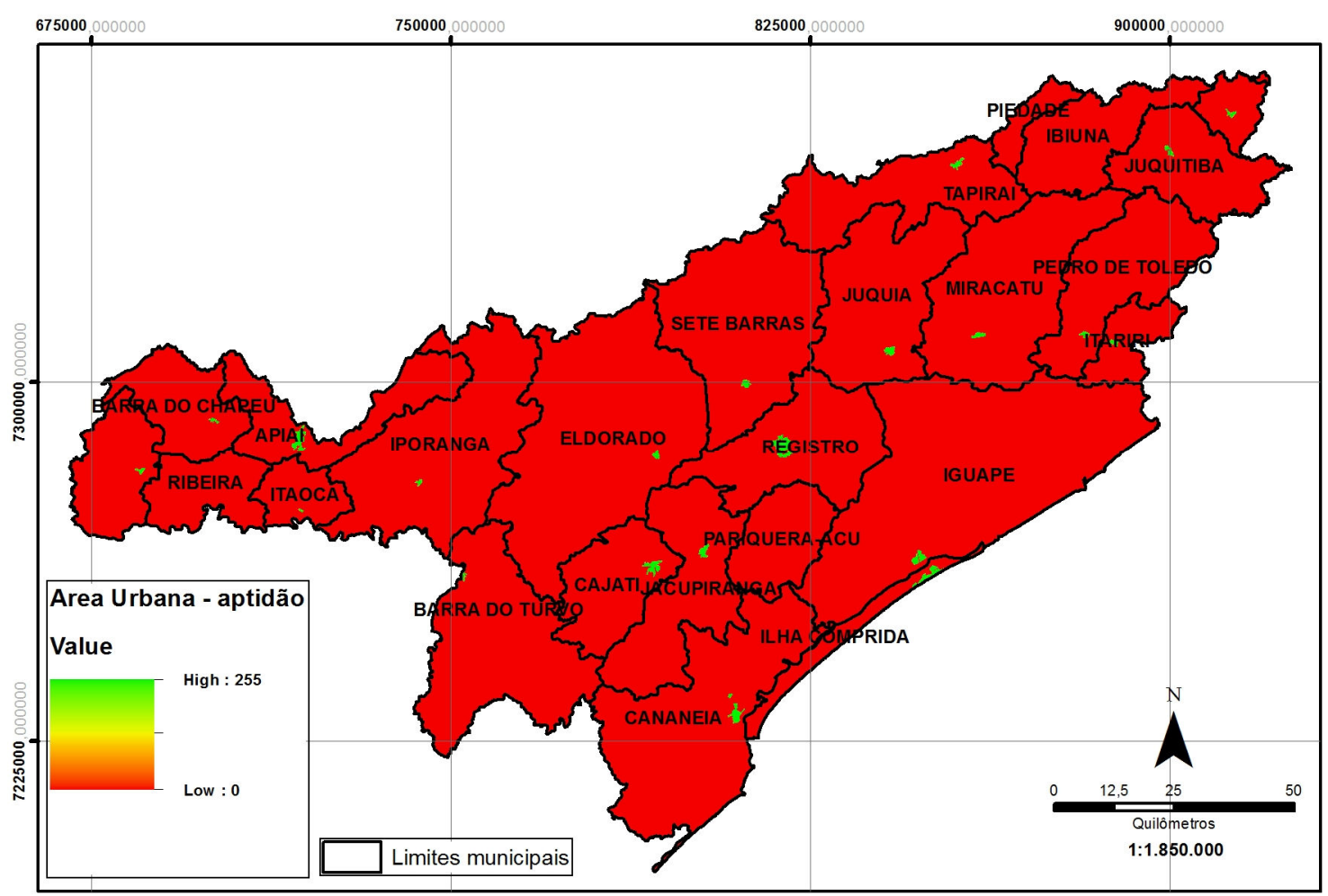

Figura 47. Mapa de adequação do uso do solo terra a partir das áreas urbanas de 1999.

\subsection{5. Áreas suscetiveis a movimentos de massa}

O mapa de suscetibilidade a movimentos de massa apresentado no Capítulo 9 foi utilizado como agente modificador. No módulo "Fuzzy" as áreas que apresentavam menor suscetibilidade a movimentos de massa, receberam o valor máximo de aptidão (255), enquanto as áreas com maior suscetibilidade receberam zero (Figura 48). 


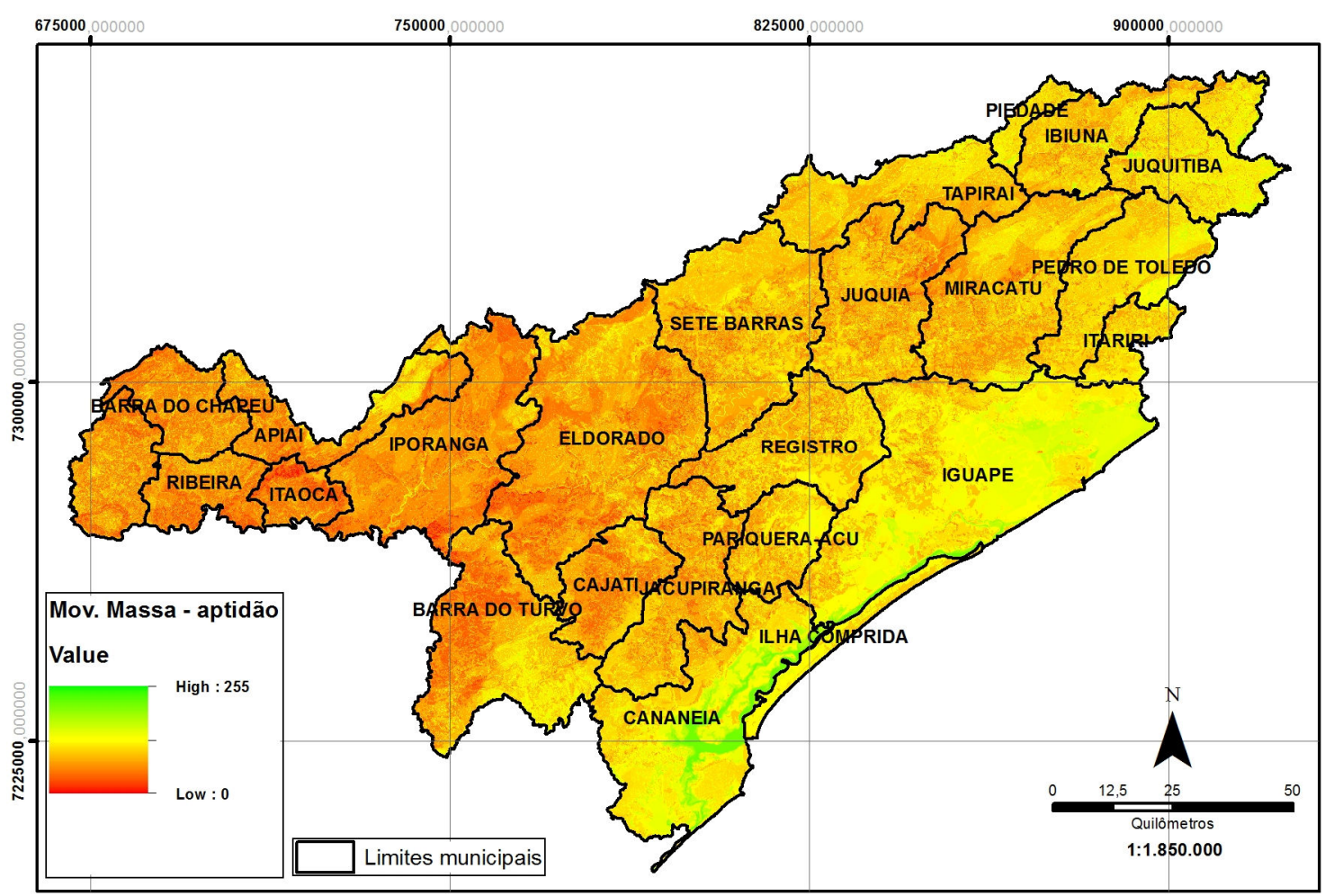

Figura 48. Mapa de adequação do uso do solo terra a partir das áreas suscetíveis a movimentos de massa. As áreas com valor zero não apresentam influência com agente modificador da paisagem, em contrapartida as áreas com valor 255 apresentam máxima influência como agente modificador.

\subsection{6. Áreas suscetíveis à erosão}

O mapa de suscetibilidade a erosão apresentado no Capítulo 9 foi também utilizado como agente modificador. No módulo "Fuzzy" as áreas que apresentavam menores taxas de erosão, receberam o valor máximo de aptidão (255), enquanto as áreas com maior suscetibilidade receberam zero (Figura 49). 


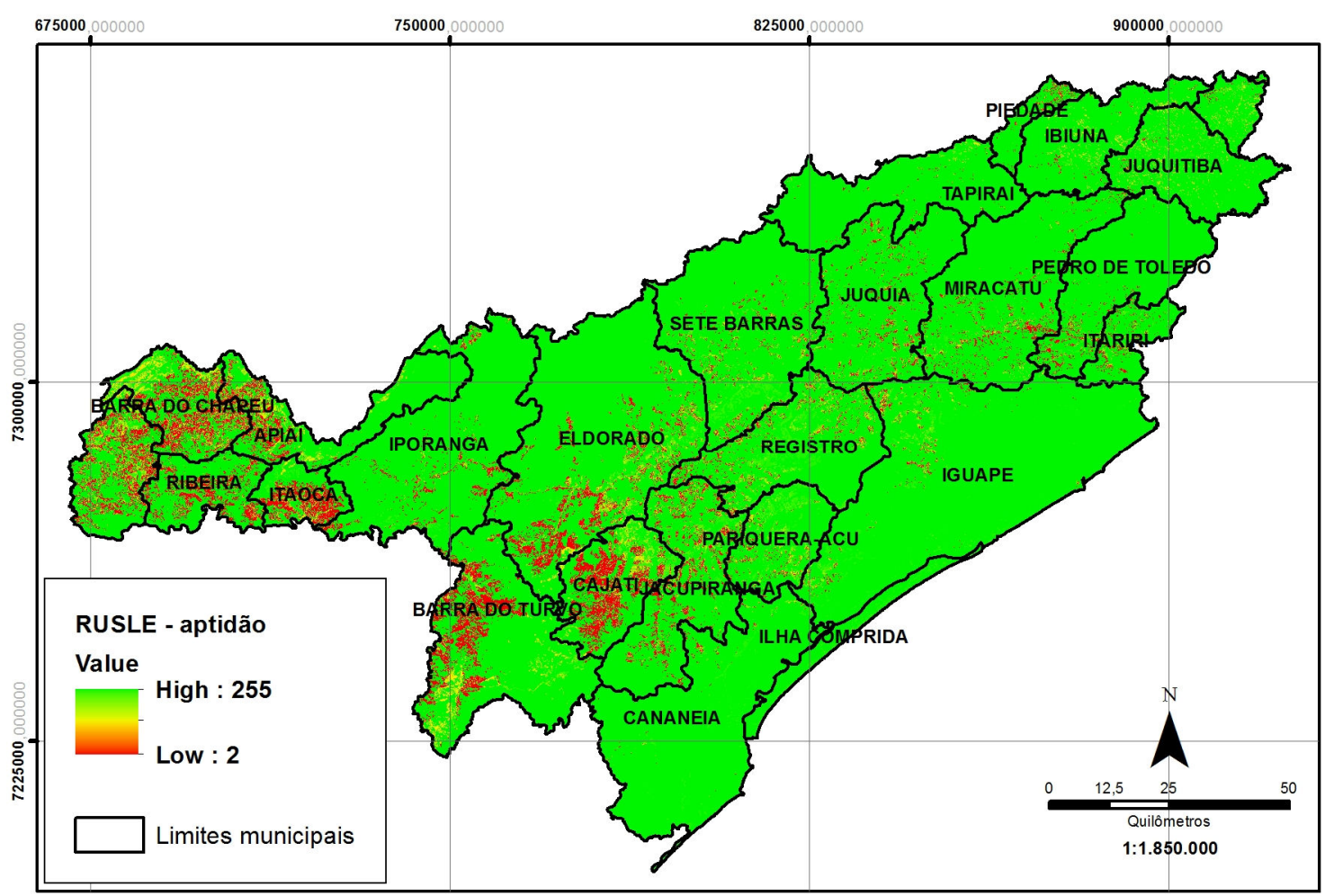

Figura 49. Mapa de adequação do uso do solo terra a partir das áreas suscetíveis a erosão. As áreas com valor zero não apresentam influência com agente modificador da paisagem, em contrapartida as áreas com valor 255 apresentam máxima influência como agente modificador.

\subsubsection{Vegetação arbórea densa como área de restrição}

Foi elaborado um mapa referente à vegetação arbórea densa do ano 1999 para servir de agente restritivo (Figura 50). 


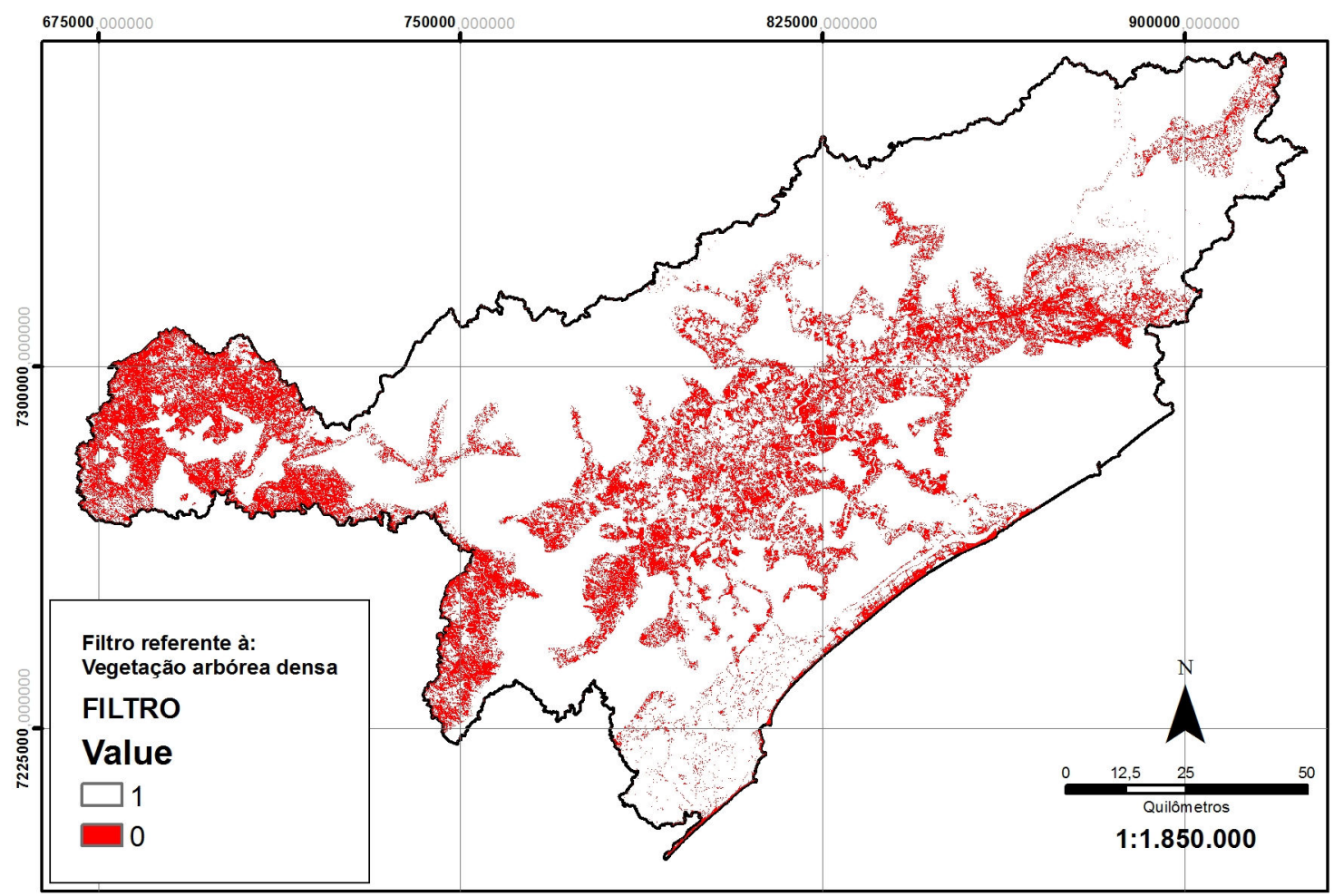

Figura 50. Mapa de restrição do uso do solo terra a partir da vegetação arbórea densa de 1999. As áreas com valor zero não apresentam influência com agente modificador da paisagem, em contrapartida as áreas com valor 255 apresentam máxima influência como agente modificador.

Foram elaborados mapas referentes a cada classe de uso e ocupação do solo, para participarem das Análises Multicritério. As classes e o método utilizado na elaboração de cada mapa podem ser visualizados na Tabela 33.

Tabela 33. Classes de uso e ocupação do solo participantes da Análise Multicritério.

\begin{tabular}{|c|c|c|c|}
\hline \multirow[t]{2}{*}{ Fator } & \multirow[t]{2}{*}{ Função } & \multicolumn{2}{|c|}{$\begin{array}{c}\text { Pontos de controle } \\
\text { (metros) }\end{array}$} \\
\hline & & $\mathbf{a}$ & b \\
\hline Banananicultura & Fuzzy Sigmoidal Decrescente & 1.000 & 1.500 \\
\hline Hidrografia & Fuzzy Sigmoidal Decrescente & 250 & 500 \\
\hline Vegetação arbórea densa & Fuzzy Sigmoidal Decrescente & 1.000 & 2.000 \\
\hline Vegetação de várzea ou campo sujo & Fuzzy Sigmoidal Decrescente & 0 & 10 \\
\hline Solo exposto & Fuzzy Sigmoidal Decrescente & 0 & 10 \\
\hline
\end{tabular}

\subsection{Atribuição de pesos aos agentes modificadores}

Ao módulo "Cellular Automata" do IDRISI Taiga foram inseridos os mapas de cada classe de uso e ocupação do solo, que farão parte do mapa final, que simulará o cenário futuro. Estes mapas das classes de uso e ocupação são resultado de uma Análise Multicriterial 
(Weighted Linear Combination - WLC), onde os agentes modificadores são, primeiramente, multiplicados pelo seu peso. Após essa primeira multiplicação, os resultados de todos os agentes são somados. Os agentes restritivos são aplicados na análise para "zerar" as áreas excluídas. Estes pesos atribuídos aos agentes modificadores na $W L C$ são muito importantes porque determinam como os agentes modificadores (fatores) vão compensar um ao outro. Neste caso, quanto maior o peso do fator, maior influência ele terá no mapa final (Eastman, 2006).

Esse processo de ponderação dos fatores envolvidos na $W L C$ foi executado através do uso da técnica de Principais Componentes. A técnica dos principais componentes é um método de estatística multivariada utilizada para analisar um conjunto de dados visando sua redução, eliminação de sobreposições e atribuir pesos (loadings) mais representativos destes dados a partir de sua combinação linear (Jolliffe, 2002).

Assim, foram realizados procedimentos para cálculo dos pesos dos agentes modificadores da paisagem utilizando o módulo "Principal Components Analysis" do IDRISI Andes (Eastman, 2006). Cada mapa de uso e ocupação do solo teve uma combinação diferente de agentes a fim de encontrar os valores que foram, posteriormente, utilizados na $W L C$, conforme pode ser visualizado nas tabelas referentes aos mapas das classes de área urbana (Tabela 34), hidrografia (Tabela 35), Bananicultura (Tabela 36), vegetação arbórea densa (Tabela 37), vegetação de várzea ou campo sujo (Tabela 38), e solo exposto (Tabela 39).

Tabela 34. Principais Componentes - Área urbana

\begin{tabular}{cc}
\hline Agente modificador & Valor \\
\hline Área urbana & 0,0004 \\
Declividade & 0,0002 \\
Malha viária & 0,9994 \\
\hline
\end{tabular}

Tabela 34. Principais Componentes - Hidrografia

\begin{tabular}{cc}
\hline Agente modificador & Valor \\
\hline Hidrografia & 0,0015 \\
Bananicultura & 0,0002 \\
Declividade & 0,9983 \\
\hline
\end{tabular}


Tabela 36. Principais Componentes - Bananicultura

\begin{tabular}{cc}
\hline Agente modificador & Valor \\
\hline Bananicultura & 0,0000 \\
Declividade & 0,0002 \\
Malha viária & 0,9997 \\
\hline
\end{tabular}

Tabela 37. Principais Componentes - Vegetação arbórea densa

\begin{tabular}{cc}
\hline Agente modificador & Valor \\
\hline Vegetação arbórea Densa & 0,8271 \\
Vegetação de várzea ou campo sujo & 0,1729 \\
\hline
\end{tabular}

Tabela 38. Principais Componentes - Vegetação várzea ou campo sujo

\begin{tabular}{cc}
\hline Agente modificador & Valor \\
\hline Vegetação de várzea ou campo sujo & 0,1096 \\
Hidrografia & 0,0014 \\
Declividade & 0,8890 \\
\hline
\end{tabular}

Tabela 39. Principais Componentes - Solo exposto

\begin{tabular}{cc}
\hline Agente modificador & Valor \\
\hline Solo exposto & 0,03185 \\
Declividade & 0,84748 \\
Áreas suscetíveis a erosão & 0,11654 \\
Área urbana & 0,00407 \\
Malha viária & 0,00006 \\
\hline
\end{tabular}

\subsection{Criação do mapa final com a sobreposição dos agentes modificadores}

Através da aplicação de uma análise multicriterial, no IDRISI, os agentes modificadores foram sobrepostos para elaborar mapas para cada classe de uso e ocupação do solo (resultante do processo de classificação supervisionada). Após o processo de ponderação pelos Principais Componentes, estes agentes foram incorporados como fatores no processo de Combinação Linear Ponderada, onde foram agregados e multiplicados pelos respectivos pesos. Dessa forma, elaboraram-se mapas para cada classe de uso e ocupação do solo, onde cada pixel representa as probabilidades de cada pixel correspondente da área de estudo mudar ou não para outra categoria no tempo estipulado. 
Como já citado no Capítulo 10 (Evolução do uso e ocupação do solo na UGRHI-11), as classes de "vegetação de várzea ou campo sujo" e "solo exposto" sofreram redução de suas áreas entre 1999 e 2010. Porém, nas simulações realizadas nos autômatos celulares, onde os resultados também apresentam redução dessas áreas, essa redução é inferiores às ao mapa real. Chegando ao extremo de obter-se áreas dessas classes $150 \%$ superiores ao mapa real. Assim, forçou-se o sistema a reduzir essas áreas na simulação, utilizando-se um filtro no processo de combinação linear ponderada, onde as classes de "vegetação de várzea ou campo sujo" e "solo exposto" não poderiam aumentar suas áreas sobre as demais classes. Esse filtro foi elaborado utilizando-se uma máscara onde as áreas de "área urbana", hidrografia, "bananicultura" e "vegetação arbórea densa" receberam o valor zero (Figura 51).

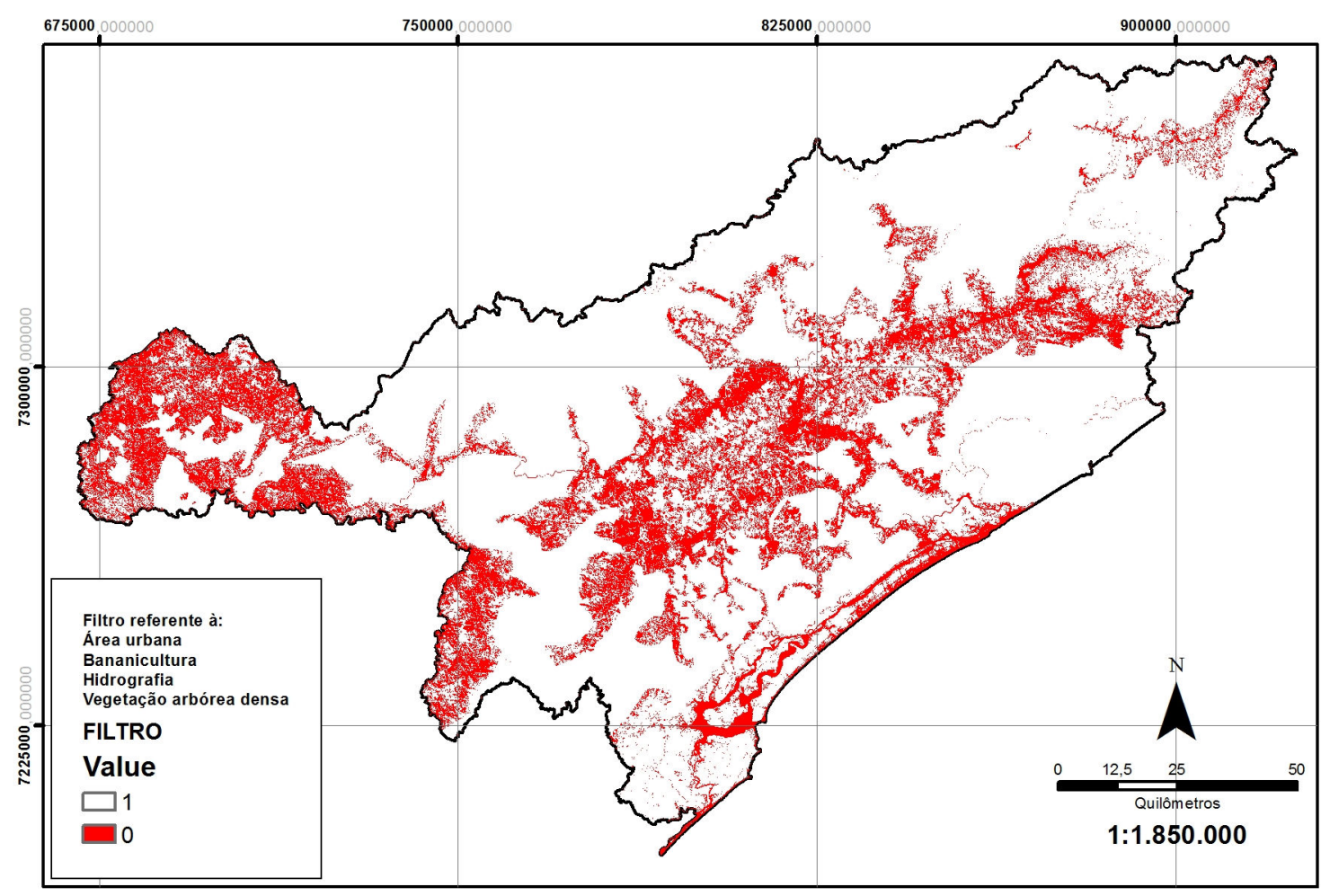

Figura 51. Mapa de restrição às classes de vegetação de várzea ou campo sujo, e solo exposto de 1999. As áreas com valor zero não apresentam influência com agente modificador da paisagem, em contrapartida as áreas com valor 255 apresentam máxima influência como agente modificador.

\subsubsection{Simulação do cenário que represente as classes de uso e ocupação do solo em 2010}

Os mapas das classes de uso e ocupação do solo gerados na análise multicriterial (Combinação Linear Ponderada), foram inseridos no módulo dos autômatos celulares acoplados nas cadeias de Markov, com a matriz de áreas de transição e os mapas de 
probabilidades. Informou-se que a interação é de 11 vezes para o cenário futuro de 11 anos. Foi selecionado o filtro do autômato celular "Standard $5 X 5$ contiguity filter". O resultado deste processo é o mapa do cenário simulado com a distribuição das classes de uso e ocupação do solo, em 2010 (Figura 52). Este mapa foi comparado com outro mapa resultante de classificação supervisionada, referente ao mesmo ano (Figura 53).

Na comparação entre o mapa real e o simulado das classes de uso e ocupação do solo de 2010, as maiores diferenças estão nas classes de "vegetação de várzea ou campo sujo" e "solo exposto" que na simulação apresentaram aumentos de $33 \%$ e $25 \%$ em relação ao mapa real (Tabela 40).

Tabela 40. Áreas das classes de uso e ocupação do solo real e simulado para o ano 2010.

\begin{tabular}{lccc}
\hline \multicolumn{1}{c}{ Classes } & \multicolumn{2}{c}{ Uso e ocupação de 2010 (ha) } & \multirow{2}{*}{ Comparação (\%) } \\
& Real & Simulado & $\uparrow 4$ \\
\hline Área urbana & 7733 & 8042 & $\downarrow 20$ \\
Hidrografia & 35584 & 28340 & $\downarrow 20$ \\
Bananicultura & 32696 & 26133 & $\downarrow 4$ \\
Vegetação arbórea densa & 1405565 & 1349837 & $\uparrow 33$ \\
Vegetação várzea/campo sujo & 154002 & 205455 & $\uparrow 25$ \\
Solo exposto & 67044 & 83485 & \\
\hline
\end{tabular}




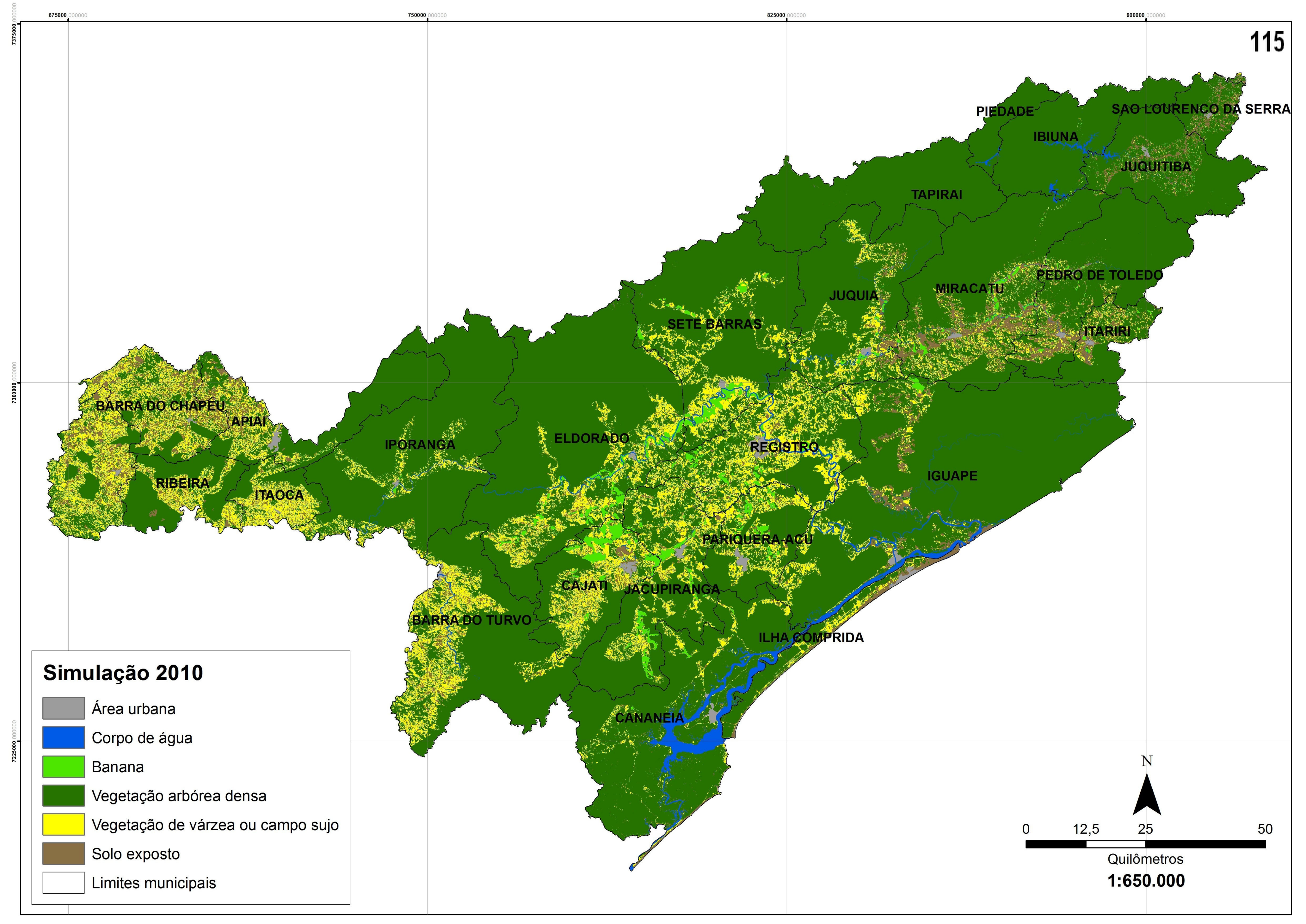




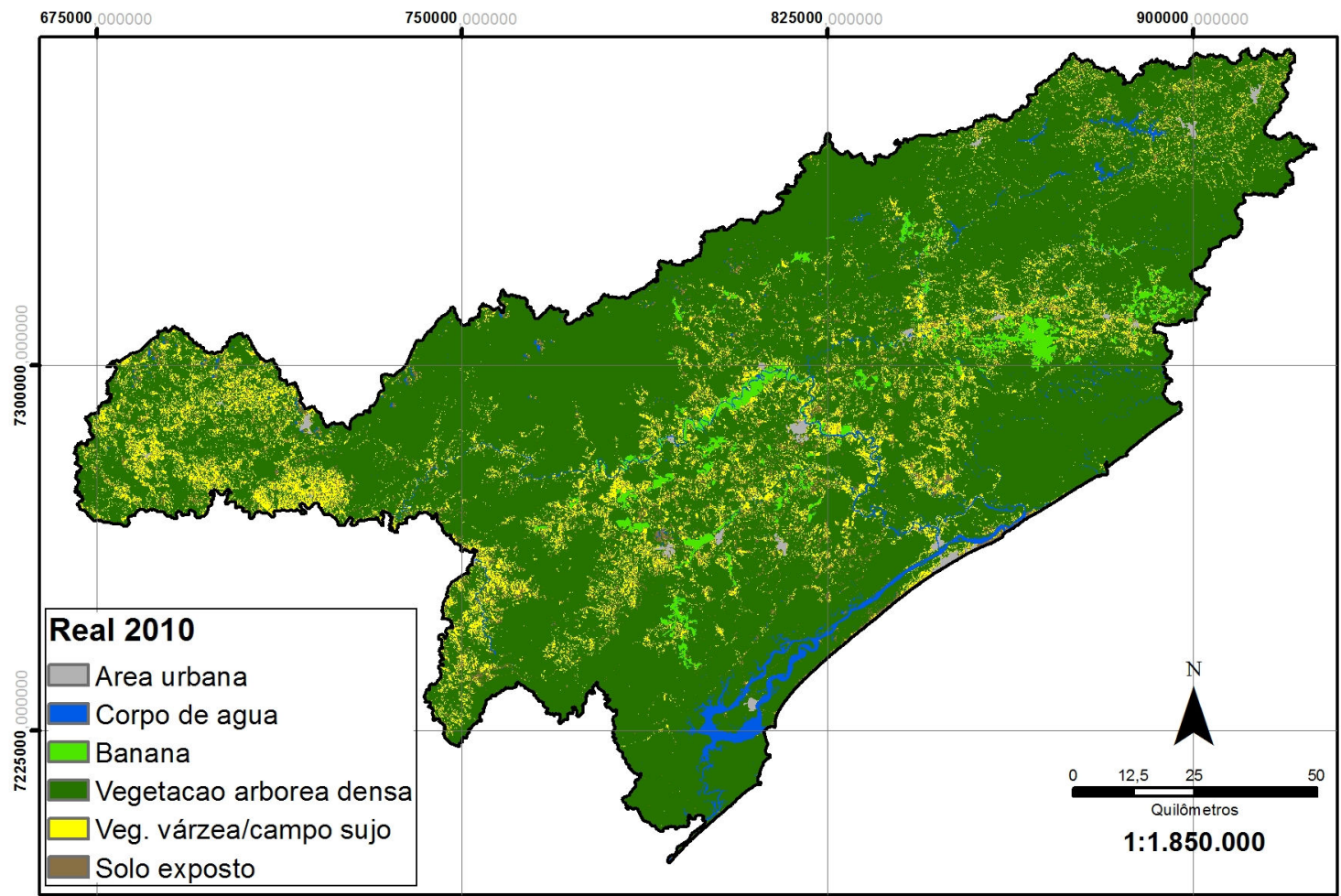

(a)

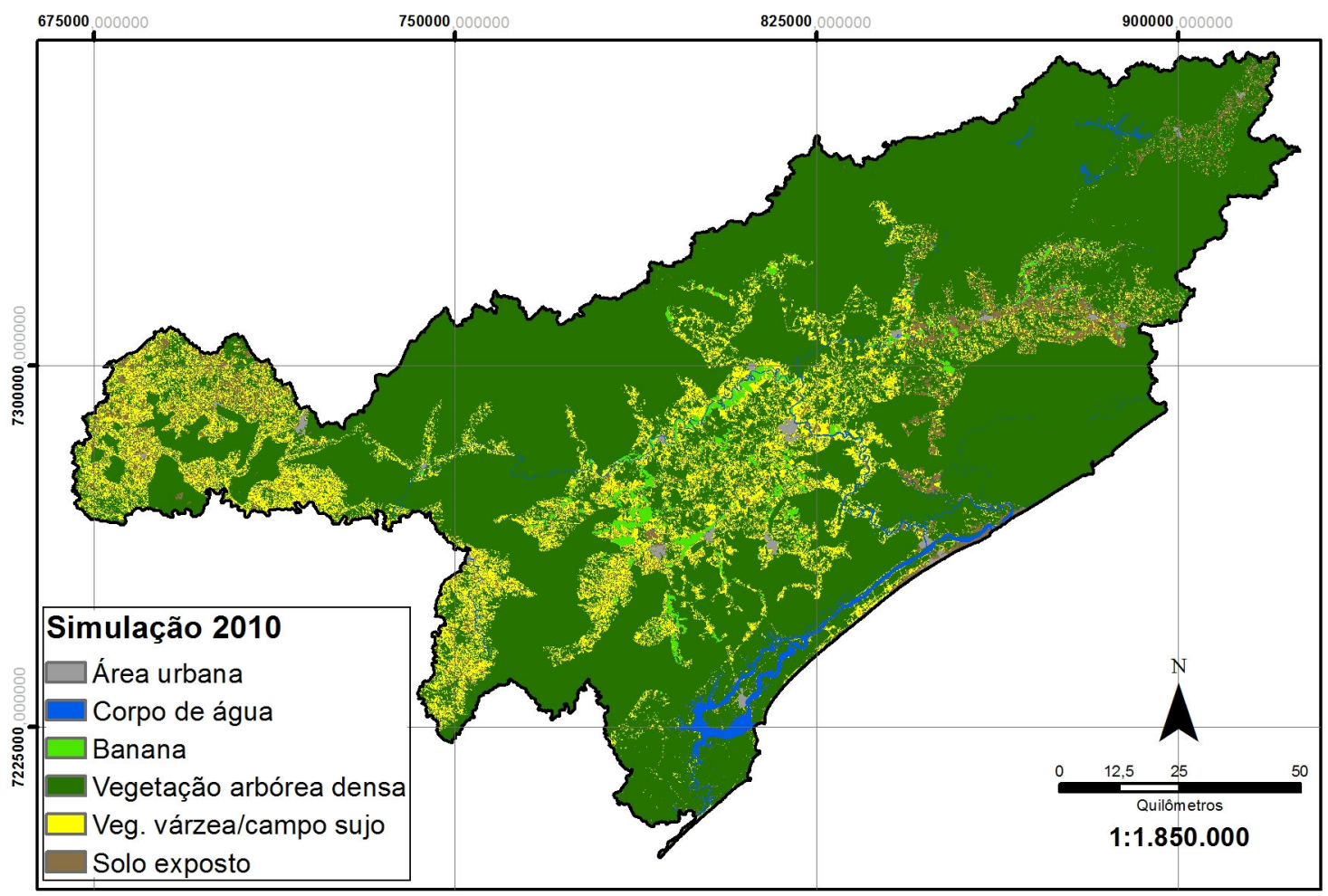

(b)

Figura 53. Mapa real (a) e simulado (b) de uso e ocupação do solo para o ano 2010. 
Ambas as imagens provenientes da classificação e simulação foram comparadas através do índice de concordância Kappa, no módulo "Crosstab” do IDRISI Andes (Eastman, 2006), conforme a equação abaixo, descrita por Landis (1977).

$$
\mathrm{Kappa}=\frac{\left(P_{O}-P_{C}\right)}{\left(1-P_{C}\right)}
$$

Onde:

$P o=$ proporção verdadeira

$P c=$ proporção esperada

Foram utilizadas, aproximadamente, 400 horas de processamento em diversos tipos de simulações mudando os pontos de controle dentro do módulo Fuzzy, para todos os mapas. Assim, o processo foi repitido até atingir o índice de similaridade de 0,4133, que de acordo com Landis (1977) é um índice moderado (Figura 54). Considerando o tamanho da área de estudo $\left(17.067,92 \mathrm{~km}^{2}\right)$, este índice atingido não é o ideal, porém é satisfatório.

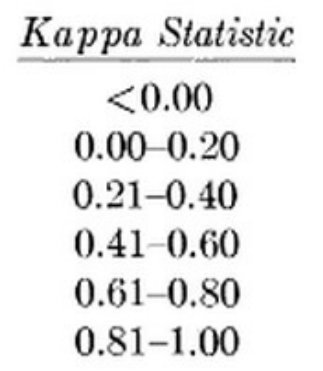

Strength of Agreement
Poor
Slight
Fair
Moderate
Substantial
Almost Perfect

Figura 54. Intervalo de consistência do kappa. Fonte: Landis (1977).

12.3.2. Simulação do cenário que represente as classes de uso e ocupação do solo em 2025

A metodologia empregada para a simulação do cenário de 2010 foi replicada ao intervalo de 15 anos, com base no mapa de 2010 (Figura 55). Assim, foram inseridos os mapas de uso e ocupação do solo de 1999 e 2010 no módulo Markov. Na avaliação multicritério foram inseridos os seis mapas resultantes da combinação dos fatores e restrições referentes a 2010. O resultado é o cenário de 2025 (Figura 56). 


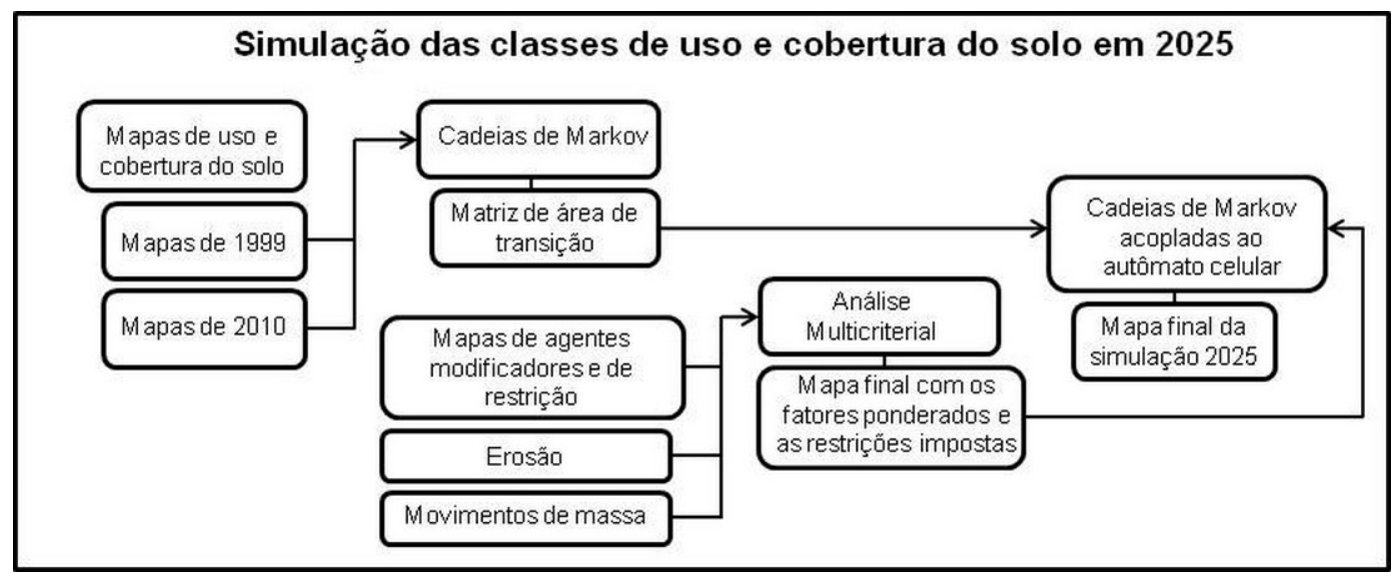

Figura 55. Representação do método de simulação do uso e ocupação do solo para 2025, baseado em Terra (2010). 


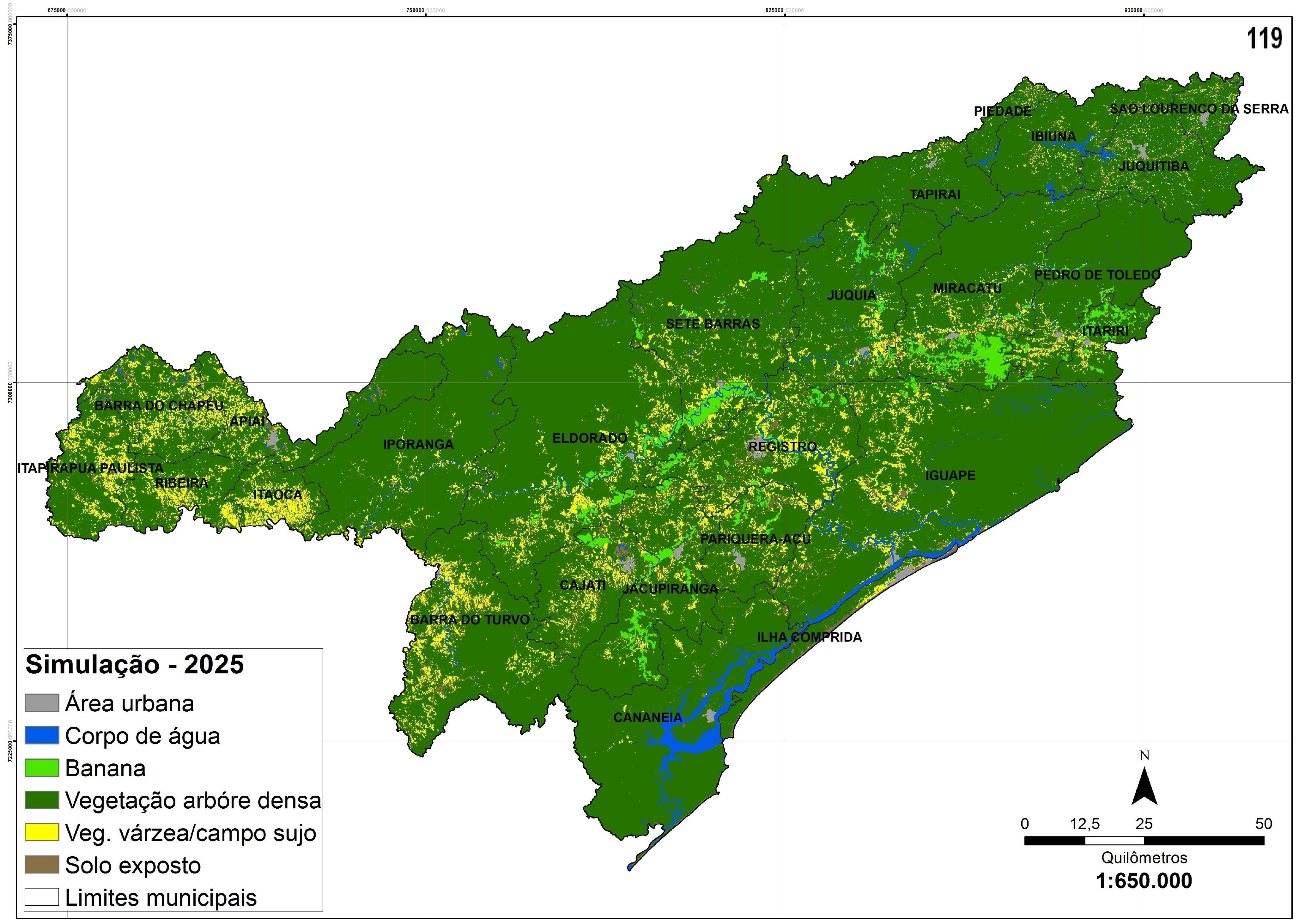


12.3.2.1. Simulação do cenário que representa as classes de uso e ocupação do solo em 2025

Pode-se visualizar na Figura 49 que a hierarquia no tamanho das áreas das classes de uso do solo de 2025 acompanha o ano de 2010, sendo a classe mais expressiva a "vegetação arbórea densa", seguida por "vegetação de várzea ou campo sujo", "solo exposto", "corpo de água", "banana" e "área urbana”, em ordem decrescente (Tabela 41 e Figura 57).

Tabela 41. Áreas das classes de uso e ocupação do solo real e simulado para o ano 2025.

\begin{tabular}{lcc}
\hline \multicolumn{1}{c}{ CLASSES DE OCUPAÇÃO DO SOLO } & \multicolumn{2}{c}{2025} \\
\hline Área urbana & ÁREA $\left(\mathrm{km}^{2}\right)$ & 0,51 \\
Corpo de água & 86 & 2,56 \\
Banana & 435 & 2,16 \\
Vegetação arbórea densa & 368 & 84,5 \\
Vegetação várzea campo sujo & 14.374 & 7,18 \\
Solo exposto & 1.221 & 3,10 \\
\hline
\end{tabular}

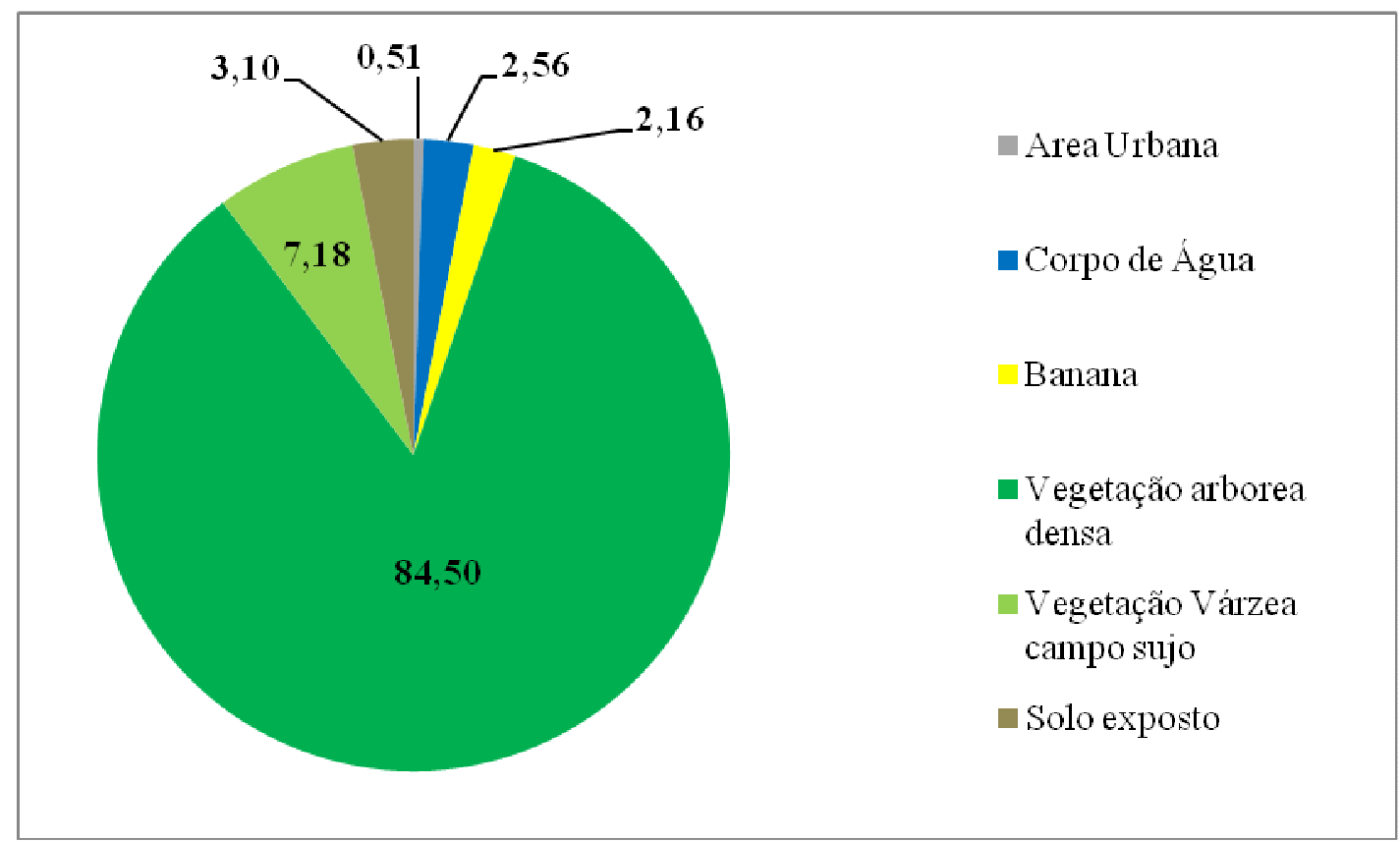

Figura 57. Uso e ocupação do solo da UGRHI-11, em 2025 (em percentagem). 


\subsection{Discussões}

A classe área urbana passará dos $77 \mathrm{~km}^{2}$ (2010) para $86 \mathrm{~km}^{2}$, em 2025 . Ou seja, um crescimento de $12 \%$, que é menor que os $50 \%$ e $22 \%$ referente aos períodos 1986-1999 e 1999-2010, respectivamente (Figura 58).

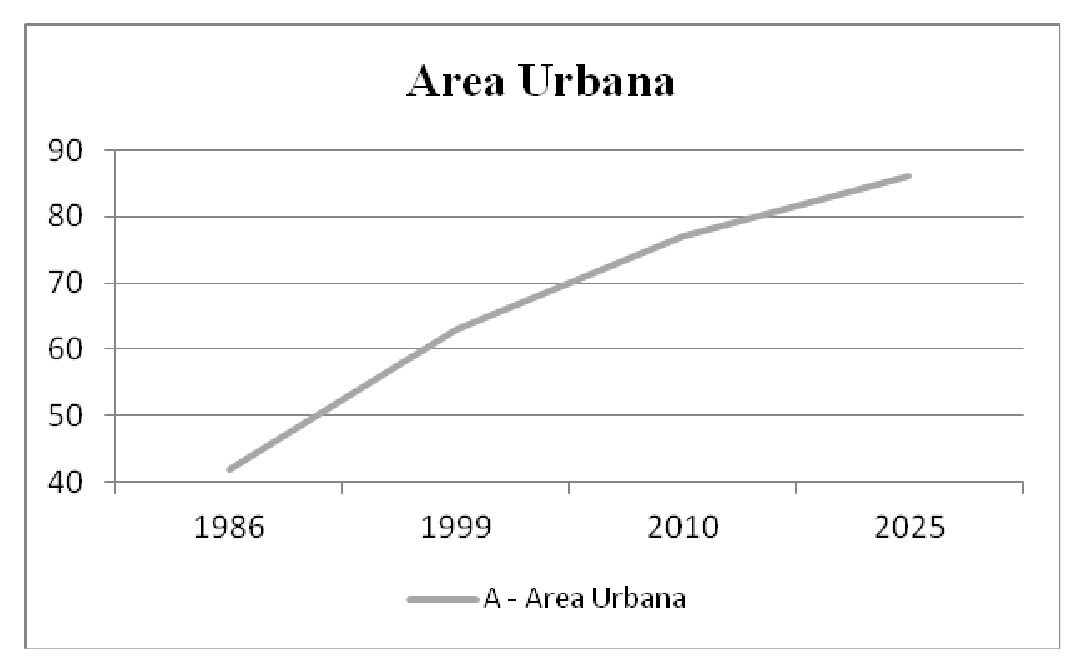

Figura 58. Evolução temporal da área da classe "área urbana" entre 1986 a $2025\left(\mathrm{em} \mathrm{km}^{2}\right)$.

A classe hidrografia, que tem uma boa representação na UGRI-11, uma região rica em recursos hídricos, apresentou algumas variações na sua área no período deste estudo. Esta variação pode ser explicada pelo fato do curso dos rios sofrer mudança ao passar dos anos, e pela vegetação às margens dos rios, em alguns casos mata ciliar, sofrer alterações, o que pode ter confundido a classificação supervisionada. Esta classe passou dos $352 \mathrm{~km}^{2}$ (2010) para $435 \mathrm{~km}^{2}$, em 2025. Ou seja, um crescimento de $23,5 \%$, menor que os $25 \%$ referente ao período 1999-2010. Durante o primeiro período desta análise (1986-1999) houve uma regressão de 12,5\% na área desta classe (Figura 59). 


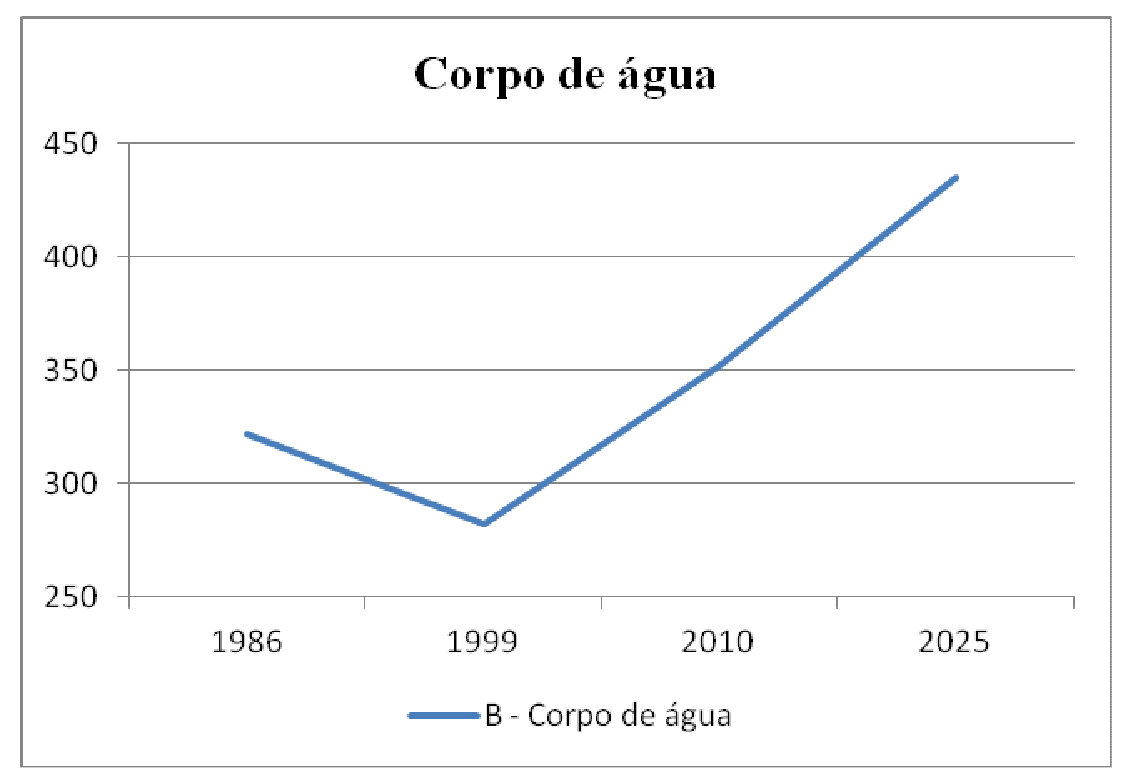

Figura 59. Evolução temporal da área da classe "corpo de água” entre 1986 a $2025\left(\mathrm{em} \mathrm{km}^{2}\right)$.

A Bananicultura, representativa fonte de renda no Vale do Ribeira de Iguape e Litoral Sul, como vem acontecendo desde 1986, recebeu um acréscimo de área no mapa de classes de uso e ocupação do solo, em 2025 . Em 2010 a área era de $237 \mathrm{~km}^{2}$; que passará para $368 \mathrm{~km}^{2}$, em 2025. Um aumento de $12,5 \%$ da área, bastante inferior aos $215 \%$ e $70 \%$ referente aos períodos 1986-1999 e 1999-2010, respectivamente (Figura 60).

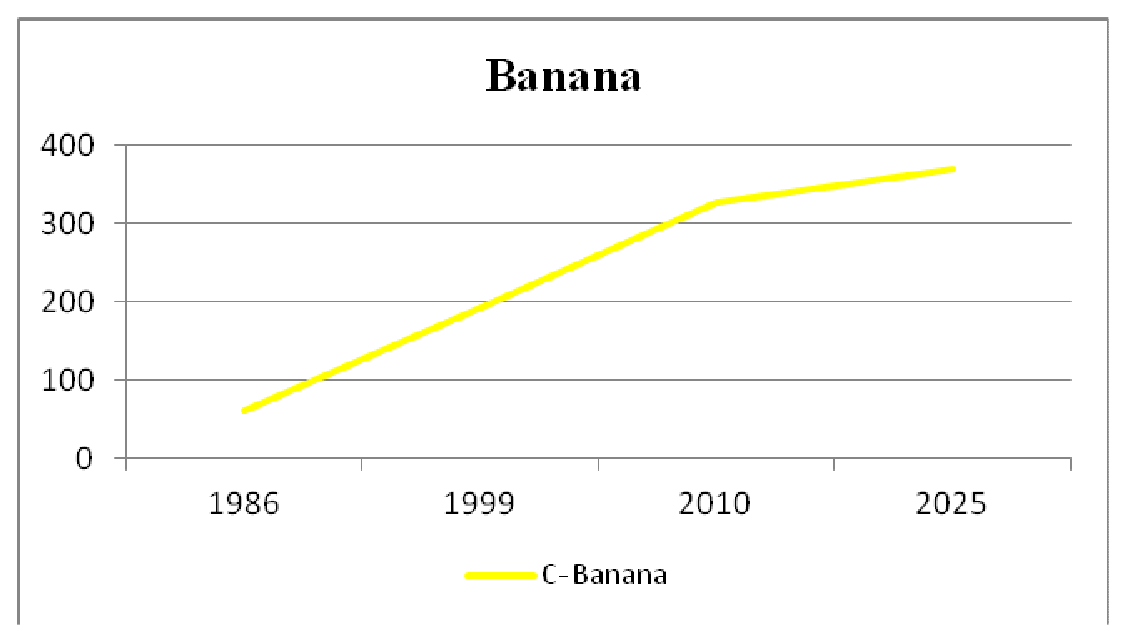

Figura 60. Evolução temporal da área da classe "banana" entre 1986 a $2025\left(\mathrm{em} \mathrm{km}^{2}\right)$. 
A vegetação arbórea densa é a classe mais representativa tanto em todos os mapas extraídos das cenas Landsat, pela classificação supervisionada, quanto na simulação de 2025. Nesta, o mapa simulado apresenta um acréscimo de 2\% de área em relação a 2010 (Figura $61)$.

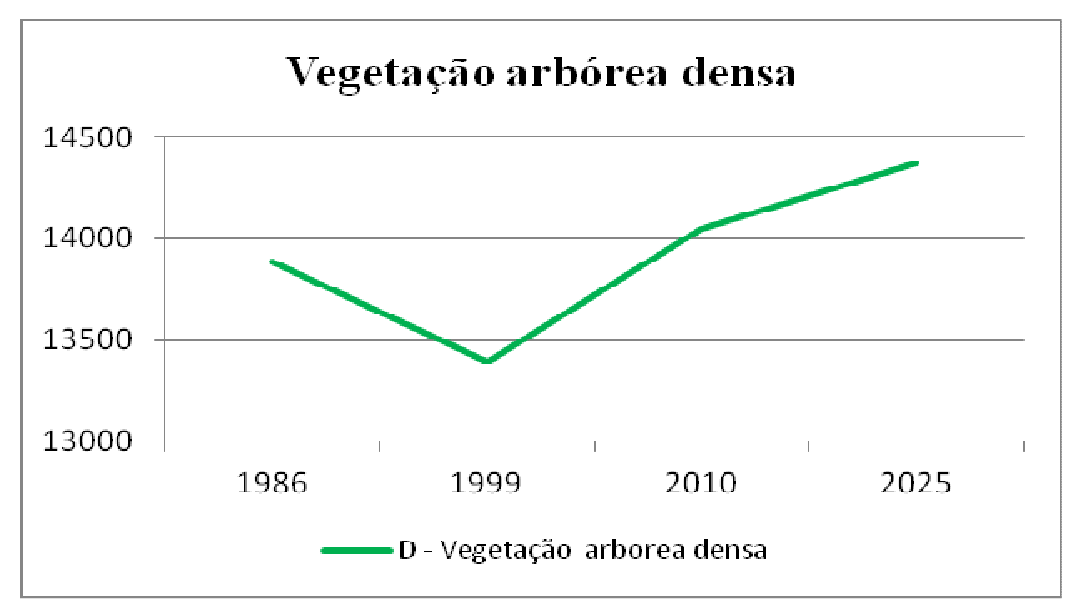

Figura 61. Evolução temporal da área da classe "vegetação arbórea densa" entre 1986 a $2025\left(\mathrm{em} \mathrm{km}^{2}\right)$.

Em todo o período do estudo a classe vegetação de várzea ou campo sujo apresentou redução de área, situação semelhante se repete no mapa simulado para 2025. Em relação a 2010 a simulação apresenta uma redução de 20,5\% de área (Figura 62).

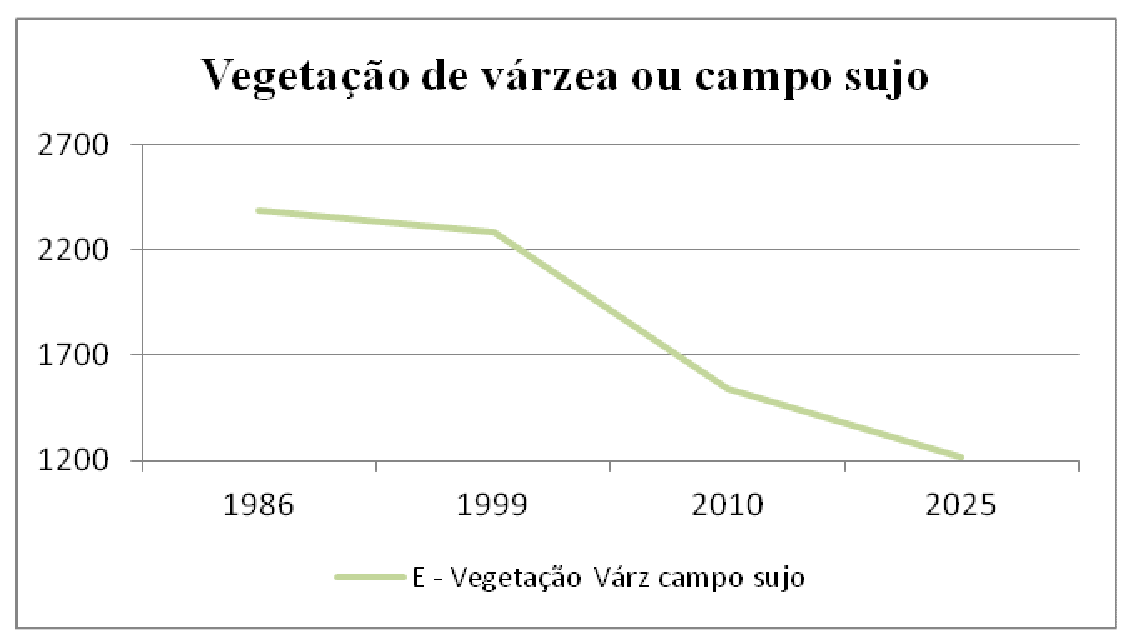

Figura 62. Evolução temporal da área da classe "vegetação de várzea ou campo sujo" entre 1986 a $2025\left(\mathrm{em} \mathrm{km}^{2}\right)$. 
A última classe, solo exposto, apresentou acréscimo de área no primeiro período (1986-1999) de 173\%; redução no segundo período (1999-2010) de 16\%; e, novamente, decréscimo de 21,5\% na simulação de 2025 (Figura 63).

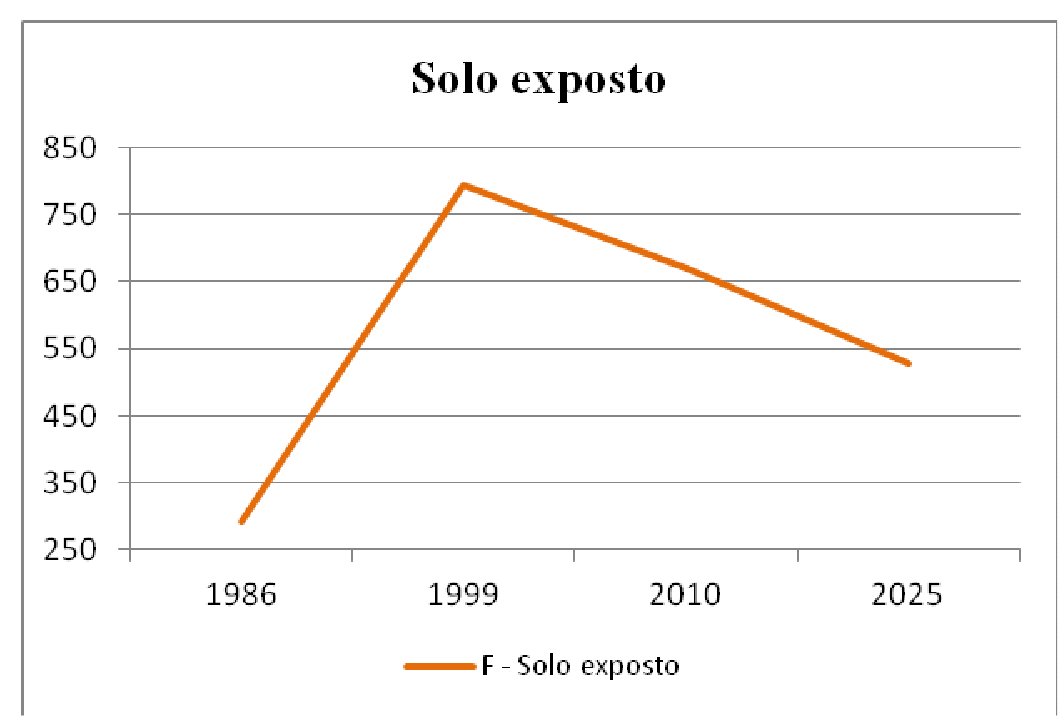

Figura 63. Evolução temporal da área da classe "vegetação de várzea ou campo sujo" entre 1986 a $2025\left(\mathrm{em} \mathrm{km}^{2}\right)$. 


\section{INDICAÇÃO DE CLASSES DE USO E OCUPAÇÃO DO SOLO AFETADAS POR UM POTENCIAL AUMENTO DO NÍVEL DO MAR NO ANO 2025, NO COMPLEXO ESTUARINO LAGUNAR DE IGUAPE- CANANÉIA}

No capítulo 11 foram calculados os níveis máximos atingidos e a área atingida pela máxima preia-mar na região do Complexo Estuarino-Lagunar de Iguape e Cananéia. Os modelos utilizados foram Intergovernmental Panel on Climate Change (IPCC), Ramhstorf e Pfeffer para o ano 2100; e Titus e Narayanan para os anos 2025, 2050 e 2100. Pelo fato do objetivo final deste projeto de tese ser a indicação das classes de uso e ocupação do solo do mapa simulado para 2025, apenas os mapas resultantes do modelo de Titus e Narayanan foram utilizados nesta simulação.

\subsection{Nível do mar em Cananéia (1999)}

De acordo com os registros do marégrafo de Cananéia, disponíveis no site do Permanent Service for Mean Sea Level, o valor médio do nível do mar em Cananéia, em 1999, foi de 1,76 m. A variação máxima diária da maré em Cananéia está entre -0,1 m e 1,3 m. Assim, somando-se a altura média do nível do mar, em 1999, ao valor da máxima preiamar possível, o nível máximo do mar em Cananéia pode ter atingido o valor de 3,06 m, o que, teoricamente, resultaria numa inundação de $452 \mathrm{~km}^{2}$.

\subsection{Sobreposição do limite do CECI à simulação de 2025}

O limite do Complexo Estuarino-Lagunar de Iguape e Cananéia (CECI) foi sobreposto ao mapa da simulação das classes de uso e ocupação do solo da UGRHI-11, em 2025 (Figura 64). Posteriormente, com a utilização da extensão "Extract by Mask” do ArcGIS 10 (ESRI, 2010), o mapa de 2025 foi recortado com o limite do CECI (Figura 65). 


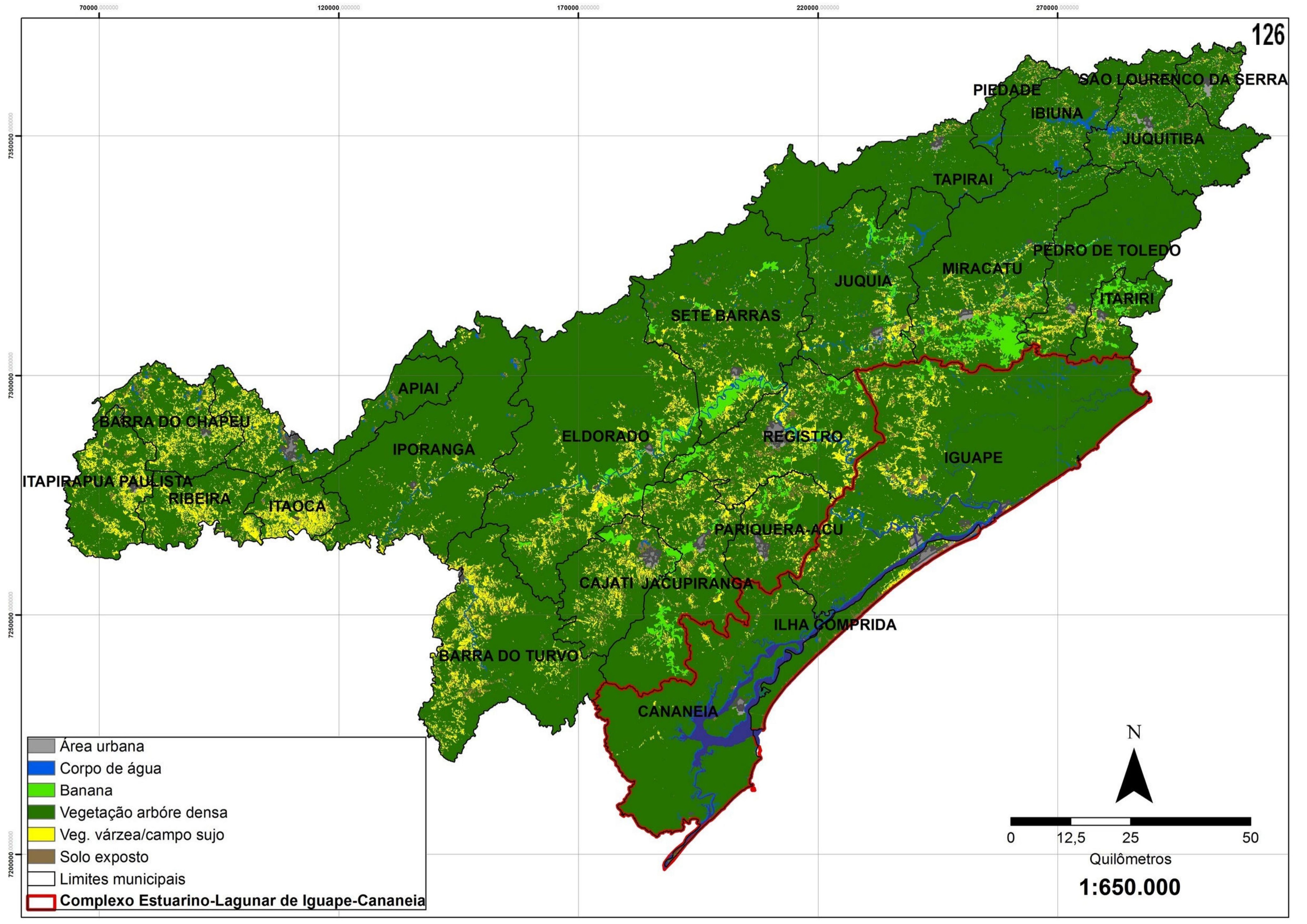




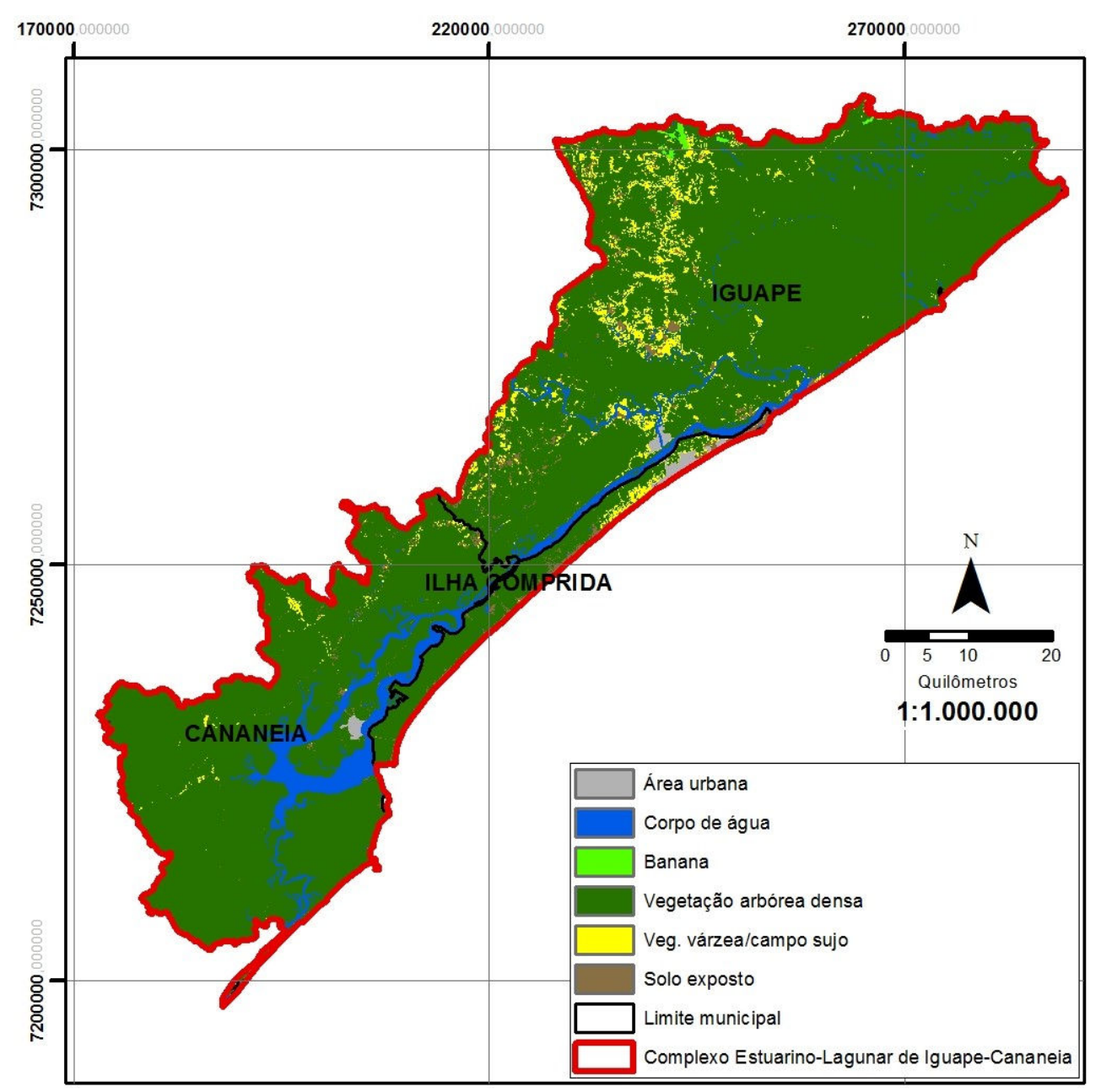

Figura 65. Classes de uso e ocupação do solo do CECI, em 2025.

\subsection{Sobreposição dos resultados de Titus e Narayanan sobre o mapa de 2025}

As áreas atingidas pela máxima preia-mar em 2025, resultantes da equação (Eq. 2) de Titus e Narayanan (1998) foram sobrepostas ao mapa de uso e ocupação do solo simulado para 2025. Estas áreas de inundação dos três cenários calculados para o modelo de Titus e Narayanan foram utilizadas para recortar o mapa de 2025 (Figura 66). Assim foi possível quantificar as áreas atingidas em cada cenário de 2025. 


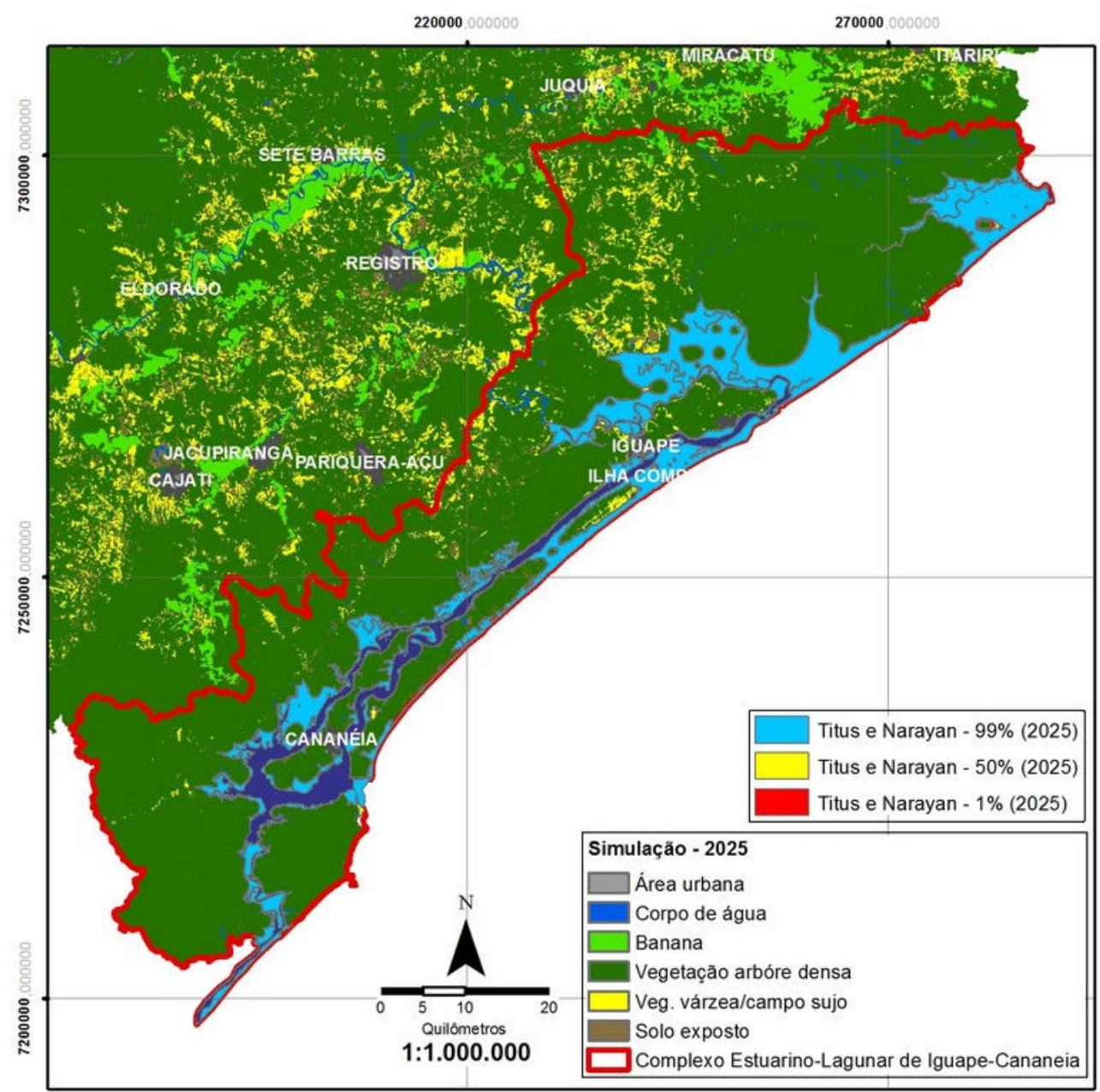

Figura 66. Cenários de Titus e Narayanan sobrepostos ao mapa de uso e ocupação do solo em 2025.

$\mathrm{Na}$ Tabela 42 estão os valores de área e sua percentagem das classes de uso e ocupação do solo que, supostamente, poderiam ser inundadas por um evento de máxima preia-mar no ano 2025. As percentagens (1\%, 50\% e 99\%), segundo Titus e Narayanan (1998), representam a possibilidade de o evento ocorrer. 
Tabela 42. Áreas das classes de uso e ocupação do solo que, supostamente, poderiam ser inundadas por um evento de máxima preia-mar no ano 2025.

\begin{tabular}{lcccccc}
\hline & \multicolumn{2}{c}{$99 \%$} & \multicolumn{2}{c}{$50 \%$} & \multicolumn{2}{c}{$1 \%$} \\
\multicolumn{1}{c}{ CLASSES } & $\mathrm{km}^{2}$ & $(\%)$ & $\mathrm{km}^{2}$ & $(\%)$ & $\mathrm{km}^{2}$ & $(\%)$ \\
\hline Área Urbana & 13,10 & 2,89 & 13,41 & 2,84 & 13,64 & 2,80 \\
Vegetação arbórea densa & 389,15 & 85,91 & 406,25 & 86,07 & 419,84 & 86,21 \\
Vegetação Várz campo sujo & 22,02 & 4,86 & 23,03 & 4,88 & 23,72 & 4,87 \\
Solo exposto & 28,73 & 6,34 & 29,32 & 6,21 & 29,80 & 6,12 \\
Área total inundada & 453 & 100 & 472 & 100 & 487 & 100 \\
\hline
\end{tabular}

Ao comparar as áreas e classes atingidas por um evento de máxima preia-mar em 2025 com os dados referentes a 1999 (Tabela 43), evidencia-se que a área inundada aumenta conforme o tempo evolui. Porém, entre os cenários de Titus e Narayanan a área diminui conforme aumenta a possibilidade do evento ocorrer.

Tabela 43. Classes de uso e ocupação do solo, supostamente, inundadas por um evento de máxima preia-mar em 1999.

\begin{tabular}{lcc}
\hline \multicolumn{1}{c}{ CLASSES } & $\mathrm{km}^{2}$ & $(\%)$ \\
\hline Area Urbana & 8,05 & 1,78 \\
Vegetação arbórea densa & 365,76 & 80,92 \\
Vegetação Várz campo sujo & 34,49 & 7,63 \\
Solo exposto & 43,66 & 9,66 \\
ÁREA TOTAL & 452 & 100 \\
\hline
\end{tabular}

Considerando a total do Complexo Estuarino-Lagunar de Iguape-Cananéia é de $3.414,8 \mathrm{Km}^{2}$, e as áreas atingidas pelas máximas preia-mar registrada em 1999 e prevista para 2025, na Tabela 44 registra-se a percentagem de cada evento em relação à área do CECI.

Tabela 44. Percentagem de área inundada com dados registrados de 1999 e simulados para 2025.

\begin{tabular}{ccc}
\hline Período & $\mathrm{Km}^{2}$ & \% CECI \\
\hline 1999 & 452 & 13,23 \\
$2025(99 \%)$ & 453 & 13,26 \\
$2025(50 \%)$ & 472 & 13,82 \\
$2025(1 \%)$ & 487 & 14,26 \\
Área CECI & 3415 & \\
\hline
\end{tabular}




\subsection{Discussões}

De acordo com os dados da Tabela 42, em 1999, as classes de uso e ocupação do solo do Complexo Estuarino-Lagunar de Iguape-Cananéia atingidas por um evento de máxima preia-mar, em ordem decrescente de tamanho de área são: vegetação arbórea densa; solo exposto; vegetação de várzea ou campo sujo; e área urbana.

$\mathrm{Na}$ simulação do uso e ocupação do solo em 2025, essa hierarquia se repete nos três cenários de Titus e Narayanan (1998). Obviamente, as áreas das classes aumentarão, já que as áreas de inundação, conforme Tabela 41, também recebem acréscimo. As áreas de inundação resultantes dos cenários de Titus e Narayanan (1998) são eventos extremos, pois se considerou nos cálculos a máxima preia-mar. A variação diária do nível médio do mar registrado no marégrafo de Cananéia é de $-0,1 \mathrm{~m}$ a $1,3 \mathrm{~m}$.

As diferenças entre as classes atingidas pela máxima preamar tanto em 1999 quanto em 2025 estão de acordo com a representatividade de cada classe nos mapas de uso e ocupação do solo dos referidos anos. Em 1999, a classe de vegetação arbórea densa representava 84,43\% da área total do Complexo Estuarino-Lagunar de Cananéia e Iguape $\left(3.414 \mathrm{~km}^{2}\right)$ e, esta mesma classe representa $80,92 \%$ do total da área inundada $\left(452 \mathrm{~km}^{2}\right)$, em 1999.

Como pode ser observado nos capítulos 10 e 12, de acordo com a simulação do mapa de uso e ocupação do solo de 2025, a classe de vegetação arbórea densa continuará em expansão, essa classe representará $86,61 \%$ do Complexo Estuarino-Lagunar de Cananéia e Iguape. O cenário mais otimista de Titus e Narayanan (1998) representa uma área de inundação de $453 \mathrm{~km}^{2}$; enquanto o mais pessimista, $487 \mathrm{~km}^{2}$. Considerando o cenário pessimista, 86,21\% da área inundada em 2025 serão compostas por vegetação arbórea densa.

Houve a necessidade de elaboração de um Modelo Digital de Elevação (MDE) da área do Complexo Estuarino-Lagunar de Iguape-Cananéia, pois não havia outro modelo pronto, com o nível de detalhamento necessário. Como citado no capítulo 11, esse MDE foi elaborado a partir do cruzamento de pontos cotados e curvas de nível de cartas topográficas na escala 1:10.000; e uma linha de costa com a atribuição de um metro, delineada em trabalho de campo realizado no município de Ilha Comprida. 


\section{CONCLUSÕES}

A utilização de diferentes tipos de ferramentas das geotecnologias mostrou-se eficaz e mesmo integrando diferentes "frentes" de trabalho, num primeiro momento, independentes: mapeamento de áreas suscetíveis a movimentos de massa e erosão; mapeamento do uso e cobertura do solo da UGRHI-11 e simulação do cenário de 2025; além do cálculo da vulnerabilidade a um potencial aumento do nível do mar (2025, 2050 e 2100). Foi possível agregar todos estes produtos e elaborar o produto final, a quantificação das áreas das classes de uso e ocupação do solo do Complexo Estuarino-Lagunar de Iguape-Cananéia, em 2025.

Em relação ao mapeamento das áreas de risco, pode-se afirmar que processos erosivos e de movimento de massa podem ter causas naturais ou antrópicas. As atividades humanas sobre o terreno devem ser cuidadosamente realizadas para evitar o aumento da instabilidade destas áreas. O processo de ocupação desordenada do solo e aumento da instabilidade do terreno tem sido impulsionado pelo processo migratório da população rural para áreas desocupadas em áreas urbanas, algumas vezes locais em risco geológico ou hidrológico.

A aplicação de um SIG permitiu a integração de dados de diferentes fontes, que, combinados, levou ao desenvolvimento dos mapas de suscetibilidade a erosão e movimento de massa. Os dados de campo mostraram que, apesar da pequena escala (1:250.000), esses mapas fornecem previsões confiáveis na identificação das áreas mais críticas. Porém, estudos mais detalhados são necessários para auxiliar as ações de mitigação e apoiar os planos preventivos das secretarias municipais de defesa civil, planejamento urbano e rural e de zoneamento ecológico e econômico.

No período estudado (1986, 1999 e 2010) as classes de uso e cobertura do solo mais representativas na UGRHI-11 foram: Vegetação arbórea densa, Vegetação de várzea/capoeira/campo antrópico e Solo exposto, que está de acordo com o trabalho desenvolvido por Amaral (2010), que analisou a evolução do uso do solo da área compreendida na Folha "Pariquera-Açu (SG23-V-A-IV-1) entre 1988 e 2008.

Na primeira fase (1986 - 1999) nota-se um decréscimo de $497 \mathrm{Km}^{2}$ na área da classe Vegetação arbórea densa e, inversamente proporcional, um acréscimo de $504 \mathrm{Km}^{2}$ na área da classe de Solo exposto, que supostamente representa o período de abertura de algumas frentes agrícolas na região. Na segunda etapa (1999 - 2010) nota-se uma situação oposta, já que houve um acréscimo de $655 \mathrm{Km}^{2}$ à Vegetação arbórea densa que, provavelmente, por sucessão ecológica ganhou áreas das classes Vegetação de várzea/capoeira/campo antrópico e Solo exposto, que perderam $318 \mathrm{Km}^{2}$ e $143 \mathrm{Km}^{2}$, respectivamente. Possivelmente a classe de 
vegetação arbórea densa também englobou áreas de pastagens e de agricultura de pequeno porte.

Nesta última etapa (1999 - 2010) esta possível sucessão das classes de Vegetação de várzea/capoeira/campo antrópico e Solo exposto para Vegetação arbórea densa é explicada por Amaral (2010) não como resultado do avanço da fiscalização e/ou conservação destas áreas, mas pelo grande êxodo rural ocorrido nesta segunda fase deste estudo.

A partir do cenário simulado para o uso e ocupação do solo em 2025, caso a tendência estudada entre 1986 e 2010 não sofra alterações, o Vale do Ribeira do Iguape e Litoral Sul do Estado de São Paulo continuará sendo uma região com grande área de vegetação arbórea densa, classe que representará $84,5 \%$ do total de área. A bananicultura, forte fonte de renda da região, continuará em grande expansão, sua área será seis vezes maior que em 1986. Esse crescimento da cultura da banana e da área de solo exposto, provavelmente desencadeado por novas frentes agrícolas, será em direção às áreas de vegetação de várzea ou campo sujo, que perderá $36 \%$ de área.

Através dos cuidados básicos necessários ao trabalhar com geotecnologias, como unificar o sistema de coordenadas, foi possível agregar todos os produtos dos capítulos 9, 10, 11 e 12 para concluir esta tese com o Capítulo 13, "Classes de uso e ocupação do solo atingidas por um potencial aumento do nível do mar em 2025”. De acordo com a simulação do mapa final, a classe de vegetação arbórea densa representará $86,61 \%$ do Complexo Estuarino-Lagunar de Cananéia e Iguape e, no cenário mais pessimista de Titus e Narayanan (1998), 86,21\% da área inundada em 2025 serão compostas por vegetação arbórea densa. Em 1999, 80,92\% da área inundada estavam compostas por vegetação arbórea densa. Assim, conclui-se que essa expansão de área da vegetação arbórea densa, em 2025, também ocorrerá no sentido da zona litorânea. Em relação às áreas urbanas, o município de Ilha Comprida poderá ser o mais atingido, pois praticamente toda a área urbana seria coberta pelo mar num evento de máxima preamar, em 2025. As áreas urbanas de Cananéia e Iguape não sofreriam tanta influência da subida da maré.

Como toda previsão, neste estudo há erros que devem ser considerados. Porém, espera-se que os representantes municipais, principalmente dos municípios inseridos no Complexo Estuarino-Lagunar de Iguape-Cananéia, caso ainda não estejam o fazendo, passem a estudar para planejar o crescimento horizontal das áreas urbanas, levando em consideração a provável perda de superfícies urbanizáveis devido à subida do nível do oceano. 


\section{REFERÊNCIAS BIBLIOGRÁFICAS}

AMARAL, C. H. (2010) Evolução do uso do solo e a suscetibilidade natural à erosão das áreas de preservação permanente da folha "Pariquera-Açu"(1:50.000, SG.23-V-A-IV-1), Vale do Ribeira, SP. Dissertação de mestrado. Instituto de Geociências da Universidade de São Paulo. 187 p.

ALMEIDA, F.F.M. de - 1964 - Fundamentos geológicos do relevo paulista. In: Geologia do Estado de São Paulo, Bol. IGG (41):167-263, São Paulo.

ANGONESE, J. G., DELGADO, M. G.; SENDRA, J. B. (2010): Simulación de crecimiento urbano mediante evaluación multicriterio y TIG en el Gran San Miguel de Tucumán (Argentina). En: Ojeda, J., Pita, M.F. y Vallejo, I. (Eds.), Tecnologías de la Información Geográfica: La Información Geográfica al servicio de los ciudadanos. Secretariado de Publicaciones de la Universidad de Sevilla. Sevilla. Pp. 873-888. ISBN: 978-84-4721294-1.

ANTROP, M. (2004): Landscape change and the urbanization process in Europe. Landscape and Urban Planning, ${ }^{\circ}$ 67, p. $9-26$.

AUGUSTO, O. F. (1994): Carta de riscos de escorregamentos: uma proposta metodológica e sua aplicação no município de Ilha Bela, SP. Dissertação (Mestrado) - Engenharia dos solos, Escola Politécnica, Universidade de São Paulo, São Paulo.

BARBOSA, Z. N. T, OLIVEIRA, W. N. O, ALVES, P. R. (2011): Uso de geotecnologias para mapeamento de áreas de riscos. Estudo de caso: Angra dos Reis - RJ. Proceedings of the 15th Brazilian Symposium on Remote Sensing, Curitiba, PR, Brazil, 30th April to 5th May 2011, INPE p. 4940.

BARTH, M.C, TITUS, J.G. (Ed).Greenhouse effect and sea level rise. Van Nostrand Reinhold, New York, 1984.

BECKER, B. K.; EGLER, C. A. G. (1996): Detalhamento da metodologia para execução do ZEE pelos Estados da Amâzonia Legal. Rio de Janeiro, LAGET/UFRJ/SAE-PR. p. 40.

BERTONI, J.; LOMBARDI NETO, F. (1990): Conservação do solo. São Paulo, Ícone, 353p.

BIGARELLA, J. J. (2003): Estrutura e origem das paisagens tropicais e subtropicais. Florianópolis: UFSC.

BRASIL (2013):. Decreto n. 89.817, de 20 de junho de 1984. Estabelece as Instruções Reguladoras das Normas Técnicas da Cartografia Nacional. Acessado em: 31 de janeiro de 2013. Available at: http://www.planalto.gov.br/ccivil_03/decreto/19801989/D89817.htm 
CAIXA ECONÔMICA FEDERAL. (2011): Dados retirado do site da Caixa Econômica Federal em 28 de janeiro de 2011. Disponível em: http://www.caixa.gov.br/.

CAMPANHA, G. A. da C.; GIMENEZ FILHO, A.; BISTRICHI, C.A. (1995): Geologia da Folha Itararé em 1:250 000. In:: SIMP. GEOL. SUDESTE, 4, Águas de São Pedro, 1995. Águas de São Pedro, SBG, p. 111.

CAMPANHA, G. A. C (2007): Cap. 2.2.1 Geologia. In: CBH-RB. Comitê de Bacia Hidrográfica do Ribeira de Iguape e Litoral Sul. 2008. Relatório de Situação dos Recursos Hídricos da UGRHI-11. Available at: http://www.sigrb.com.br. Accessed on 1st June 2010.

CARrERO, R., NAVAS, F., MALVÁREZ, G.; CÁCERES, F. (2010): Aplicabilidad de las TIG en la generación de escenarios de futuro para una gestión integrada de las zonas costeras. En: Ojeda, J., Pita, M.F. y Vallejo, I. (Eds.), Tecnologías de la Información Geográfica: La Información Geográfica al servicio de los ciudadanos. Secretariado de Publicaciones de la Universidad de Sevilla. Sevilla. Pp. 716-727. ISBN: 978-84-4721294-1.

CBH-RB (2010): Comitê de Bacia Hidrográfica do Ribeira de Iguape e Litoral Sul. 2008. Relatório de Situação dos Recursos Hídricos da UGRHI-11. Available at: http://www.sigrb.com.br. Accessed on 3rd June 2010.

CBH-RB (2010): Comitê de Bacia Hidrográfica do Ribeira de Iguape e Litoral Sul. 2009. Relatório de Situação dos Recursos Hídricos da UGRHI-11. Available at: http://www.sigrb.com.br. Accessed on 3rd June 2010.

CECÍliO, R. A., RODRIGUEZ, R. G., BAENA, L. G. N., OLIVEIRA, F. G., PRUSKI, F. F (2009): Aplicação dos modelos RUSLE e WEPP para a estimativa da erosão hídrica em microbacia hidrográfica de Viçosa (MG). Revista Verde de Agroecologia $e$ Desenvolvimento Sustentável, Mossoró, v.4, n.2, p.39-45.

CLAVERO, I., SANTOS, M., NAVARRO, R., GUERRERO, J.J., CÁCERES, F. MOREIRA, J.M. (2010): Implementación de un sistema de escenarios futuros sobre el mapa de usos de suelo de Andalucía. En: Ojeda, J., Pita, M.F. y Vallejo, I. (Eds.), Tecnologías de la Información Geográfica: La Información Geográfica al servicio de los ciudadanos. Secretariado de Publicaciones de la Universidad de Sevilla. Sevilla. Pp. 759-776. ISBN: 978-84-472-1294-1. 
CREPANI, E., MEDEIROS J. S., AZEVEDO, L. G. D., HERNANDEZ, F. P., FLORENZANO, T. G., DUARTE, V. (1996): Curso de sensoriamento remoto aplicado ao zoneamento ecológico-econômico. São José dos Campos: INPE. p 25.

CREPANI, E., MEDEIROS, J. S., HERNANDEZ, F. P., FLORENZANO, T. G., DUARTE, V., BARBOSA, C. C. F. (2001): Sensoriamento Remoto e Geoprocessamento aplicados ao Zoneamento Ecológico-Econômico e ao Ordenamento Territorial. São José dos Campos: INPE. p 103.

COMITÊ DE BACIA HIDROGRÁFICA DO RIBEIRA DE IGUAPE E LITORAL SUL. Relatório de Situação dos Recursos Hídricos da UGRHI-11. (2008): Disponível em: < http://geolig.igc.usp.br/geoproc/rs_ugrhi_rb/index.php> Acesso em 15 de abril de 2008b.

COORDENADORIA DE PLANEJAMENTO AMBIENTAL - SECRETARIA DO MEIO AMBIENTE - GOVERNO DO ESTADO DE SÃO PAULO. Complexo Estuarino Cananéia-Iguape. Acessado em 15 de fevereiro de 2013. Disponível em: http://www.ambiente.sp.gov.br/wp/cpla/complexo-estuarino-cananeia-iguape/.

COSTA, J. E.; BAKER, V. R. (2002): Surficial Geology. New York. John Wiley. 498p. 1984. da Silva, A. C. N. Geoprocessamento e sensoriamento remoto como apoio ao planejamento territorial do município de Iporanga, SP. Dissertação (mestrado) Instituto de Geociências, Universidade de São Paulo, São Paulo.

Decreto $n^{\circ} 89.817$ de 20 de junho de 1984. Estabelece as instruções reguladoras das normas técnicas da cartografia nacional.

EASTMAN, J. R. Guide to GIS and Imaging Processing (2006): IDRISI Andes Manual: Version 15.0. Worcester, MA, Clark Labs of Clark University.

EMPRESA BRASILEIRA DE PESQUISA AGROPECUÁRIA (1999): Sistema brasileiro de classificação de solos. Centro Nacional de Pesquisa de Solos. Brasília.

ESRI Inc. (1998). ArcGIS Desktop: Release 9.3. Redlands, CA: Environmental Systems Research Institute.

ESRI Inc. (2010) ARCMap version 10. Environmental Systems Research Institute Inc. New York.

GAGO, M. (2007): Concepções de passado como expressão de consciência histórica. Currículo sem Fronteiras, v.7, n.1, pp.127-136.

FILET, M.; GRAÇA L., R. da; POLETI, A. E. (2001): A lei de gerenciamento costeiro do Estado de São Paulo e a construção de um instrumento para a ação.. Anais do I Congresso Brasileiro de Pesquisas Ambientais, Santos (São Paulo), v. único. 
FOSTER, G. R., MCCOOL, D. K., RENARD, K. G., MOLDENHAUER, W. C. (1981): Conversion of the universal soil loss equation to SI metric units. Journal of Soil and Water Conservation. November - December. pp 355-359.

GLOBAL LAND COVER FACILITY. LANDSAT TM. Imagem de satélite. Canais 1,2,3,4,5 e 7. Órbita/Ponto: 220/077. Junho de 1993. Disponível em: <http:// www.landcover.org > Acesso em 14/08/2012.

GLOBAL LAND COVER FACILITY. LANDSAT TM. Imagem de satélite. Canais 1,2,3,4,5 e 7. Órbita/Ponto: 219/077. Setembro de 1999. Disponível em: <http:// www.landcover.org > Acesso em 25/02/2013.

GUERRA, A. J. T. (1994): Processos erosivos nas encostas. In: Guerra AJT \& Cunha S (Ed.) Geomorfologia: uma atualização de conceitos e bases. Rio de Janeiro: Bertrand Brasil, Cap. 1, pp 23-50.

GUERRA, A. J. T. \& MENDONÇA, J. K. S. (2004): Erosão dos Solos e a Questão Ambiental. In: Guerra AJT \& Vitt CA (orgs.) Reflexões sobre a Geografia Física no Brasil. Ed. Bertrand Brasil, Rio de Janeiro. pp. 225-251.

GRIGG, N.S. (1996): Water resources management: principles, regulations, and cases. New York, McGraw-Hill Book. 540p.

GUIDICINI, G.; NIEBLE, C. M. (1984): Estabilidade de taludes naturais e de escavação. $2^{\circ}$ edição. Edgard Blücher, 194p. 1984.

HAWBAKER, T.J.; RADELOFF, V.C.; HAMMER, R.B.; CLAYTON, M.K. (2004) Road density and landscape pattern in relation to housing density, land ownership, land cover, and soils. Landscape Ecology, v.20, p.609-625.

INFANTE, J. R.; FORNASARI, F. (1998): Processos de dinâmica superficial. In: OLIVEIRA, A. M.; BRITO, S. N. A. (Ed.) Geologia de engenharia São Paulo: Associação Brasileira de Geologia e Engenharia (ABGE).

IBGE - INSTITUTO BRASILEIRO DE GEOGRAFIA E ESTATÍSTICA (2010) Instituto Brasileiro de Geografia e Estatística, 2010. Disponível em: <http: http://www.ibge.gov.br/home/estatistica/populacao/censo2010/default.shtm>.

Acessado em: jan/2013.

INSTITUTO FLORESTAL (2007) Inventário florestal da vegetação natural do Estado de São Paulo: Regiões Administrativas de São José dos Campos (Litoral), Baixada Santista e Registro / Instituto Florestal; coordenação editorial Francisco J. N. Kronka - São Paulo: Secretaria de Estado do Meio Ambiente : Imprensa Ofi cial do Estado de São Paulo. 140p. : il. 
INPE - Instituto Nacional de Pesquisas Espaciais. LANDSAT TM. Imagem de satélite. Canais 1,2,3,4,5 e 7. Órbita/Ponto: 220/077. Novembro de 2010. Disponível em: <http://www.inpe.br> Acesso em 19/11/2010.

INPE - Instituto Nacional de Pesquisas Espaciais. LANDSAT TM. Imagem de satélite. Canais 1,2,3,4,5 e 7. Órbita/Ponto: 219/077. Setembro de 1987. Disponível em: <http://www.inpe.br> Acesso em 12/04/2011.

INPE - Instituto Nacional de Pesquisas Espaciais. LANDSAT TM. Imagem de satélite. Canais 1,2,3,4,5 e 7. Órbita/Ponto: 219/077. Setembro de 1999. Disponível em: <http://www.inpe.br> Acesso em 24/02/2013.

INPE - Instituto Nacional de Pesquisas Espaciais. LANDSAT TM. Imagem de satélite. Canais 1,2,3,4,5 e 7. Órbita/Ponto: 219/077. Fevereiro de 2010. Disponível em: <http://www.inpe.br> Acesso em 25/02/2013.

INPE - Instituto Nacional de Pesquisas Espaciais. LANDSAT TM. Imagem de satélite. Canais 1,2,3,4,5 e 7. Órbita/Ponto: 220/077. Julho de 1986. Disponível em: <http://www.inpe.br> Acesso em 24/02/2013.

INTERGOVERNMENTAL PANEL ON CLIMATE CHANGE - IPCC. Climate Change 2007: The Physical Science Basis. Contribution of Working Group I to the Fourth Assessment Report of the Intergovernmental Panel on Climate Change, S. Solomon et al., Eds. (Cambridge Univ. Press, Cambridge, 2007). 2007.

INTERGOVERNMENTAL PANEL ON CLIMATE CHANGE - IPCC. Workshop on sea level rise and ice sheet instabilities. 21 - 24 June, 2010. Kuala Lumpur, Malaysia. 2010.

JOLLIFFE I.T. (2002) Principal Component Analysis, Series: Springer Series in Statistics, 2nd ed., Springer, NY, 2002, XXIX, 487 p. 28 illus. ISBN 978-0-38795442-4. 2002.

JURADO, P. F. Análisis de las problemáticas asociadas a la espacialización, evolución y representación de niveles del mar presentes y futuros em Andalucía. Tese de doctorado. Departamento de Geografía Física y A. G. R. Universidad de Sevilla. p. 354. 2011. 
JÚNIOR, D. R. do N., GIANNINI, P. C. F., TANAKA, A. P. B. (2008): Mudanças Morfológicas da Extremidade NE da Ilha Comprida (SP) nos Últimos Dois Séculos. Revista do Instituto de Geociências - USP. São Paulo, v. 8, n. 1, p. 25-39.

LANDIS, J. R., KOCHSOURCE, G. G. (1977) The Measurement of Observer Agreement for Categorical: Biometrics, Vol. 33, No. 1 (Mar., 1977), pp. 159-174.

Lei Federal, n 7875 de 13 de novembro de 1989. Modifica dispositivo do Código Florestal vigente (Lei ${ }^{\circ}$ 4.771, de 15 de setembro de 1965).

KULMANN, D. (2004): Estudo Morfométrico da Bacia Hidrográfica do Arroio JaguariMirim, RS. Trabalho de Graduação (Graduação em Geografia) - Universidade Federal de Santa Maria. P 71.

LEPSCH, I. F.; PRADO, H.; MENK, J. R. F.; SAKAI, E.; RIZZO, L. T. B. (1999): Levantamento de reconhecimento com detalhes dos solos da região do Ribeira de Iguape no Estado de São Paulo. Governo do Estado de São Paulo, Secretaria de Agricultura e Abastecimento, Instituto Agronômico. Mapa na escala 1:250.000.

LIMA, T. C.; TEIXEIRA, D. A.; HERCUlANO, R. N.; NOGUEIRA, S. M. A. (2010): El uso de SIG en la zonificación de las áreas protegidas -APA-ITAÚNA/BRASIL-. Un caso de estudio. En: Ojeda, J., Pita, M.F. y Vallejo, I. (Eds.), Tecnologías de la Información Geográfica: La Información Geográfica al servicio de los ciudadanos. Secretariado de Publicaciones de la Universidad de Sevilla. Sevilla. Pp. 889-904. ISBN: 978-84-4721294-1.

LIOTTE, S. V. (2000): Utilização de técnicas de geoprocessamento para apoio ao planejamento físico-territorial do município de Pariquera-Açu. Dissertação (mestrado) Instituto de Geociências, Universidade de São Paulo, São Paulo. 170 p.

LIU, X., SHIGE, W., XINBAO, Z. (1992): Influence of Geologic Factors on Landslides Zhaotong, Yunnan Province, China. Environ Geol Water Sci Vol. 19, No. 1, PP. 17-20.

LOBO, M. L. C.; PCBAP (2003): Plano de conservação da bacia do alto Paraguai. Centro Integrado de Estudos em Geoprocessamento, Universidade Federal do Paraná. Acessado em 18 de outubro de 2008. Disponível em: http://www.cieg.ufpr.br/baciaaltopguai.ciegufpr.pdf.

MACEDO, A.B. - coord. (2007): Relatório de Situação dos Recursos Hídricos da UGRHI-11. Registro. COMITÊ DA BACIA HIDROGRÁFICA DO VALE DO RIBEIRA DE IGUAPE E LITORAL SUL/FEHIDRO/FUNDESPA. .Disponível em CD-ROM e na Internet: http://geolig.igc.usp.br/geoproc/rs_ugrhi_rb/index.php. 
MACEDO, A.B. - coord. (2008): Sistema de Informações da Bacia Hidrográfica do Ribeira de Iguape e Litoral Sul, versão 2.3.1. Registro. COMITÊ DA BACIA HIDROGRÁFICA DO VALE DO RIBEIRA DE IGUAPE E LITORAL SUL/FEHIDRO/FUNDESPA. Disponível em CD-ROM e na Internet: http://geolig.igc.usp.br/geoproc/sigrb/index.php.

MACEDO, A.B. - coord. (2009):Relatório de Situação dos Recursos Hídricos da UGRHI-11. Registro. COMITÊ DA BACIA HIDROGRÁFICA DO VALE DO RIBEIRA DE IGUAPE E LITORAL SUL/FEHIDRO/FUNDESPA. Disponível em CD-ROM e na Internet:

http://geolig.igc.usp.br/geoproc/rs_ugrhi_rb/index.php

MACHADO, R. E.; VETTORAZZI, C. A.; XAVIER, A. C. (2003): Simulação de cenários alternativos de uso da terra de uma microbacia utilizando técnicas de modelagem e geoprocessamento. R. Bras. Ci. Solo, 27:727-733, 2003.

MICROSOFT Project for Windows 2007: project planning software. [S.1.]: Microsoft Corporation, 2007. Conjunto de programas. $1 \mathrm{CD}-\mathrm{ROM}$.

MINISTÉRIO DO MEIO AMBIENTE - MMA (2006): Diretrizes Metodológicas para o Zoneamento Ecológico-Econômico do Brasil. Parte 2. 29 p. Disponível em: http://www.mma.gov.br/sitio/index.php?ido=conteudo.monta\&idEstrutura=28\&idConte $\mathrm{udo}=8219$.

MIRANDA, E. E., COUTINHO, A. C., GUIMARÃES, M, VAZ, M. (2008): O zoneamento Ecológico Econômico do Estado do Maranhão. Available at: <http://www.cnpm.embrapa.br/publica/download/newsdownload/artigos_resumos\%20a nais\%20eventos/rpc_gisbrasil02_zeema_mir.pdf>. Accessed on 18th October 2008.

MONGUILHOTT, M (2008): Estudo de áreas suscetíveis a movimentos de massa na rodovia RS/486 - Rota do Sol. / Michele Monguilhott. - Porto Alegre : UFRGS/CEPSRM. p 115.

NEARING, M. A., FOSTER, G. R., LANE, L. J., FINKNER, S. C. (1989): A process-based soil erosion model for USDA Water Erosion Prediction Project technology. Trans. ASAE 32(5): 1587-1593.

NUMMER, A. V. (2003): Parâmetros geológicos-geotécnicos controladores dos movimentos de massa na Rota do Sol/RS/486 - Itati, RS/Andréa Nummer - Porto Alegre:PPGEC/UFRGS.

OLIVEIRA, J. B. de. (2005): Pedologia aplicada. FEALQ: Piracicaba, 2 ed. 574p. 
OLIVEIRA, J. B. de. (1999): Solos do Estado de São Paulo: descrição das classes registradas no mapa pedológico, por João Bertoldo de Oliveira. Campinas, Instituto Agronômico, 112 p.

PARANHOS, F. A. C., FIORI, A. P., DISPERATI, L., LUCCHESI, C., CIALI, A., LASTORIA, G. (2003): Avaliação Multitemporal das Perdas dos Solos na Bacia do Rio Taquarizinho através de SIG. Boletim Paranaense de Geociências. Curitiba, v. 52, pp 4959.

PENTEADO, M. M (1983): Fundamentos de Geomorfologia. Rio de Janeiro: IBGE.

PARKER, D.; MANSON, S.; JANSSEN, M.; HOFFMANN, M.; DEADMAN, P. (2003): Multi-agents systems for the simulation of land-use and land-cover change. Annals of the Association of American Geographers, 93 (2): 314-337.

PERMANENT SERVICE FOR MEAN SEA LEVEL. Dados do marégrafo de Cananéia (1954 - 2006). Acessado em 15 de março de 2012. Disponível em: http://www.psmsl.org/.

PESSOA, M.C.P.Y.; LUCHIARI, A.J.; FERNANDES, E.N., LIMA, M. A. (1997): Principais modelos matemáticos e simuladores utilizados para análise de impactos ambientais das atividades agrícolas. Jaguariúna, EMBRAPA/CNPMA, 83p. (EMBRAPA. CNPMA. Documentos, 8).

PFEFFER, W. T., HARPER, J. T., O'NEEL, S. Kinematic Constraints on Glacier Contributions to 21st-Century Sea-Level Rise. Science Express. Vol. 321 no. 5894 pp. 1340-1343. 2008.

PONÇANO, W.L.; CARNEIRO, C.D.R.; BISTRICHI, C.A.; ALMEIDA, .F.M.; PRANDINI, F.L. (1981): Mapa Geomorfológico do Estado de São Paulo, São Paulo, IPT. v. 1. (Monografia 5).

PRBMA - PORTAL DA RESERVA DA BIOSFERA DA MATA ATLÂNTICA. Flora e Ecorregião da Serra do Mar. Acessado em: mai/2013. Disponível em: <http: http://www.rbma.org.br/anuario/mata_06_smar_asp_bio_flora.asp>.

RAHMSTORF, S. A Semi-Empirical Approach to Projecting Future Sea-Level Rise. Science Express. Vol. 315 no. 5810 pp. 368-370. 2006.

Research Systems International (2010). ENVI - The environment for Visualizing Images. Version 4.7.

RISSE, L. M., NEARING, M. A., NICKS, A. D., LAFLEN, J. M. (1993): Assessment of error in the universal soil loss equation. Soil Science Society of America Journal, Madison, v.57, n.3, p.825-833. 
RIZZINI, C.T. (1963): Nota prévia sobre a divisão fitogeográfica do Brasil. Rev. Bras. Geogr., 25(1):1-64, Rio de Janeiro.

ROSS, J. L. S. (1995): Plano de conservação da bacia do Alto Paraguai. Ministério do Meio Ambiente. Brasília.

ROSS, J. L. S. (2006): Ecogeografia do Brasil : subsídios para planejamento ambiental. São Paulo : Oficina de Textos, 208p.

ROSS, J. L. S. (2002): A morfogênese da bacia do rio Ribeira de Iguape e os sistemas ambientais. GEOUSP. São Paulo, n. 12.

SÃO PAULO (Estado). Secretaria de Agricultura e Abastecimento. Coordenadoria de Assistência Técnica Integral. Instituto de Economia Agrícola. Levantamento censitário de unidades de produção agrícola do Estado de São Paulo - LUPA 2007/2008. São Paulo: SAA/CATI/IEA, 2008. Disponível em: <http://www.cati.sp.gov.br/projetolupa>. Acesso em: 10/02/2013.

SERVIÇO GEOLÓGICO DO ESTADO DO RIO DE JANEIRO. Departamento de Recursos Minerais (2011) Megadesastre da Serra (jan 2011). Available at:

http://www.drm.rj.gov.br/index.php/component/content/article/31-home/215-servicogeologico-do-estado- do-rio-de-janeiro-divulga-diagnostico-sobre-o-mega-desastre-naserra-fluminense. Accessed on 18th December 2011.

SIDLE, R. C. (1985): Factors influencing the stability of slopes. In: Proceedings of a Workshop on Stability: Problems and Solution in Forest Management. USDA Forest Service Gen. Tech. Rep. PNW-180. Portland, pp 17-25.

SILVA, A. C. N. (2002): Geoprocessamento e sensoriamento remoto como apoio ao planejamento territorial do município de Iporanga, SP. Dissertação (mestrado) Instituto de Geociências, Universidade de São Paulo, São Paulo.

STEIN, D. P., DONZELLI, P. L., GIMENEZ, F. A., PONÇANO, E. L., LOMBARDI, N. F. (1987): Potencial de Erosão Laminar, Natural e Antrópica na Bacia do PeixeParapanema. In: Simpósio Nacional de Controle de Erosão, 4., Anais do Simpósio Nacional de Controle de Erosão. Marília, São Paulo, ABGE/DAEE, pp105-135.

TERRA, T. N. (2010): Efeitos cumulativos e a construção de cenários em paisagens legalmente protegidas. Campinas: Faculdade de Engenharia Civil - UNICAMP. 114p. Dissertação (Mestrado) - Faculdade de Engenharia Civil, Arquitetura e Urbanismo, UNICAMP. 
THEODOROVICZ, A.; THEODOROVICZ , A.M.G. (2007) Atlas geoambiental: subsídios ao planejamento territorial e à gestão ambiental da bacia hidrográfica do rio Ribeira de Iguape. 2 ed. revisado. São Paulo: CPRM.

TITUS, J. G.; NARAYANAN, V. K. The probability of sea level rise. Library of Congress Cataloging-in-Publication Data. 1998.

TIWARI, A. K., RISSE, L. M., NEARING, M. A. (2000): Evaluation of WEPP and its comparison with USLE and RUSLE. Transactions of the American Society of Agricultural Engineers, St.Joseph, v.5, n.43, p.1.129-1.135.

UBIERNA, S. G., MARTÍNEZ, M. A. C., IBARRA, J. M. N. (2009): USLE, RUSLE and WEPP models used in mining restored hillslopes. Uso de geotecnologias para mapeamento de áreas de riscos. Murcia - Spain. In: Congresos Científicos de la Universidad de Murcia, Congreso Internacional sobre Desertificación, 2009. Advances in studies on desertification : contributions to the International Conference on Desertification, pp 263-266.

UNIVERSIDADE FEDERAL DE SANTA CATARINA. CENTRO UNIVERSITÁRIO DE ESTUDOS E PESQUISAS SOBRE DESASTRES (2011): Atlas brasileiro de desastres naturais 1991 a 2011: volume Santa Catarina . Centro Universitário de Estudos e Pesquisas sobre Desastres: CEPED UFSC. p 80.

VALDAMERI, R. M. (1997): Elaboração do mapa de capacidade de uso da terra através de técnicas de sensoriamento remoto e geoprocessamento. p 65.

VALENTE, R.O.A.; VETTORAZZI, C.A. (2008): Definition of priority areas for forest conservation through the ordered weighted averaging method. Forest Ecology and Management, v.256, n.6, p.1408-1417.

VIEIRA, E. H. A. (2010): Conservação ambiental em cenários de uso: medidas de mudanças, heterogeneidade e valoração da paisagem. Tese (Doutorado). Campinas: Faculdade deEngenharia Civil, Arquitetura e Urbanismo - UNICAMP. 178p.

WISCHMEIER, W. H. \& SMITH, D. D. (1958): Rainfall Energy and its Relationship to Soil Loss. Amer. Geoph. Union, Transactions, Washington, pp 285-291.

WISCHMEIER, W. H. \& SMITH, D. D. (1978): Predicting rainfall erosion losses. A guide to conservation planning. USDA Handbook N. 537. Washington. p 57.

ZÚJAR, J. O., SANCHEZ, E., FERNANDEZ-PALACIOS, A., MOREIRA, J.M. (1995): Study of the dynamics of estuarine and coastal waters using remote sensing: the TintoOdiel estuary, SW Spain. Journal of Coastal Conservation 1: 109-118. 
ZÚJAR, J. O. (2000): Método para el cálculo de la erisión costera. Revision, tendencias y propuesta. Boletim de la A. G. E., n 30, págs. 103-118.

ZÚJAR, J. O., LAMA, A. V. (2006): Evolución del suelo urbano/alterado en el litoral de Andalucía, GeoFocus (Artículos), no 7, p. 73-99. ISSN: 1578-5157.

ZÚJAR, J. O., FRANCOSO, J. A., J. I., MARTÍN CAJARAVILLE, D., JURADO, P. F. El uso de las TIG para el cálculo del indice de vulnerabilidad costera (CVI) ante una potencial subida del nivel del mar en la costa andaluza (España). GeoFocus (Artículos), no 9, p. 83-100. ISSN: 1578-5157. 2009.

ZUQUETTE, L. V., GANDOLFI, N. (2004): Cartografia Geotécnica. Oficina de Textos. São Paulo. p 190 